Prepared in cooperation with the

West Virginia Department of Health and Human Resources, Office of Environmental Health Services and the West Virginia Department of Environmental Protection, Division of Water and Waste Management

\title{
Groundwater Quality and Geochemistry of West Virginia's Southern Coal Fields
}

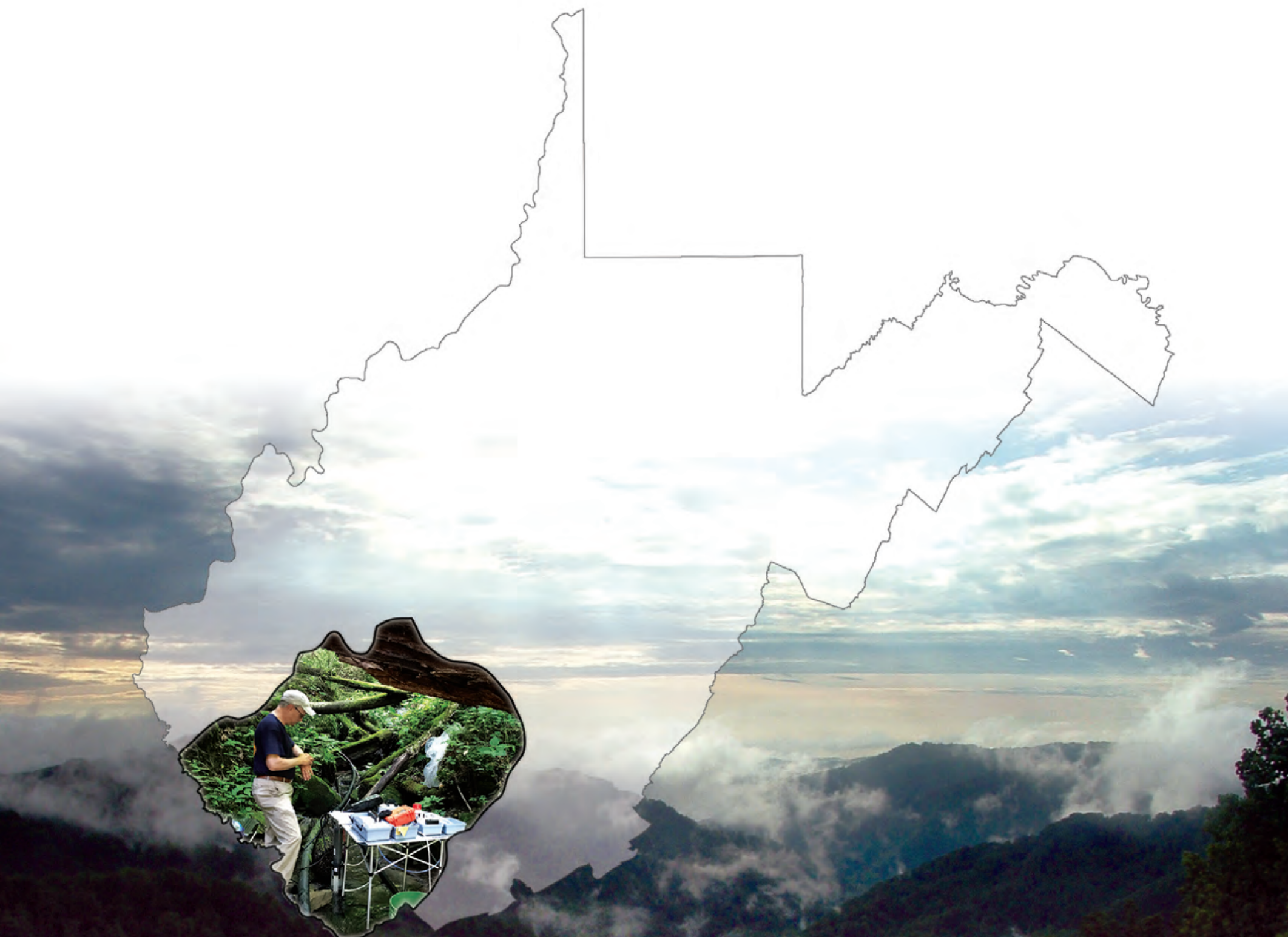

Scientific Investigations Report 2019-5059

Version 1.1, March 2020

U.S. Department of the Interior U.S. Geological Survey 
Cover. Overview of the Elkhorn Creek Valley, McDowell County, West Virginia. Inset shows worker monitoring field parameters at a mine outfall discharge from the Pocahontas Number 3 coal seam near Ashland, Mcdowell County, West Virginia. Photographs by Mark D. Kozar, U.S. Geological Survey. 


\section{Ground water Quality and Geochemistry of West Virginia's Southern Coal Fields}

By Mark D. Kozar, Mitchell A. McAdoo, and Karl B. Haase

Prepared in cooperation with the

West Virginia Department of Health and Human Resources,

Office of Environmental Health Services and the

West Virginia Department of Environmental Protection,

Division of Water and Waste Management

Scientific Investigations Report 2019-5059

Version 1.1, March 2020 


\title{
U.S. Department of the Interior DAVID BERNHARDT, Secretary
}

\section{U.S. Geological Survey James F. Reilly II, Director}

\author{
U.S. Geological Survey, Reston, Virginia: 2020 \\ First release: 2020 \\ Revised: March 2020 (ver 1.1)
}

\begin{abstract}
For more information on the USGS - the Federal source for science about the Earth, its natural and living resources, natural hazards, and the environment-visit https://www.usgs.gov or call 1-888-ASK-USGS.

For an overview of USGS information products, including maps, imagery, and publications, visit https://store.usgs.gov.
\end{abstract}

Any use of trade, firm, or product names is for descriptive purposes only and does not imply endorsement by the U.S. Government.

Although this information product, for the most part, is in the public domain, it also may contain copyrighted materials as noted in the text. Permission to reproduce copyrighted items must be secured from the copyright owner.

Suggested citation:

Kozar, M.D., McAdoo, M.A., and Haase, K.B., 2020, Groundwater quality and geochemistry of West Virginia's southern coal fields (ver. 1.1, March 2020): U.S. Geological Survey Scientific Investigations Report 2019-5059, 78 p., https://doi.org/10.3133/sir20195059. 


\section{Acknowledgments}

The U.S. Geological Survey (USGS) would like to acknowledge William Toomey and Brian Carr of the West Virginia Department of Health and Human Resources, and Scott Rodeheaver of the West Virginia Department of Environmental Protection for their assistance in providing support to bring this study to fruition. Todd Cooper of the West Virginia Department of Environmental Protection and Rick Shaver of the West Virginia Department of Health and Human Resources are also acknowledged for assisting with field reconnaissance of sampling sites, assisting with sampling of the sites discussed in this report, and providing daily assistance with transporting samples for shipment to the U.S. Geological Survey National Water Quality Laboratory in Denver, Colorado. Finally, the USGS would like to acknowledge the residents of southern West Virginia who allowed access to their wells for sampling. This study would not have been possible without the assistance of the aforementioned individuals. 


\section{Contents}

Acknowledgments .......................................................................................................................ii

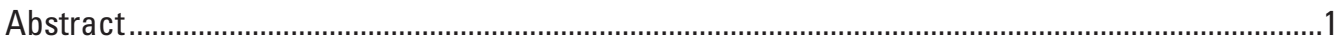

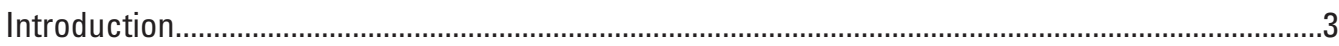

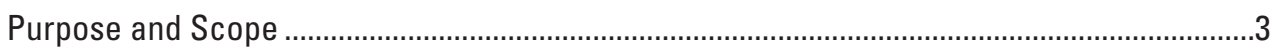

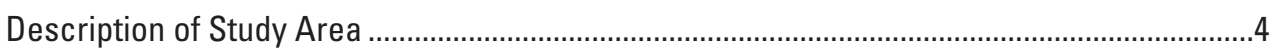

Hydrogeologic Setting and Groundwater Flow ..........................................................

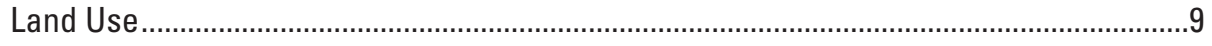

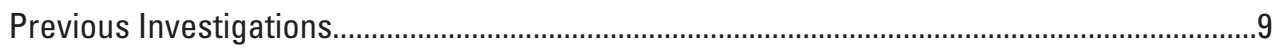

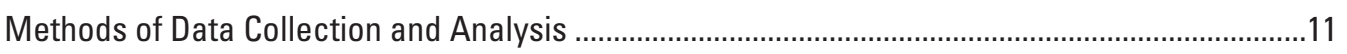

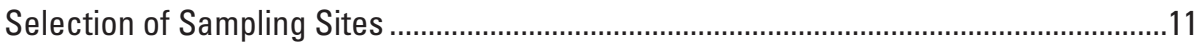

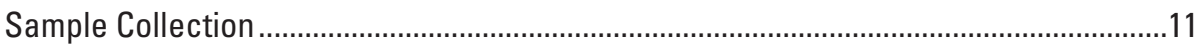

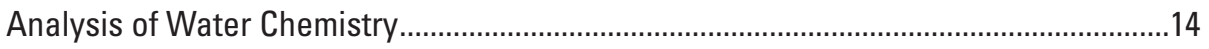

Analysis of Dissolved Hydrocarbons...........................................................................

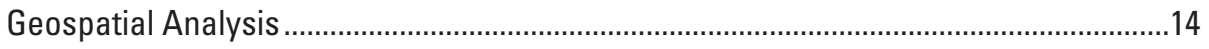

Quality Assurance and Quality Control .....................................................................14

Statistical and Graphical Analysis ............................................................................15

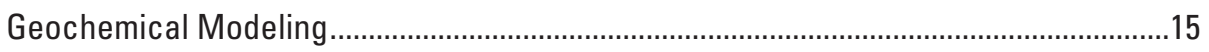

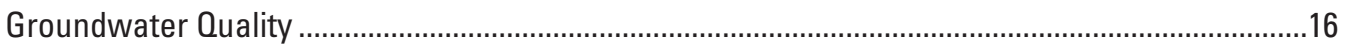

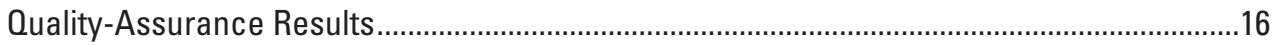

Groundwater Quality in Relation to Drinking-Water Standards...........................................19

Field Measurements of pH, Alkalinity, Turbidity, Specific Conductance,

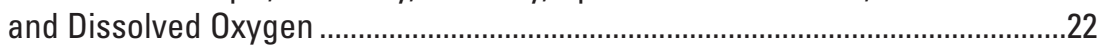

Corrosivity and Potential for Galvanic Corrosion ...........................................................25

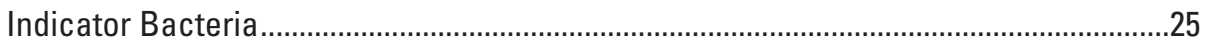

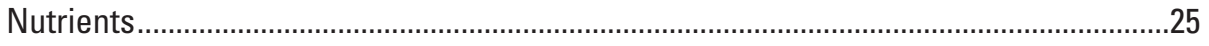

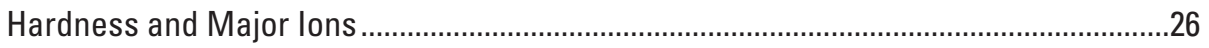

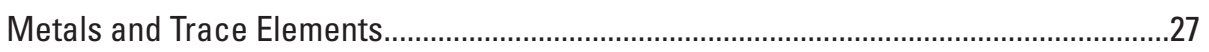

Dissolved Combustible Gases .........................................................................................27

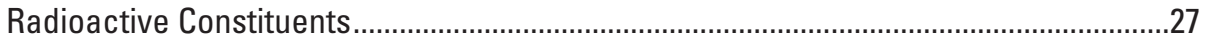

Groundwater Quality in Relation to Geologic Formation and Type of Mining........................28

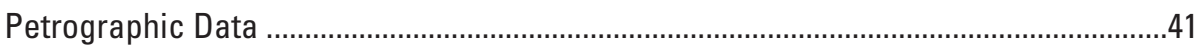

Major Ions and Total Dissolved Solids (TDS) ............................................................ 44

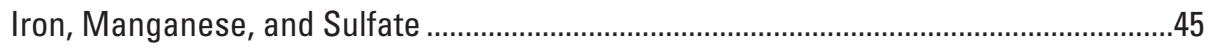

Constituents of Brines and Sandstones......................................................................4

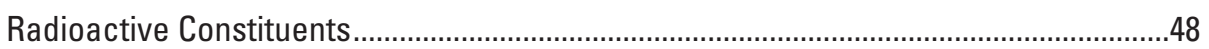

Groundwater Quality in Relation to Site Type and Topographic Setting ..............................49

Groundwater Quality in Relation to Well Construction............................................................50

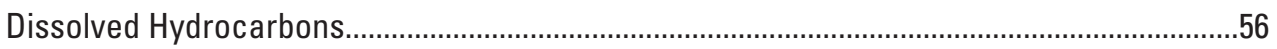

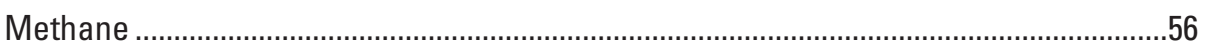

Ethane and Other Hydrocarbons.................................................................................

Dissolved Hydrocarbon Composition and Origin..........................................................57

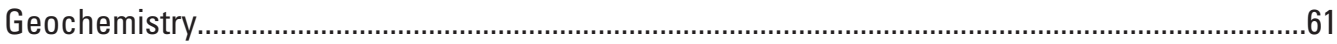

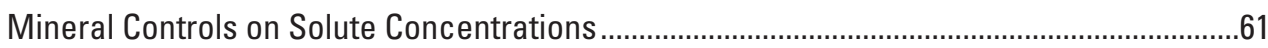

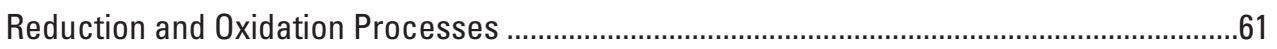




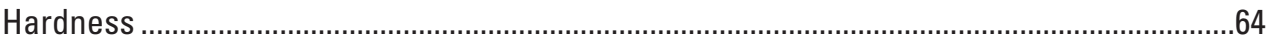

$\mathrm{pH}$

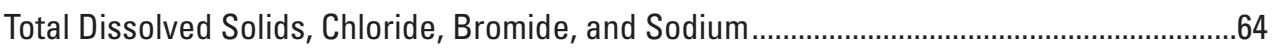

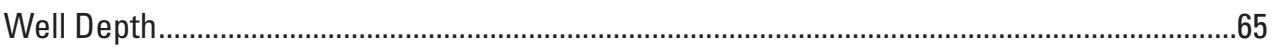

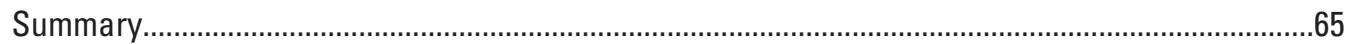

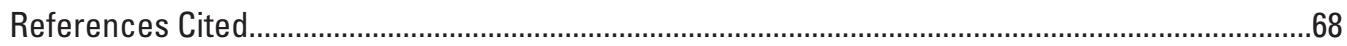

Appendix 1. Correlation matrix showing Spearman correlation coefficients of statistical significance at a confidence interval of 99.9 percent for 46 variables, including 41 chemical constituents and 5 principal component analysis scores

\section{Figures}

1. Map showing location of study area and distribution of sites sampled ...........................5

2. Map showing geology of the West Virginia southern coal-field province and location of groundwater-quality sampling sites.

3. Conceptual models of groundwater flow, $A$, in an unmined Appalachian Plateaus fractured-bedrock aquifer, including apparent age of groundwater and, $B$, in a fractured-bedrock aquifer modified by creation of anthropogenic secondarypermeability features from mine entries within a room and pillar type underground coal mine.

4. Boxplots showing distribution of well yields with respect to topographic setting, based on analyses of U.S. Geological Survey National Water Information System data for 777 wells in 13 counties in the West Virginia southern coal-field province ........8

5. Map showing distribution of sites sampled with respect to mining extent and type .....12

6. Boxplots showing distribution of concentrations of constituents that commonly exceed one or more of the drinking-water standards for 10 percent or more of the sites sampled

7A. Trilinear diagram showing major-ion composition in groundwater samples for 60 sites in the West Virginia southern coal-field province grouped by geologic formation

7B. Trilinear diagram showing major-ion composition in groundwater samples for 60 sites in the West Virginia southern coal-field province grouped by predominance of the type of mining

7C. Trilinear diagram showing major-ion composition in groundwater samples for 60 sites in the West Virginia southern coal-field province grouped by sample $\mathrm{pH}$.

7D. Trilinear diagram showing major-ion composition in groundwater samples for 60 sites in the West Virginia southern coal-field province grouped by topographic setting

8. Boxplots showing distribution of major-ion concentrations responsible for most total dissolved solids in groundwater samples for 60 sites sampled in the West Virginia southern coal-field province, grouped by geologic formation.

9. Boxplots showing distribution of iron, manganese, sulfate, dissolved oxygen, and field $\mathrm{pH}$ in groundwater samples for 60 sites in the West Virginia southern coal-field province, grouped by geologic formation.

10. Boxplots showing distribution of major-ion concentrations, commonly found in brine or road salt, in groundwater samples for 60 sites in the West Virginia southern coal-field province, grouped by geologic formation. 
11. Boxplots showing uranium and radon concentrations in groundwater samples for 60 sites in the West Virginia southern coal-field province, grouped by geologic formation

12. Boxplots showing constituents related to topographic setting in groundwater samples for 60 sites in the West Virginia southern coal-field province

13. Boxplots showing distribution of $A$, sulfate and selenium with respect to dissolved oxygen and site type, either mine outfalls or wells, and $B$, barium, chloride, iron, manganese, and radon with respect to site type, either mine outfalls or wells, in groundwater samples for 60 sites in the West Virginia southern coal-field province.

14. Decadal histogram of dissolved methane concentrations in groundwater samples from the West Virginia southern coal-field province.

15. Graph showing relation between methane concentration and the methane/ethane ratio in groundwater samples from the West Virginia southern coal-field province......58

16. Graph showing dissolved methane concentration and the methane/ethane ratio, with a color scale of the enrichment gradient of isobutane over $n$-butane for samples with high methane and low ethane/methane ratio

17. Graph showing dissolved methane concentration and the methane/ethane ratio, with a color scale of the enrichment gradient of isopentane over $n$-pentane for samples with high methane and low ethane/methane ratio

18. Graph showing ratios of methane/ethane and ethane/propane in natural gas indicative of origin and processes that have acted on the sample

19. Graph showing methane concentration versus chloride to bromide mass ratio and chloride concentration

20. Graphs showing saturation indices for selected mineral phases computed using the geochemical model, PHREEOC.

21. Graph showing chloride to bromide mass ratio and chloride concentration for 60 sites in the West Virginia southern coal-field province 


\section{Tables}

1. Constituents and reporting limits for major ions, metals, trace elements, nutrients, radon-222, fecal indicator bacteria, and dissolved hydrocarbons analyzed in groundwater samples collected from sites in the West Virginia southern coal-field province.

2. U.S. Geological Survey station numbers, station names, site type, dates when wells and mine outfalls were sampled, coal-field region, and well-construction data for sites sampled in the West Virginia southern coal-field province...

$3 A$. Summary table of U.S. Environmental Protection Agency drinking-water standards, U.S. Geological Survey health-based screening levels, and U.S. Office of Surface Mining Reclamation and Enforcement level of concern and immediate action level for methane in groundwater.

$3 B$. Summary table of U.S. Environmental Protection Agency drinking-water standards, U.S. Geological Survey health-based screening levels, and U.S. Office of Surface Mining Reclamation and Enforcement level of concern and immediate action level for methane in groundwater, applied to water-quality data from this report..........21

4. Statistical summary of analytical data for selected constituents analyzed in water samples from the 60 sites sampled in the West Virginia southern coal-field province.

5. Comparison of $p$-values from Wilcoxon signed ranked tests of statistical significance for site types, topographic settings, dominant types of mining, and geologic formations in the West Virginia southern coal-field province..

$6 A$. Statistical summary of analytical results for groundwater samples for 34 sites from the West Virginia southern coal-field province, differentiated by the predominance of the type of mining, for the western surface-mined-dominated part of the study area.

$6 B$. Statistical summary of analytical results for groundwater samples for 26 sites from the West Virginia southern coal-field province, differentiated by the predominance of the type of mining, for the eastern underground-mineddominated part of the study area.

7A. Statistical summary of analytical results for groundwater samples for 10 sites from the West Virginia southern coal-field province, differentiated by geologic formation for the Pocahontas and Bluestone and Princeton Formations.

7B. Statistical summary of analytical results for groundwater samples for 16 sites from the West Virginia southern coal-field province, differentiated by geologic formation for the New River Formation...

7C. Statistical summary of analytical results for groundwater samples for 34 sites from the West Virginia southern coal-field province, differentiated by geologic formation for the Kanawha and Allegheny Formations.

$8 A$. Statistical summary of analytical results for groundwater samples from the West Virginia southern coal-field province for 14 mine outfalls sampled in the study area

$8 B$. Statistical summary of analytical results for groundwater samples from the West Virginia southern coal-field province for 46 wells sampled in the study area.......54

9. Principal component analysis showing distribution of eigenvector loadings and significant Spearman correlation coefficients for variables not included in the principal component analysis model. 


\section{Conversion Factors}

U.S. customary units to International System of Units

\begin{tabular}{|c|c|c|}
\hline Multiply & By & To obtain \\
\hline \multicolumn{3}{|c|}{ Length } \\
\hline inch (in.) & 2.54 & centimeter $(\mathrm{cm})$ \\
\hline inch (in.) & 25.4 & millimeter (mm) \\
\hline foot $(\mathrm{ft})$ & 0.3048 & meter $(\mathrm{m})$ \\
\hline mile (mi) & 1.609 & kilometer $(\mathrm{km})$ \\
\hline \multicolumn{3}{|c|}{ Area } \\
\hline square mile $\left(\mathrm{mi}^{2}\right)$ & 259.0 & hectare (ha) \\
\hline square mile $\left(\mathrm{mi}^{2}\right)$ & 2.590 & square kilometer $\left(\mathrm{km}^{2}\right)$ \\
\hline \multicolumn{3}{|c|}{ Volume } \\
\hline gallon (gal) & 3.785 & liter (L) \\
\hline gallon (gal) & 0.003785 & cubic meter $\left(\mathrm{m}^{3}\right)$ \\
\hline gallon (gal) & 3.785 & cubic decimeter $\left(\mathrm{dm}^{3}\right)$ \\
\hline million gallons (Mgal) & 3,785 & cubic meter $\left(\mathrm{m}^{3}\right)$ \\
\hline \multicolumn{3}{|c|}{ Flow rate } \\
\hline foot per second (ft/s) & 0.3048 & meter per second $(\mathrm{m} / \mathrm{s})$ \\
\hline gallon per minute (gal/min) & 0.06309 & liter per second $(\mathrm{L} / \mathrm{s})$ \\
\hline gallon per day (gal/d) & 0.003785 & cubic meter per day $\left(\mathrm{m}^{3} / \mathrm{d}\right)$ \\
\hline inch per year (in/yr) & 25.4 & millimeter per year (mm/yr) \\
\hline million gallons per day $(\mathrm{Mgal} / \mathrm{d})$ & 0.04381 & cubic meter per second $\left(\mathrm{m}^{3} / \mathrm{s}\right)$ \\
\hline \multicolumn{3}{|c|}{ Mass } \\
\hline ounce, avoirdupois (oz) & 28.35 & $\operatorname{gram}(\mathrm{g})$ \\
\hline pound, avoirdupois (lb) & 0.4536 & kilogram (kg) \\
\hline \multicolumn{3}{|c|}{ Pressure } \\
\hline inch of mercury at $60^{\circ} \mathrm{F}$ (in $\mathrm{Hg}$ ) & 3.377 & kilopascal $(\mathrm{kPa})$ \\
\hline \multicolumn{3}{|c|}{ Radioactivity } \\
\hline picocurie per liter (pCi/L) & 0.037 & becquerel per liter $(\mathrm{Bq} / \mathrm{L})$ \\
\hline \multicolumn{3}{|c|}{ Hydraulic conductivity } \\
\hline foot per day (ft/d) & 0.3048 & meter per day $(\mathrm{m} / \mathrm{d})$ \\
\hline
\end{tabular}

Temperature in degrees Celsius $\left({ }^{\circ} \mathrm{C}\right)$ may be converted to degrees Fahrenheit $\left({ }^{\circ} \mathrm{F}\right)$ as follows:

$$
{ }^{\circ} \mathrm{F}=\left(1.8 \times{ }^{\circ} \mathrm{C}\right)+32 .
$$

Temperature in degrees Fahrenheit $\left({ }^{\circ} \mathrm{F}\right)$ may be converted to degrees Celsius $\left({ }^{\circ} \mathrm{C}\right)$ as follows:

$$
{ }^{\circ} \mathrm{C}=\left({ }^{\circ} \mathrm{F}-32\right) / 1.8 .
$$




\section{Datum}

Vertical coordinate information is referenced to the North American Vertical Datum of 1988 (NAVD 88).

Horizontal coordinate information is referenced to the North American Datum of 1983 (NAD 83).

Elevation, as used in this report, refers to distance above the vertical datum.

\section{Supplemental Information}

Specific conductance is given in microsiemens per centimeter at 25 degrees Celsius $\left(\mu \mathrm{S} / \mathrm{cm}\right.$ at $\left.25^{\circ} \mathrm{C}\right)$.

Concentrations of chemical constituents in water are given in either milligrams per liter $(\mathrm{mg} / \mathrm{L})$, micrograms per liter ( $\mu \mathrm{g} / \mathrm{L})$, or milligrams per kilogram $(\mathrm{mg} / \mathrm{kg})$.

Concentrations of dissolved hydrocarbons within this report are given in milligrams per kilogram $(\mathrm{mg} / \mathrm{kg})$, which for freshwater is equivalent to milligrams per liter $(\mathrm{mg} / \mathrm{L})$.

Activities for radioactive constituents in water are given in picocuries per liter ( $\mathrm{pCi} / \mathrm{L})$.

Results for measurements of stable isotopes of an element (with symbol E) in water, solids, and dissolved constituents commonly are expressed as the relative difference in the ratio of the number of the less abundant isotope $(\delta)$ to the number of the more abundant isotope of a sample with respect to a measurement standard.

NOTE TO USGS USERS: Use of hectare (ha) as an alternative name for square hectometer $\left(\mathrm{hm}^{2}\right)$ is restricted to the measurement of small land or water areas. Use of liter (L) as a special name for cubic decimeter $\left(\mathrm{dm}^{3}\right)$ is restricted to the measurement of liquids and gases. No prefix other than milli should be used with liter. Metric ton (t) as a name for megagram (Mg) should be restricted to commercial usage, and no prefixes should be used with it.

\section{Abbreviations}

$\begin{array}{ll}\text { DOD } & \text { U.S. Department of Defense } \\ \text { AED } & \text { atomic emission detector } \\ \text { AMCL } & \text { alternate maximum contaminant level } \\ \text { ANFO } & \text { ammonium nitrate fuel oil } \\ \text { CDC } & \text { Centers for Disease Control and Prevention } \\ \text { DWEL } & \text { drinking water equivalent level } \\ \text { CPVC } & \text { chlorinated polyvinyl chloride } \\ \text { CSMR } & \text { chloride sulfate molar ratio } \\ \text { DWWM } & \text { Division of Water and Waste Management } \\ \text { EPA } & \text { U.S. Environmental Protection Agency } \\ \text { FID } & \text { flame ionization detector }\end{array}$




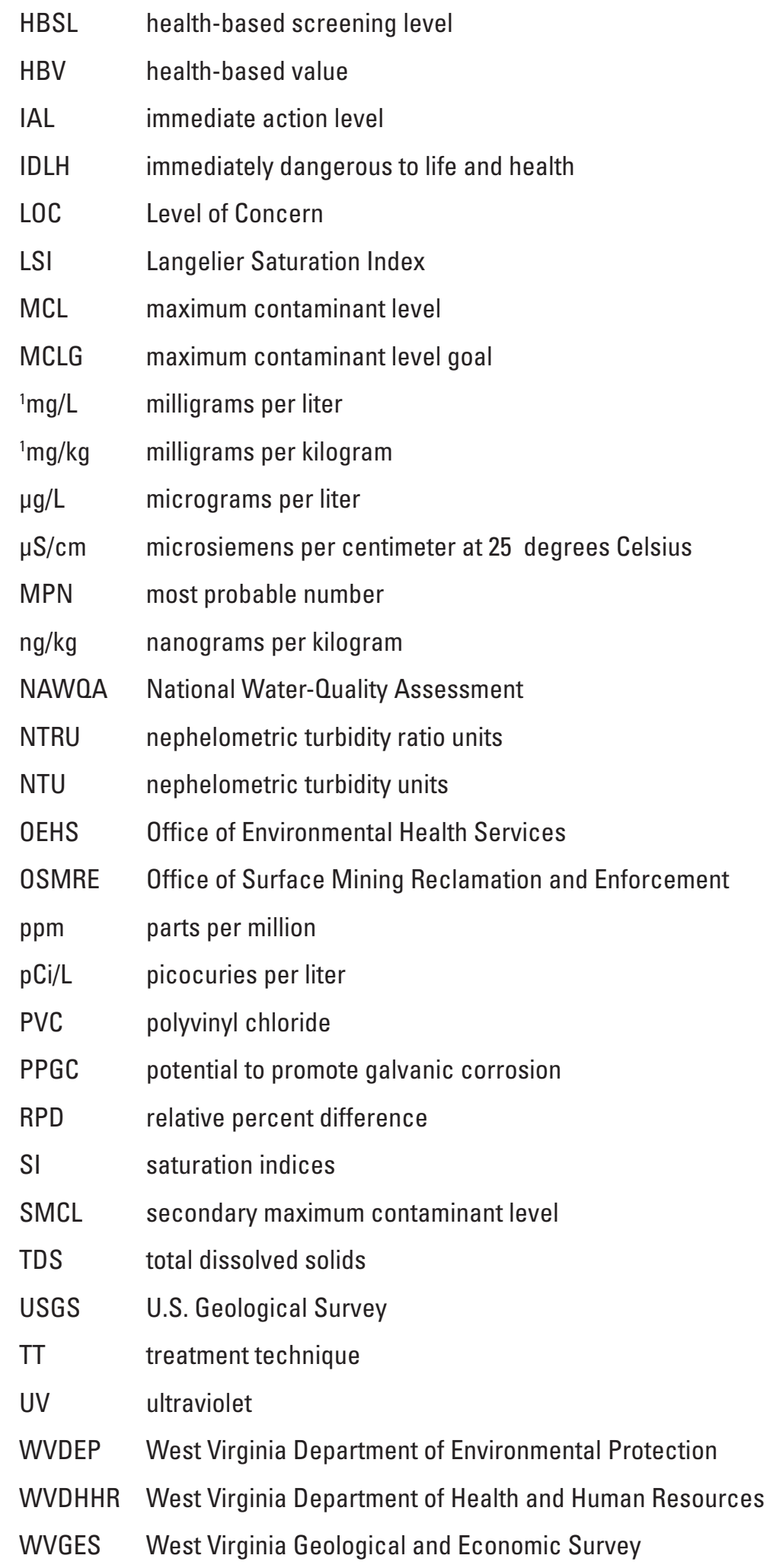

${ }^{1} \mathrm{mg} / \mathrm{kg}$ and $\mathrm{mg} / \mathrm{L}$ are equivalent for water with a density of 1.0 , such as normal fresh groundwater. 


\title{
Ground water Quality and Geochemistry of West Virginia's Southern Coal Fields
}

\author{
By Mark D. Kozar ${ }^{1}$, Mitchell A. McAdoo' ${ }^{1}$ Karl B. Haase²
}

\section{Abstract}

Coal mining has been the dominant industry and land use in West Virginia's southern coal fields since the mid-1800s. Mortality rates for a variety of serious chronic conditions, such as diabetes, heart disease, and some forms of cancer in Appalachian coal mining regions, are higher than in areas lacking substantial coal mining activity within the Appalachian Region or elsewhere in the United States. Causes of the increased mortality and morbidity are not clear, but poor diet, high rates of smoking, socioeconomic factors, and the quality of groundwater used by area residents are all possible contributing factors. This study was conducted by the U.S. Geological Survey in cooperation with the West Virginia Department of Health and Human Resources and the West Virginia Department of Environmental Protection, with grant support from the Centers for Disease Control and Prevention (CDC) to assess the quality of groundwater in southern West Virginia. The data from this assessment of groundwater quality may be used by the $\mathrm{CDC}$ and other agencies to potentially investigate the role or lack thereof of groundwater quality with respect to mortality and morbidity rates in the region. The study was conducted in a region where a high density of current or past coal mining combined with a lack of advanced sewage treatment could affect concentrations of commonly occurring constituents plus contaminants, including nitrate, trace metals, major ions, indicator bacteria, radon, hydrogen sulfide, and dissolved hydrocarbons.

Because rural residential wells and mine outfalls are considered private sources of water in the region, and are therefore unregulated and unmonitored, water-quality data are sparse. To fill the data gap and assess the groundwater quality in the region, water-quality samples were collected from 60 sites in a 10-county area. The 60 sites sampled included 46 rural residential homeowner wells and 14 mine outfall

${ }^{1}$ U.S. Geological Survey, Virginia and West Virginia Water Science Center, 11 Dunbar Street Charleston, WV 25301.

${ }^{2}$ U.S. Geological Survey, Water Mission Area, Earth Systems Processes Division-Water Cycle Branch, 12201 Sunrise Valley Drive, MS 432, rm 5B210, Reston, VA 20192. discharges used for residential supply. For this study, all samples were collected prior to any filtration or other treatments, typically at the pressure tank, and are indicative of total and dissolved constituents in the untreated water.

Generally, data for the 60 sites indicate that most waters sampled do not exceed thresholds for most U.S. Environmental Protection Agency (EPA) drinking-water standards and U.S. Geological Survey (USGS) drinking-water screening criteria. However, there were several notable exceptions. Turbidity exceeded the 5-Nephelometric Turbidity Unit (NTU) EPA treatment technique (TT) drinking-water standard in 14 of 60 (23 percent) sites sampled and exceeded the 1-NTU TT standard in 51 of 60 ( 85 percent) sites sampled. Turbidity is common in many wells in southern West Virginia and may be attributed to iron oxyhydroxide precipitates, sediment carried into the aquifers from the shallow soil zone due to improperly constructed or cased wells or transported to the aquifer in shallow stress-relief fracture zones or through permeable beddingplane partings. For the sites sampled, 31 of 60 (52 percent) had $\mathrm{pH}$ values at, above, or below the upper and lower range of the EPA Secondary Maximum Contaminant Level (SMCL, 6.5-8.5 standard units). Of those 31 sites, 28 (90 percent) were indicative of acidic corrosive water and 3 (10 percent) were indicative of alkaline water.

The Langelier Saturation Index (LSI), which is a measure of the corrosivity of the water, was computed for all sites sampled for the study. Eighty-two percent of the sites sampled had waters that were classified as corrosive, based on a LSI less than -0.5 . Corrosive water has the potential to leach lead, copper, and other metals from lead, copper, galvanized, or lead-tin soldered connections in water lines. The chloride to sulfate mass ratio also was assessed with the alkalinity to indicate the potential to promote galvanic corrosion (PPGC) of water lines and plumbing fixtures. Only one of the sites (1.7 percent) classified as a corrosive water site, had a PPGC considered high; the remaining sites were classified as having either a moderate (53.3 percent) or low (45 percent) PPGC. Therefore, the type of plumbing systems sampled for this study may be affected by corrosive water, but the potential for leaching trace metals and other constituents from residential plumbing systems containing older galvanized pipes or lead-tin soldered copper pipes is moderate to low. 
The indicator bacteria total coliform and Escherichia coli (E. coli) also were detected in groundwater samples to varying degrees. Total coliforms, which are a broad class of indicator bacteria, are common in groundwater in southern West Virginia and were detected in 39 of the 60 sites ( 65 percent) sampled. The presence of total coliform bacteria is a potential indicator of surface contamination, due to improperly constructed or cased wells, or infiltration of soil or other surface contaminants into the aquifer or well bore. E. coli bacteria, however, are much more indicative of fecal contamination of groundwater from either human or animal sources, and 14 of the 60 (23 percent) sites sampled had detections of $E$. coli. Although only a few strains of $E$. coli are known pathogens, their presence in groundwater may be an indicator of other related pathogens such as viruses and should be regarded as a serious potential issue. Water treatment such as chlorination, ozonation, or ultraviolet light may be appropriate to kill potential pathogenic bacteria or viruses in the source water.

Manganese and iron were prevalent contaminants in the groundwater samples collected for this study, with 30 of 60 (50 percent) sites analyzed for manganese and 25 of 60 (42 percent) sites analyzed for iron exceeding the proposed 50- and 300-micrograms per liter $(\mu \mathrm{g} / \mathrm{L})$ SMCL drinkingwater standards, respectively, for aesthetic criteria such as taste, odor, or staining of plumbing fixtures. Fourteen of the 60 sites sampled (23 percent) had concentrations of manganese that exceeded the $300-\mu \mathrm{g} / \mathrm{L}$ USGS health-based screening level, and 1 site exceeded the 1,600- $\mu \mathrm{g} / \mathrm{L}$ EPA drinking-water equivalent level, which is based on a lifetime exposure level. Sodium is another common constituent in groundwater within the study area. Sodium has an EPA health-based value (HBV) of 20 milligrams per liter $(\mathrm{mg} / \mathrm{L})$ for individuals who are on a sodium-restricted diet for blood pressure or other health reasons. Sodium concentrations exceeded the 20-mg/L EPA HBV in 27 of 60 (45 percent) samples.

Radon, a naturally occurring carcinogenic radioactive gas known to cause lung cancer, was detected at concentrations at or exceeding the proposed 300-picocuries per liter $(\mathrm{pCi} / \mathrm{L})$ EPA Maximum Contaminant Level (MCL) in 12 of the 60 (20 percent) sites sampled. Sites with radon gas concentrations exceeding the $300-\mathrm{pCi} / \mathrm{L}$ proposed MCL have the potential for airborne concentrations of radon to exceed the 4-pCi/L indoor air standard. Inhalation of radon can cause lung cancer, and the 4-pCi/L indoor air standard is based on an inhalation standard. Therefore, homeowners whose wells have radon gas concentrations exceeding $300 \mathrm{pCi} / \mathrm{L}$ may be advised to have their indoor air tested to determine if indoor air concentrations exceed the 4-pCi/L indoor air standard established by the EPA.

Various factors were analyzed statistically and graphically to determine whether they have an influence on groundwater quality within the study area, including topographic setting, well depth, type of mining (surface or underground), type of site (well or mine outfall), and geologic formation. Only geologic formation and the type of site sampled had strong statistical correlations with one or more of the constituents of concern for this study. The overall chemistry of outfalls (mine outfalls) and wells was significantly different, with a much higher dissolved oxygen content in outfalls than in wells. The dissolved oxygen content is the primary component driving the oxidation and reduction of minerals, and the precipitation of minerals that are saturated or super saturated with respect to various cations and anions. Median dissolved oxygen concentrations for the outfalls sampled was $8.75 \mathrm{mg} / \mathrm{L}$, and only $0.4 \mathrm{mg} / \mathrm{L}$ for the wells sampled.

Median concentrations of sulfate and selenium were much higher in waters from the outfalls sampled, with median concentrations of $73.75 \mathrm{mg} / \mathrm{L}$ and $2.35 \mu \mathrm{g} / \mathrm{L}$, respectively, compared to the wells sampled, which had median concentrations of $18.3 \mathrm{mg} / \mathrm{L}$ and less than $(<)$ the $0.05-\mu \mathrm{g} / \mathrm{L}$ method detection limit, respectively. The maximum selenium concentration was for a well, with a concentration of $16.6 \mu \mathrm{g} / \mathrm{L}$. The geochemical processes that control sulfate and selenium concentrations in groundwater are similar and are the result of the oxidation of sulfide minerals such as pyrite and ferroselite. Iron and manganese concentrations were elevated in most of the wells sampled, with median concentrations of 369.5 and $124.5 \mu \mathrm{g} / \mathrm{L}$, respectively, but were rarely detected in the outfalls sampled, with median concentrations of $<4.0$ and $<0.4 \mu \mathrm{g} / \mathrm{L}$, respectively. The difference in iron and manganese between wells and outfalls is indicative of the role of dissolved oxygen on processes controlling groundwater chemistry in the region.

Three principal geologic formations were assessed for the study, and the overall chemistry for the Pocahontas, New River, and Kanawha Formations varied substantially with respect to several constituents. Concentrations of calcium, magnesium, and total dissolved solids were highest for sites sampled in the Pocahontas Formation, with median concentrations of $41.8,18.6$, and $312 \mathrm{mg} / \mathrm{L}$, respectively. For constituents that are commonly associated with mining activity, the highest concentrations were for sites sampled in the New River Formation, with median concentrations of iron and manganese of $2,450 \mu \mathrm{g} / \mathrm{L}$ and $482 \mu \mathrm{g} / \mathrm{L}$, respectively, and a median $\mathrm{pH}$ of 6.35 standard units. Concentrations of barium also were elevated in samples collected from sites in the New River Formation, with a median barium concentration of $184 \mu \mathrm{g} / \mathrm{L}$. The source of the barium is not fully known but may be associated with commingling of shallow groundwater with deeper brines or dissolution of the mineral barite. The highest median sulfate concentrations were from sites sampled in the Pocahontas Formation, with a median concentration of $64.0 \mathrm{mg} / \mathrm{L}$. Of the 12 sites at or exceeding the $300-\mathrm{pCi} / \mathrm{L}$ proposed drinking-water standard for radon, 8 ( 67 percent of MCL exceedances) were for sites deriving water from the Kanawha Formation, 3 ( 25 percent of MCL exceedances) were for sites deriving water from the New River Formation, and only 1 site was for water from the Pocahontas Formation (8 percent of proposed MCL exceedances).

Dissolved hydrocarbons, including methane, ethane, propane, propene, $n$ - and $i$-butane, 1-butene, $n$ - and $i$-pentane, pentane, 2- and 3-ethyl pentane, hexane, and benzene were analyzed in samples collected from 59 of the 60 sites to assess 
the potential occurrence and sources of these trace gases in groundwater within the study area. Results of the analysis indicate that most of the gas is of shallow biogenic origin, possibly associated with coal-bed methane, but a subset of samples has a gas signature and a chloride to bromide ratio indicative of potential mixing with deeper thermogenic gases. Only 2 of the 59 (3.4 percent) sites sampled had concentrations of methane gas, which is a highly combustible and explosive gas, exceeding the 10 milligrams per kilogram level of concern established by the U.S. Office of Surface Mining Reclamation and Enforcement.

Principal components analysis was used to assess the primary geochemical processes occurring in the aquifers sampled. The first principal component had significant positive loadings for bromide, chloride, silica, ammonia, barium, iron, manganese, and arsenic, and significant negative loadings for dissolved oxygen, potassium, nitrate, and uranium, and reflects reduction and oxidation (redox) processes occurring in deeper anoxic groundwater or shallow oxic groundwater. The strong positive loadings for iron, manganese, barium, and arsenic are correlated with reducing conditions often found deeper in the aquifer. More oxic water is correlated with oxidation of nitrogen species to nitrate and environmental mobilization of uranium and sulfate in shallow wells and mine outfalls.

\section{Introduction}

West Virginia's southern coal-field province includes parts of 10 counties in southern West Virginia. The area is part of the Central Appalachian Basin coal region of the Eastern Coal Province where ongoing and historical coal mining activity dates to the mid-1800s. The area is one of the most intensely mined areas within the United States with respect to the extraction of coal, both by surface and underground methods. Prior to about 1970, the Appalachian Basin accounted for more than 70 percent of coal production within the United States, but in recent years has been surpassed in production by mining in the western United States in Montana and Wyoming (Milici and Polyak, 2014).

Recent studies by the Centers for Disease Control and Prevention (CDC) and other entities have shown that the mortality rates for a variety of serious, chronic conditions, such as diabetes, heart disease, and some forms of cancer in Appalachian coal mining regions, are higher than in areas lacking substantial coal mining activity within the Appalachian Region or elsewhere within the United States (Hendryx and Ahern, 2009). Causes of the increased mortality and morbidity are not clear, but factors such as poor diet, high rates of smoking, and other socioeconomic factors may contribute to the higher than average mortality rates in the region. Environmental factors related to the mining of coal, such as the potential degradation of groundwater and surface-water quality, may be additional causes of the increased mortality and morbidity in the region.
A previous study conducted by the U.S. Geological Survey (USGS) as part of the National Water-Quality Assessment (NAWQA) Project indicated that groundwater quality within about 500 feet (ft) of surface-mined sites had elevated sulfate and metals concentrations compared to background levels that were present in wells more than 1,000 ft downgradient of mined sites (McAuley and Kozar, 2006). The study investigated groundwater quality only with respect to proximity to reclaimed surface mines, and assessments of groundwater quality with respect to underground coal mining in the region or in relation to active surface mining were not assessed as part of the study. Therefore, additional data for quantitative assessment of the quality of groundwater used for rural residential water supply in the region was needed.

\section{Purpose and Scope}

This report presents analytical data for groundwater samples collected from 60 sites in West Virginia's southern coalfield province during the summers of 2016 and 2017. The 60 sites sampled included 46 rural residential homeowner wells and 14 mine outfalls. Mine outfall discharges, often referred to as mine springs, are a common and unregulated source of water for residents of southern West Virginia, especially those who live on mountaintops and haul water for their cisterns due to low or minimal water availability from wells in such topographic settings. Mine outfalls commonly emanate from old abandoned mine portals, or where coal seams are eroded or exposed along the contour of hillsides. Because rural residential wells and mine outfalls are considered private sources of water and are therefore unregulated and unmonitored, water-quality data are sparse and insufficient to characterize the groundwater quality of the region. This study focused on rural residential water supplies from wells and mine outfalls in areas with high intensity current or past coal mining activity to provide a baseline dataset of groundwater-quality data for current assessment and future comparison.

This study was conducted by the USGS in cooperation with the West Virginia Department of Health and Human Resources and the West Virginia Department of Environmental Protection, with grant support from the CDC to assess the quality of groundwater in southern West Virginia. The data from this assessment of groundwater quality may be used by the $\mathrm{CDC}$ and other agencies to potentially investigate the role or lack thereof of groundwater quality with respect to mortality and morbidity rates in the region.

The groundwater samples were analyzed for chemical and physical properties, including nutrients, major ions, trace elements and metals, indicator bacteria, radon, methane and other dissolved hydrocarbon gases. The groundwater-quality data and summary statistics are presented to assess current groundwater-quality conditions in the region, which has been heavily mined for coal both in the past and currently and are compared to drinking-water standards to identify potential 
water-quality problems. In addition, the data were analyzed statistically using multivariate statistical methods to assess potential correlations with topographic setting, site type, well depth, and other factors. Finally, the data were used to calculate mineral saturation indices (SIs) to better understand geochemical controls on groundwater quality, including reduction/ oxidation (redox) and other geochemical processes that control groundwater quality.

\section{Description of Study Area}

The study area for this investigation is West Virginia's southern coal-field province, which is in the southern part of the State within the Central Appalachian Basin coal region. The study area includes parts of 10 counties, covering approximately 4,238 square miles $\left(\mathrm{mi}^{2}\right)$, including parts of McDowell, Mercer, Wyoming, Raleigh, Fayette, Mingo, Logan, Boone, Lincoln, and Kanawha Counties (fig. 1) and is completely within the Appalachian Plateaus Physiographic Province (Fenneman, 1938; Fenneman and Johnson, 1946; U.S. Geological Survey, 1970).

The area consists of rugged, deeply incised hilly terrain with uplifted plateaus capped by resistant layers of relatively flat-lying sandstone and shale. Geologic nomenclature used in this report is that of the West Virginia Geological and Economic Survey (WVGES). The study area is underlain by gently dipping, relatively flat lying, slightly folded sandstone, siltstone, shale, limestone, and coal of Mississippian, Pennsylvanian, and Permian ages. Approximately 65 coal seams of major substantial extent have been identified by the WVGES (West Virginia Geological and Economic Survey, 2019) within the study area (accessed February 5, 2018, at http://www. wvgs.wvnet.edu/www/coal/cbmp/coalims.html). The study area is completely within the Central Appalachian Basin coal region and makes up West Virginia's southern low-sulfur coal fields. Cecil and others (1985) indicated that the low-sulfur coals are the group of coals with median sulfur content of less than 1.0 percent in the Central Appalachian coal region. Tully (1996) characterized the sulfur content as less than 1.5 percent.

The differences in coal (and adjacent rock) sulfur content between West Virginia's southern and northern coal fields are due to depositional environments. The older rocks in the southern coal-field province were deposited in an area that received more paleo-rainfall and paleo-recharge and thus the sulfur content was diluted compared to the younger rocks in the northern coal field, which formed in a drier paleoclimate with higher ash, nutrient, and dissolved solids content that combined to result in higher sulfur content (Cecil and others, 1985). The younger rocks were deposited in marine environments that had higher contents of sulfur and calcium carbonate. In contrast, the older rocks formed in areas that were marginally brackish, resulting in a lower content of sulfur and calcium carbonate. However, within most of the rocks of both ages, there are formations that represent marine, brackish, and marginally brackish paleoenvironments and each of these have both high and low sulfur content.
Cecil and others (1985) indicated that the dividing line between the high-sulfur coal region and the low-sulfur coal region lies generally along the contact between the younger Pennsylvanian-aged rocks of the Allegheny and Conemaugh Formations and the older Pennsylvanian-aged rocks of the Pottsville Group (Kanawha, New River, and Pocahontas Formations of West Virginia) in southern West Virginia (fig. 2).

Average annual precipitation for the study area for the period from 1981-2010 ranges from a minimum of 41.19 to a maximum of 47.51 inches per year (in/yr) with mean and median precipitation for the region of approximately 45.33 and $45.78 \mathrm{in} / \mathrm{yr}$, respectively. Precipitation is distributed unevenly with respect to topography and climatological regions (National Oceanic and Atmospheric Administration, 2018) (accessed September 20, 2019, at https://www.ncdc.noaa.gov/ cdo-web/datasets/NORMAL_ANN/locations/FIPS:54/detail). Areas at higher elevation typically receive higher average amounts of precipitation than areas at lower elevation.

Public supplies are the principal source of water used for residential supply in the region, accounting for 90 percent (72.1 million gallons of water per day [Mgal/d]) of all freshwater withdrawals for residential use. An estimated 91,000 people, however, rely on private wells or unregulated water sources such as mine outfalls for their daily water needs, withdrawing approximately $7.28 \mathrm{Mgal} / \mathrm{d}$ (U.S. Geological Survey, 2018a) (accessed February 5, 2018, at https://waterdata.usgs. gov/wv/nwis/water_use/). In the more rural counties (excluding Kanawha County), self-supplied rural, residential, groundwater withdrawals increase to 16 percent of all freshwater withdrawals for residential supply. The majority of water used for public supply in the region (88 percent) is derived from surface-water sources, primarily stream withdrawals. For rural residential homeowners, however, almost 100 percent of their withdrawals are derived from groundwater (wells and [or] springs, including mine outfalls).

\section{Hydrogeologic Setting and Groundwater Flow}

The study area is within the Appalachian Plateaus Physiographic Province (Fenneman, 1938), and is characterized by highly dissected nearly flat-lying sedimentary rocks consisting primarily of sandstone, siltstone, mudstone, limestone, and coal. The generalized hydrogeologic framework of the study area is based on regional topography, stratigraphy, and structure, with upland plateaus formed by resistant clastic rocks and valleys developed in zones of structural weakness. Structurally, the rocks in the Appalachian Plateaus study area are nearly flat to gently folded and commonly fractured. Pennsylvanian-age clastic rocks form the predominant outcropping units in the uplands and valley walls of southern and central West Virginia (Cardwell and others, 1968). Pennsylvanian and Permian stratigraphic units consist of sandstone, conglomerate, siltstone, shale, and coal, with local beds of limestone and dolomite. These bedrock units commonly are overlain by a relatively thin layer of regolith or alluvium (Berg and others, 1980). 


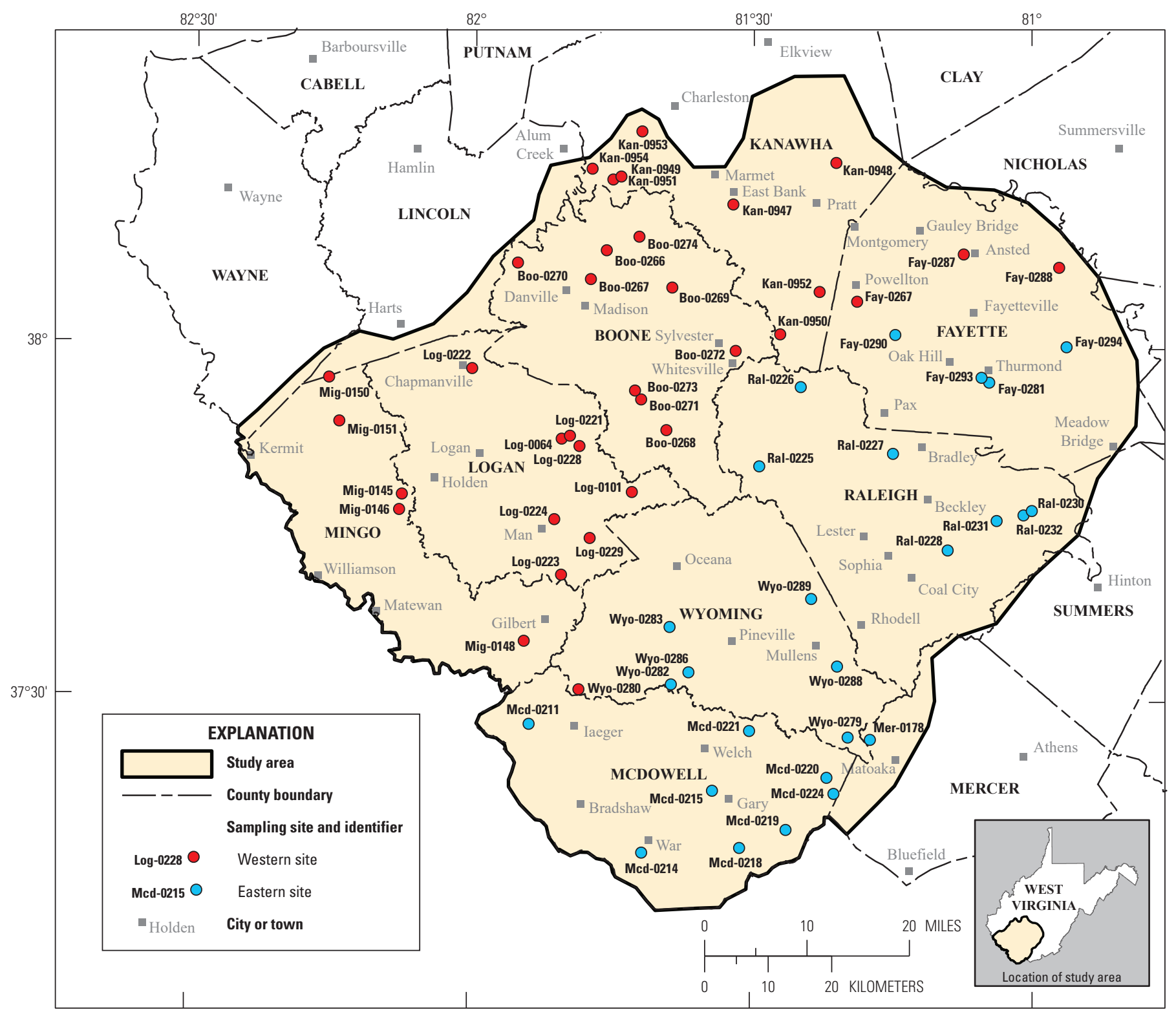

Figure 1. Location of study area and distribution of sites sampled.

Groundwater-flow paths are relatively short and limited to two principal types of aquifer systems: (1) unconsolidated alluvial aquifers made up of sand, silt, clay, and gravel; and (2) fractured-bedrock aquifers including siliciclastic and carbonate sedimentary rocks and associated coal (Puente, 1985). Because they tend to be shallow and thin, the alluvial aquifers present within the study area typically are not used as water supplies but can combine with soil and regolith to provide shallow storage for recent recharge. Fractured-bedrock aquifers are the primary aquifers in the study area. Locally, regolith, where alluvium is not present, is commonly thin with low permeability, providing little groundwater storage. Groundwater storage and flow in bedrock occurs through joints, fractures, and bedding-plane separations (Kozar and Mathes, 2001, p. 11). In the study area, secondary permeability due to jointing and stress-relief fracturing accounts for most of the porosity and permeability in the bedrock, because the original intergranular porosity commonly has been filled by calcium carbonate or silica cementation (Wyrick and Borchers, 1981).

Recharge to fractured-bedrock aquifers in the region occurs primarily as rainfall; snowmelt is only an important source of recharge in areas at elevations above 3,000 ft. Once precipitation falls on the surface, the part that does not run off to streams percolates into and through shallow soils and regolith and eventually recharges fractured-bedrock or alluvial aquifers. A decrease in hydraulic conductivity with depth has 


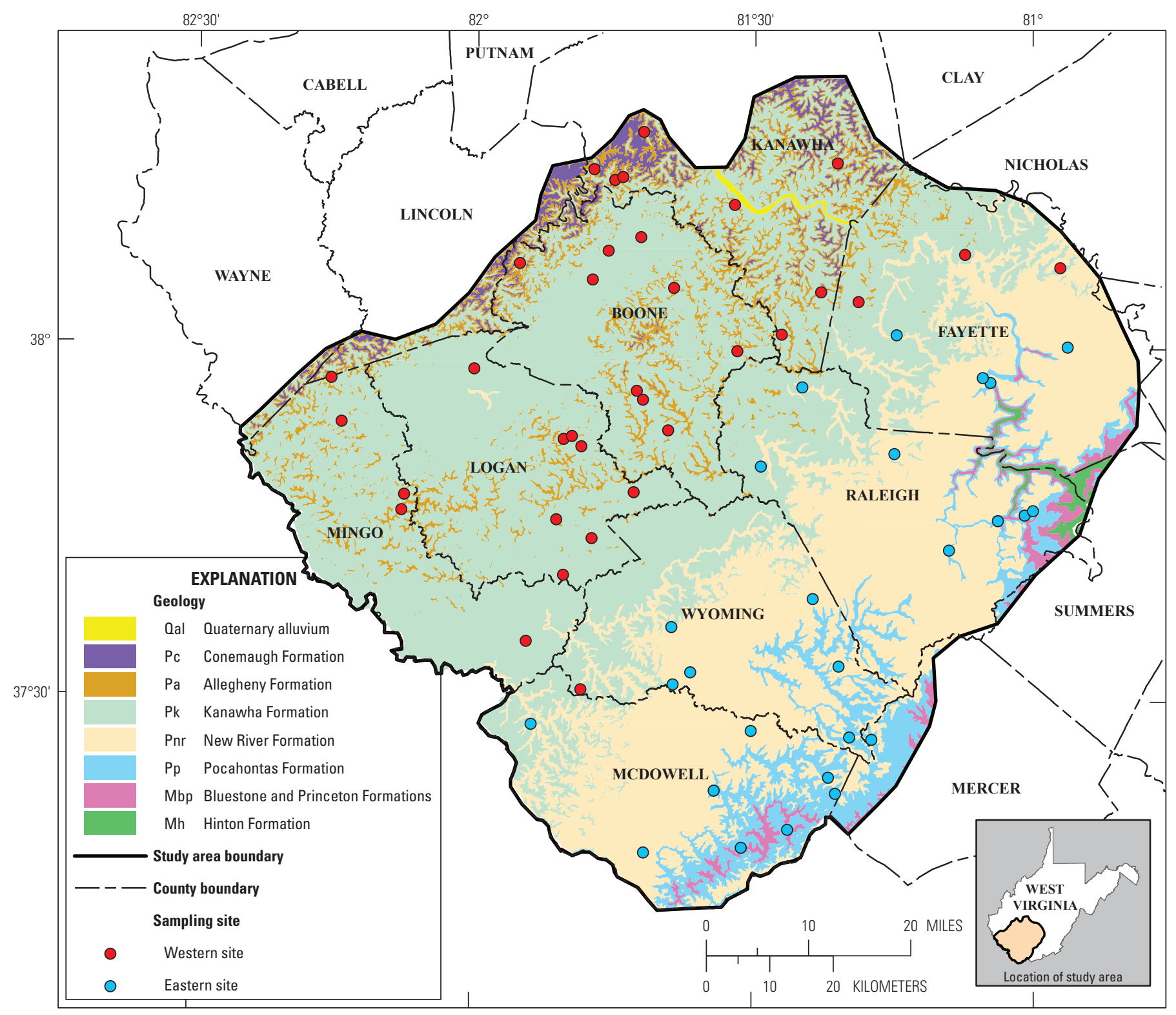

Figure 2. Geology of the West Virginia southern coal-field province and location of groundwater-quality sampling sites.

been documented by several researchers. For a mine site in West Virginia, the average hydraulic conductivity of an aquifer decreased from 2.8 feet per day ( $\mathrm{ft} / \mathrm{d}$ ) at a depth of $150 \mathrm{ft}$ to $0.0003 \mathrm{ft} / \mathrm{d}$ at depths greater than $330 \mathrm{ft}$ (Bruhn, 1985). For a site in Greene County, Pennsylvania, which is in a similar hydrogeologic setting with similar rock composition, hydraulic conductivity decreased by an order of magnitude per $100 \mathrm{ft}$ of depth to a depth of approximately $500 \mathrm{ft}$ (Stoner, 1982). According to Callaghan and others (1998), the vast majority of groundwater circulation occurs at moderate depths of less than $300 \mathrm{ft}$.

In the Appalachian Plateaus, local fractured-bedrock aquifers of less than approximately $5.0 \mathrm{mi}^{2}$ in area are defined by topographic valleys and boundary ridges. Each small valley may contain a locally distinct aquifer from which groundwater discharges to a nearby stream or to deeper subregional or regional aquifers (fig. $3 A$ ). The ridges surrounding the valley define the lateral boundaries of the local aquifer and its principal recharge area. Subregional aquifers (generally from 100 to $500 \mathrm{ft}$ below land surface) occur at intermediate depths between the shallow local aquifer (less than $100 \mathrm{ft}$ below land surface) and deeper regional aquifers. Subregional aquifers are larger than local aquifers and may include several smaller local aquifers. Discharge of groundwater from subregional aquifers is primarily to tributary streams with drainage areas typically much larger than $5.0 \mathrm{mi}^{2}$. A 

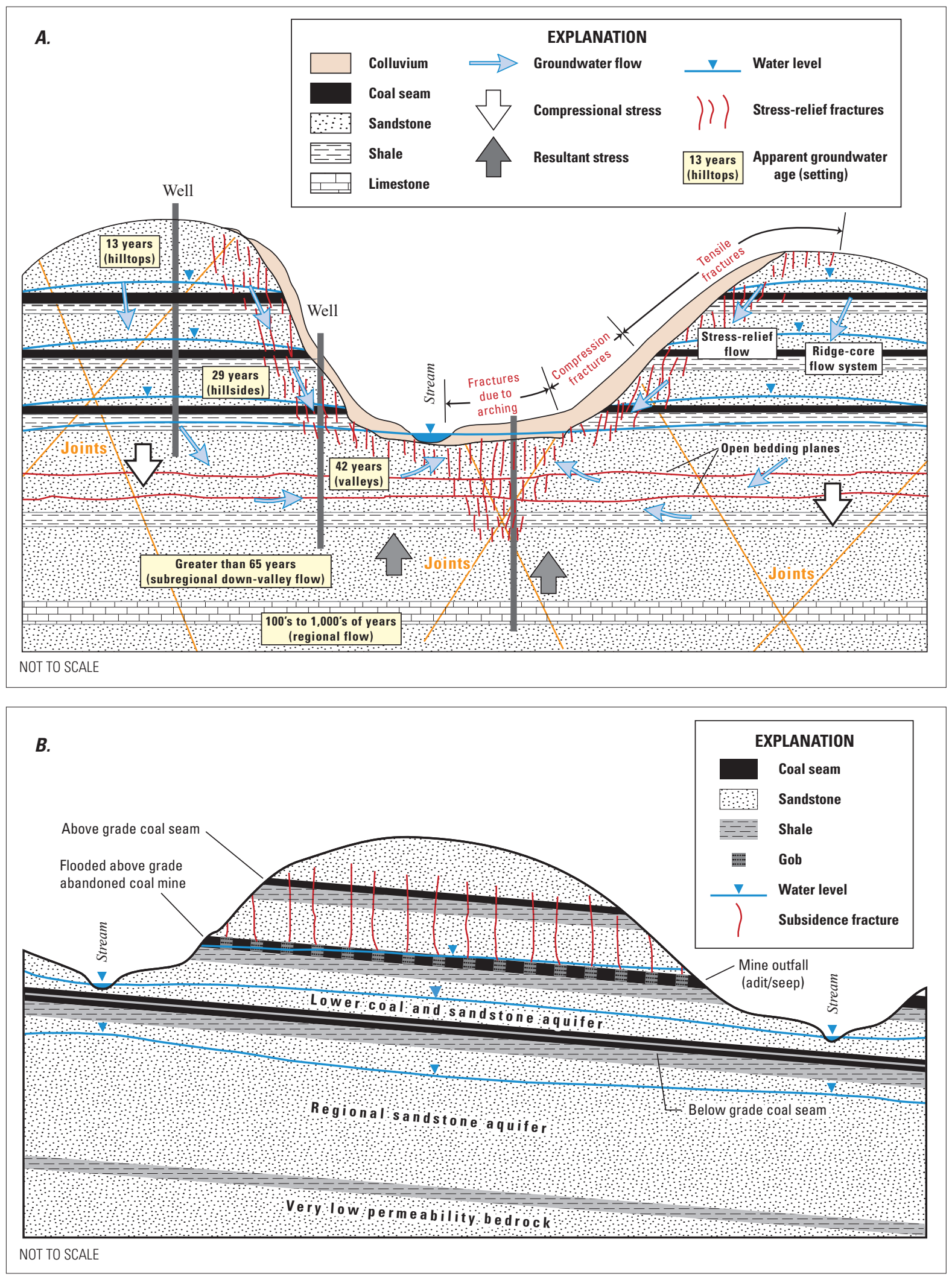

Figure 3. Conceptual models of groundwater flow, $A$, in an unmined Appalachian Plateaus fractured-bedrock aquifer, including apparent age of groundwater and, $B$, in a fractured-bedrock aquifer modified by creation of anthropogenic secondary-permeability features from mine entries within a room and pillar type underground coal mine. 
small component of recharge to these aquifers is from deeper regional aquifers. These intermediate aquifers can extend beneath local topographic divides and discharge to regional aquifers. Depth to saline water (brines) has been used to infer the depth of regional aquifers (Callaghan and others, 1998). In West Virginia, the depth to brackish water ranges from more than 2,000 ft near the southern part of the study area in West Virginia to a minimum of less than $50 \mathrm{ft}$ in areas bordering the Ohio River (Foster, 1980). Regional aquifers may contain saline or brackish water and typically discharge to large rivers.

Within the local aquifers, groundwater typically flows from hilltops to valleys, perpendicular to local tributary streams, through an intricate network of stress-relief fractures and interconnected bedding-plane separations, commonly in a stair-step pattern (fig. 3A) (Wyrick and Borchers, 1981; Harlow and LeCain, 1993). Vertical hydraulic conductivity can be negligible, resulting in horizontal groundwater flow (especially within coal seams) that discharges as springs or seeps in hillsides and valleys (Harlow and LeCain, 1993). A small proportion of the groundwater flows deeper within the central core of the mountain or ridge, especially within coal seams and along bedding-plane separations, and likely reaches the valley to discharge locally to surface water, or it may recharge subregional and regional aquifers. Groundwater flow in valleys primarily occurs in bedding-plane separations beneath valley floors and in vertical and horizontal stressrelief fractures along valley walls (Wyrick and Borchers, 1981). Enhanced permeability of bedrock in valleys may result in groundwater flow parallel to and beneath local tributary streams before ultimately discharging to surface-water bodies.

The yield of wells completed within the study area has long been postulated to be a function of topographic setting and dominance of stress-relief fractures in valleys and hillsides, and the absence of such fractures on hilltop settings (Wyrick and Borchers, 1981). These processes were documented in a study conducted at Twin Falls State Park in Wyoming County, West Virginia (Wyrick and Borchers, 1981), and are often referenced in hydrogeologic literature for the Appalachian region. Well yield data for 777 wells in the 13 counties in southern West Virginia (Kozar and others, 2012) coincident with the geographic area for this study fully support the concepts of Wyrick and Borchers (1981), which were based on earlier work by Ferguson (1967). A boxplot of the well-yield data for the 777 wells retrieved from the USGS National Water Information System (NWIS) database (fig. 4) and topographic assessment from digital elevation models shows distinct differences with respect to topographic setting, with wells in valleys having significantly higher yields than wells on hilltops; wells in hillside settings showing intermediate well yields caused by the gradation from maximum stress-relief fracturing in valleys to little or no stress-relief fracturing on hilltops.

The age of water in the subregional aquifer systems of the study area is not well documented. Based on ages of water in deeper wells sampled in West Virginia (Kozar, 1998), subregional groundwater is at least 57 years old, but may be

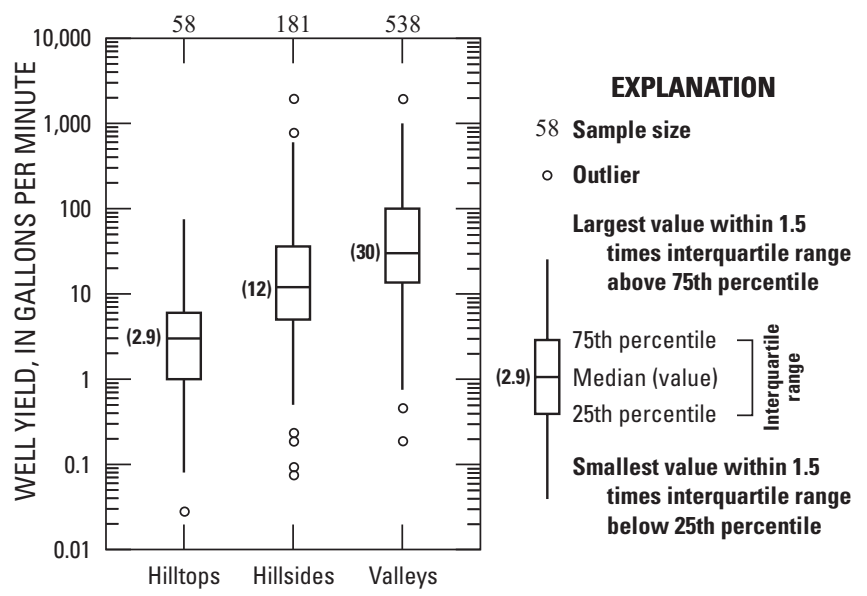

Figure 4. Distribution of well yields with respect to topographic setting, based on analyses of U.S. Geological Survey National Water Information System data for 777 wells in 13 counties in the West Virginia southern coal-field province.

much older, perhaps even centuries old. Deep saline brines in regional aquifers may be thousands of years old.

Surface and underground coal mines can substantially change surface-water and groundwater-flow patterns by altering recharge areas, recharge rates, and the porosity and permeability of local aquifers (see figs. $3 A$ and $3 B$ ). Although underground mines may not extensively disturb the overlying land surface, and surface coal mines can be reclaimed to mimic the original contours of the land surface before mining (contoursurface mines), the post-mining hydrology may differ from the surrounding undisturbed areas. Post-mining groundwater flow in and through reclaimed contour-surface mines depends on many factors, including the dip of bedrock at a mine, the composition and permeability of material within spoil, the age of spoil, and engineering controls such as ditches, terraces, sediment retention basins, ponds, and flumes or chutes. Each reclaimed surface mine has its own local ground- and surfacewater-flow system. However, there are aspects common to most reclaimed contour-surface mines (Hawkins, 1998a, 1998b). Typically, groundwater will pool at the base of the surface-mine bench or at the lowest elevation of an underground mine (fig. $3 B$ ). Recharge to the groundwater at a mine can originate as surface drainage through spoil and unmined areas upgradient of the backfilled contour bench (Hawkins, 1998a), including surface drainage that flows into the mine area. If the coal seam dips away from the highwall, there may be little water stored within the spoil because groundwater can freely flow downdip through spoil in the absence of a low permeability coal barrier. Where a coal seam dips towards a highwall, however, groundwater commonly will accumulate and flow laterally along the base of the highwall until it emerges at the surface as springs or seeps. Water emerging in springs and seeps may be conveyed away from a reclaimed 
contour-surface mine by ditches or drains to a nearby tributary stream and may be lost as a potential source of recharge. Mine spoil typically exhibits dual porosity, especially when more than one type of bedrock makes up the spoil (for example, sandstone, which usually consists of coarse-grained deposits such as sand, gravel, and boulders, and shale, which typically consists of fine-grained deposits within the spoil). Even where only one type of bedrock (for example, sandstone) is present within the spoil, differential settling of coarser-grained deposits (boulders and cobbles) is typical at the base of a cast spoil pile with finer-grained deposits (sand, dust, and gravel) near the surface during the backfilling process. Groundwater flow within the spoil is therefore highly variable because of interspersed fine- and coarse-grained deposits within the backfill (McAuley and Kozar, 2006). Stream loss to below drainage underground coal mines is common where streams cross above underground coal mines, especially where the depth to the underground mine is minimal (Cravotta and others, 2017).

A recent study of above drainage underground coal mines completed within the study area (Kozar and others, 2012) quantified interbasin transfer of groundwater from several adjacent surface watersheds, which resulted in abnormally high base-flow discharge in the surface drainage basin receiving the interbasin transfer. Interbasin transfer occurs where coal seams with a consistent structural dip cross beneath surface-water drainage divides. In unmined areas, the surfacewater divides control groundwater discharge, but where extensive underground coal mines are interconnected over a broad area and encompass one or more surface-water drainage basins, groundwater discharge is controlled by the dip of the coal seam and substantial interbasin transfer of groundwater is common.

\section{Land Use}

Land use in the study area is predominantly forested, with approximately $3,852 \mathrm{mi}^{2}$ (90.9 percent), and approximately $122 \mathrm{mi}^{2}$ (2.9 percent) of the area is residential or urban areas. The rural region has one dominant industry, which is coal mining. Approximately 2,369 $\mathrm{mi}^{2}$ (56 percent) of the study area has been mined by underground methods and an additional $598 \mathrm{mi}^{2}$ (14 percent) has been mined by surface methods. The percentage of mined area is somewhat misleading, as the percentage is likely much higher due to multiple seams mined in stacked sequences of bedrock. Regardless, coal mining is the dominant industrial land use in the region.

\section{Previous Investigations}

Previous investigations of groundwater quality within the study area are sparse; most prior work focused on hydrogeology. A study was conducted to assess hydrologic characteristics of abandoned coal mines used as sources of public water supply in McDowell County, West Virginia (Ferrell, 1992), and theorized that recharge to the abandoned coal mines from which the City of Welch, West Virginia, derives water for the Welch water system, is likely derived at least partially from induced infiltration from the adjacent Tug River. Since many areas of the Tug River upstream of the City of Welch lack community sewage systems, and the Tug River receives discharge of untreated residential sewage effluent, bacterial contamination of the abandoned mine aquifer is a concern. Similarities in water levels for the abandoned mine aquifer in which the wells of the Welch water system are completed and other adjacent abandoned mines indicates the potential for substantial interaction between various interconnected abandoned mine complexes, resulting in a large but heterogeneous recharge area. However, the study did not assess the microbial quality of the water derived from the abandoned Exeter mine, the source of water for the Welch water system.

During the late 1970s through the early 1980s, the USGS studied the hydrology, including water quality, in areas of active coal mining within the Appalachian Region (Ehlke and others, 1982a, 1982b; Kiesler and others, 1983). These studies provided a good investigation of surface-water quality within the study area, but gave only a cursory summary of groundwater-quality issues within the study area, focusing primarily on common ions and acid mine drainage constituents such as iron, manganese, $\mathrm{pH}$, and sulfate. In fact, the Area 9 report did not discuss groundwater quality at all (Ehlke and others, 1982b).

An intensive study of the hydrogeology and groundwaterflow processes for an abandoned coal-mine aquifer in the Elkhorn area of McDowell County, West Virginia, provided a detailed description of interbasin transfer of groundwater caused by interconnected abandoned coal-mine workings that convey water beneath topographic surface-water drainage divides (Kozar and others, 2012). Interbasin transfer of groundwater beneath surface-water drainage divides can cover extensive areas, making delineation of groundwater capture areas for abandoned mine aquifers difficult. Assessment of source-water protection areas for wells or springs derived from abandoned mine aquifers must account for potential interaction between adjacent mines and assess the potential for interbasin transfer of groundwater. However, the study was designed to investigate groundwater-flow processes rather than groundwater-quality issues, and therefore included groundwater-quality data for only two wells.

A study to assess the water resources of the Tug Fork River Basin in West Virginia, Kentucky, and Virginia, and the Twelvepole Creek Basin in West Virginia, focused on surface water as was the case with many of the areal investigations conducted in the study area. The study examined well-yield and water-quality data available for 350 wells, some of which were in Kentucky (Bader and others, 1989). The study found that well yields exhibited topographic trends, with the highest median well yields of 32 gallons per minute ( $\mathrm{gal} / \mathrm{min}$ ) occurring in valley settings and the lowest median well yields of $0.58 \mathrm{gal} / \mathrm{min}$ occurring on hilltops, with hillside wells having an intermediate median well yield of $6.0 \mathrm{gal} / \mathrm{min}$. The primary finding of the study was that constituents such as iron, 
manganese, sulfate, and dissolved solids were much higher in wells near mining than in wells located farther away and considered to be unaffected by mining activity. Median concentrations of total dissolved solids (TDS), iron, manganese, and sulfate for wells considered to be affected by mining were 312 milligrams per liter ( $\mathrm{mg} / \mathrm{L}), 4,200$ micrograms per liter $(\mu \mathrm{g} / \mathrm{L}), 420 \mu \mathrm{g} / \mathrm{L}$, and $120 \mathrm{mg} / \mathrm{L}$, respectively, whereas median concentrations for the same constituents in wells unaffected by coal mining were $187 \mathrm{mg} / \mathrm{L}, 565 \mu \mathrm{g} / \mathrm{L}, 130 \mu \mathrm{g} / \mathrm{L}$, and $14 \mathrm{mg} / \mathrm{L}$, respectively. There also was an obvious trend with respect to carbonate hardness, with wells sampled near mining activity having a much higher median ratio of non-carbonate to carbonate hardness $(0.47)$ than wells in areas unaffected by coal mining $(<0.1)$.

A study to assess the effects of coal mining on the hydrologic environment of selected stream basins in southern West Virginia was completed in 1991 (Borchers and others, 1991). Although the study was primarily an assessment of stream-water quality, the report also discussed stress-relief fracturing and groundwater-flow processes related to coal mining and included a limited amount of data and discussion concerning groundwater quality in mined areas. The study found that wells overlying or within 0.5 mile (mi) of mining activity had substantially different groundwater quality than wells $0.5 \mathrm{mi}$ or more downgradient of mining activity. Specific conductance, sulfate, calcium, sodium, and bicarbonate were found to be statistically significantly different between wells near mine areas as compared to wells more distant from mined areas based on a dataset of 158 wells sampled for the project. The project was a follow up to a previous study to document the role of stress-relief fractures in controlling groundwater flow in the Appalachians (Wyrick and Borchers, 1981), which concluded that stress-relief fractures that form as a result of isostatic rebound due to stress relief from erosion of overlying strata in Appalachian Valleys cause vertical stress-relief fractures to form in valley walls and cause upward arching and separation of bedding in valley bottoms. The conclusions from this study have become widely accepted as the primary process governing groundwater flow in the Appalachian Plateaus Physiographic Province.

One of the more comprehensive studies of groundwater quality related to surface-coal mining was conducted by the USGS National Water-Quality Assessment Project (McAuley and Kozar, 2006), and was based on data for 58 wells sampled downgradient of reclaimed surface mines, and an additional 25 wells in unmined areas in northern West Virginia and Pennsylvania. The study indicated that groundwater near mines in the high-sulfur coal region, north of the study area, had significantly greater median concentrations of sulfate, hardness, calcium, and specific conductance compared to those in the unmined high-sulfur coal region, and to both mined and unmined areas in the southern West Virginia low-sulfur coal region. Groundwater in mined areas had median values of mine-drainage constituents (sulfate, iron, manganese, aluminum, hardness, calcium, magnesium, turbidity, and specific conductance) that were significantly greater than the medians for wells in unmined areas. Mine-drainage constituents generally exceeded unmined-area background concentrations within about $500 \mathrm{ft}$ of mined sites but were at or below background levels in wells more than $1,000 \mathrm{ft}$ downgradient of mined sites.

A simulation of rainfall runoff-response was conducted as part of a comparison for mined and unmined watersheds in West Virginia (Puente and Atkins, 1988). The study used the Precipitation Runoff Modeling System (PRMS) to simulate and compare rainfall-runoff response for selected basins in West Virginia. The study found that the base-flow contribution significantly increased, and surface runoff significantly decreased, for mined watersheds compared to unmined watersheds.

A statewide assessment of groundwater quality in West Virginia based on data collected from 1993 through 2008 for 326 sites found that iron and manganese commonly exceeded U.S. Environmental Protection Agency (EPA) Secondary Maximum Contaminant Level (SMCL) drinking-water standards in 57 and 62 percent, respectively, of the sites sampled (Chambers and others, 2012). Pennsylvanian- and Permianage bedrock aquifers contain the minable coal seams within the State of West Virginia. The lowest median sulfate levels for the sites sampled were from Pennsylvanian-age bedrock aquifers. Coal seams in West Virginia's southern coal-field province of lower Pennsylvanian age typically have much lower pyrite and total sulfur content than younger coal seams of upper Pennsylvanian and Permian age. The highest median iron concentrations were found in Pennsylvanian-age bedrock aquifers and exceeded the $300 \mathrm{mg} / \mathrm{L} \mathrm{SMCL}$, but the data were not separated with respect to differences between West Virginia's northern and southern coal-field provinces. Permian-age bedrock aquifers, which also contain minable coal seams, had median iron concentrations well below the $300 \mathrm{mg} / \mathrm{L} \mathrm{SMCL}$ drinking-water standard.

A report assessing hydrogeologic terrains, well-construction characteristics, groundwater hydraulics, and water-quality and microbial data for the determination of surface-water influenced groundwater supplies in West Virginia was based primarily on the 326-site statewide water-quality assessment and additional data gathered for the study (Kozar and Paybins, 2016). The study found that abandoned coal-mine aquifers, which are typically used as a source of groundwater in southern West Virginia, are moderately susceptible to contamination. The vast network of voids and extensive interconnected underground mine workings provide vast storage for groundwater in abandoned mine aquifers, and fracturing of overburden strata, which is common in areas of past or current mining and can allow rapid infiltration of contaminants to the aquifer. Where streams cross over below-drainage underground coal mines, there is an increased potential for contamination of coal-mine aquifers by untreated sewage discharged to receiving streams. Above-drainage underground coal mines (mines that are present at an elevation above local tributary drainage) are less susceptible to microbial contamination than belowdrainage underground coal mines, due to the lack of major 
overlying tributary streams that can contain elevated loads of microbial contaminants. Public groundwater supplies in abandoned coal mines need to be evaluated on a case-by-case basis to assess the potential for recharge of contaminated surface water to enter below-drainage underground coal-mine aquifers and to assess the potential hydraulic connectivity to nearby surface-water bodies, such as lakes, ponds, rivers, or streams.

\section{Methods of Data Collection and Analysis}

The factors considered in designing the sampling protocol and selecting sampling sites for this study are discussed in the following sections of the report, along with the methods utilized for sample collection, analysis of water chemistry, determinations of field measured parameters of $\mathrm{pH}$, specific conductance, dissolved oxygen, water temperature, hydrogen sulfide and the indicator bacteria Escherichia coli (E. coli) and total coliform. Revised methods for sampling and analysis of dissolved hydrocarbons and the design of the qualityassurance and quality-control protocols are discussed, as are the methods used for statistical and graphical analysis, and geochemical modeling of the data collected for the study.

\section{Selection of Sampling Sites}

Site selection was primarily based on two criteria. First, sites were selected from areas of active or legacy coal mining in West Virginia's southern low-sulfur coal fields. The second criteria for site selection was based on the geology and type of mining within the study area. There is a definite distinction between the western and eastern parts of the study area that is based on two factors - geology and type of mining. The western part of the study area has a larger proportion of surface mines ( 81.5 percent) than the eastern part of the study area (18.5 percent), whereas the eastern part of the study has a slightly higher proportion of underground coal mines (fig. 5). Geology was an additional factor in site selection as the western part of the study area is dominated by coal mines developed in the Pennsylvanian-age Kanawha and Allegheny Formations, whereas the eastern part of the study area is dominated by coal mines developed primarily in the Pocahontas and New River Formations (fig. 2). As the type of mining and mineralogic composition of the bedrock and coal seams differ between the eastern and western parts of the study area, there is a difference in groundwater quality in bedrock and coal-mine aquifers between the two distinct hydrogeologic settings. Thirty-four sites were included in the dataset for the western region, which is dominated by a larger proportion of surface mining in the Kanawha and Allegheny Formations, and 26 sites were included in the dataset for the eastern region, which is dominated by a larger proportion of underground coal mining.

\section{Sample Collection}

Groundwater samples were collected over the course of two summers from July 11 to September 7, 2016, from the eastern part of the study area, and from June 12 to July 19, 2017, from the western part of the study area. Groundwater samples were collected (U.S. Geological Survey, 2006) and processed (Wilde and others, 2004) according to USGS standard protocols for 46 wells and 14 mine outfalls.

Prior to sampling, wells were purged to remove standing water from the well and ensure that representative water samples were collected. Wells were purged for a sufficient period to allow $\mathrm{pH}$, dissolved oxygen, specific conductance, and water temperature to stabilize, and then water samples were collected and processed to attain stable water chemistry and avoid the effects from the distribution system. As the wells sampled were primarily domestic rural residential wells (one public supply well was sampled) with submersible pumps, and were purged daily as part of routine use, prolonged purging of the well was not required to attain stable water chemistry. Methods applicable for low-yield wells were utilized at a few wells to avoid pulling the water level down to the pump intake, which can cause turbidity issues, aerate the sample water, and potentially damage the well pump. Periodic waterlevel measurements were made and served as the criteria for length of the well purge in conjunction with close monitoring of dissolved oxygen, $\mathrm{pH}$, water temperature, and specific conductance using a multi-parameter water-quality meter, which was calibrated daily.

Teflon sample tubing was connected as close to the wellhead as possible, usually at the pressure tank prior to any sort of treatment, such as a water softener or chlorinator, and pumps were kept running as much as possible to prevent sample contamination from the plumbing or backflow from holding tanks. The sample line was then fed to a manifold with sampling ports and a port for connection of a multi-parameter water-quality sonde. Existing plumbing and well-casing materials included, but were not limited to, steel, galvanized steel, polyvinyl chloride (PVC), and other plastics. The purging procedure minimized potential contamination from the well casing and plumbing. Samples were collected after field properties stabilized, according to standard USGS protocols for the collection of water-quality data (U.S. Geological Survey, 2006).

Samples for bacterial analysis were collected and processed according to standard USGS methods (Myers and others, 2014) and processed using the Colilert system (IDEXX, 2019) (accessed May 15, 2018, at https://www.idexx.com/en/ water/water-products-services/colilert/) according to established methods (American Public Health Association, American Water Works Association, and Water Environment Foundation, 2017), a defined substrate liquid-broth medium method for determination of total coliform bacteria and E. coli. Water samples were collected by cleansing the spigot on the pressure tank or water valve on the discharge line from the pump with isopropyl alcohol, and then the spigot was allowed to 


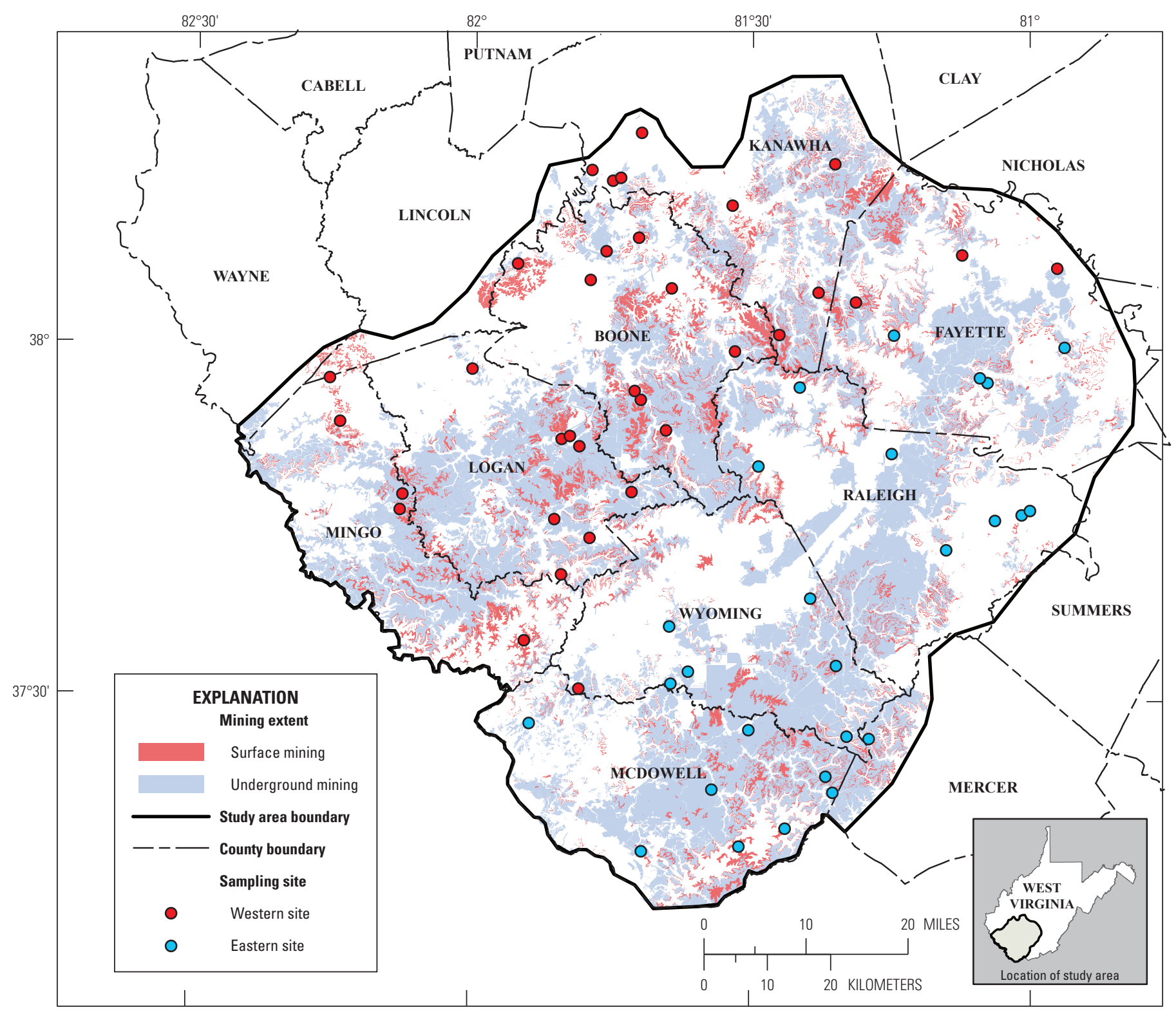

Figure 5. Distribution of sites sampled with respect to mining extent and type.

thoroughly dry before filling a pre-sterilized 100-milliliter $(\mathrm{mL})$ sample bottle. Bacteria samples were collected on site as well and processed within 2 hours of collection and incubated overnight according to USGS standard protocols.

Mine outfalls were sampled by placing a Teflon sampling line in the fracture or void where water was flowing from the mine, and in most cases, allowed to flow through the sampling lines by gravity. For outfalls that had insufficient head to sample by gravity, a peristaltic pump was used to pump water from the mine outfall through the sample lines and attached sampling apparatus. Field properties were measured in the flow-through apparatus in a manner identical to that used for well sampling that was previously described. To prevent environmental contamination, samples typically were collected and processed inside a mobile field laboratory or a portable chamber assembled near the well or the outfall. Sample collection and processing were identical to that for routine samples and field parameters except for bacteria, which were collected by filling the sterile sample bottle directly from the fracture origins of the mine outfall.

All samples were analyzed for field properties, turbidity, alkalinity, major ions, metals, trace elements, and total coliform and E. coli (table 1). Fifty-seven sites were sampled for radon, a carcinogenic radioactive gas. Fifty-nine of the 60 sites also were sampled and analyzed for dissolved hydrocarbons. Samples were processed according to standard USGS protocols (Wilde and others, 2004). Measurements of water temperature, specific conductance, dissolved oxygen 
Table 1. Constituents and reporting limits for major ions, metals, trace elements, nutrients, radon-222, fecal indicator bacteria, and dissolved hydrocarbons analyzed in groundwater samples collected from sites in the West Virginia southern coal-field province.

$[\mu \mathrm{g} / \mathrm{L}$, micrograms per liter; $\mathrm{mg} / \mathrm{L}$, milligrams per liter; $\mathrm{pCi} / \mathrm{L}$, picocuries per liter; col/100 mL, colonies per 100 milliliters of sample; $\mu \mathrm{S} / \mathrm{cm}$, microsiemens per centimeter at 25 degrees Celsius; ng/kg, nanograms per kilogram; *, Sulfide is reported as total sulfide but the method primarily detects hydrogen sulfide gas]

\begin{tabular}{|c|c|c|c|c|c|}
\hline Analyte & $\begin{array}{l}\text { Method } \\
\text { reporting } \\
\text { limit }\end{array}$ & Analyte & $\begin{array}{c}\text { Method } \\
\text { reporting } \\
\text { limit }\end{array}$ & Analyte & $\begin{array}{l}\text { Method } \\
\text { reporting } \\
\text { limit }\end{array}$ \\
\hline Aluminum & $3 \mu \mathrm{g} / \mathrm{L}$ & Nitrogen, nitrite & $0.01 \mathrm{mg} / \mathrm{L}$ & $\mathrm{pH}$ & $\begin{array}{l}0.1 \text { standard } \\
\text { unit }\end{array}$ \\
\hline Antimony & $0.03 \mu \mathrm{g} / \mathrm{L}$ & $\begin{array}{l}\text { Nitrogen, nitrite plus } \\
\text { nitrate }\end{array}$ & $0.04 \mathrm{mg} / \mathrm{L}$ & Specific conductance & $1 \mu \mathrm{S} / \mathrm{cm}$ \\
\hline Barium & $0.1 \mu \mathrm{g} / \mathrm{L}$ & $\begin{array}{l}\text { Phosphorus, phosphate, } \\
\text { ortho }\end{array}$ & $0.004 \mathrm{mg} / \mathrm{L}$ & Escherichia coli & $1 \mathrm{col} / 100 \mathrm{~mL}$ \\
\hline Beryllium & $0.01 \mu \mathrm{g} / \mathrm{L}$ & Potassium & $0.03 \mathrm{mg} / \mathrm{L}$ & Methane & $4.97 \mathrm{ng} / \mathrm{kg}$ \\
\hline Calcium & $0.022 \mathrm{mg} / \mathrm{L}$ & Silica & $0.018 \mathrm{mg} / \mathrm{L}$ & Ethyne & $0.0068 \mathrm{ng} / \mathrm{kg}$ \\
\hline Chloride & $0.02 \mathrm{mg} / \mathrm{L}$ & Silver & $1.0 \mu \mathrm{g} / \mathrm{L}$ & Propane & $0.0076 \mathrm{ng} / \mathrm{kg}$ \\
\hline Chromium & $0.5 \mu \mathrm{g} / \mathrm{L}$ & Sodium & $0.06 \mathrm{mg} / \mathrm{L}$ & Propene & $0.0073 \mathrm{ng} / \mathrm{kg}$ \\
\hline Cobalt & $0.03 \mu \mathrm{g} / \mathrm{L}$ & Strontium & $0.2 \mu \mathrm{g} / \mathrm{L}$ & $i$-Butane & $0.0075 \mathrm{ng} / \mathrm{kg}$ \\
\hline Magnesium & $0.011 \mathrm{mg} / \mathrm{L}$ & Uranium & $0.014 \mu \mathrm{g} / \mathrm{L}$ & $n$-Pentane & $0.025 \mathrm{ng} / \mathrm{kg}$ \\
\hline Manganese & $0.4 \mu \mathrm{g} / \mathrm{L}$ & Zinc & $2 \mu \mathrm{g} / \mathrm{L}$ & 2-Methyl-Pentane & $0.025 \mathrm{ng} / \mathrm{kg}$ \\
\hline Mercury & $0.005 \mu \mathrm{g} / \mathrm{L}$ & Alkalinity & $0.1 \mathrm{mg} / \mathrm{L}$ & 3-Methyl-Pentane & $0.025 \mathrm{ng} / \mathrm{kg}$ \\
\hline Molybdenum & $0.05 \mu \mathrm{g} / \mathrm{L}$ & Bicarbonate & $0.1 \mathrm{mg} / \mathrm{L}$ & Hexane & $0.025 \mathrm{ng} / \mathrm{kg}$ \\
\hline Nickel & $0.2 \mu \mathrm{g} / \mathrm{L}$ & Carbonate & $0.1 \mathrm{mg} / \mathrm{L}$ & Benzene & $0.025 \mathrm{ng} / \mathrm{kg}$ \\
\hline Nitrogen, ammonia & $0.01 \mathrm{mg} / \mathrm{L}$ & Dissolved oxygen & $0.1 \mathrm{mg} / \mathrm{L}$ & & \\
\hline
\end{tabular}


concentration, $\mathrm{pH}$, turbidity, hydrogen sulfide gas, and alkalinity were made at the sampling location at the time of sampling. Bacteria samples were collected on site, processed within 2 hours of collection, and incubated overnight according to USGS standard protocols. Hydrogen sulfide gas was measured on site using a Hach hydrogen sulfide test kit (Hach, 2019), using a modified version of EPA Method 376.2, which is a rapid colorimetric reagent-based analytical method (Hach product 223801 method documentation, accessed February 12, 2019, at https://www.hach.com/hydrogen-sulfide-color-disctest-kit-model-hs-wr/product?id=7640219544\&callback=qs). On-site measurement of alkalinity, water temperature, specific conductance, $\mathrm{pH}$, dissolved oxygen, hydrogen sulfide, and field determination of indicator bacteria was required as these constituents can degrade quickly after sample collection.

Dissolved hydrocarbon samples were collected by filling a 1-liter (L) bottle to overflowing in a bucket, submerging the filled water bottle below the water level and then allowing a minimum of three volumes of water to flush through the sample bottle. The bottle was then removed, and three potassium hydroxide preservative tablets were added to the sample and the sample bottle capped and taped shut. Samples were kept chilled in a cooler and then transferred to a refrigerator, prior to shipment to the USGS Dissolved Gas Laboratory in Reston, Virginia.

\section{Analysis of Water Chemistry}

Major ions, nutrients, metals, trace elements, and radon were analyzed using standard EPA or USGS approved methods at the USGS National Water Quality Laboratory in Denver, Colorado. Trace element and common ions, such as calcium, magnesium, sodium, potassium, iron, manganese, sulfate, chloride, bromide, and fluoride were analyzed by Inductively Coupled Plasma mass spectrometry; nutrients (nitrate + nitrite, nitrite, total nitrogen, and orthophosphorus) were analyzed by digestion or colorimetric methods, and radon was analyzed by liquid scintillation methods.

\section{Analysis of Dissolved Hydrocarbons}

Dissolved hydrocarbon concentrations were analyzed by the USGS Dissolved Gas Laboratory in Reston, Virginia. The dissolved $\mathrm{C} 1$ to $\mathrm{C} 6$ hydrocarbons (methane, ethane, ethene, ethyne, propane, propene, propyne, $n$-butane, isobutane, 1-butene, $n$-pentane, isopentane, 2- and 3-methylpentane, hexane, and benzene) were analyzed using specialized purge and trap Gas Chromatography-Flame Ionization Detector and an Atomic Emission Detector (GC-FID/AED). This system uses large-volume water samples to increase sensitivity to trace constituents in picomole range, while maintaining enough dynamic range to enable quantification of samples with considerable amounts of dissolved gas (Haase and others, 2014; Cozzarelli and others, 2017; Orem and others, 2017).
Duplicate samples for dissolved hydrocarbons were collected in 1-L borosilicate glass bottles after being purged with three volumes of water, then capped without headspace using a polyseal cone cap, and preserved with potassium hydroxide pellets and refrigeration to inhibit bacterial activity and to prevent the dissolved gases from volatilizing.

The system was calibrated with a suite of certified gas standards purchased from Air Liquide, LLC (Houston, Texas) with blend accuracies better than 10 percent. Methane was quantified exclusively on the FID detector, as concentrations are typically much higher than the other hydrocarbons. The limit of detection was 4.97 nanograms per kilogram $(\mathrm{ng} / \mathrm{kg})$ and the calibration precision was 0.9 percent relative standard deviation (RSD). The $\mathrm{C} 2$ to $\mathrm{C} 6$ hydrocarbons were simultaneously measured on the AED and the FID, with the reported value coming from the highest sensitivity detector that was still in the range of linearity, which was typically the AED for most measurements of these compounds. The detection limits of the AED are typically in the range $6.75 \times 10^{-3}-25.1 \times 10^{-3} \mathrm{ng} / \mathrm{kg}$, with calibration precisions between 2 and 14 percent, and median percent differences between duplicate samples of 13 to 60 percent.

\section{Geospatial Analysis}

Geospatial analysis for this study was conducted by incorporating all requisite study data into ArcGIS version 10.3.1 (ESRI, 2015). The more important data layers within the ArcGIS Arc-Map project included but were not limited to (1) the points sampled during the course of the project, (2) polygons of mine map extents for both surface and underground mines, (3) structural contours for the major coal seams in the study area, (4) a geologic map showing the surficial geology within the study area, and (5) major geographic features such as locations of public water lines, roads, streams, cities, towns, county boundaries, and land use. Structure contours for coal seams, extent of mining activity, and the geologic map for the study area were all obtained from the WVGES. The primary tasks conducted as part of the spatial analysis were to determine (1) the extent of mining, whether underground or surface in the study area with respect to the sites sampled, and (2) to determine the geologic formation in which the sampled wells were completed. It was important to document the extent of mining and geology surrounding each well sampled as those were the primary objectives of the study.

\section{Quality Assurance and Quality Control}

Three types of quality-assurance and quality-control (QA/QC) samples were collected during the course of the study: replicates, field blanks, and equipment blanks. Replicates were run on environmental samples to assess the reproducibility of analytical methods and assess bias that may result 
due to laboratory analysis. Field blanks were run to assess any contamination that may result from field sampling methods, to evaluate decontamination procedures between sites, and to detect contamination on sampling equipment during transit to and from the sampling site. Equipment blanks were generally run in the laboratory at the USGS Water Science Center in Charleston, West Virginia, and were run to assess the potential of contamination from blank water used to process field and equipment blanks, the deionized water and liquinox detergent solutions used to decontaminate equipment between sampling sites, and to assess whether residual contamination was being carried over from site to site.

Variability for a replicate sample pair was quantified by calculating the relative percent difference (RPD) of the samples. The RPD was calculated using the following formula:

$$
\left.\left[\left|\mathrm{R}_{1}-\mathrm{R}_{2}\right| /\left(\mathrm{R}_{1}+\mathrm{R}_{2}\right) / 2\right)\right] \times 100,
$$

where $R_{1}$ is the concentration of the analyte in the first replicate sample and $R_{2}$ is the concentration of the analyte in the second replicate sample. Concentrations of replicate sample pairs differed by small amounts, typically less than 15 percent of the RPD.

\section{Statistical and Graphical Analysis}

Statistical and graphical techniques were used to summarize and compare water chemistry and field parameters among different sites according to spatial location, geology, site type, and topographic setting. Statistical analyses were conducted, and graphics were created using the R statistical computing environment version 3.4.0 (R Core Team, 2017). Non-parametric techniques were used for computing descriptive and multivariate statistics from water-quality data that were in some instances censored at multiple levels. Censored data are low-level concentrations of chemicals with values that range between zero and the laboratory's reporting limit. The robust regression on order statistics (ROS) survival analysis method was used to calculate summary statistics for censored data because of the relatively small sample sizes, and to avoid transformation bias of non-normal water-quality data (Helsel, 2012). Scatter plots were used to understand the relation between ion concentrations, mineral SIs, and $\mathrm{pH}$. Tukey-type boxplots, censored at the highest reporting limit (Lorenz, 2018), were created to understand the relation between waterquality and site characteristics whereas trilinear Piper diagrams (Back, 1966; Piper, 1944) were used to show a graphical representation of major ion chemistry. Boxplots and Piper diagrams were created with the USGS smwrGraphs package and when necessary, the robust ROS method was employed to impute values for censored water-quality data (Lorenz and Diekoff, 2017).

Prior to multivariable statistical analysis, and because of the presence of multiple censoring levels, censored data were re-coded to u-Scores with the codeU function in the USGS smwrQW package (Lorenz, 2018). The u-Score is the sum of the sign of the differences between each value and all other values and is equivalent to the rank but scaled so the median is equal to zero. Using u-Scores allows for the computation of multivariate relations without requiring censoring at the highest reporting limit and retains information at multiple reporting limits. In cases where a column of data has only one censoring level, the u-Scores are the same as ordinal methods of ranking for one reporting limit (Helsel, 2012).

Principal components analysis (PCA) was used to identify the major chemical and hydrological processes that could explain dissolved element concentrations in the water-quality dataset. PCA was computed with the principal function in the R psych package (Revelle, 2019), which first computes correlation coefficients (Spearman's rho) for the raw u-Scores and then performs a PCA on the resulting correlation matrix. Varimax rotation was applied to simplify the structure of the PCA model, which maximized the differences in components and aided in the interpretation of results. Water-quality variables that had missing values or were censored in more than 40 percent of the values were excluded from the PCA. The variable loadings from the varimax-rotated PCA were used to determine the master variables for each rotated component. Resulting loadings from the PCA and significant correlations $(p<0.001)$ from the correlation matrix were retained and used for further interpretation of the dataset.

To assess whether there were statistical differences between the quality of water derived from (1) the various geologic formations, (2) the type of site (well compared to outfall), (3) the topographic setting (uplands compared to valleys), and (4) the predominant type of mining (northwestern surface-mine-dominated region and southeastern underground-mine-dominated part of the study area), Wilcoxon signed-rank tests (Helsel, 2012) were run for the various populations using the open-source code statistical software R.

\section{Geochemical Modeling}

Aqueous speciation and mineral SIs were computed with the geochemical modeling software PHREEQC (Parkhurst and Appelo, 2013). The mineral SI is a measure of whether a mineral has the potential to dissolve or precipitate depending on the conditions of the solution. It is determined by dividing the ion activity product (IAP) by the thermodynamic solubility product $\left(K_{\mathrm{sp}}\right)$ and then taking the logarithm of the quotient. When a solution is at equilibrium, the SI is zero. In solutions where the SI is above zero (IAP is greater than $K_{\mathrm{sp}}$ ), the solution is said to be supersaturated and the specified mineral, if present, is not likely to dissolve. In solutions where the SI is below zero (IAP is less than $K_{\text {sp }}$ ), the solution is said to be undersaturated and the mineral, if present, could potentially dissolve and not precipitate (Benjamin, 2002). 


\section{Groundwater Quality}

Groundwater quality within this report is discussed with respect to several criteria. First, QA data are important in assessing the quality of the data on which data summaries and analyses are based. QA data help to evaluate potential bias in the data resulting from contamination as part of sampling and decontamination processes between sample sites, laboratory variability in analytical methods, and other potential contamination that may affect the sample collection and analytical process.

Second, although residential wells and mine outfalls are unregulated, water-quality data collected for this study can be related to drinking-water standards to document the quality of groundwater that is typically being used for rural residential supply in southern West Virginia. These criteria provide residents of the region and State and local water-resources managers valuable information on constituents that may be of concern with respect to health-based or aesthetic standards.

Third, criteria such as topographic setting, whether a well or outfall is situated in a hilltop, hillside, or valley setting, and well-construction characteristics, such as depth of wells and length of cased intervals, can also be evaluated to address issues with respect to groundwater quality. Sampling in the region from previous studies has shown that groundwater age for hilltop, hillside, and valley settings is typically on the order of approximately 13, 29, and 42 years, respectively (Sheets and Kozar, 2000). Longer residence time, which generally is correlated with topographic setting, gives groundwater more time to interact with minerals in the bedrock, potentially affecting groundwater quality.

Similarly, the depth of wells and lengths of well casings can also affect groundwater quality, as deeper wells and wells with longer casings typically contain lower dissolved oxygen levels than shallow wells or wells with short casings. Dissolved oxygen or the lack thereof is a primary factor controlling redox processes in groundwater. As a result, shallower wells less than $100 \mathrm{ft}$ deep tend to have higher concentrations of iron and manganese (300 and $130 \mathrm{mg} / \mathrm{L}$, respectively) than deeper wells ( 35 and $9 \mathrm{mg} / \mathrm{L}$, respectively) greater than $300 \mathrm{ft}$ deep (Mathes and others, 1998).

Finally, the major classes of constituents are discussed. The first class of constituents is field measurements of $\mathrm{pH}$, dissolved oxygen, specific conductance, turbidity, and alkalinity. The second class of constituents is major ions including, but not limited to, calcium, magnesium, sodium, potassium, chloride, bromide, fluoride, silica, sulfate, and sodium. The third class of constituents is nutrients, including nitrate, nitrite, ammonia, and orthophosphate. The fourth class of constituents is the indicator bacteria total coliform and E. coli. The fifth class of constituents is metals and trace elements including, but not limited to, iron, manganese, silver, copper, lead, chromium, cobalt, nickel, barium, mercury, nickel, arsenic, and selenium. The sixth class of constituents is radioactive elements radon and uranium. The seventh class of constituents is hydrogen sulfide gas and dissolved hydrocarbons including, but not limited to, methane, ethane, pentane, butane, propane, hexane, and benzene.

All water-quality data collected for this study and reported here (excluding the dissolved hydrocarbon data) are publicly available from the USGS NWIS database (https:// waterdata.usgs.gov/nwis/qw; U.S. Geological Survey, 2018b). The dissolved hydrocarbon data collected for this study data are publicly available as a USGS data release (Haase and others, 2018). The dissolved hydrocarbon data were published as part of a data release summarizing data for several concurrent USGS studies to document dissolved hydrocarbon occurrence and distribution for various aquifers within the midwestern and northeastern parts of the United States (Haase and other, 2018). A list of all the sites sampled for the study, including the date and time of sampling, the type of site (well or mine outfall), coal-field region (eastern or western), applicable USGS station numbers and site names, and well-construction information is provided in table 2 .

\section{Quality-Assurance Results}

Analyte concentrations of replicate sample pairs typically differed by small amounts, less than 15 percent RPD. The few constituents that exceeded the 15-percent RPD threshold were for concentrations just above the method detection limit. This was the case for several common ions and trace metals including fluoride (1 of 2 replicate pairs with a RPD of 18.2 percent), beryllium ( 1 of 2 replicate pairs with a RPD of 36.7 percent), iron ( 1 of 2 replicate pairs with a RPD of 20.8 percent), molybdenum ( 1 of 2 replicate pairs with a RPD of 28.3 percent), and silver ( 1 of 2 replicate pairs with a RPD of 62.1 percent). This was also the case for the radionuclides, radon ( 1 of 1 replicate pair with a RPD of 19.6 percent) and uranium ( 1 of 2 replicate pairs with a RPD of 40.0 percent). The RPDs of the remaining 36 constituents analyzed generally were less than 5 percent RPD.

Field-blank values for two samples generally were less than the method detection limit, indicating that field collection and processing procedures for samples and decontamination of equipment between sites were adequate to prevent cross contamination of environmental samples collected for the study. For one of the field blanks, none of the 43 constituents analyzed were detected; for the second field blank, only 3 constituents had detectable concentrations of an analyte, and all 3 constituents were just above the method detection limit. Silica was detected in the one field blank sample at a concentration of $0.025 \mathrm{mg} / \mathrm{L}$ (method detection limit was $0.018 \mathrm{mg} / \mathrm{L}$ ), ammonia as $\mathrm{N}$ was detected at a concentration of $0.011 \mathrm{mg} / \mathrm{L}$ (method detection limit was $0.013 \mathrm{mg} / \mathrm{L}$ ), and 


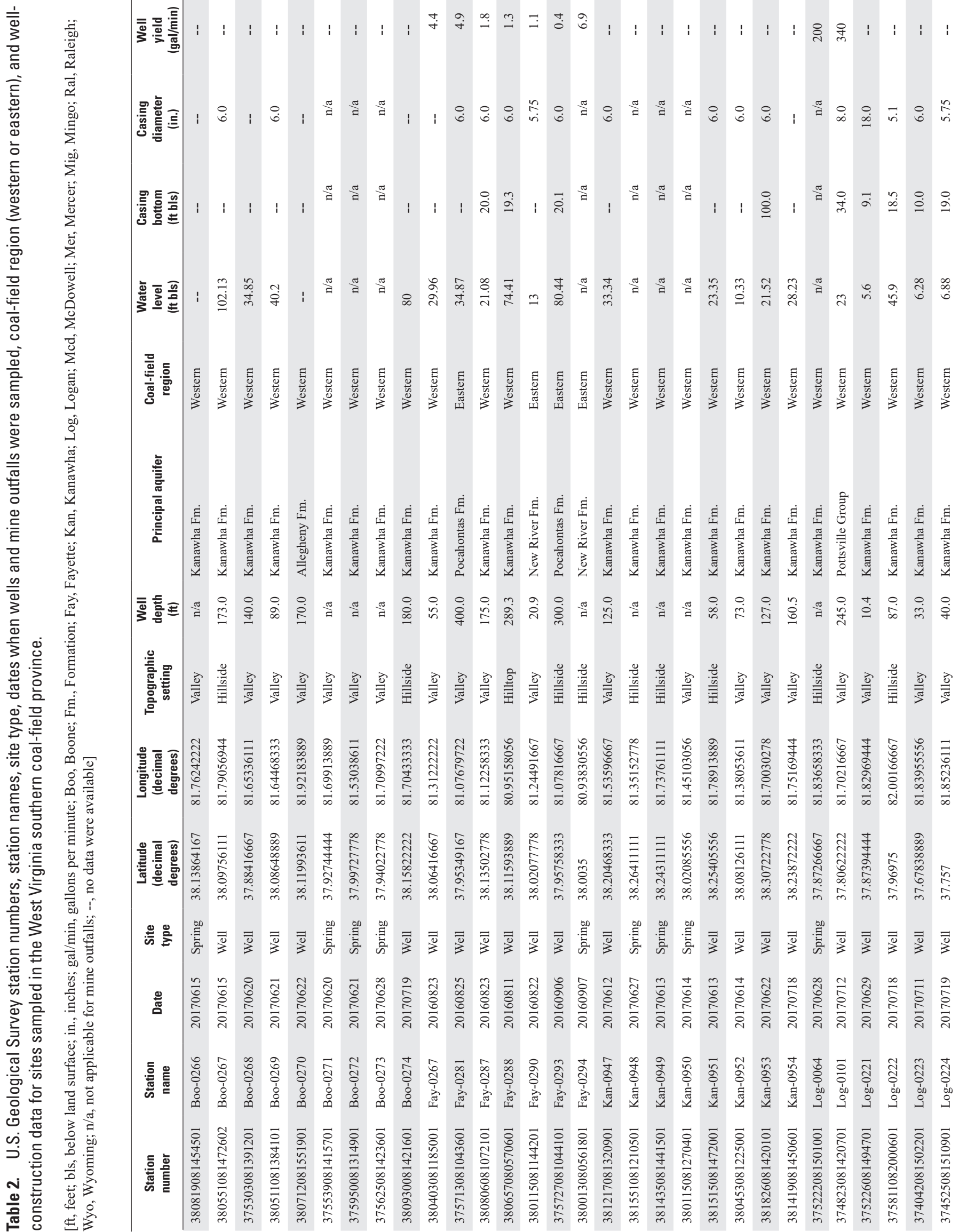




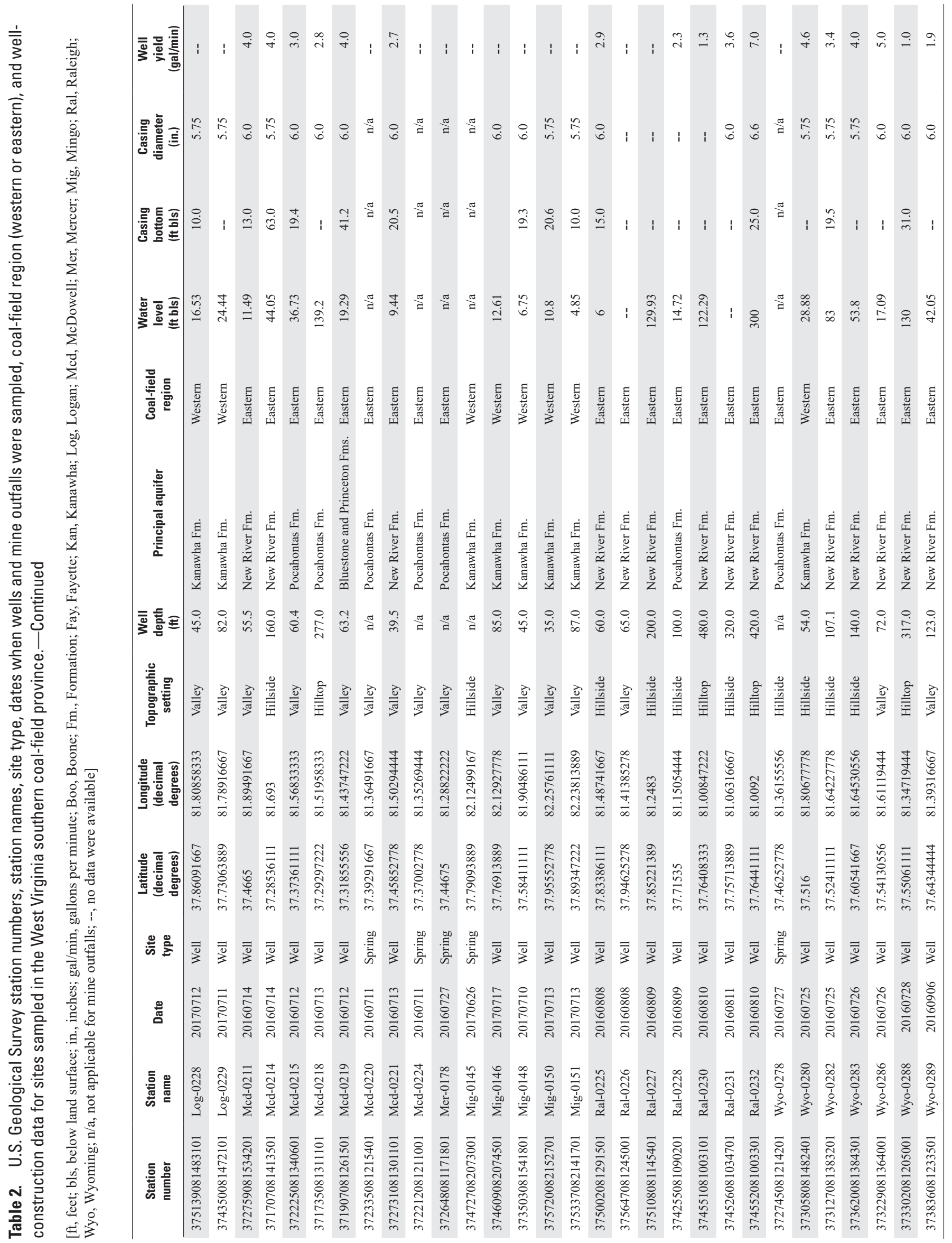


copper was detected at a concentration of $0.202 \mu \mathrm{g} / \mathrm{L}$ (method detection limit was $0.2 \mu \mathrm{g} / \mathrm{L}$ ).

Equipment blank data are QA samples collected in a controlled laboratory environment to assess the cleanliness of the equipment used, to test the quality of the blank water for the field and laboratory blanks, and to assess laboratory analytical bias. The blank data also generally indicated that there was minimal contamination of equipment or error associated with the quality of blank water or laboratory analytical procedures. Data for one of the equipment blanks contained no detectable concentrations for 42 of the 43 constituents analyzed, but had a low-level detection of ammonia as $\mathrm{N}$ at a concentration of $0.014 \mathrm{mg} / \mathrm{L}$. The second equipment blank contained low-level detections for five constituents, all just at or slightly above the method detection limit. For this second blank sample, silica was detected at a concentration of $0.024 \mathrm{mg} / \mathrm{L}$ (method detection limit was $0.018 \mathrm{mg} / \mathrm{L}$ ), ammonia as $\mathrm{N}$ was detected at a concentration of $0.011 \mathrm{mg} / \mathrm{L}$ (method detection limit was $0.013 \mathrm{mg} / \mathrm{L}$ ), lead was detected at a concentration of $0.022 \mu \mathrm{g} / \mathrm{L}$ (method detection limit was $0.02 \mu \mathrm{g} / \mathrm{L}$ ), molybdenum was detected at a concentration of $0.052 \mu \mathrm{g} / \mathrm{L}$ (method detection limit was $0.05 \mu \mathrm{g} / \mathrm{L}$ ), and nickel was detected at a concentration of $0.29 \mu \mathrm{g} / \mathrm{L}$ (method detection limit was $0.02 \mu \mathrm{g} / \mathrm{L}$ ). Concentrations for the remaining 38 constituents analyzed for the second lab blank were all less than detection limits.

Only 1 of the 60 sites sampled had a concentration of ammonia as $\mathrm{N}(0.010 \mathrm{mg} / \mathrm{L})$ comparable to the 0.010 to $0.014 \mathrm{mg} / \mathrm{L}$ bias documented in the field or laboratory blanks, so overall bias with respect to ammonia contamination was minimal. The minimum concentration of silica detected at the 60 sites sampled was $5.746 \mathrm{mg} / \mathrm{L}$, far above the 0.024 and $0.025 \mathrm{mg} / \mathrm{L}$ detected in the 1 equipment blank and 1 field blank. Of the 60 sites sampled, 28 sites had concentrations of copper less than the method detection limit of $0.2 \mu \mathrm{g} / \mathrm{L}$ and the $0.20 \mu \mathrm{g} / \mathrm{L}$ concentration detected in 1 field blank, and 3 additional sites had concentrations of copper of $0.20,0.21$, and $0.23 \mu \mathrm{g} / \mathrm{L}$, so there is a possibility of some bias with respect to low-level detections for copper. Likewise, for nickel, 14 of 60 sites sampled had concentrations of nickel less than the method detection limit of $0.2 \mu \mathrm{g} / \mathrm{L}$ and the $0.29 \mu \mathrm{g} / \mathrm{L}$ detected in 1 equipment blank, and 5 additional sites had nickel concentrations of $0.20,0.21,0.210 .22$, and $0.24 \mu \mathrm{g} / \mathrm{L}$, so some bias with respect to low-level concentrations of nickel also is possible. For molybdenum, 20 of the 60 sites sampled had concentrations less than the method detection limit of $0.05 \mu \mathrm{g} / \mathrm{L}$, and 8 additional sites had low-level concentrations of molybdenum at concentrations of $0.052,0.06,0.07$, $0.08,0.081,0.086,0.09$, and $0.091 \mu \mathrm{g} / \mathrm{L}$. Therefore, bias with respect to low-level concentrations of molybdenum also is possible. Finally, 34 of the 60 sites sampled had concentrations of lead less than the method detection limit of 0.02 to $0.04 \mu \mathrm{g} / \mathrm{L}$, and an additional 9 sites had lead concentrations less than $0.10 \mu \mathrm{g} / \mathrm{L}$. Of all the constituents that were detected in either field or equipment blanks, lead showed the most potential bias.

\section{Groundwater Quality in Relation to Drinking- Water Standards}

A primary impetus for this study was concern that trace metals or other contaminants present in unregulated water sources from residential wells and mine outfalls may pose a health threat to individuals that rely on these sources for their water supply. As a result, groundwater-quality data collected for this study are related to public drinking-water standards, even though those regulations are not enforceable for domestic rural-residential water supplies.

Analyte concentrations are compared to several drinkingwater standards (table $3 A$ ) including EPA MCLs, Maximum Contaminant Level Goals (MCLGs), health-based values (HBVs), treatment technique (TT) standard for turbidity, proposed MCL and alternate proposed maximum contaminant level (AMCL) for radon and drinking-water equivalent levels (DWELs). Full descriptions of EPA drinking-water standards and health advisories may be accessed (U.S. Environmental Protection Agency, 2019a) at the EPA web site (accessed February 12, 2019, at https://www.epa.gov/ dwstandardsregulations). USGS health-based screening levels (HBSLs) and the U.S. Office of Surface Mining Reclamation and Enforcement level of concern (LOC) and immediate action level (IAL) for methane in groundwater also are provided to assess the overall quality of groundwater in the study area. The EPA HBV of $20 \mathrm{mg} / \mathrm{L}$ for sodium for those on a sodium-restricted diet also is included. Full descriptions of the USGS HBSLs given by Norman and others (2018) are publicly available online at the USGS Health-Based Screening Levels web site (accessed February 12, 2019, at https:// cida.usgs.gov/hbsl/apex/f?p=104:1:). SMCLs are standards that relate to aesthetic issues rather than health-based criteria, such as color, odor, taste, and staining of plumbing fixtures. EPA regulations (U.S. Environmental Protection Agency, $2019 b$ ) for public water systems that use conventional or direct filtration, state that at no time can turbidity (cloudiness of water) go higher than 1 Nephelometric Turbidity Unit (NTU), and samples for turbidity must be less than or equal to 0.3 NTUs in at least 95 percent of the samples in any month. The regulations also state that systems that use filtration other than the conventional or direct filtration technique must follow state limits, which must include turbidity at no time exceeding 5 NTUs. EPA drinking-water standards are established for public drinking-water systems and are not enforceable for residential water supplies, but provide a guide for residential homeowners to assess turbidity levels in their well water (accessed June 7, 2019, at https://safewater.zendesk.com/hc/ en-us/sections/202346167). In this report, EPA turbidity standards are reported in NTU, but the method the USGS commonly uses for field measurement of turbidity reports turbidity in Nephelometric Turbidity Ratio Units (NTRU). However, NTRU and NTU are equivalent for comparison purposes. Boxplots showing the distribution of some of the constituents that exceeded one or more of the drinking-water standards in 10 percent or more of the sites sampled are shown in figure 6 . 
Table 3A. Summary table of U.S. Environmental Protection Agency (EPA) drinking-water standards, U.S. Geological Survey (USGS) health-based screening levels, and U.S. Office of Surface Mining Reclamation and Enforcement (OSMRE) level of concern and immediate action level for methane in groundwater.

[SMCL, secondary maximum contaminant level; MCLG, maximum contaminant level goal; MCL, maximum contaminant level; TT, treatment technique; AMCL, alternate maximum contaminant level; LOC, level of concern; IAL, immediate action level; HBSL, health-based screening level; HBV, health-based value; DWEL, drinking-water equivalent level; kg, kilogram; HAL, health advisory level; NTU, nephelometric turbidity units; TDS, total dissolved solids; $\mathrm{mg} / \mathrm{L}$, milligrams per liter; N, nitrogen; E. coli, Escherichia coli; MPN, most probable number; $\mathrm{mL}$, milliliters; $\mu \mathrm{g} / \mathrm{L}$, micrograms per liter; $\mathrm{pCi} / \mathrm{L}$, picocuries per liter; $\mathrm{mg} / \mathrm{kg}$, milligrams per kilogram; \%, percent; --, no applicable standards for that constituent from the respective agency]

Drinking water standard

\begin{tabular}{|c|c|c|c|c|c|c|c|c|c|c|}
\hline Constituent (unit) & 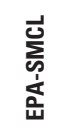 & 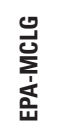 & $\begin{array}{l}\frac{d}{\sum_{j}} \\
\frac{i}{\Delta}\end{array}$ & 卢 & 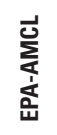 & 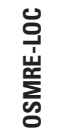 & 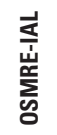 & 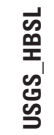 & 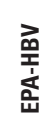 & 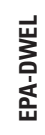 \\
\hline
\end{tabular}

\begin{tabular}{|c|c|c|c|c|c|c|c|c|c|c|c|}
\hline pH (standard units) & $6.5-8.5$ & -- & -- & -- & -- & -- & -- & -- & -- & -- & -- \\
\hline TDS (mg/L) & $500 \mathrm{mg} / \mathrm{L}$ & -- & -- & -- & -- & -- & -- & -- & -- & -- & -- \\
\hline Sodium (mg/L) & -- & -- & -- & -- & -- & -- & -- & -- & $20 \mathrm{mg} / \mathrm{L}$ & -- & -- \\
\hline Fluoride $(\mathrm{mg} / \mathrm{L})$ & $2.0 \mathrm{mg} / \mathrm{L}$ & $4 \mathrm{mg} / \mathrm{L}$ & $4 \mathrm{mg} / \mathrm{L}$ & -- & -- & -- & -- & -- & -- & -- & -- \\
\hline Sulfate $(\mathrm{mg} / \mathrm{L})$ & $250 \mathrm{mg} / \mathrm{L}$ & -- & -- & -- & -- & -- & -- & -- & $500 \mathrm{mg} / \mathrm{L}$ & -- & -- \\
\hline${ }^{2}$ Hydrogen sulfide $(\mathrm{mg} / \mathrm{L}$ ) & $0.05 \mathrm{mg} / \mathrm{L}$ & -- & -- & -- & -- & -- & -- & -- & -- & -- & -- \\
\hline Nitrite as $N(\mathrm{mg} / \mathrm{L})$ & -- & $1 \mathrm{mg} / \mathrm{L}$ & $1 \mathrm{mg} / \mathrm{L}$ & -- & -- & -- & -- & -- & -- & -- & $1 \mathrm{mg} / \mathrm{L}$ \\
\hline${ }^{3} E . \operatorname{coli}(\mathrm{MPN} / 100 \mathrm{~mL})$ & -- & 0 & $5 \% /$ month & -- & -- & -- & -- & -- & -- & -- & -- \\
\hline${ }^{3}$ Total coliform (MPN/100 mL) & -- & 0 & $5 \% /$ month & -- & -- & -- & -- & -- & -- & -- & -- \\
\hline Aluminum $(\mu \mathrm{g} / \mathrm{L})$ & $0.05-2.0 \mu \mathrm{g} / \mathrm{L}$ & -- & -- & -- & -- & -- & -- & -- & -- & -- & -- \\
\hline Barium $(\mu \mathrm{g} / \mathrm{L})$ & -- & $2,000 \mu \mathrm{g} / \mathrm{L}$ & $2,000 \mu \mathrm{g} / \mathrm{L}$ & -- & -- & -- & -- & -- & -- & $7,000 \mu \mathrm{g} / \mathrm{L}$ & -- \\
\hline Beryllium $(\mu \mathrm{g} / \mathrm{L})$ & -- & $4 \mu \mathrm{g} / \mathrm{L}$ & $4 \mu \mathrm{g} / \mathrm{L}$ & -- & -- & -- & -- & -- & -- & $70 \mu \mathrm{g} / \mathrm{L}$ & -- \\
\hline${ }^{4} \operatorname{Lead}(\mu \mathrm{g} / \mathrm{L})$ & -- & $0 \mu \mathrm{g} / \mathrm{L}$ & -- & $15 \mu \mathrm{g} / \mathrm{L}$ & -- & -- & -- & -- & -- & -- & -- \\
\hline Manganese $(\mu \mathrm{g} / \mathrm{L})$ & $50 \mu \mathrm{g} / \mathrm{L}$ & -- & -- & -- & -- & -- & -- & $300 \mu \mathrm{g} / \mathrm{L}$ & -- & $1,600 \mu \mathrm{g} / \mathrm{L}$ & -- \\
\hline Mercury $(\mu \mathrm{g} / \mathrm{L})$ & -- & $2 \mu \mathrm{g} / \mathrm{L}$ & $2 \mu \mathrm{g} / \mathrm{L}$ & -- & -- & -- & -- & -- & -- & $10 \mu \mathrm{g} / \mathrm{L}$ & -- \\
\hline Molybdenum $(\mu \mathrm{g} / \mathrm{L})$ & -- & -- & -- & -- & -- & -- & -- & $40 \mu \mathrm{g} / \mathrm{L}$ & -- & $200 \mu \mathrm{g} / \mathrm{L}$ & -- \\
\hline Nickel $(\mu \mathrm{g} / \mathrm{L})$ & -- & -- & -- & -- & -- & -- & -- & $100 \mu \mathrm{g} / \mathrm{L}$ & -- & $700 \mu \mathrm{g} / \mathrm{L}$ & -- \\
\hline Silver $(\mu \mathrm{g} / \mathrm{L})$ & $100 \mu \mathrm{g} / \mathrm{L}$ & -- & -- & -- & -- & -- & -- & $100 \mu \mathrm{g} / \mathrm{L}$ & -- & $200 \mu \mathrm{g} / \mathrm{L}$ & $200 \mu \mathrm{g} / \mathrm{L}$ \\
\hline Zinc $(\mu \mathrm{g} / \mathrm{L})$ & $5,000 \mu \mathrm{g} / \mathrm{L}$ & -- & -- & -- & -- & -- & -- & $2,000 \mu \mathrm{g} / \mathrm{L}$ & -- & $10,000 \mu \mathrm{g} / \mathrm{L}$ & $6,000 \mu \mathrm{g} / \mathrm{L}$ \\
\hline Antimony $(\mu \mathrm{g} / \mathrm{L})$ & -- & $6 \mu \mathrm{g} / \mathrm{L}$ & $6 \mu \mathrm{g} / \mathrm{L}$ & -- & -- & -- & -- & -- & -- & $10 \mu \mathrm{g} / \mathrm{L}$ & -- \\
\hline Arsenic $(\mu \mathrm{g} / \mathrm{L})$ & -- & $0 \mu \mathrm{g} / \mathrm{L}$ & $10 \mu \mathrm{g} / \mathrm{L}$ & -- & -- & -- & -- & -- & -- & $10 \mu \mathrm{g} / \mathrm{L}$ & -- \\
\hline Selenium $(\mu \mathrm{g} / \mathrm{L})$ & -- & $50 \mu \mathrm{g} / \mathrm{L}$ & $50 \mu \mathrm{g} / \mathrm{L}$ & -- & -- & -- & -- & -- & -- & $200 \mu \mathrm{g} / \mathrm{L}$ & -- \\
\hline${ }^{5} \operatorname{Radon}(\mathrm{pCi} / \mathrm{L})$ & -- & -- & $300 \mathrm{pCi} / \mathrm{L}$ & -- & $4,000 \mathrm{pCi} / \mathrm{L}$ & -- & -- & -- & -- & -- & -- \\
\hline Uranium $(\mu \mathrm{g} / \mathrm{L})$ & -- & $0 \mu \mathrm{g} / \mathrm{L}$ & $30 \mu \mathrm{g} / \mathrm{L}$ & -- & -- & -- & -- & -- & -- & -- & -- \\
\hline Methane $(\mathrm{mg} / \mathrm{kg})$ & -- & -- & -- & -- & -- & $10 \mathrm{mg} / \mathrm{kg}$ & $28 \mathrm{mg} / \mathrm{kg}$ & -- & -- & -- & -- \\
\hline
\end{tabular}

${ }^{1}$ For systems that use conventional or direct filtration, at no time can turbidity (cloudiness of water) go higher than 1 Nephelometric Turbidity Unit (NTU), and samples for turbidity must be less than or equal to 0.3 NTUs in at least 95 percent of the samples in any month. Systems that use filtration other than the conventional or direct filtration must follow State limits, which must include turbidity at no time exceeding 5 NTUs.

${ }^{2}$ There are no drinking water standards for hydrogen sulfide gas, but the odor threshold at which the human nose can smell hydrogen sulfide gas is $0.05 \mathrm{mg} / \mathrm{L}$.

${ }^{3}$ For public water systems no more than 5.0 percent samples total coliform-positive (TC-positive) in a month. (For water systems that collect fewer than 40 routine samples per month, no more than one sample can be total coliform-positive per month.) Every sample that has total coliform must be analyzed for either fecal coliforms or $E$. coli if two consecutive TC-positive samples, and one is also positive for $E$. coli fecal coliforms, system has an acute MCL violaton.

${ }^{4}$ Lead and copper are regulated by a Treatment Technique that requires systems to control the corrosiveness of their water. If more than 10 percent of tap water samples exceed the action level, water systems must take additional steps. For copper, the action level is $1,300 \mu \mathrm{g} / \mathrm{L}$, and for lead is $15 \mu \mathrm{g} / \mathrm{L}$.

${ }^{5}$ In 1999 the EPA proposed an MCL of $300 \mathrm{pCi} / \mathrm{L}$ for radon in drinking water, and to date the rule has yet to be finalized. Therefore the MCL for radon is referenced as a proposed standard. An alternate MCL (AMCL) for radon was proposed for public water systems that initiated a radon mitigation program. Additional information on radon may be found at https://archive.epa.gov/water/archive/web/html/regulations.html. 
Table 3B. Summary table of U.S. Environmental Protection Agency (EPA) drinking-water standards, U.S. Geological Survey (USGS) health-based screening levels, and U.S. Office of Surface Mining Reclamation and Enforcement (OSMRE) level of concern and immediate action level for methane in groundwater, applied to water-quality data from this report.

[SMCL, secondary maximum contaminant level; MCLG, maximum contaminant level goal; MCL, maximum contaminant level; TT, treatment technique; AMCL, alternate maximum contaminant level; LOC, level of concern; IAL, immediate action level; HBSL, health-based screening level; HBV, health-based value; DWEL, drinking-water equivalent level; kg, kilogram; HAL, health advisory level; NTU, nephelometric turbidity units; TDS, total dissolved solids; $\mathrm{mg} / \mathrm{L}$, milligrams per liter; N, nitrogen; E. coli, Escherichia coli; MPN, most probable number; $\mathrm{mL}$, milliliters; $\mu \mathrm{g} / \mathrm{L}$, micrograms per liter; pCi/L, picocuries per liter; mg/kg, milligrams per kilogram; \%, percent; --, no applicable standards for that constituent from the respective agency]

Water-quality samples exceeding drinking water standard (count/percentage)

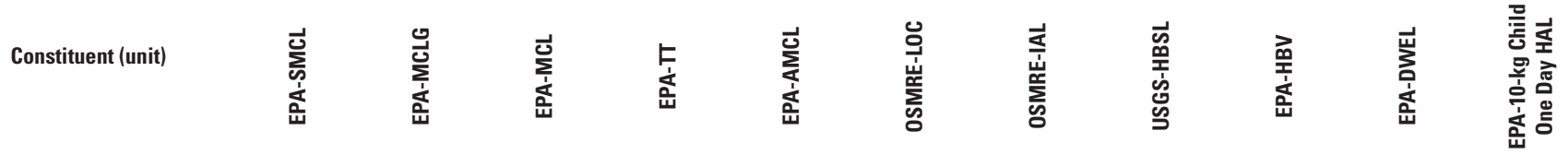

\begin{tabular}{|c|c|c|c|c|c|c|c|c|c|c|c|}
\hline pH (standard units) & $31 / 51.7 \%$ & -- & -- & -- & -- & -- & -- & -- & -- & -- & -- \\
\hline${ }^{1}$ Turbidity (NTU) & -- & -- & -- & $51 / 85 \%$ & -- & -- & -- & -- & -- & -- & -- \\
\hline${ }^{1}$ Turbidity (NTU) & -- & -- & -- & $14 / 23.3 \%$ & -- & -- & -- & -- & -- & -- & -- \\
\hline TDS (mg/L) & $6 / 10 \%$ & -- & -- & -- & -- & -- & -- & -- & -- & -- & -- \\
\hline Sodium (mg/L) & -- & -- & -- & -- & -- & -- & -- & -- & $27 / 45 \%$ & -- & -- \\
\hline Chloride (mg/L) & $2 / 3.3 \%$ & -- & -- & -- & -- & -- & -- & -- & -- & -- & -- \\
\hline Fluoride (mg/L) & $1 / 1.7 \%$ & $0 / 0 \%$ & $0 / 0 \%$ & -- & -- & -- & -- & -- & -- & -- & -- \\
\hline Sulfate $(\mathrm{mg} / \mathrm{L})$ & $2 / 3.3 \%$ & -- & -- & -- & -- & -- & -- & -- & $1 / 1.7 \%$ & -- & -- \\
\hline${ }^{2}$ Hydrogen sulfide (mg/L) & $5 / 8.5 \%$ & -- & -- & -- & -- & -- & -- & -- & -- & -- & -- \\
\hline Ammonia as $\mathrm{N}(\mathrm{mg} / \mathrm{L})$ & -- & -- & -- & -- & -- & -- & -- & -- & $0 / 0 \%$ & -- & -- \\
\hline Nitrate as N (mg/L) & -- & $0 / 0 \%$ & $0 / 0 \%$ & -- & -- & -- & -- & -- & -- & -- & $0 / 0 \%$ \\
\hline Nitrite as N (mg/L) & -- & $0 / 0 \%$ & $0 / 0 \%$ & -- & -- & -- & -- & -- & -- & -- & $0 / 0 \%$ \\
\hline${ }^{3} E$. coli $(\mathrm{MPN} / 100 \mathrm{~mL})$ & -- & $14 / 23.3 \%$ & $14 / 23.3 \%$ & -- & -- & -- & -- & -- & -- & -- & -- \\
\hline${ }^{3}$ Total coliform $(\mathrm{MPN} / 100 \mathrm{~mL})$ & -- & $39 / 65 \%$ & $39 / 65 \%$ & -- & -- & -- & -- & -- & -- & -- & -- \\
\hline Aluminum $(\mu \mathrm{g} / \mathrm{L})$ & $8 / 13.3 \%$ & -- & -- & -- & -- & -- & -- & -- & -- & -- & -- \\
\hline $\operatorname{Barium}(\mu \mathrm{g} / \mathrm{L})$ & -- & $2 / 3.3 \%$ & $2 / 3.3 \%$ & -- & -- & -- & -- & -- & -- & $0 / 0 \%$ & -- \\
\hline Beryllium $(\mu \mathrm{g} / \mathrm{L})$ & -- & $1 / 1.7 \%$ & $1 / 1.7 \%$ & -- & -- & -- & -- & -- & $0 / 0 \%$ & $0 / 0 \%$ & -- \\
\hline Cadmium $(\mu \mathrm{g} / \mathrm{L})$ & -- & $0 / 0 \%$ & $0 / 0 \%$ & -- & -- & -- & -- & $0 / 0 \%$ & -- & $0 / 0 \%$ & -- \\
\hline Chromium $(\mu \mathrm{g} / \mathrm{L})$ & -- & $0 / 0 \%$ & $0 / 0 \%$ & -- & -- & -- & -- & $0 / 0 \%$ & -- & $0 / 0 \%$ & -- \\
\hline${ }^{4}$ Copper $(\mu \mathrm{g} / \mathrm{L})$ & $0 / 0 \%$ & $0 / 0 \%$ & -- & $0 / 0 \%$ & -- & -- & -- & -- & -- & -- & -- \\
\hline Iron $(\mu \mathrm{g} / \mathrm{L})$ & $25 / 41.7 \%$ & -- & -- & -- & -- & -- & -- & -- & -- & -- & -- \\
\hline${ }^{4}$ Lead $(\mu \mathrm{g} / \mathrm{L})$ & -- & $25 / 41.7 \%$ & -- & $0 / 0 \%$ & -- & -- & -- & -- & -- & -- & -- \\
\hline Manganese $(\mu \mathrm{g} / \mathrm{L})$ & $30 / 50 \%$ & -- & -- & -- & -- & -- & -- & $14 / 23.3 \%$ & -- & $1 / 1.7 \%$ & -- \\
\hline Mercury $(\mu \mathrm{g} / \mathrm{L})$ & -- & $0 / 0 \%$ & $0 / 0 \%$ & -- & -- & -- & -- & -- & -- & $0 / 0 \%$ & -- \\
\hline Molybdenum $(\mu \mathrm{g} / \mathrm{L})$ & -- & -- & -- & -- & -- & -- & -- & $0 / 0 \%$ & -- & $0 / 0 \%$ & -- \\
\hline Nickel $(\mu \mathrm{g} / \mathrm{L})$ & -- & -- & -- & -- & -- & -- & -- & $1 / 1.7 \%$ & -- & $0 / 0 \%$ & -- \\
\hline Silver $(\mu \mathrm{g} / \mathrm{L})$ & $0 / 0 \%$ & -- & -- & -- & -- & -- & -- & $0 / 0 \%$ & -- & $0 / 0 \%$ & $0 / 0 \%$ \\
\hline Zinc $(\mu \mathrm{g} / \mathrm{L})$ & $0 / 0 \%$ & -- & -- & -- & -- & -- & -- & $0 / 0 \%$ & -- & $0 / 0 \%$ & $0 / 0 \%$ \\
\hline Antimony $(\mu \mathrm{g} / \mathrm{L})$ & -- & $0 / 0 \%$ & $0 / 0 \%$ & -- & -- & -- & -- & -- & -- & $0 / 0 \%$ & -- \\
\hline Arsenic $(\mu \mathrm{g} / \mathrm{L})$ & -- & $32 / 53.3 \%$ & $0 / 0 \%$ & -- & -- & -- & -- & -- & -- & $0 / 0 \%$ & -- \\
\hline Selenium $(\mu \mathrm{g} / \mathrm{L})$ & -- & $0 / 0 \%$ & $0 / 0 \%$ & -- & -- & -- & -- & -- & -- & $0 / 0 \%$ & -- \\
\hline${ }^{5} \operatorname{Radon}(\mathrm{pCi} / \mathrm{L})$ & -- & -- & $12 / 21.1 \%$ & -- & $0 / 0 \%$ & -- & -- & -- & -- & -- & -- \\
\hline Uranium $(\mu \mathrm{g} / \mathrm{L})$ & -- & $28 / 46.7 \%$ & $0 / 0 \%$ & -- & -- & -- & -- & -- & -- & -- & -- \\
\hline Methane (mg/kg) & -- & -- & -- & -- & -- & $2 / 3.3 \%$ & $1 / 1.7 \%$ & -- & -- & -- & -- \\
\hline Benzene (mg/kg) & -- & $37 / 61.7 \%$ & $0 / 0 \%$ & -- & -- & -- & -- & -- & -- & -- & -- \\
\hline
\end{tabular}

${ }^{1}$ For systems that use conventional or direct filtration, at no time can turbidity (cloudiness of water) go higher than 1 Nephelometric Turbidity Unit (NTU), and samples for turbidity must be less than or equal to 0.3 NTUs in at least 95 percent of the samples in any month. Systems that use filtration other than the conventional or direct filtration must follow State limits, which must include turbidity at no time exceeding 5 NTUs.

${ }^{2}$ There are no drinking water standards for hydrogen sulfide gas, but the odor threshold at which the human nose can smell hydrogen sulfide gas is $0.05 \mathrm{mg} / \mathrm{L}$.

${ }^{3}$ For public water systems no more than 5.0 percent samples total coliform-positive (TC-positive) in a month. (For water systems that collect fewer than 40 routine samples per month, no more than one sample can be total coliform-positive per month.) Every sample that has total coliform must be analyzed for either fecal coliforms or $E$. coli if two consecutive TC-positive samples, and one is also positive for $E$. coli fecal coliforms, system has an acute MCL violaton.

${ }^{4}$ Lead and copper are regulated by a Treatment Technique that requires systems to control the corrosiveness of their water. If more than 10 percent of tap water samples exceed the action level, water systems must take additional steps. For copper, the action level is 1,300 $\mu \mathrm{g} / \mathrm{L}$, and for lead is $15 \mu \mathrm{g} / \mathrm{L}$.

${ }^{5} \mathrm{In} 1999$ the EPA proposed an MCL of $300 \mathrm{pCi} / \mathrm{L}$ for radon in drinking water, and to date the rule has yet to be finalized. Therefore the MCL for radon is referenced as a proposed standard. An alternate MCL (AMCL) for radon was proposed for public water systems that initiated a radon mitigation program. Additional information on radon may be found at https://archive.epa.gov/water/archive/web/html/regulations.html. 


\section{Field Measurements of $\mathrm{pH}$, Alkalinity, Turbidity, Specific Conductance, and Dissolved Oxygen}

Most of the constituents analyzed did not exceed any of the standards (table $3 A$ ). There were several notable exceptions, most of which were not unexpected based on previous studies. Turbidity exceeded the 5-NTU TT drinking-water standard in 14 of 60 (23 percent) sites sampled and exceeded the 1-NTU TT standard in 51 of 60 ( 85 percent) sites sampled (table $3 B$ ). Turbidity is common in many wells in southern West Virginia and may be related to iron oxyhydroxide precipitates, sediment carried into the aquifers from the shallow soil zone due to improperly constructed or cased wells or transported to the aquifer in shallow stress-relief fracture zones. Many residents of southern West Virginia have filtration systems to remove turbidity from their source water. For this study, all samples were collected prior to any filtration or other treatments and were therefore indicative of total and dissolved constituents in the untreated water. The minimum, maximum, mean, and median turbidity levels for the 60 sites sampled were $0.5,270,15.2$ and 2.55 NTRUs, respectively (table 4).

The drinking-water standard for $\mathrm{pH}$, which is a measure of whether water is acidic, alkaline, or neutral, has an EPA SMCL in the range of 6.5-8.5, with $\mathrm{pH}$ values above 8.5 consistent with alkaline water, and $\mathrm{pH}$ values less than 6.5 consistent with acidic water, both of which can be corrosive to plumbing fixtures. Corrosive water can cause trace elements and other contaminants to leach from plumbing lines and plumbing fixtures, especially those of metallic composition such as copper or galvanized steel pipes. For the sites sampled,
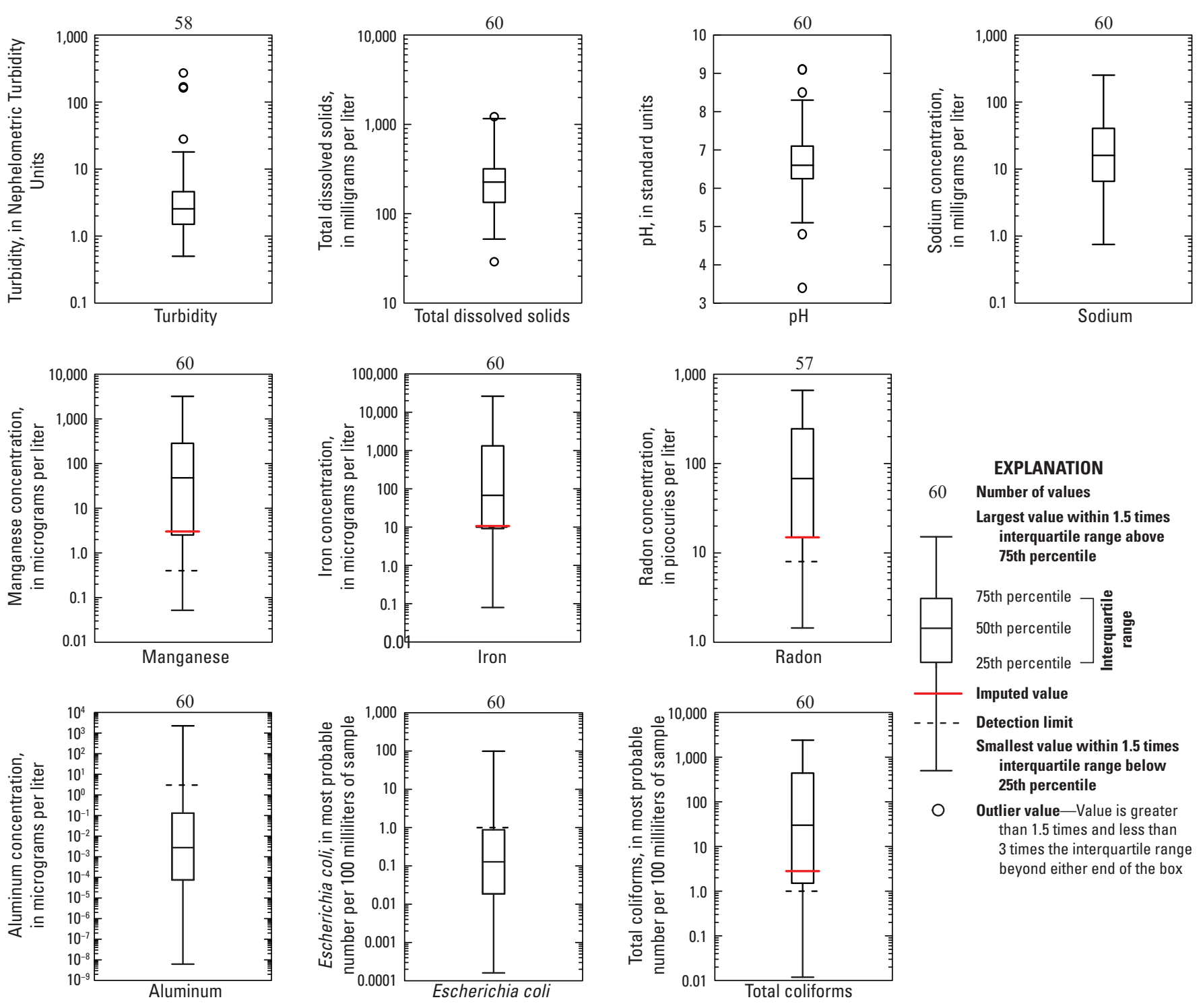

Figure 6. Distribution of concentrations of constituents that commonly exceed one or more of the drinking-water standards for 10 percent or more of the sites sampled. 
Table 4. Statistical summary of analytical data for selected constituents analyzed in water samples from the 60 sites sampled in the West Virginia southern coal-field province.

[ft, feet; NAVD88, North American Vertical Datum of 1988; bls, below land surface; in., inches; gal/min, gallons per minute; ${ }^{\circ} \mathrm{C}$, degrees Celsius; mg/L, milligrams per liter; std, standard; $\mu \mathrm{S} / \mathrm{cm}$, microsiemens per centimeter at 25 degrees Celsius; NTRU, nephelometric turbidity ratio units; <, less than; >, greater than; $\mathrm{N}$, nitrogen; $\mathrm{NO}_{3}+\mathrm{NO}_{2}$, nitrate plus nitrite; $\mathrm{P}$, phosphorus; MPN/100 mL, most probable number per 100 milliliters of sample; $\mu \mathrm{g} / \mathrm{L}$, micrograms per liter; $\mathrm{nc}$, all values less than method detection limits therefore mean and median concentrations were not computed; $\mathrm{pCi} / \mathrm{L}$, picocuries per liter; $\mathrm{mg} / \mathrm{kg}$, milligrams per kilogram; E, exponential value]

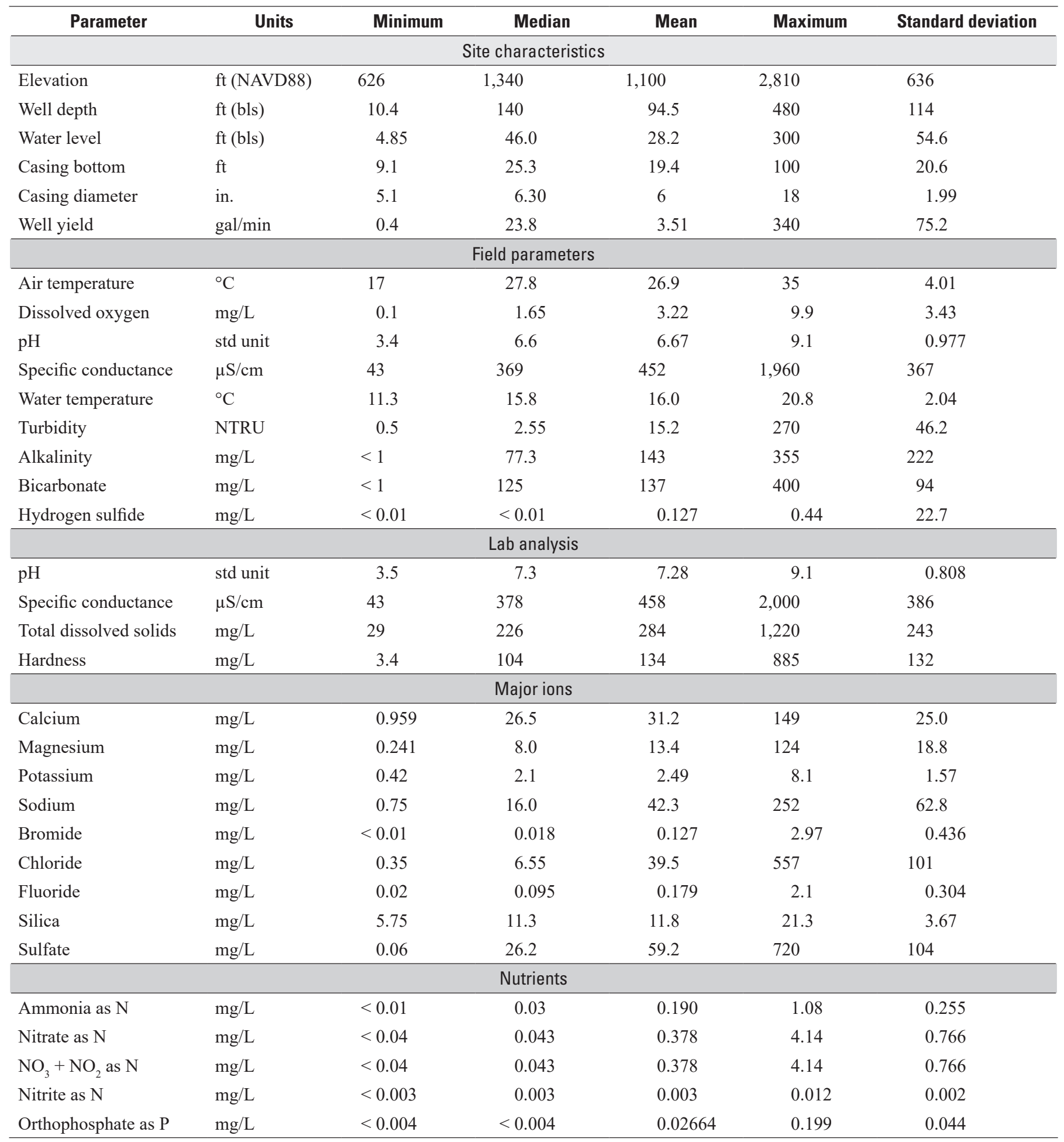


Table 4. Statistical summary of analytical data for selected constituents analyzed in water samples from the 60 sites sampled in the West Virginia southern coal-field province.-Continued

[ft, feet; NAVD88, North American Vertical Datum of 1988; bls, below land surface; in., inches; gal/min, gallons per minute; ${ }^{\circ} \mathrm{C}$, degrees Celsius; mg/L, milligrams per liter; std, standard; $\mu \mathrm{S} / \mathrm{cm}$, microsiemens per centimeter at 25 degrees Celsius; NTRU, nephelometric turbidity ratio units; $<$, less than; >, greater than; $\mathrm{N}$, nitrogen; $\mathrm{NO}_{3}+\mathrm{NO}_{2}$, nitrate plus nitrite; $\mathrm{P}$, phosphorus; MPN/100 mL, most probable number per 100 milliliters of sample; $\mu \mathrm{g} / \mathrm{L}$, micrograms per liter; $\mathrm{nc}$, all values less than method detection limits therefore mean and median concentrations were not computed; $\mathrm{pCi} / \mathrm{L}$, picocuries per liter; $\mathrm{mg} / \mathrm{kg}, \mathrm{milligrams}$ per kilogram; E, exponential value]

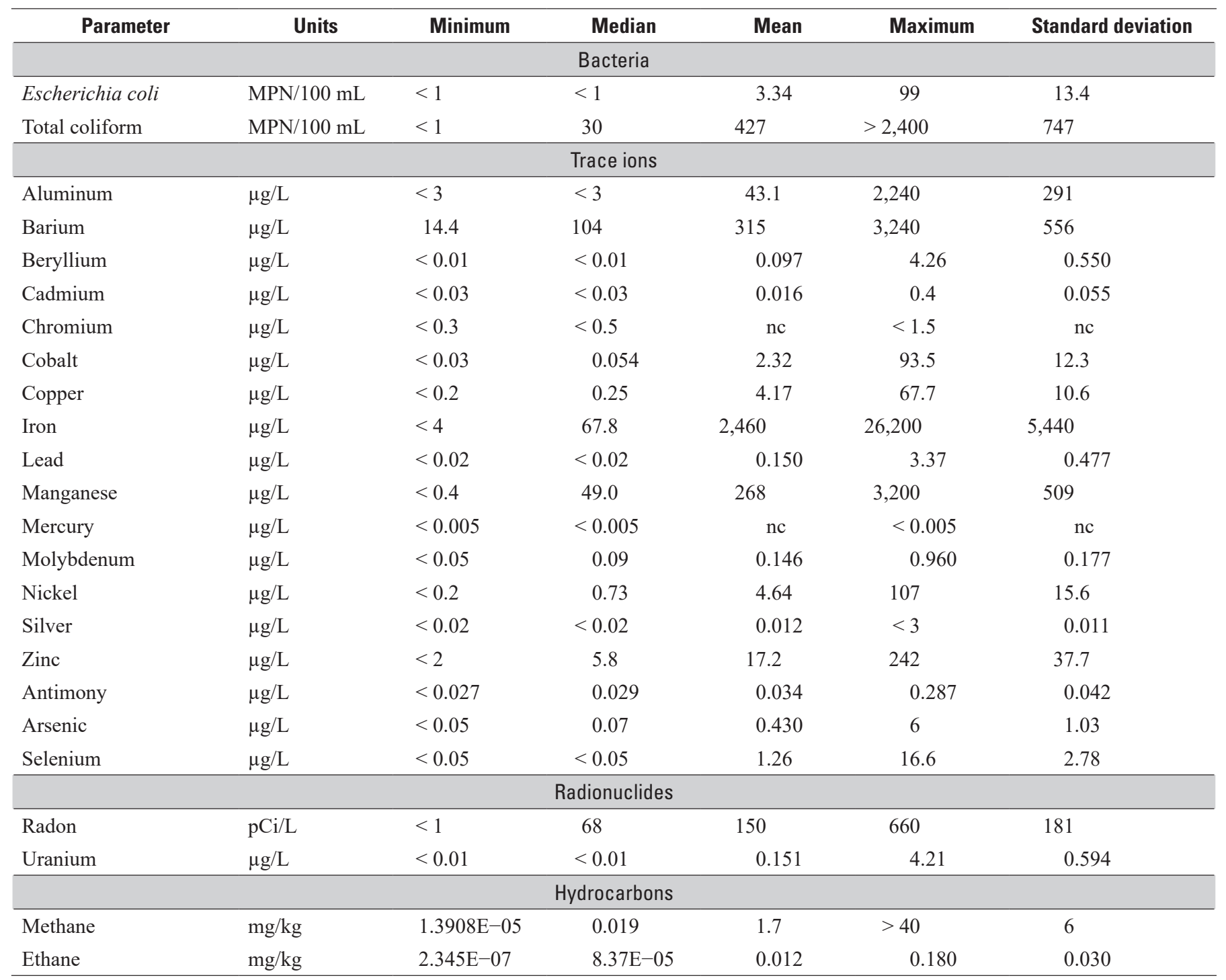


31 (51.7 percent) were outside the $\mathrm{pH}$ SMCL range. Of those 31 sites, 28 (90 percent) were indicative of acidic water and only 3 (10 percent) were indicative of alkaline water. The minimum, maximum, mean, and median field $\mathrm{pH}$ levels for the 60 sites sampled were 3.4, 9.1, 6.7 and 6.6 standard $\mathrm{pH}$ units, respectively (table 4).

\section{Corrosivity and Potential for Galvanic Corrosion}

Alkaline or acidic waters can leach iron, lead, copper, zinc, and other metallic components from galvanized or copper plumbing systems. A recent USGS study computed two indices of potential corrosivity, the Langelier Saturation Index (LSI) and the potential to promote galvanic corrosion (PPGC), for groundwater across the United States and indicated that West Virginia was among the states with a high potential for corrosive groundwater (Belitz and others, 2016).

The LSI is a measure of calcite saturation and can be used as an indicator of the potential for calcium scale to form in plumbing. The index is computed based on $\mathrm{pH}$, water temperature and concentrations of TDS, calcium, and alkalinity. The LSI was computed for all 60 sites sampled. LSI values less than -0.5 are classified as potentially corrosive, indeterminate if greater than or equal to -0.5 and less than or equal to 0.5 , and scale forming if greater than 0.5 . Of the 60 sites sampled, 49 sites ( 82 percent) had an LSI less than -0.5 indicative of corrosive waters, 10 sites had LSI values in the indeterminate range, and 1 site had an LSI value of alkaline scale-forming water.

The corrosivity of water alone is insufficient to assess whether water from a well has the PPGC, the potential to leach trace metals from galvanized pipes and boilers or from copper pipe soldered with lead tin solder. The PPGC can be estimated from the chloride sulfate molar ratio (CSMR). Nguyen and others (2011) developed a decision tree to help utilities evaluate treatment alternatives that might prevent galvanic corrosion of lead. Three levels of concern were defined based on the CSMR (with concentrations in milligrams per liter) and alkalinity (with concentrations in milligrams per liter as calcium carbonate $\left(\mathrm{CaCO}_{3}\right)$ : no concern, significant concern, and serious concern. Nguyen and others (2011) noted that if there is no lead present in the system, or if there are no partially replaced lead components, then the classification is "no concern." However, for this report, untreated groundwater was evaluated, and the three-tier classification system was applied without consideration of the presence or absence of lead in the raw source water, or within the water distribution system, to assess the PPGC for the sites sampled. The three PPGC levels, which are based on chloride-sulfate mass ratios and the alkalinity, are defined as low, moderate, and high: if CSMR is less than 0.2, then PPGC is low; if the CSMR is greater than 0.2 but less than 0.5, then PPGC is moderate; if CSMR is greater than 0.5 and alkalinity is greater than or equal to $50 \mathrm{mg} / \mathrm{L}$, then PPGC is moderate; and if CSMR is greater than 0.5 and alkalinity is less than $50 \mathrm{mg} / \mathrm{L}$, then PPGC is high.
Of the 60 sites sampled, only 1 (1.7 percent) had a PPGC that was classified as high, 32 (53.3 percent) were classified as moderate, and 27 (45.0 percent) were classified as low. Although the one sample with high potential for galvanic corrosion was classified as corrosive based on the LSI, most of the other samples classified as corrosive based on the LSIs were found to have moderate or low PPGC. Since the PPGC classification is partly based on total alkalinity, the moderate to high levels of alkalinity present in groundwater in the study area buffer the water and reduce the potential to promote galvanic corrosion in public and residential water systems in the study area.

\section{Indicator Bacteria}

Both total coliform bacteria and E. coli also were detected in groundwater samples (table $3 B$ ). Total coliforms, which are a broad class of indicator bacteria, are common in groundwater in southern West Virginia and were detected in 39 of the 60 sites ( 65 percent) sampled. The presence of total coliform bacteria is a potential indicator of surface contamination, due to improperly constructed or cased wells, or infiltration of soil or other surface contaminants through stress-relief fractures or other direct connections to groundwater aquifers such as those caused by subsidence due to underground coal mining, which may intersect a well bore. The presence of total coliform bacteria is not necessarily an indicator of potential pathogens in the water due to their common occurrence, however, they can indicate that the well may be subject to bacterial and viral pathogens. E. coli bacteria, however, are much more indicative of fecal contamination of groundwater from either human or animal sources. Although only 14 of the 60 (23 percent) sites sampled had detections of $E$. coli bacteria, the presence of $E$. coli in groundwater may be considered an indicator of other related pathogens such as viruses. In these cases, chlorination, ozonation, or ultraviolet light treatment may be appropriate to kill potential pathogenic microorganisms.

\section{Nutrients}

Nitrate and nitrite are common nutrients that can exceed drinking-water standards in agricultural areas of West Virginia, but the occurrence of nitrate and other nutrients at concentrations approaching drinking-water standards is uncommon for non-agricultural areas of the State (Chambers and others, 2012). As there is no commercial agricultural activity within the study area, and limited agricultural activity in residential gardens, elevated concentrations of nitrate, nitrite, and orthophosphate were not expected in groundwater samples collected in the study area. Nitrate is commonly derived from agricultural fertilizers, both synthetic and those from animal manure, but also can be derived from sewage treatment plant effluent or septic systems. Another less common potential source of nitrate, but one that may occur within the study area, 
is nitrate from the ammonium-nitrate-fuel oil (ANFO), which is a common explosive used in the surface mining industry.

As expected, nitrate and nitrite concentrations for the 60 sites sampled were low, and none of the sites sampled exceeded the 10 or $1 \mathrm{mg} / \mathrm{L}$ EPA MCL for either nitrate or nitrite, respectively. The maximum nitrate concentration was $4.14 \mathrm{mg} / \mathrm{L}$ and the minimum was $<0.04 \mathrm{mg} / \mathrm{L}$. Median nitrate, ammonia, and orthophosphate concentrations were all very low, with concentrations of $0.043,0.030$, and less than 0.004 (below method detection limit) $\mathrm{mg} / \mathrm{L}$, respectively. Nevertheless, concentrations of nitrate exceeding $1 \mathrm{mg} / \mathrm{L}$ were measured at seven sites, but there was no statistically significant correlation between nitrate and bacteria. Only three of the seven sites had nitrate concentrations greater than $1 \mathrm{mg} / \mathrm{L}$ and had no detectable $E$. coli bacteria; the mean $E$. coli concentration for those seven sites was less than 16 most probable number per 100 milliliters of sample (MPN/100 mL). Only one of the seven sites with nitrate concentrations greater than $1 \mathrm{mg} / \mathrm{L}$ had a non-detect of total coliform, but the mean total coliform concentration for those seven sites was $541 \mathrm{MPN} / 100 \mathrm{~mL}$, which was similar to the mean total coliform concentration for all 60 sites sampled (427 MPN/100 mL of sample). Therefore, it is difficult to determine the source of the nutrients, whether related to explosive residue, septic effluent, feces from wildlife, connection to streams with a high fecal waste load, atmospheric deposition, or a combination of these various sources. Ammonia, which is typically only present in reduced waters in significant concentrations, also was generally low for the sites sampled. Of the 60 sites sampled, 35 (58 percent) did not contain detectable concentrations of ammonia, and the median and maximum concentrations were low at 0.03 and $1.08 \mathrm{mg} / \mathrm{L}$, respectively (table 4 ). None of the 60 sites sampled exceeded the EPA 30-mg/L HBV for ammonia (table 4).

\section{Hardness and Major lons}

TDS, which is a measure of the amount of dissolved constituents in the water sample and is commonly related to water hardness, exceeded the $500-\mathrm{mg} / \mathrm{L}$ EPA SMCL in 6 of 60 (10 percent) sites sampled (table $3 B$ ). Water with hardness less than $60 \mathrm{mg} / \mathrm{L}$ is considered soft water, and only 13 of the 60 sites sampled (21.7 percent) had soft water. Water with a hardness greater than $60 \mathrm{mg} / \mathrm{L}$ but less than or equal to $120 \mathrm{mg} / \mathrm{L}$ is considered moderately hard water, and the majority ( 23 of 60 ) of sites sampled (38.3 percent) had moderately hard water. Hard water, with hardness greater than $120 \mathrm{mg} / \mathrm{L}$ and less than or equal to $180 \mathrm{mg} / \mathrm{L}$ was found in 13 of the 60 sites $(21.7$ percent) sampled, and only 11 of the 60 sites sampled (18.3 percent) had hardness greater than $180 \mathrm{mg} / \mathrm{L}$, which is considered very hard water. Overall, 40 percent of the sites sampled had hardness representative of hard to very hard water, but most of the sites sampled had water that was considered moderately hard to soft. Soft water can make it difficult for soap to work effectively, and water that is too hard can contribute to scale deposits in water heaters and plumbing lines.
Most of the water hardness is typically caused by calcium and magnesium. Carbonate hardness is derived primarily from the dissolution of carbonate minerals, such as calcite (calcium carbonate) or dolomite (calcium magnesium carbonate), which are common components of limestone and calcareous shales; however, other non-carbonate mineral dissolution such as gypsum (calcium sulfate) and calcium or magnesium chloride salts can contribute to non-carbonate hardness. For the 60 sites sampled, both total hardness and non-carbonate hardness were measured. Of the 60 sites sampled, 17 (28.3 percent) had noncarbonate hardness that exceeded 50 percent of total hardness, which indicates that carbonate dissolution dominates more than dissolution of non-carbonate minerals in much of the study area. Of these 17 sites, 10 (58.8 percent) were in the Kanawha Formation in the western part of the study area, 4 (23.5 percent) were in the New River Formation, and only 3 (17.6 percent) were in the older Pocahontas Formation in the eastern part of the study area. A recent study conducted in the Elkhorn area of McDowell County, West Virginia, in which thin-section analysis of bedrock samples was performed indicated that a substantial proportion of siderite grains, an iron carbonate mineral, are present in sandstone bedrock within the study area. Massive sequences of sandstone are typical of the Pocahontas and New River Formations in the eastern part of the study area, but the bedrock grades to a larger percentage of shale bedrock in the younger Kanawha and Allegheny Formations in the western part of the study area. The 18 sites sampled with a larger proportion of non-carbonate hardness included 7 mine outfalls and 11 wells; 6 of the 7 mine outfalls derived water from the Kanawha Formation. Mine outfall discharges frequently have a different geochemical signature than well samples, typically reflecting oxidation processes as opposed to reduction processes, which dominate in deeper wells, as discussed further in the Geochemistry section of this report. Calcium, magnesium, sodium, potassium, sulfate, chloride, silica, and bicarbonate are the major ions that contribute to the TDS content and hardness of water within the study area, and the median concentrations of these constituents for the 60 sites sampled were 26.5, 8.0, $16.0,2.1,26.2,6.55,11.3$, and $125 \mathrm{mg} / \mathrm{L}$, respectively (table 4).

Sodium, chloride, fluoride, and sulfate are common constituents in groundwater within the study area. Sulfate and chloride in water can impart a salty taste to water at concentrations greater than $250 \mathrm{mg} / \mathrm{L}$. Sulfate and chloride concentrations in the study area were generally low, and only 2 of 60 (3.3 percent) sites sampled contained either sulfate or chloride concentrations exceeding the EPA SMCL of $250 \mathrm{mg} / \mathrm{L}$ (table 3). Sodium has an EPA HBV of $20 \mathrm{mg} / \mathrm{L}$ for individuals who are on a sodium-restricted diet for blood pressure or other health reasons (table $3 A$ ). Sodium concentrations were elevated in a large proportion of the sites sampled, with 27 of 60 (45 percent) exceeding the 20-mg/L HBV (table $3 B$ ). Fluoride in high concentrations can cause mottling or discoloration of teeth. The EPA SMCL for fluoride is $2.0 \mathrm{mg} / \mathrm{L}$ and only 1 of 60 (1.7 percent) sites sampled contained fluoride greater than this concentration (table $3 B$ ). 


\section{Metals and Trace Elements}

Manganese and iron were the second and third most prevalent contaminants detected in the groundwater samples collected for this study, with 30 of 60 (50 percent) sites analyzed for manganese and 25 of 60 (42 percent) sites analyzed for iron exceeding the proposed 50- and 300- $\mu \mathrm{g} / \mathrm{L}$ SMCL drinking-water standards, respectively, for aesthetic criteria such as taste, odor, or staining of plumbing fixtures (table $3 A$ ). Fourteen of the 60 sites sampled ( 23 percent) had concentrations of manganese that exceeded the 300- $\mu \mathrm{g} / \mathrm{L}$ USGS HBSL, and 1 site exceeded the 1,600- $\mu \mathrm{g} / \mathrm{L}$ EPA DWEL, which is based on a lifetime exposure level. There are no applicable HBSLs or DWELs for iron in drinking water. The median, maximum, and minimum concentrations of iron for the 60 sites sampled were $67.8,26,200$, and less than $4 \mu \mathrm{g} / \mathrm{L}$, respectively, and the median, maximum, and minimum concentrations of manganese for the 60 sites sampled were 49.0, 3,200, and less than $0.4 \mu \mathrm{g} / \mathrm{L}$, respectively (table 4 ).

Some trace metals can present health risks or cause aesthetic problems if present in drinking water at elevated concentrations (table $3 A$ ). The EPA TT and MCL for barium and beryllium of 2,000 and $4 \mu \mathrm{g} / \mathrm{L}$, respectively, were exceeded at 2 (3.3 percent) and 1 ( 1.7 percent) of the 60 sites sampled, respectively. The EPA TT drinking-water standards for lead and arsenic are 15 and $10 \mu \mathrm{g} / \mathrm{L}$, respectively, and none of the 60 sites sampled had lead or arsenic concentrations in excess of these standards. The EPA MCLG drinking-water standards for lead and arsenic are both $0 \mu \mathrm{g} / \mathrm{L}$, and 25 (41.7 percent) and 32 (53.3 percent) of the 60 sites sampled had detectable concentrations of lead and arsenic. The maximum lead and arsenic concentrations detected in the 60 sites sampled were 3.37 and $6.0 \mu \mathrm{g} / \mathrm{L}$, respectively. Even though the source water contains lead, arsenic, and other trace metals at low or non-detectable concentrations, waters that are corrosive may leach these contaminants from galvanized pipe and leadbased solder commonly used in indoor plumbing prior to the implementation of PVC, chlorinated polyvinyl chloride, and other plastic plumbing lines. Aluminum does not have an EPA MCL, but the SMCL for aluminum is $0.05-2.0 \mu \mathrm{g} / \mathrm{L}$, and 8 of 60 sites sampled had aluminum concentrations more than the EPA SMCL (table 3). The EPA MCL for mercury is $2 \mu \mathrm{g} / \mathrm{L}$, but mercury was detected in only 1 of the 60 sites sampled at a concentration of $0.005 \mu \mathrm{g} / \mathrm{L}$, equivalent to the method detection limit for the analyte. None of the 60 sites sampled had antimony, cadmium, chromium, copper, or selenium concentrations exceeding the EPA MCLs of 6, 5, $100,1,300$ and $50 \mu \mathrm{g} / \mathrm{L}$, respectively, molybdenum concentrations exceeding the $40-\mu \mathrm{g} / \mathrm{L}$ USGS HBSL, or copper, silver, and zinc concentrations exceeding the EPA SMCLs of 1,000, 100 , or $5,000 \mu \mathrm{g} / \mathrm{L}$, respectively. One of the 60 sites $(1.7$ percent) sampled had a concentration of nickel that exceeded the $100-\mu \mathrm{g} / \mathrm{L}$ USGS HBSL. Median concentrations of barium, beryllium, lead, arsenic, aluminum, mercury, antimony, cadmium, chromium, copper, and selenium were also typically low, with median concentrations for the 60 sites sampled of 104 , less than 0.01 , less than $0.02,0.07$, less than 3.0 , less than $0.005,0.029$, less than 0.03 , less than $0.5,0.25$, and less than $0.05 \mu \mathrm{g} / \mathrm{L}$, respectively. Except for barium, median concentrations were typically at or below the method detection limits.

\section{Dissolved Combustible Gases}

Methane and hydrogen sulfide gas are both potentially explosive gases that are common in coal mines, so the potential for these gases to be present in groundwater in the study area was a concern. There are no EPA drinking-water standards for either hydrogen sulfide or methane gas. Inhalation of hydrogen sulfide gas can cause headaches and dizziness at a concentration of 20 parts per million (ppm), eye problems (50-100 ppm), pulmonary edema (200-300 ppm), and in extremely high concentrations, can even result in unconsciousness (700-1,000 ppm) or nearly instantaneous death (1,000-2,000 ppm). The U.S. Department of Labor, Occupational Safety and Health Administration immediately dangerous to life and health (IDLH) threshold (U.S. Department of Labor, 2018) is 1,000 ppm (accessed February 12, 2018, at https://www.osha.gov/SLTC/hydrogensulfide/hazards. html). Fortunately, the odor threshold for hydrogen sulfide gas is extremely low at $0.05 \mathrm{mg} / \mathrm{L}$, and hydrogen sulfide has a distinctive intense rotten egg smell that is extremely unpleasant and is easily detected by the human nose. Accumulation of hydrogen sulfide gas in enclosed spaces can also pose an explosion hazard as hydrogen sulfide is extremely combustible. Hydrogen sulfide gas was only detected at 11 of the 60 (18.3 percent) sites sampled at very low concentrations. The maximum concentration detected was only $0.44 \mathrm{mg} / \mathrm{L}$ (ppm), and only 5 of the 59 sites ( 8.5 percent) sampled had concentrations at or above the $0.05 \mathrm{mg} / \mathrm{L}$ odor threshold.

The Office of Surface Mining Reclamation and Enforcement (OSMRE) published LOC for methane in groundwater is $10 \mathrm{mg} / \mathrm{L}$, and the IAL at which mitigation of the gas issue is recommended is $28 \mathrm{mg} / \mathrm{L}$ (Eltschlager and others 2001). Only 2 of 59 (3.4 percent) sites sampled for methane gas exceeded the $10-\mathrm{mg} / \mathrm{L}$ OSMRE LOC and only 1 of the 59 (1.7 percent) sites sampled exceeded the 28-mg/L IAL. Median, minimum, and maximum concentrations of methane gas for the 59 sites sampled were 0.019 , less than 0.000014 , and greater than $40 \mathrm{mg} / \mathrm{kg}$, respectively (table 4).

\section{Radioactive Constituents}

Radon and uranium are two radioactive elements that are commonly present in bedrock in the study area. A statewide assessment of groundwater quality in West Virginia 
(Chambers and others, 2012) indicated that although radon concentrations do not commonly exceed the EPA proposed AMCL or MCL for radon in drinking water, isolated sites primarily in the western part of the study have the potential to have radon gas concentrations in drinking water more than the proposed MCL. For the 60 sites sampled, 12 (21.1 percent) met or exceeded the EPA proposed MCL for radon, but none exceeded the 4,000 picocuries per liter ( $\mathrm{pCi} / \mathrm{L}$ ) AMCL, which is applicable to public drinking-water systems that have adopted radon mitigation programs. Sites with radon gas concentrations exceeding the $300-\mathrm{pCi} / \mathrm{L}$ proposed MCL have the potential for airborne concentrations of radon to exceed the 4-pCi/L indoor air standard. Inhalation of radon can cause lung cancer, and the 4-pCi/L indoor air standard is based on an inhalation standard. Therefore, homeowners whose wells have dissolved radon gas concentrations exceeding $300 \mathrm{pCi} / \mathrm{L}$ may be advised to test their indoor air concentrations. The mean radon concentration was $150 \mathrm{pCi} / \mathrm{L}$, the median was only $68 \mathrm{pCi} / \mathrm{L}$; and the maximum radon concentration was $660 \mathrm{pCi} / \mathrm{L}$ (table 4 ).

None of the sites sampled had uranium concentrations in excess of the 30- $\mu \mathrm{g} / \mathrm{L}$ EPA MCL drinking-water standard. Since uranium is a radioactive element, the EPA MCLG is $0 \mu \mathrm{g} / \mathrm{L}$, and 28 of the 60 sites sampled (46.7 percent) had detectable concentrations of uranium. The maximum uranium concentration for sites sampled was $4.21 \mu \mathrm{g} / \mathrm{L}$, the mean concentration was $0.151 \mu \mathrm{g} / \mathrm{L}$, but the median concentration was less than $0.01 \mu \mathrm{g} / \mathrm{L}$, which is lower than the method detection limit (table 4).

\section{Groundwater Quality in Relation to Geologic Formation and Type of Mining}

Both the geologic formation and the type of mining in an area can substantially affect the chemistry of the waters derived from specific wells or mine outfalls. The proportion of shale compared to sandstone bedrock may be a factor affecting groundwater quality in the study area. The highest proportions of shale bedrock are in the Kanawha and the Pocahontas Formations.

There also are differences in the depositional sequence for the various formations. The older rocks in the southern coal-field province were deposited in an area that received more paleo-rainfall and paleo-recharge and thus, the sulfur content was diluted compared to the younger rocks in the northern coal-field province, which formed in a drier paleoclimate with higher ash, nutrient, and dissolved solids content that collectively resulted in higher sulfur content (Cecil and others, 1985). The younger rocks were deposited in marine environments that had higher contents of sulfur and calcium carbonate. In contrast, the older rocks formed in areas that were marginally brackish, and therefore had a lower content of sulfur and calcium carbonate.
Whereas the lithologic composition of coal seams and overburden strata can affect groundwater quality, an additional factor that can affect groundwater quality may be the type of mining in the area near the well or mine outfall. There is a distinct difference in the type of mining between the eastern and western parts of the study area, as underground mining dominates in the eastern part, and there is a substantially larger percentage of surface mining in the western part (fig. 5). Surface mining, especially mountain top removal, disturbs a much larger percentage of overburden strata than contour surface mining methods. Mountain top coal mining is more prevalent in the western part of the study area than in the eastern part of the study area.

Both parts of the study area also may be differentiated by geologic formation (fig. 2), with the western part made up of underground and surface coal mining in the Kanawha (33 sites) and Allegheny Formations (1 site), and the eastern part made up of underground and surface coal mining in the Pocahontas (9 sites), New River (16 sites), and the Bluestone and Princeton Formations (1 site). The proportion of surface mining (fig. 5) in the western part of the study area occupies $475.0 \mathrm{mi}^{2}$ or 81.5 percent of the total surface mined area of the study area, whereas the eastern part of the study area contains $107.6 \mathrm{mi}^{2}$ or 18.5 percent of the total surface mined area.

Wilcoxon signed-rank tests (Helsel, 2012) were run to determine whether there are statistically significant differences in the (1) various geologic formations, (2) type of site (well compared to outfall), (3) topographic setting (uplands or valleys), and (4) predominant type of mining (northwestern surface-mine-dominated region and southeastern undergroundmine-dominated region of the study area). Results of the Wilcoxon signed-rank tests for statistical significance are presented in table 5. For the various populations, statistical difference is indicated for populations with p-values less than 0.05 in the table, and only those constituents found to be statistically different for one or more populations are presented.

The distribution of chemical constituents with respect to geologic formation was examined by creating boxplots of the data for the various chemical constituents of concern for each major geologic formation within the study area. Boxplots were prepared for the major constituents that either (1) meet or exceed one or more of the drinking-water standards discussed previously, (2) significantly contribute to the water chemistry of the 60 sites sampled, or (3) relate to major geochemical processes that occur within the fractured bedrock and coal mine aquifers of southern West Virginia coal fields. These boxplots, the summary statistics presented in table 4 , and results of the Wilcoxon signed-rank tests (table 5) of statistical significance were used to assess groundwater quality with respect to geologic controls. For this study, based on the geographic distribution of sites required to cover the large study area, there was an unequal distribution of sites sampled in the various geologic formations within the study area. For the study, 60 sites were sampled, with 33 of the 60 sites in the Kanawha 
Table 5. Comparison of $p$-values from Wilcoxon signed ranked tests of statistical significance for site types, topographic settings, dominant types of mining, and geologic formations in the West Virginia southern coal-field province.

[ $p$-values less than 0.05 indicate statistical difference between compared populations; E, exponential value; nsd, no statistically significant difference; $\mathrm{N}$, nitrogen]

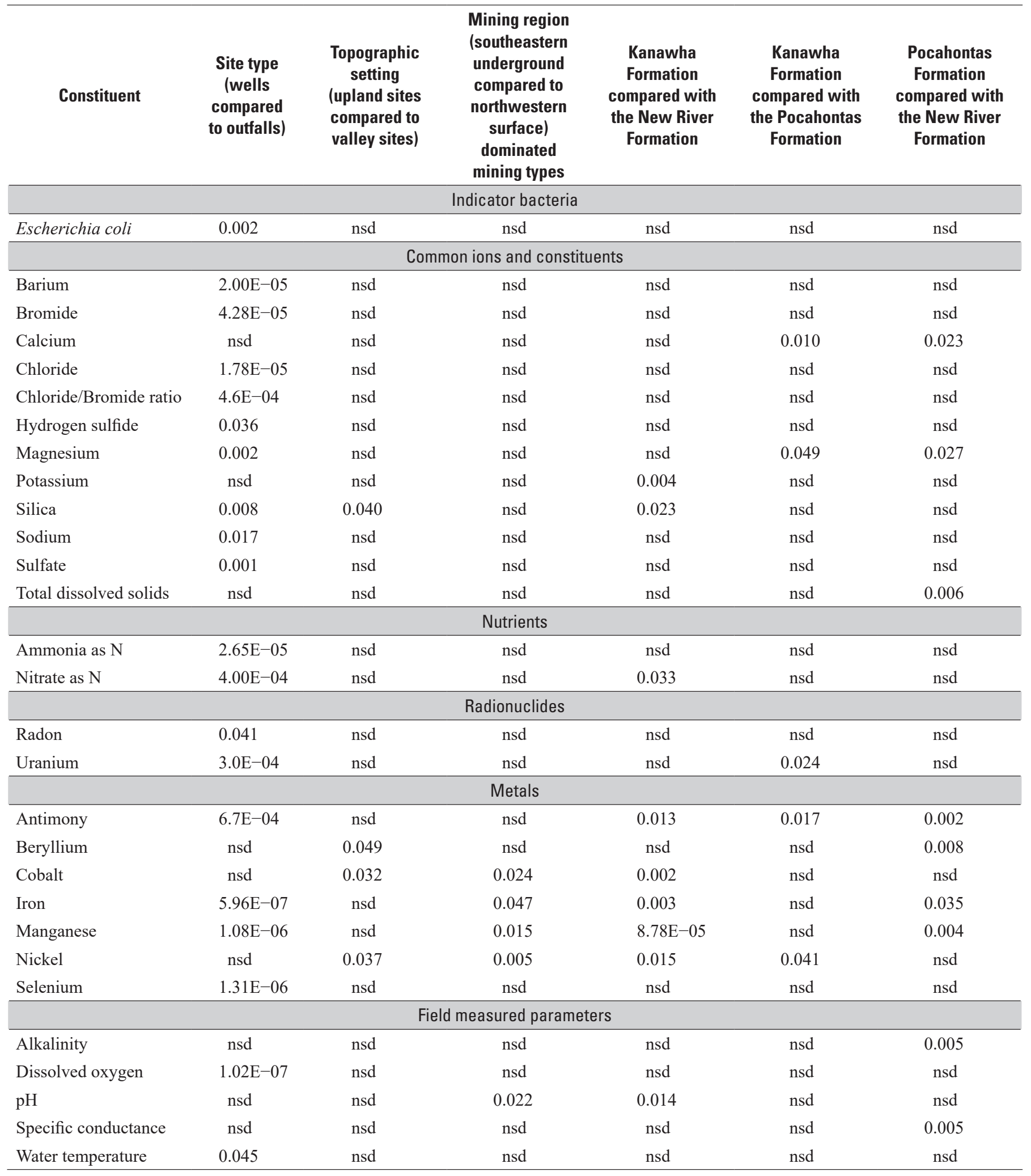


Formation, 16 sites in the New River Formation, 9 sites in the Pocahontas Formation, and 1 site each in the Bluestone and Princeton, and Allegheny Formations. Because one site within the Bluestone and Princeton Formations and one site within the Allegheny Formation were in close proximity to the Pocahontas and Kanawha Formations, and because they share common rock types with the adjacent geologic formations, the site within the Bluestone and Princeton Formations was included in the Pocahontas Formation, and the site within the Allegheny Formation was included in the Kanawha Formation for graphical examination and statistical analysis.

Generally, except for iron and manganese, there were few statistically significant differences in groundwater quality between the western surface-mine-dominated and eastern underground-mine-dominated areas (table 5; tables $6 A$ and $6 B$ ) for most constituents analyzed. Due to their typically low concentrations and numerous non-detect values, the p-values for constituents such as antimony, beryllium, cobalt, and nickel, even though statistically significant for certain population comparisons, likely do not merit discussion with respect to overall geochemical processes. Iron and manganese in groundwater are significantly higher in the eastern undergroundmine-dominated region than in the western surface-mine-dominated region. Whether this difference is related to the type of mining or geologic formation is unclear, but geology likely is the controlling factor.

Geologic controls are apparent when comparing chemical constituent concentrations for the various geologic formations, as there are a larger number of statistically significant differences among individual chemical constituents with respect to geologic formations (table 5 and tables $7 A, B$, and $C$ ) than for mining region and associated dominance of mining type. This is especially true when chemical constituent concentrations for the Kanawha and New River Formations are compared, with significant differences between the two formations indicated for potassium, silica, nitrate, antimony, cobalt, iron, manganese, and nickel. Iron and manganese concentrations were significantly higher in the New River Formation, whereas potassium and nitrate were significantly higher in the Kanawha Formation.

Comparison of chemical constituent concentrations in groundwater from the Kanawha and Pocahontas Formations indicates statistically significant differences for calcium, magnesium, uranium, antimony, and nickel, which are all higher in concentrations in the Pocahontas Formation than in the Kanawha Formation. Higher calcium and magnesium concentrations in the Pocahontas Formation are related to the buffering capacity of rocks within the formation, which combined with the low sulfur content of the Pocahontas Formation coal seams, especially the Pocahontas No. 3 coal seam, produces water with higher $\mathrm{pH}$ values for the Pocahontas Formation when compared to the New River Formation (tables $7 A$ and $7 B$ ).

Comparison of chemical constituent concentrations in groundwater from the Pocahontas and New River Formations indicates statistically significant differences for calcium, magnesium, TDS, antimony, beryllium, iron, manganese, alkalinity, and specific conductance. Constituent concentrations in groundwater from the Pocahontas Formation were significantly higher with respect to calcium, magnesium, TDS, antimony, alkalinity, and specific conductance than in groundwater from the New River Formation, but concentrations of iron, manganese, and beryllium were higher in groundwater from the New River Formation.

Trilinear diagrams, or "Piper plots" as they are commonly referred to, plot major chemical constituents and allow a quick visualization of the major ion chemistry of groundwater (fig. 7). The trilinear diagram that includes plots of the overall chemical composition of the 60 sites sampled with respect to geologic formation (fig. 7A) indicates that sites located within the Kanawha, Allegheny, and Pocahontas Formations can have a significant sodium and potassium content, whereas sites located in the New River Formation are predominantly a calcium and magnesium water type.

The trilinear diagram that compares sites in the western surface-mine-dominated and eastern underground-mine-dominated areas (fig. $7 B$ ) looks almost identical to the trilinear diagram that compares overall water chemistry by geologic formation (fig. $7 A$ ). This similarity is not surprising as a previous study of groundwater quality for reclaimed surface mines in West Virginia and Pennsylvania showed that beyond about 1,000 $\mathrm{ft}$ from reclaimed surface mines, the quality of groundwater downgradient is typically more consistent with the overall background water chemistry in unmined areas than that of water chemistry within $500 \mathrm{ft}$ of reclaimed surface mines (McAuley and Kozar, 2006). Most sites sampled for this study, in areas of active or past coal mining activity, were more than 1,000 ft from surface-mine areas, and although several wells were completed in underground abandoned coal mines, the majority were not. Since the sites sampled were farther than 1,000 ft from active or reclaimed surface mines, it is not likely that the water-quality signature of surface mining would be evident in the data collected for this study.

When data are plotted on a trilinear diagram with respect to $\mathrm{pH}$ and assigned to categories based on acidity or alkalinity (fig. $7 \mathrm{C}$ ), the alkaline and very alkaline waters are typically the same sites in the Pocahontas, Kanawha, and Allegheny Formations that had higher proportions of calcium and magnesium. Acidic waters are mostly within the Kanawha and New River Formations (eight and seven sites, respectively) and only three are within the Pocahontas Formation. 
Table 6A. Statistical summary of analytical results for groundwater samples for 34 sites from the West Virginia southern coalfield province, differentiated by the predominance of the type of mining, for the western surface-mined-dominated part of the study area.

[ft, feet; NAVD88, North American Vertical Datum of 1988; bls, below land surface; in., inches; gal/min, gallons per minute; ${ }^{\circ} \mathrm{C}$, degrees Celsius; mg/L, milligrams per liter; std, standard; $\mu \mathrm{S} / \mathrm{cm}$, microsiemens per centimeter at $25^{\circ} \mathrm{C} ; \mathrm{NTRU}$, nephelometric turbidity ratio units; <, less than; $\mathrm{N}$, nitrogen; $\mathrm{NO}_{3}+\mathrm{NO}_{2}$, nitrate plus nitrite; P, phosphorus; MPN/100 mL, most probable number per 100 milliliters of sample; >, greater than; $\mu \mathrm{g} / \mathrm{L}$, micrograms per liter; nc, all values less than method detection limits therefore mean and median concentrations were not computed; $\mathrm{pCi} / \mathrm{L}$, picocuries per liter; $\mathrm{mg} / \mathrm{kg}$, milligrams per kilogram; E, exponential value]

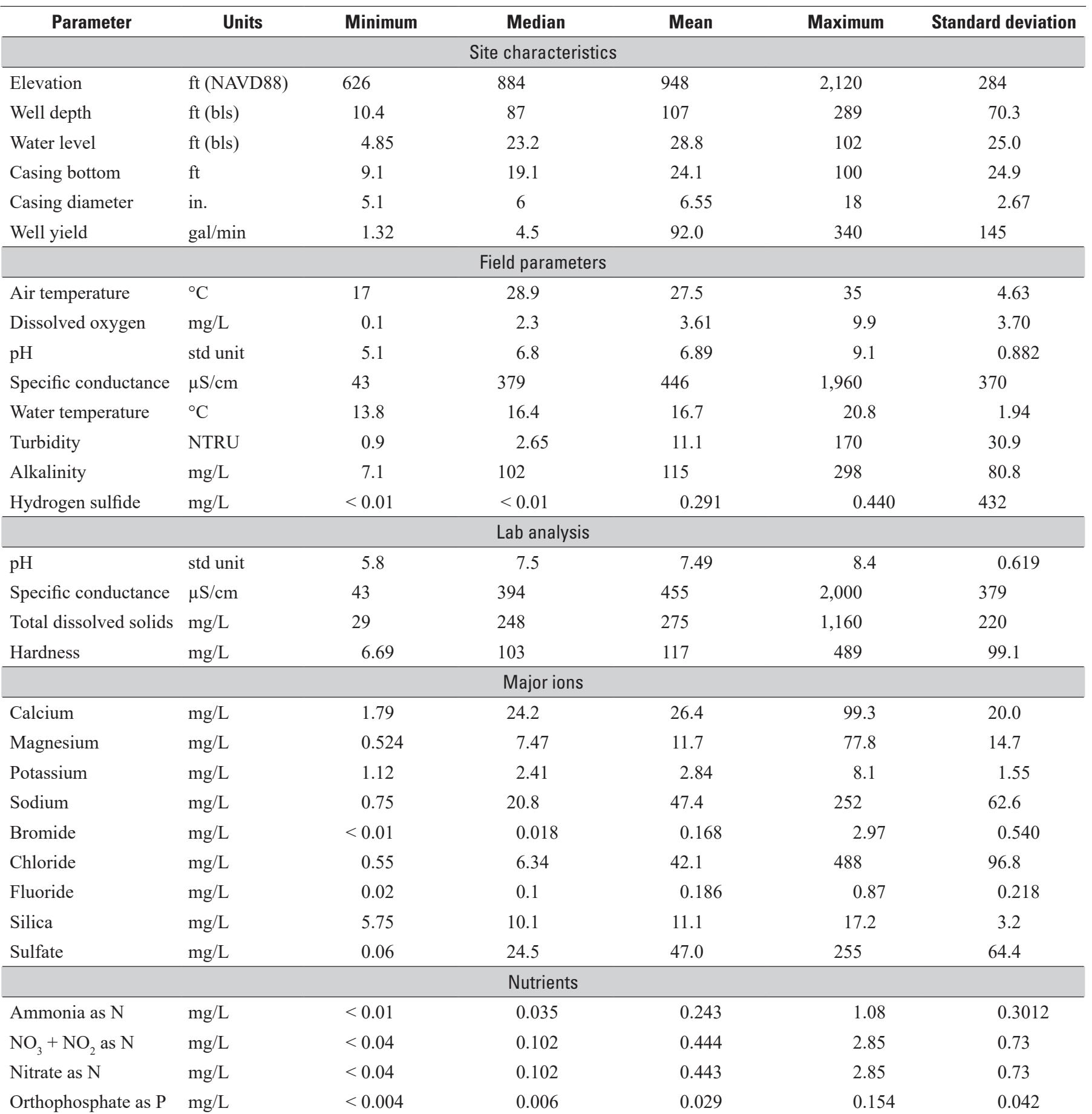


Table 6A. Statistical summary of analytical results for groundwater samples for 34 sites from the West Virginia southern coalfield province, differentiated by the predominance of the type of mining, for the western surface-mined-dominated part of the study area.-Continued

[ft, feet; NAVD88, North American Vertical Datum of 1988; bls, below land surface; in., inches; gal/min, gallons per minute; ${ }^{\circ} \mathrm{C}$, degrees Celsius; mg/L, milligrams per liter; std, standard; $\mu \mathrm{S} / \mathrm{cm}$, microsiemens per centimeter at $25^{\circ} \mathrm{C} ; \mathrm{NTRU}$, nephelometric turbidity ratio units; $<$, less than; $\mathrm{N}$, nitrogen; $\mathrm{NO}_{3}+\mathrm{NO}{ }_{2}$, nitrate plus nitrite; P, phosphorus; MPN/100 mL, most probable number per 100 milliliters of sample; >, greater than; $\mu \mathrm{g} / \mathrm{L}$, micrograms per liter; nc, all values less than method detection limits therefore mean and median concentrations were not computed; $\mathrm{pCi} / \mathrm{L}$, picocuries per liter; $\mathrm{mg} / \mathrm{kg}$, milligrams per kilogram; E, exponential value]

\begin{tabular}{|c|c|c|c|c|c|c|}
\hline Parameter & Units & Minimum & Median & Mean & Maximum & Standard deviation \\
\hline \multicolumn{7}{|c|}{ Bacteria } \\
\hline Escherichia coli & MPN/100 mL & $<1$ & $<1$ & 2.53 & 30 & 5.9 \\
\hline \multicolumn{7}{|c|}{ Trace ions } \\
\hline Aluminum & $\mu \mathrm{g} / \mathrm{L}$ & $<3$ & $<3$ & 2.22 & 32.2 & 5.97 \\
\hline Beryllium & $\mu \mathrm{g} / \mathrm{L}$ & $<0.01$ & $<0.01$ & 0.019 & 0.196 & 0.039 \\
\hline Cadmium & $\mu \mathrm{g} / \mathrm{L}$ & $<0.03$ & $<0.03$ & 0.010 & 0.09 & 0.011 \\
\hline Chromium & $\mu \mathrm{g} / \mathrm{L}$ & $<0.3$ & $<0.5$ & nc & $<1.5$ & $\mathrm{nc}$ \\
\hline Cobalt & $\mu \mathrm{g} / \mathrm{L}$ & $<0.03$ & 0.038 & 0.127 & 1.57 & 0.303 \\
\hline Copper & $\mu \mathrm{g} / \mathrm{L}$ & $<0.2$ & 0.25 & 4.56 & 67.7 & 12.8 \\
\hline Mercury & $\mu \mathrm{g} / \mathrm{L}$ & $<0.005$ & $<0.005$ & $\mathrm{nc}$ & $<0.005$ & $\mathrm{nc}$ \\
\hline Molybdenum & $\mu \mathrm{g} / \mathrm{L}$ & $<0.05$ & 0.081 & 0.144 & 0.819 & 0.178 \\
\hline Nickel & $\mu \mathrm{g} / \mathrm{L}$ & $<0.2$ & 0.36 & 1.12 & 6.1 & 1.65 \\
\hline Silver & $\mu \mathrm{g} / \mathrm{L}$ & $<0.02$ & $<0.02$ & nc & $<3$ & $\mathrm{nc}$ \\
\hline Zinc & $\mu \mathrm{g} / \mathrm{L}$ & $<2$ & 4.1 & 10.5 & 100 & 19.1 \\
\hline Antimony & $\mu \mathrm{g} / \mathrm{L}$ & $<0.027$ & $<0.027$ & 0.031 & 0.111 & 0.025 \\
\hline Arsenic & $\mu \mathrm{g} / \mathrm{L}$ & $<0.05$ & $<0.05$ & 0.329 & 6 & 1.07 \\
\hline Selenium & $\mu \mathrm{g} / \mathrm{L}$ & $<0.05$ & 0.065 & 1.24 & 9.3 & 2.331 \\
\hline
\end{tabular}


Table 6B. Statistical summary of analytical results for groundwater samples for 26 sites from the West Virginia southern coalfield province, differentiated by the predominance of the type of mining, for the eastern underground-mined-dominated part of the study area.

[ft, feet; NAVD88, North American Vertical Datum of 1988; bls, below land surface; in., inches; gal/min, gallons per minute; ${ }^{\circ} \mathrm{C}$, degrees Celsius; mg $/ \mathrm{L}$, milligrams per liter; std, standard; $\mu \mathrm{S} / \mathrm{cm}$, microsiemens per centimeter at $25^{\circ} \mathrm{C} ; \mathrm{NTRU}$, nephelometric turbidity ratio units; <, less than; $\mathrm{N}$, nitrogen; $\mathrm{NO}_{3}+\mathrm{NO}_{2}$, nitrate plus nitrite; P, phosphorus; MPN/100 mL, most probable number per 100 milliliters of sample; >, greater than; $\mu \mathrm{g} / \mathrm{L}$, micrograms per liter; nc, all values less than method detection limits therefore mean and median concentrations were not computed; $\mathrm{pCi} / \mathrm{L}$, picocuries per liter; $\mathrm{mg} / \mathrm{kg}$, milligrams per kilogram; E, exponential value]

\begin{tabular}{|c|c|c|c|c|c|c|}
\hline Parameter & Units & Minimum & Median & Mean & Maximum & Standard deviation \\
\hline \multicolumn{7}{|c|}{ Site characteristics } \\
\hline Elevation & ft (NAVD88) & 968 & 1,760 & 1,860 & 2,810 & 599 \\
\hline Water level & $\mathrm{ft}$ (bls) & 6 & 42.1 & 67.8 & 300 & 72.5 \\
\hline Casing bottom & $\mathrm{ft}$ & 13 & 20.3 & 26.8 & 63 & 15.1 \\
\hline Well yield & $\mathrm{gal} / \mathrm{min}$ & 0.4 & 3.2 & 3.3 & 7 & 1.79 \\
\hline \multicolumn{7}{|c|}{ Field parameters } \\
\hline Air temperature & ${ }^{\circ} \mathrm{C}$ & 21.5 & 25.8 & 26.1 & 33 & 2.92 \\
\hline Dissolved oxygen & $\mathrm{mg} / \mathrm{L}$ & 0.1 & 1.6 & 2.7 & 9.8 & 3.05 \\
\hline $\mathrm{pH}$ & std unit & 3.4 & 6.5 & 6.39 & 9.1 & 1.04 \\
\hline Alkalinity & $\mathrm{mg} / \mathrm{L}$ & $<1$ & 106 & 111 & 355 & 78.7 \\
\hline Hydrogen sulfide & $\mathrm{mg} / \mathrm{L}$ & $<0.01$ & $<0.01$ & 0.085 & 0.24 & 3.61 \\
\hline \multicolumn{7}{|c|}{ Lab analysis } \\
\hline $\mathrm{pH}$ & std unit & 3.5 & 7 & 7 & 9.1 & 0.945 \\
\hline Specific conductance & $\mu \mathrm{S} / \mathrm{cm}$ & 143 & 364 & 463 & 1,830 & 403 \\
\hline Total dissolved solids & $\mathrm{mg} / \mathrm{L}$ & 98.0 & 215 & 295 & 1,220 & 274 \\
\hline Hardness & $\mathrm{mg} / \mathrm{L}$ & 3.4 & 106 & 156 & 885 & 166 \\
\hline \multicolumn{7}{|c|}{ Major ions } \\
\hline Fluoride & $\mathrm{mg} / \mathrm{L}$ & 0.04 & 0.09 & 0.174 & 2.1 & 0.396 \\
\hline Silica & $\mathrm{mg} / \mathrm{L}$ & 7.32 & 12.8 & 12.5 & 21.3 & 3.95 \\
\hline Sulfate & $\mathrm{mg} / \mathrm{L}$ & 0.09 & 28.4 & 74.8 & 720 & 140 \\
\hline \multicolumn{7}{|c|}{ Nutrients } \\
\hline Ammonia as $\mathrm{N}$ & $\mathrm{mg} / \mathrm{L}$ & $<0.01$ & 0.03 & 0.124 & 0.57 & 0.155 \\
\hline $\mathrm{NO}_{3}+\mathrm{NO}_{2}$ as $\mathrm{N}$ & $\mathrm{mg} / \mathrm{L}$ & $<0.04$ & $<0.04$ & 0.291 & 4.14 & 0.819 \\
\hline Nitrate as $\mathrm{N}$ & $\mathrm{mg} / \mathrm{L}$ & $<0.04$ & $<0.04$ & 0.291 & 4.14 & 0.819 \\
\hline Orthophosphate as P & $\mathrm{mg} / \mathrm{L}$ & $<0.004$ & $<0.004$ & 0.024 & 0.199 & 0.048 \\
\hline
\end{tabular}


Table 6B. Statistical summary of analytical results for groundwater samples for 26 sites from the West Virginia southern coalfield province, differentiated by the predominance of the type of mining, for the eastern underground-mined-dominated part of the study area.-Continued

[ft, feet; NAVD88, North American Vertical Datum of 1988; bls, below land surface; in., inches; gal/min, gallons per minute; ${ }^{\circ} \mathrm{C}$, degrees Celsius; mg/L, milligrams per liter; std, standard; $\mu \mathrm{S} / \mathrm{cm}$, microsiemens per centimeter at $25^{\circ} \mathrm{C} ; \mathrm{NTRU}$, nephelometric turbidity ratio units; <, less than; $\mathrm{N}$, nitrogen; $\mathrm{NO}_{3}+\mathrm{NO}_{2}$, nitrate plus nitrite; P, phosphorus; MPN/100 mL, most probable number per 100 milliliters of sample; >, greater than; $\mu \mathrm{g} / \mathrm{L}$, micrograms per liter; nc, all values less than method detection limits therefore mean and median concentrations were not computed; $\mathrm{pCi} / \mathrm{L}$, picocuries per liter; $\mathrm{mg} / \mathrm{kg}$, milligrams per kilogram; E, exponential value]

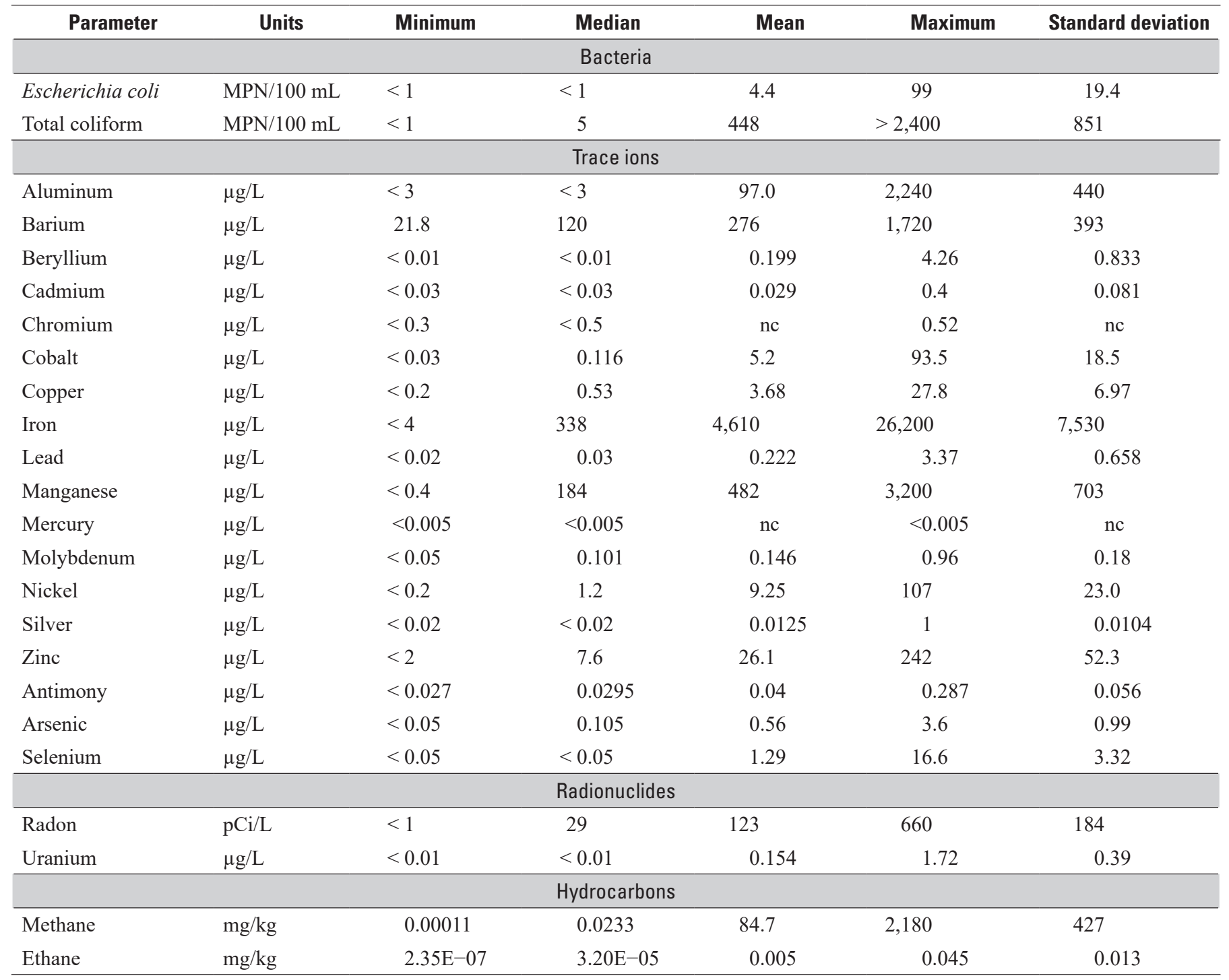


Table 7A. Statistical summary of analytical results for groundwater samples for 10 sites from the West Virginia southern coal-field province, differentiated by geologic formation for the Pocahontas and Bluestone and Princeton Formations.

[ft, feet; NAVD88, North American Vertical Datum of 1988; bls, below land surface; in., inches; gal/min, gallons per minute; ${ }^{\circ} \mathrm{C}$, degrees Celsius; mg/L, milligrams per liter; std, standard; $\mu \mathrm{S} / \mathrm{cm}$, microsiemens per centimeter at $25^{\circ} \mathrm{C} ; \mathrm{NTRU}$, nephelometric turbidity ratio units; <, less than; $\mathrm{N}$, nitrogen; $\mathrm{NO}_{3}+\mathrm{NO}_{2}$, nitrate plus nitrite; $\mathrm{P}$, phosphorus; MPN/100 mL, most probable number per 100 milliliters of sample; >, greater than; $\mu \mathrm{g} / \mathrm{L}$, micrograms per liter; nc, all values less than method detection limits therefore mean and median concentrations were not computed; $\mathrm{pCi} / \mathrm{L}$, picocuries per liter; $\mathrm{mg} / \mathrm{kg}$, milligrams per kilogram; E, exponential value]

\begin{tabular}{|c|c|c|c|c|c|c|}
\hline Parameter & Units & Minimum & Median & Mean & Maximum & Standard deviation \\
\hline \multicolumn{7}{|c|}{ Site characteristics } \\
\hline Well depth & $\mathrm{ft}(\mathrm{bls})$ & 60.4 & 188 & 200 & 400 & 144 \\
\hline Water level & $\mathrm{ft}$ (bls) & 14.7 & 35.8 & 54.2 & 139 & 47.7 \\
\hline Well yield & $\mathrm{gal} / \mathrm{min}$ & 0.4 & 2.86 & 2.88 & 4.89 & 1.54 \\
\hline \multicolumn{7}{|c|}{ Field parameters } \\
\hline Air temperature & ${ }^{\circ} \mathrm{C}$ & 24 & 25.8 & 26.4 & 29.5 & 1.98 \\
\hline Dissolved oxygen & $\mathrm{mg} / \mathrm{L}$ & 0.2 & 3.55 & 4.06 & 9.8 & 3.57 \\
\hline Turbidity & NTRU & 0.5 & 2.2 & 2.28 & 4.6 & 1.31 \\
\hline Alkalinity & $\mathrm{mg} / \mathrm{L}$ & 76.1 & 125 & 162 & 355 & 87.5 \\
\hline Hydrogen sulfide & $\mathrm{mg} / \mathrm{L}$ & 0.01 & 0.01 & 0.03 & 0.24 & 0.075 \\
\hline \multicolumn{7}{|c|}{ Lab analysis } \\
\hline $\mathrm{pH}$ & std unit & 6.7 & 7.25 & 7.42 & 9.1 & 0.692 \\
\hline Specific conductance & $\mu \mathrm{S} / \mathrm{cm}$ & 197 & 491 & 648 & 1,830 & 482 \\
\hline Total dissolved solids & $\mathrm{mg} / \mathrm{L}$ & 126 & 312 & 391 & 1,040 & 271 \\
\hline Hardness & $\mathrm{mg} / \mathrm{L}$ & 3.4 & 179 & 180 & 321 & 87.1 \\
\hline \multicolumn{7}{|c|}{ Major ions } \\
\hline Chloride & $\mathrm{mg} / \mathrm{L}$ & 0.35 & 3.39 & 71.3 & 557 & 175 \\
\hline Fluoride & $\mathrm{mg} / \mathrm{L}$ & 0.05 & 0.095 & 0.304 & 2.1 & 0.632 \\
\hline Silica & $\mathrm{mg} / \mathrm{L}$ & 7.32 & 8.72 & 9.82 & 14 & 2.78 \\
\hline Sulfate & $\mathrm{mg} / \mathrm{L}$ & 0.24 & 64.0 & 63.4 & 170 & 56.5 \\
\hline \multicolumn{7}{|c|}{ Nutrients } \\
\hline Ammonia as $\mathrm{N}$ & $\mathrm{mg} / \mathrm{L}$ & $<0.01$ & $<0.01$ & 0.07 & 0.3 & 0.11 \\
\hline $\mathrm{NO}_{3}+\mathrm{NO}_{2}$ as $\mathrm{N}$ & $\mathrm{mg} / \mathrm{L}$ & $<0.04$ & 0.136 & 0.176 & 0.35 & 0.125 \\
\hline Nitrate as $\mathrm{N}$ & $\mathrm{mg} / \mathrm{L}$ & $<0.04$ & 0.134 & 0.175 & 0.35 & 0.126 \\
\hline Orthophosphate as P & $\mathrm{mg} / \mathrm{L}$ & $<0.004$ & $<0.004$ & 0.02 & 0.098 & 0.03 \\
\hline
\end{tabular}


Table 7A. Statistical summary of analytical results for groundwater samples for 10 sites from the West Virginia southern coal-field province, differentiated by geologic formation for the Pocahontas and Bluestone and Princeton Formations.-Continued

[ft, feet; NAVD88, North American Vertical Datum of 1988; bls, below land surface; in., inches; gal/min, gallons per minute; ${ }^{\circ} \mathrm{C}$, degrees Celsius; mg/L, milligrams per liter; std, standard; $\mu \mathrm{S} / \mathrm{cm}$, microsiemens per centimeter at $25^{\circ} \mathrm{C} ; \mathrm{NTRU}$, nephelometric turbidity ratio units; <, less than; $\mathrm{N}$, nitrogen; $\mathrm{NO}_{3}+\mathrm{NO}_{2}$, nitrate plus nitrite; P, phosphorus; MPN/100 mL, most probable number per 100 milliliters of sample; >, greater than; $\mu \mathrm{g} / \mathrm{L}$, micrograms per liter; nc, all values less than method detection limits therefore mean and median concentrations were not computed; $\mathrm{pCi} / \mathrm{L}$, picocuries per liter; $\mathrm{mg} / \mathrm{kg}$, milligrams per kilogram; E, exponential value]

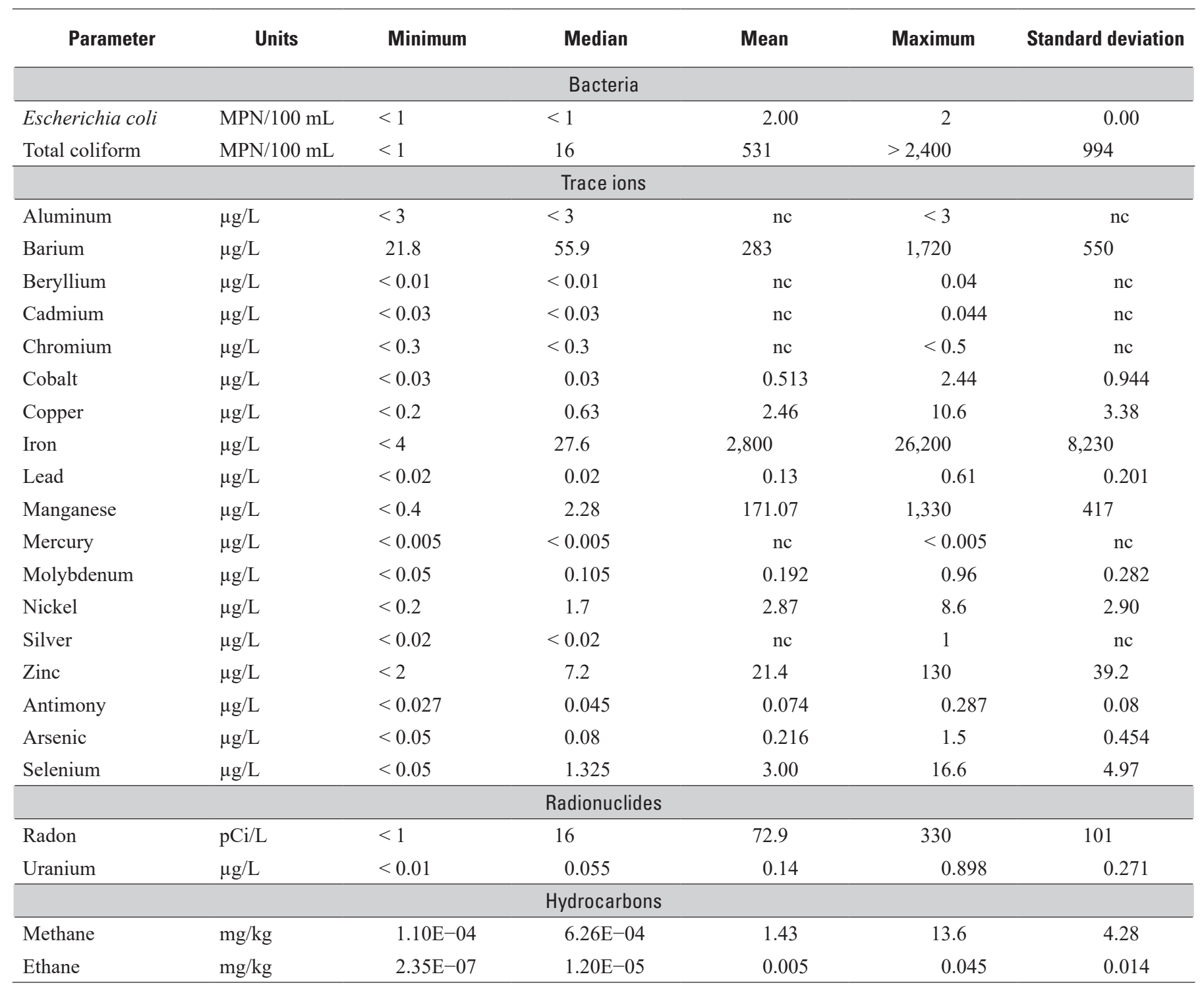


Table 7B. Statistical summary of analytical results for groundwater samples for 16 sites from the West Virginia southern coal-field province, differentiated by geologic formation for the New River Formation.

[ft, feet; NAVD88, North American Vertical Datum of 1988; bls, below land surface; in., inches; gal/min, gallons per minute; ${ }^{\circ} \mathrm{C}$, degrees Celsius; mg/L, milligrams per liter; std, standard; $\mu \mathrm{S} / \mathrm{cm}$, microsiemens per centimeter at $25^{\circ} \mathrm{C} ; \mathrm{NTRU}$, nephelometric turbidity ratio units; <, less than; $\mathrm{N}$, nitrogen; $\mathrm{NO}_{3}+\mathrm{NO}_{2}$, nitrate plus nitrite; P, phosphorus; MPN/100 mL, most probable number per 100 milliliters of sample; >, greater than; $\mu \mathrm{g} / \mathrm{L}$, micrograms per liter; nc, all values less than method detection limits therefore mean and median concentrations were not computed; $\mathrm{pCi} / \mathrm{L}$, picocuries per liter; $\mathrm{mg} / \mathrm{kg}$, milligrams per kilogram; E, exponential value]

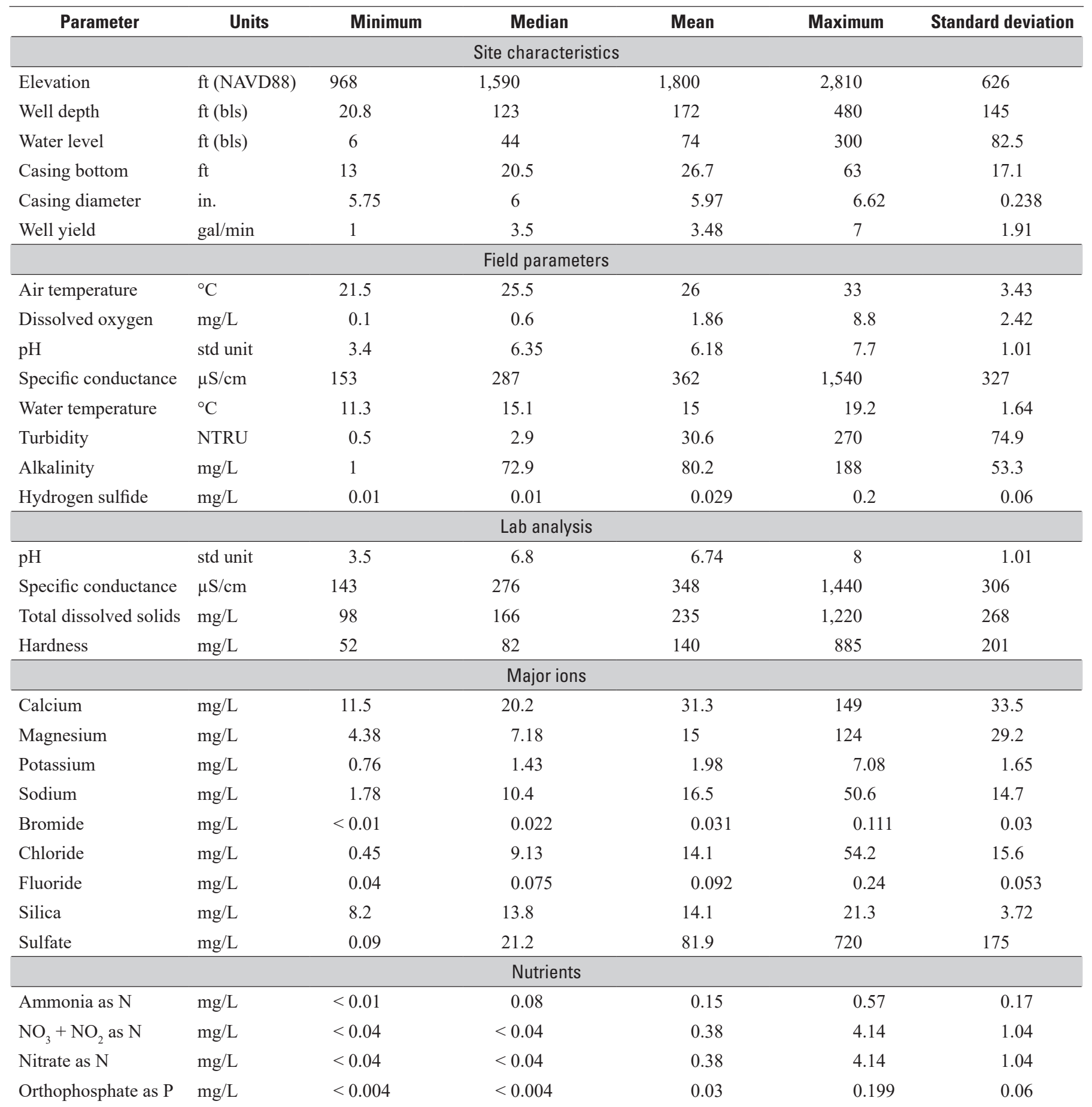


Table 7B. Statistical summary of analytical results for groundwater samples for 16 sites from the West Virginia southern coal-field province, differentiated by geologic formation for the New River Formation.-Continued

[ft, feet; NAVD88, North American Vertical Datum of 1988; bls, below land surface; in., inches; gal/min, gallons per minute; ${ }^{\circ} \mathrm{C}$, degrees Celsius; mg/L, milligrams per liter; std, standard; $\mu \mathrm{S} / \mathrm{cm}$, microsiemens per centimeter at $25^{\circ} \mathrm{C} ; \mathrm{NTRU}$, nephelometric turbidity ratio units; <, less than; $\mathrm{N}$, nitrogen; $\mathrm{NO}_{3}+\mathrm{NO}_{2}$, nitrate plus nitrite; P, phosphorus; MPN/100 mL, most probable number per 100 milliliters of sample; >, greater than; $\mu \mathrm{g} / \mathrm{L}$, micrograms per liter; nc, all values less than method detection limits therefore mean and median concentrations were not computed; $\mathrm{pCi} / \mathrm{L}$, picocuries per liter; $\mathrm{mg} / \mathrm{kg}$, milligrams per kilogram; E, exponential value]

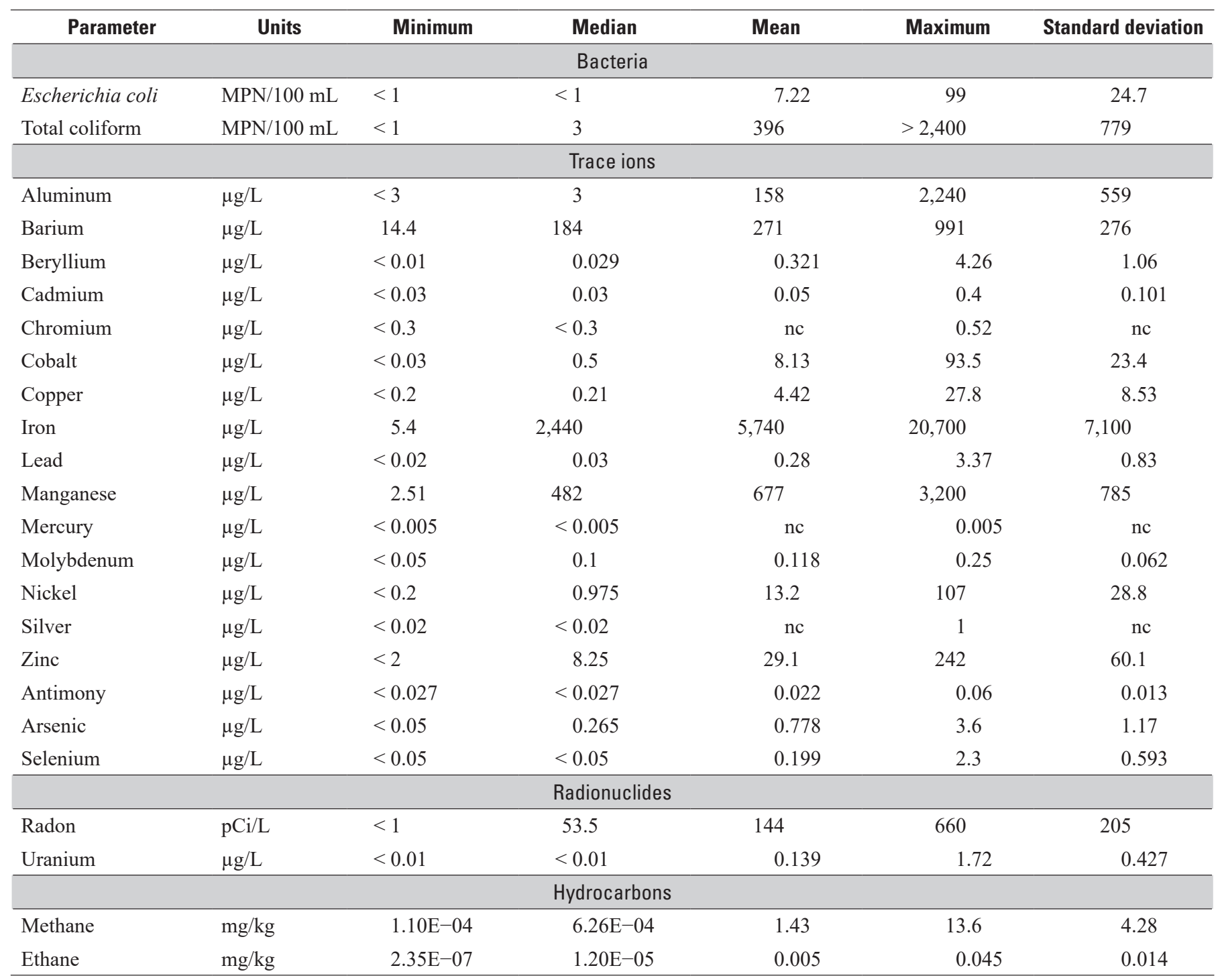


Table 7C. Statistical summary of analytical results for groundwater samples for 34 sites from the West Virginia southern coal-field province, differentiated by geologic formation for the Kanawha and Allegheny Formations.

[ft, feet; NAVD88, North American Vertical Datum of 1988; bls, below land surface; in., inches; gal/min, gallons per minute; ${ }^{\circ} \mathrm{C}$, degrees Celsius; mg/L, milligrams per liter; std, standard; $\mu \mathrm{S} / \mathrm{cm}$, microsiemens per centimeter at $25^{\circ} \mathrm{C} ; \mathrm{NTRU}$, nephelometric turbidity ratio units; <, less than; $\mathrm{N}$, nitrogen; $\mathrm{NO}_{3}+\mathrm{NO}_{2}$, nitrate plus nitrite; $\mathrm{P}$, phosphorus; MPN/100 mL, most probable number per 100 milliliters of sample; >, greater than; $\mu \mathrm{g} / \mathrm{L}$, micrograms per liter; nc, all values less than method detection limits therefore mean and median concentrations were not computed; $\mathrm{pCi} / \mathrm{L}$, picocuries per liter; $\mathrm{mg} / \mathrm{kg}$, milligrams per kilogram; $\mathrm{E}$, exponential value]

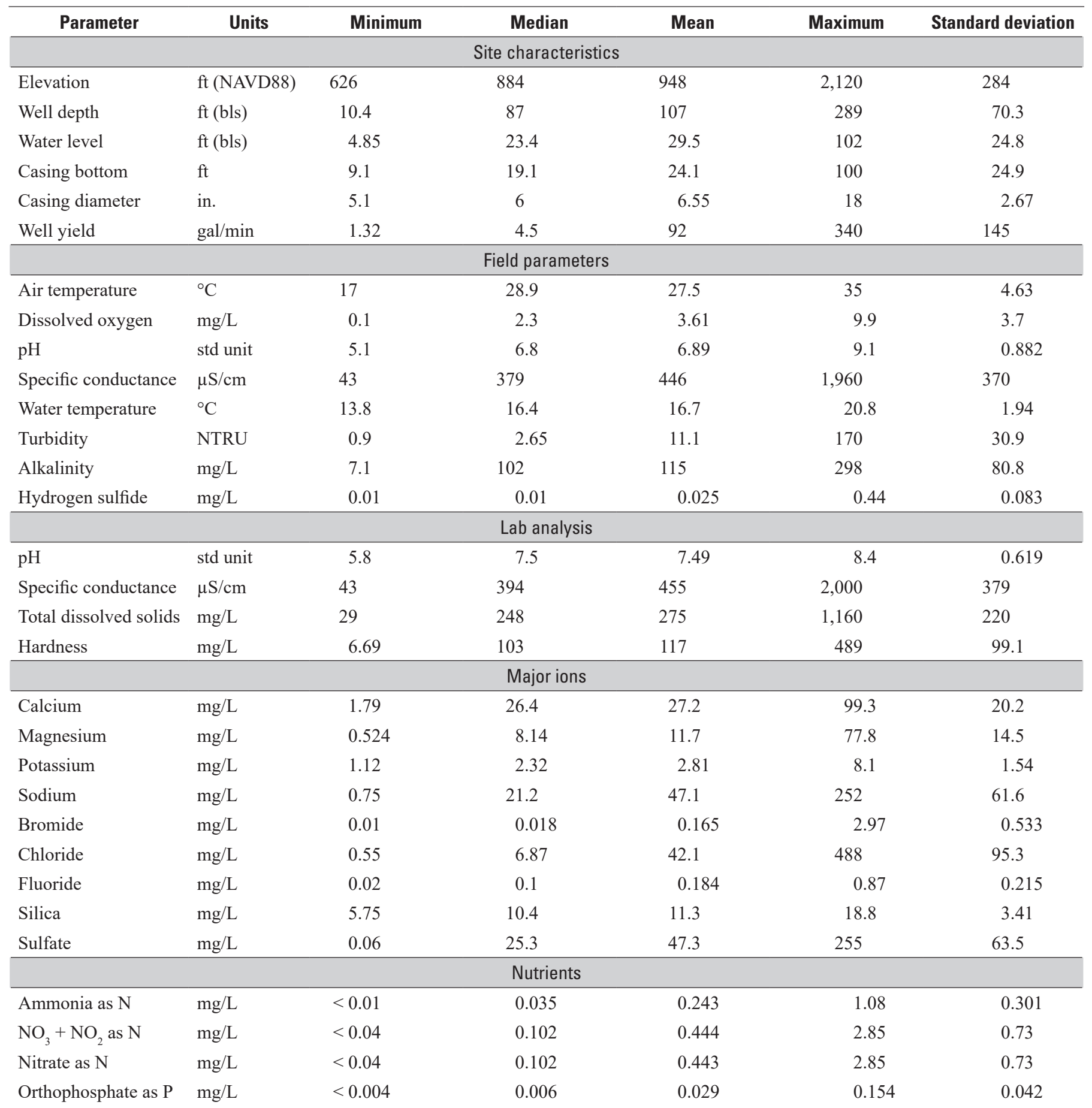


Table 7C. Statistical summary of analytical results for groundwater samples for 34 sites from the West Virginia southern coal-field province, differentiated by geologic formation for the Kanawha and Allegheny Formations.-Continued

[ft, feet; NAVD88, North American Vertical Datum of 1988; bls, below land surface; in., inches; gal/min, gallons per minute; ${ }^{\circ} \mathrm{C}$, degrees Celsius; mg/L, milligrams per liter; std, standard; $\mu \mathrm{S} / \mathrm{cm}$, microsiemens per centimeter at $25^{\circ} \mathrm{C} ; \mathrm{NTRU}$, nephelometric turbidity ratio units; <, less than; $\mathrm{N}$, nitrogen; $\mathrm{NO}_{3}+\mathrm{NO}_{2}$, nitrate plus nitrite; P, phosphorus; MPN/100 mL, most probable number per 100 milliliters of sample; >, greater than; $\mu \mathrm{g} / \mathrm{L}$, micrograms per liter; nc, all values less than method detection limits therefore mean and median concentrations were not computed; $\mathrm{pCi} / \mathrm{L}$, picocuries per liter; $\mathrm{mg} / \mathrm{kg}$, milligrams per kilogram; E, exponential value]

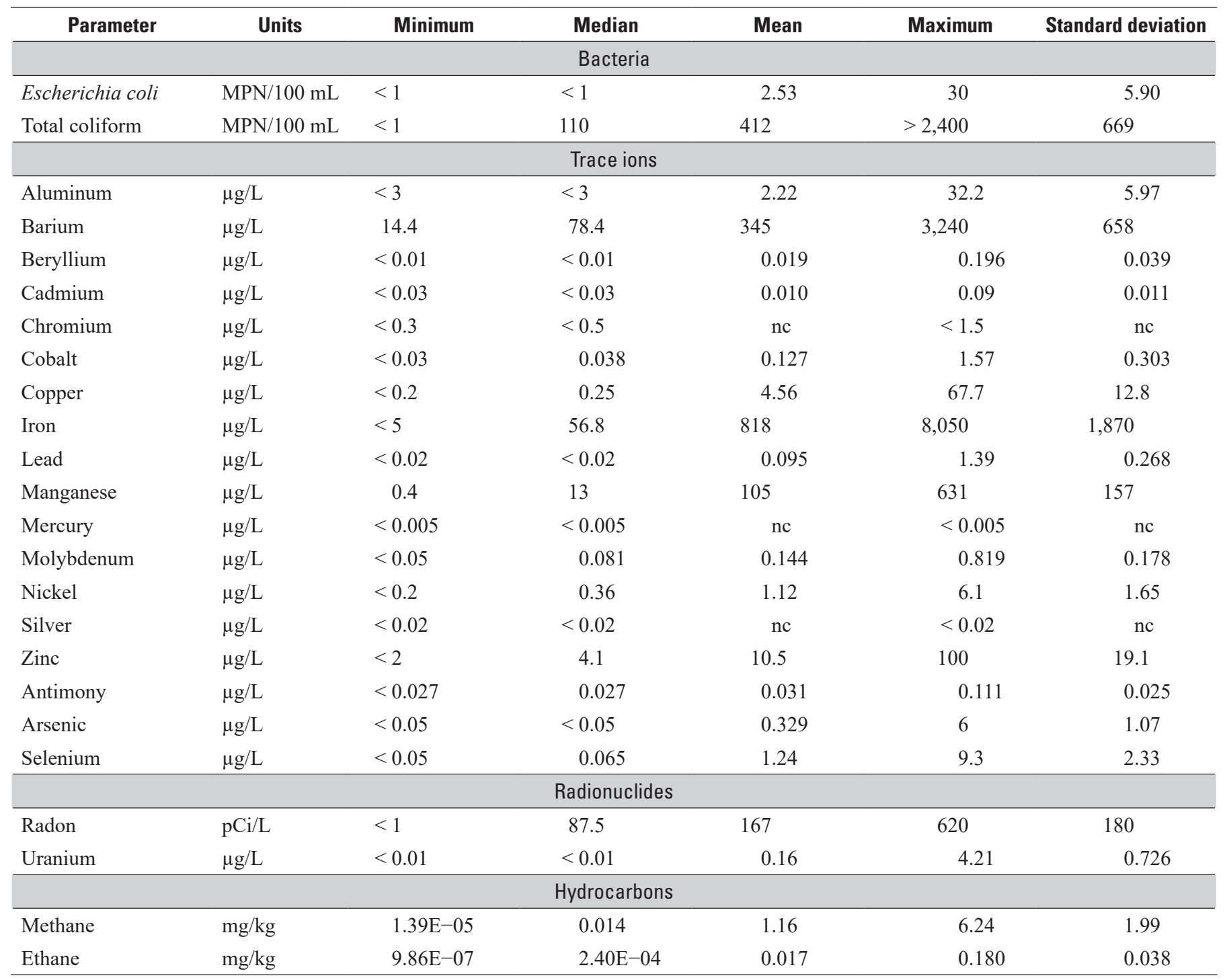




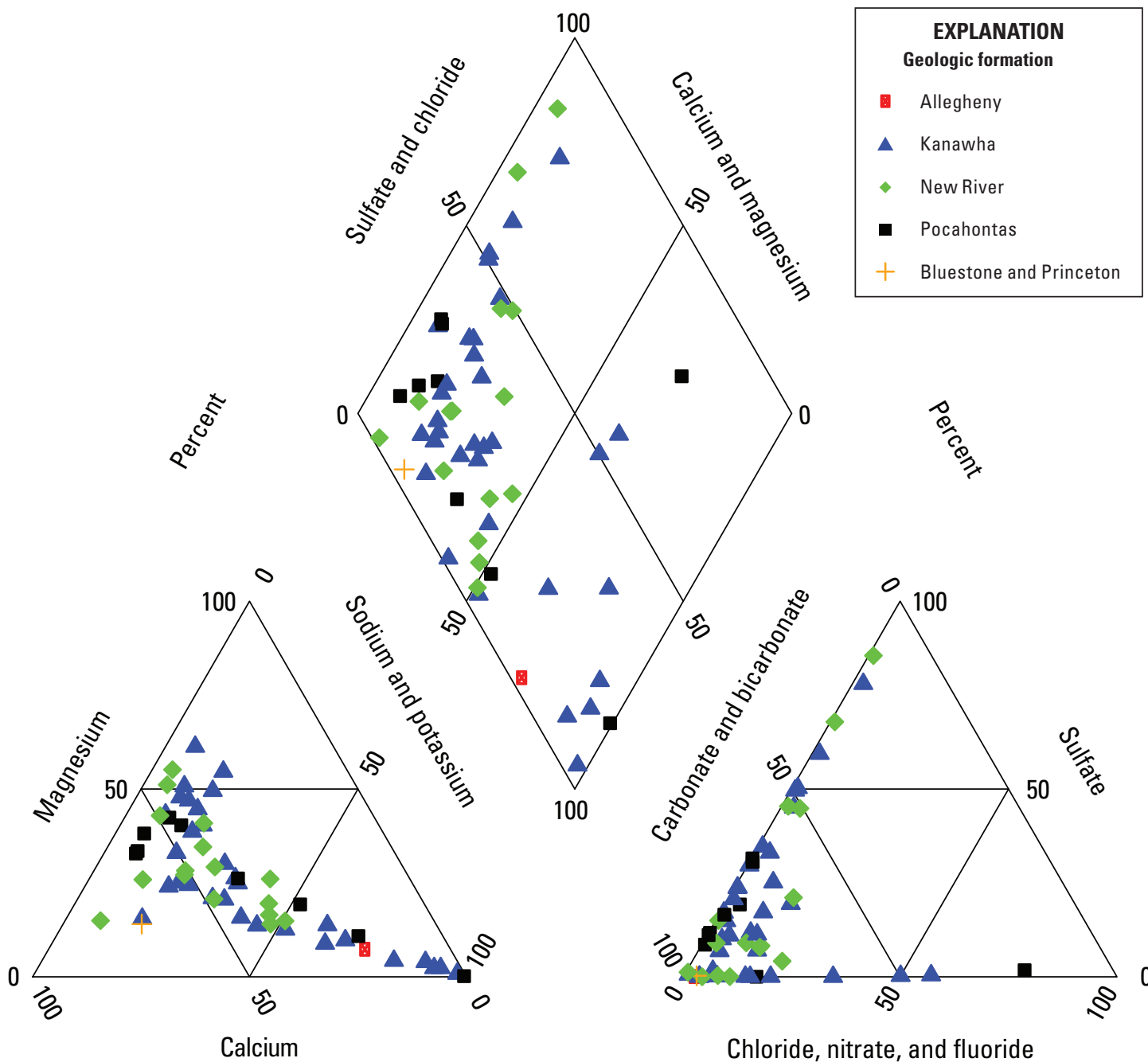

Percent

Figure 7A. Major-ion composition in groundwater samples for 60 sites in the West Virginia southern coal-field province grouped by geologic formation.

\section{Petrographic Data}

To understand what minerals are related to geochemical processes, it is important to correlate the water chemistry with the geochemical composition of the rocks in the study area. Physical geochemical data are usually lacking for most bedrock aquifers in West Virginia. Fortunately, four thin-section samples were collected for petrographic analysis of overburden strata within the Pocahontas Formation in the Elkhorn area as part of a previous study (Kozar and others, 2012), and provide some insight into the mineral composition of overburden strata within the Pocahontas Formation. Unfortunately, there is little similar petrographic data available for the other geologic formations (Kanawha and New River Formations) in the study area, but the overall composition of the rocks in these formations is similar to that of the Pocahontas Formation, with differences in the proportions of sandstone, shale, siltstone, coal, and limestone in the Allegheny Formation.

Thin-section analysis of sample 1 revealed quartz grains (61.3 percent), feldspar grains (16.3 percent), phyllosilicate grains (6.0 percent), micas (6.3 percent), chert grains and clay ( 0.3 percent), siderite ( 7.7 percent), kaolinite and sericite $(0.3$ percent), secondary quartz cement ( 0.7 percent) and trace amounts of pyrite and zircon as well as chert grains $(0.3$ percent) and one tourmaline grain, leaving approximately a 1-percent primary porosity. Thin-section examination of sample 2 revealed abundant mono- and polycrystalline quartz grains (54.7 percent), rock fragments (13.7 percent), and feldspar 


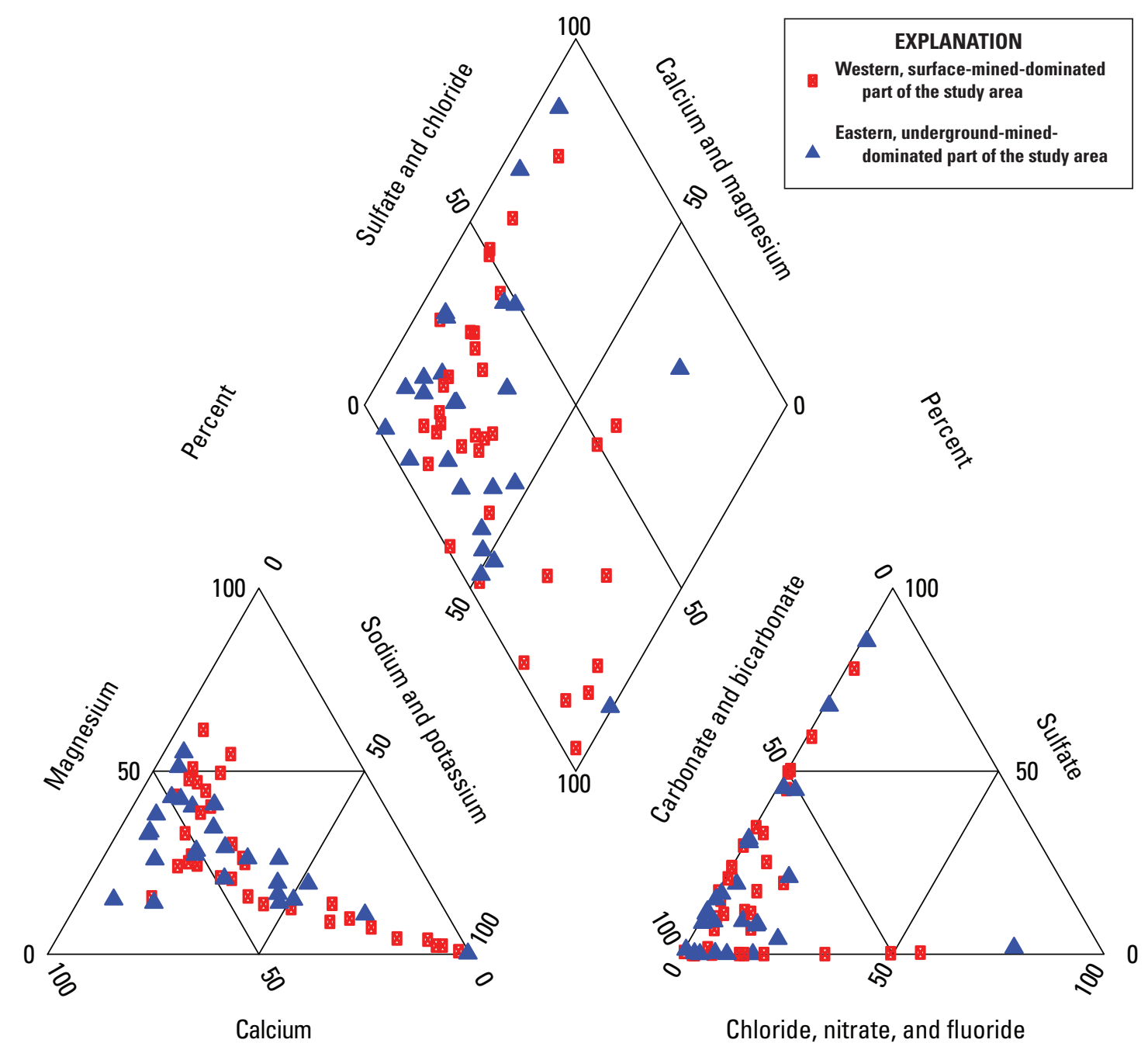

Percent

Figure 7B. Major-ion composition in groundwater samples for 60 sites in the West Virginia southern coal-field province grouped by predominance of the type of mining.

grains (13.0 percent), phyllosilicate grains (0.3 percent), micas ( 8.3 percent), siderite ( 2.3 percent) secondary quartz ( 2.3 percent), pyrite $(0.7$ percent $)$, chert grains ( 0.3 percent $)$, kaolinite ( 0.7 percent) unidentified clays ( 0.3 percent) and approximately a 3.3 -percent porosity. Thin-section examination of sample 3 revealed abundant mono- and polycrystalline quartz grains (60.0 percent), rock fragments (11.0 percent), siderite (10.3 percent), feldspar ( 9.0 percent), micas composed of muscovite ( 3.3 percent) and sericite ( 0.7 percent), and remaining rock constituents including pyrite ( 0.7 percent), secondary quartz overgrowths ( 2.7 percent) and unidentified clays ( 0.3 percent), and a 2.0 -percent porosity. Thin-section examination of sample 4 revealed mono- and polycrystalline quartz grains made up of the majority of the total rock volume (61.0 percent), siderite (14.3 percent), feldspar grains (10.7 percent), rock fragments ( 7.0 percent), and the remainder of the sample was composed of various micas ( 2.7 percent), clays ( 1.3 percent), and minor secondary quartz overgrowths ( 0.33 percent), with a 2.3 -percent porosity.

Whereas similar data were not available for the New River, Kanawha, or Allegheny Formations, the stratigraphic sequence of carboniferous units in southern West Virginia share common traits, due to similar depositional sequences. The Pocahontas Formation is composed of subgraywacke and gray to medium-gray shale intercalated with thin, impure underclay and coal (Arkle and others, 1979). The New River Formation is of a similar composition, composed of subgraywacke, quartzose sandstone, and gray to medium-gray shale, 


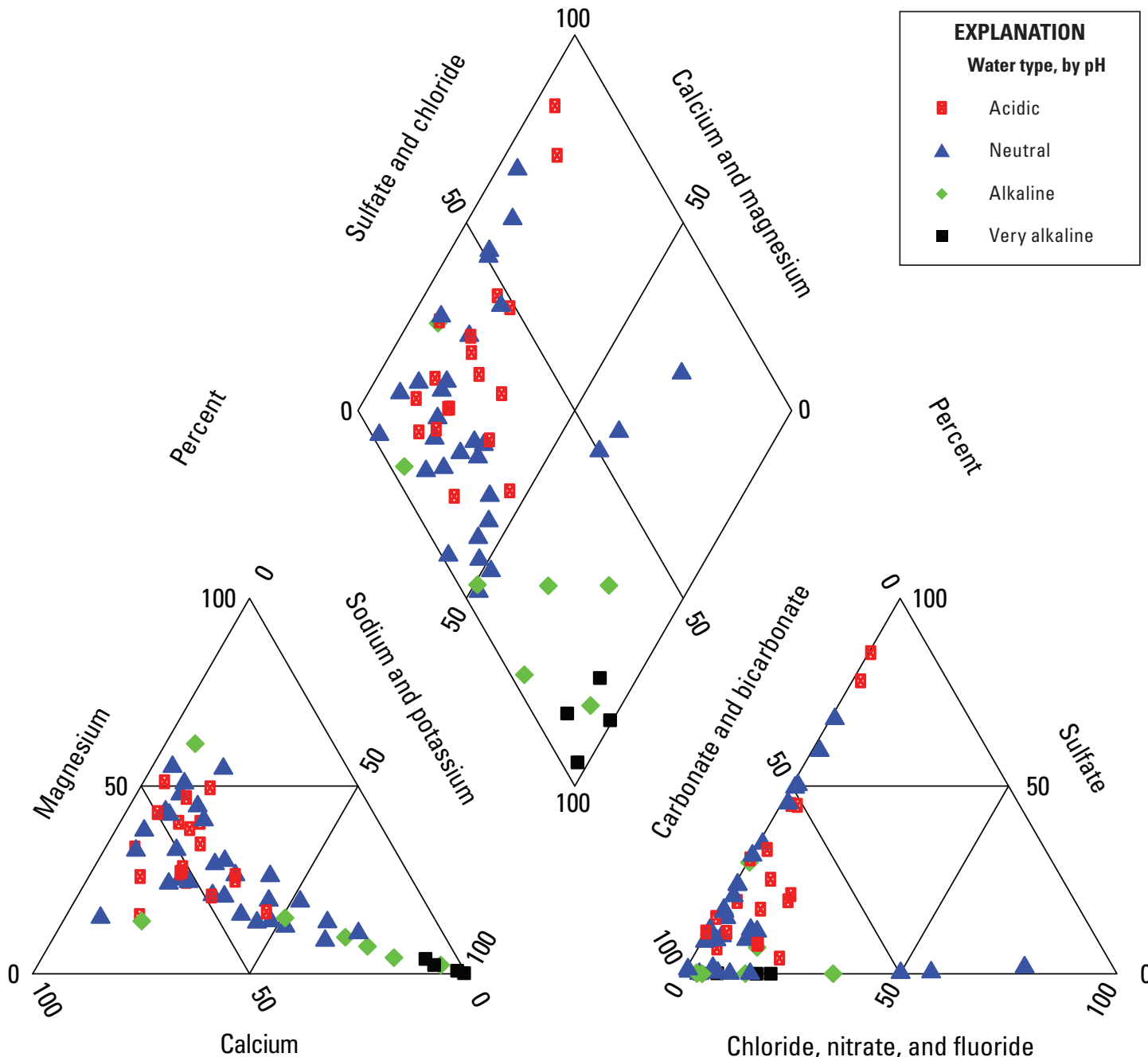

Percent

Figure 7C. Major-ion composition in groundwater samples for 60 sites in the West Virginia southern coal-field province grouped by sample $\mathrm{pH}$.

intercalated with underclay and coal seams (Arkle and others, 1979). The Pocahontas and New River Formations contain little if any appreciable limestone, but a few thin limestone units are present in the younger Kanawha and Allegheny Formations. Siderite nodules are common in the New River Formation, which correlates with the high proportion of siderite observed in the petrographic samples from the Pocahontas Formation in the Elkhorn, West Virginia area (Kozar and others, 2012). The Kanawha Formation is composed of graywacke and light to medium shale and mudstone intercalated with thin carbonate strata and 42 multi-bedded coal seams (Arkle and others, 1979). Finally, the Allegheny Formation is composed of thin to massive bedded subgraywacke and light-gray to gray shale and mudstone, intercalated with underclay and coal (Arkle and others, 1979). The composition of these units, with respect to the proportion of sandstone, shale, claystone, mudstone, fire clays, coals, and thin limestones in the stratigraphic sequence in the contributing area to the well or outfall sampled, as well as the depositional environment of the various geologic formations, likely control much of the water chemistry for the sites sampled. Thus, there can be significant variation in water chemistry between samples even within the same geologic formation, as indicated in the trilinear diagrams for the 60 sampled sites (figs. $7 A-D$ ). Geochemical processes affecting groundwater chemistry and quality are discussed further in the Geochemistry section of this report. 


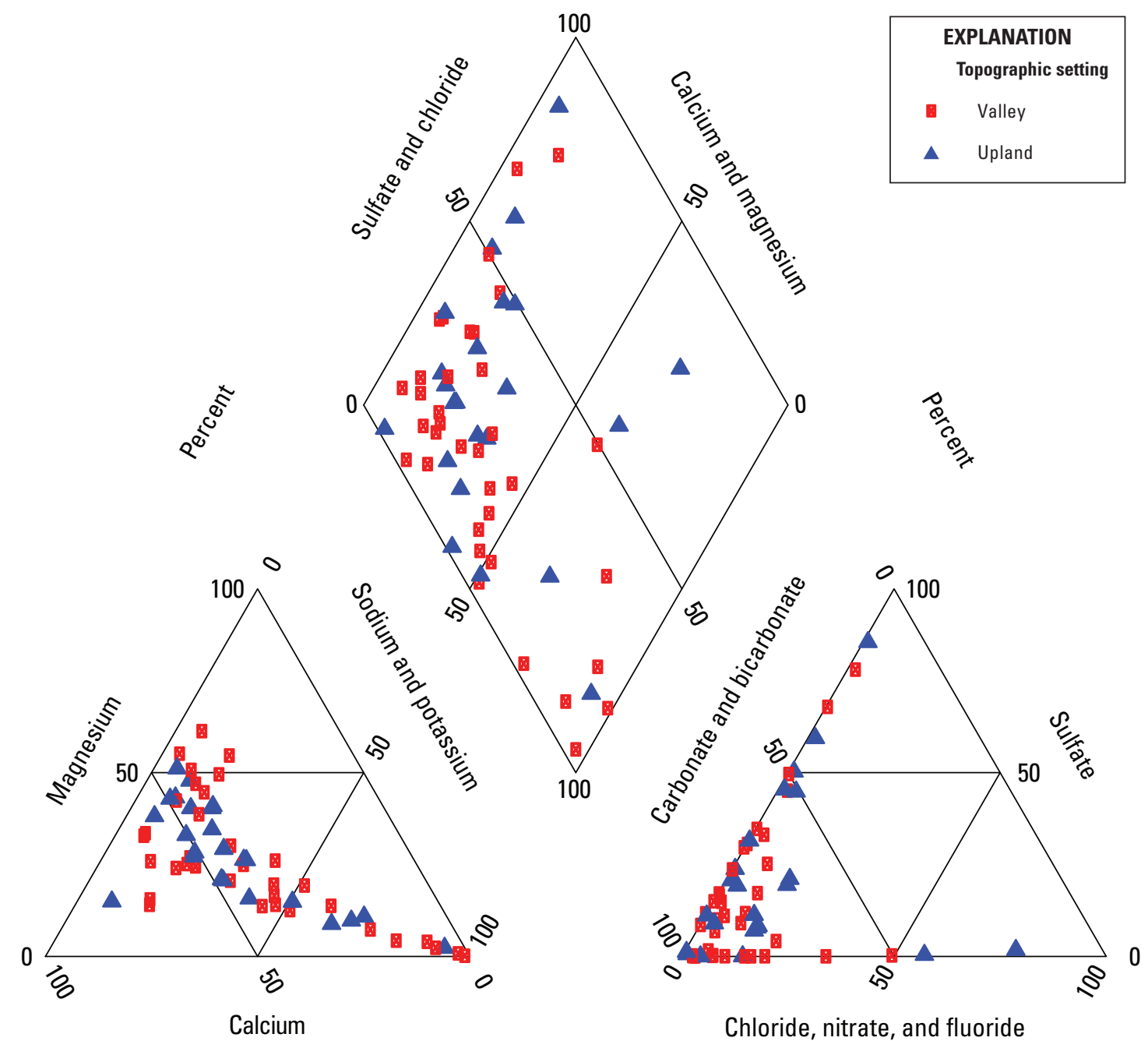

Percent

Figure 7D. Major-ion composition in groundwater samples for 60 sites in the West Virginia southern coal-field province grouped by topographic setting.

\section{Major lons and Total Dissolved Solids (TDS)}

The primary constituents responsible for the majority of TDS content in the water from the sites sampled are derived from calcium, magnesium, sodium, potassium, and bicarbonate, and for selected sites, from sulfate and chloride, as shown in figure $7 A$ and figure 8 . It is difficult to assess differences in overall water chemistry with respect to geologic formation by examination of the trilinear diagram (fig. $7 A$ ), but the boxplots of data distributions shown in figure 8 and the results of the Wilcoxon signed-rank test of statistical comparison of populations by constituent indicate that the overall TDS, calcium, magnesium, and bicarbonate content is higher in the Pocahontas Formation than in the younger New River and Kanawha Formations. Concentrations of sodium are highest in groundwater sampled from the Kanawha Formation. Median concentrations of calcium, magnesium, sodium, potassium, and TDS for sites in the Pocahontas Formation were 41.8, $18.6,15,2.10$, and $312 \mathrm{mg} / \mathrm{L}$, respectively (table $7 A$ ). The distribution of the major ions is similar for the New River and Kanawha Formations, with median calcium, magnesium, sodium, potassium, and TDS for sites in the New River Formation of 20.2, 7.18, 10.41 .43 , and $166 \mathrm{mg} / \mathrm{L}$ (table $7 B$ ), respectively, and concentrations of $26.4,8.14,21.2,2.32$, and $248 \mathrm{mg} / \mathrm{L}$ respectively, for sites in the Kanawha Formation (table 7A).

The trilinear diagram in figure $7 C$ shows the overall water chemistry in relation to $\mathrm{pH}$ for the sites sampled, and classifies the waters sampled as alkaline or acidic based on pH (fig. 7C). Most water samples classified as alkaline or very 
alkaline have a sodium + potassium bicarbonate water type. Water samples classified as acidic have a calcium + magnesium bicarbonate type water.

Comparison of a boxplot (fig. 8) and summary statistics (tables $6 A$ and $6 B$ ) of the distribution of major ions with respect to the western surface-mine-dominated and eastern underground-mine-dominated areas did not reveal any significant differences in chemical concentrations with respect to predominant mining activity (surface or underground) or geology. Median concentrations of calcium, magnesium, sodium, potassium, and TDS for the eastern undergroundmine-dominated part of the study area were 26.5, 8, 12.2, 1.6 and $215 \mathrm{mg} / \mathrm{L}$, respectively (table $6 B$ ), and concentrations of calcium, magnesium, sodium, potassium, and TDS for the western surface-mine-dominated part of the study area were $24.2,7.47,20.8,2.41$, and $248 \mathrm{mg} / \mathrm{L}$, respectively (table $6 A$ ).

\section{Iron, Manganese, and Sulfate}

The more problematic chemical constituents in groundwater in areas of active or legacy coal mining are typically iron, manganese, sulfate, and $\mathrm{pH}$ (Chambers and others, 2012). These constituents amongst other less important trace metals are responsible for most of the acid-mine-drainage related constituents found in groundwater within the study area. Iron and manganese are not depicted in the trilinear diagrams comparing geologic formations (figs. $7 A$ and $7 B$ ) as they are not typically dominant ions with respect to the overall TDS of groundwater. However, waters with extremely low $\mathrm{pH}$ can be problematic with respect to corrosion of galvanized and copper water lines, boiler scale deposits, and poor taste of the water. Where mine outfall discharges of groundwater from abandoned mines enter streams, degradation of the stream
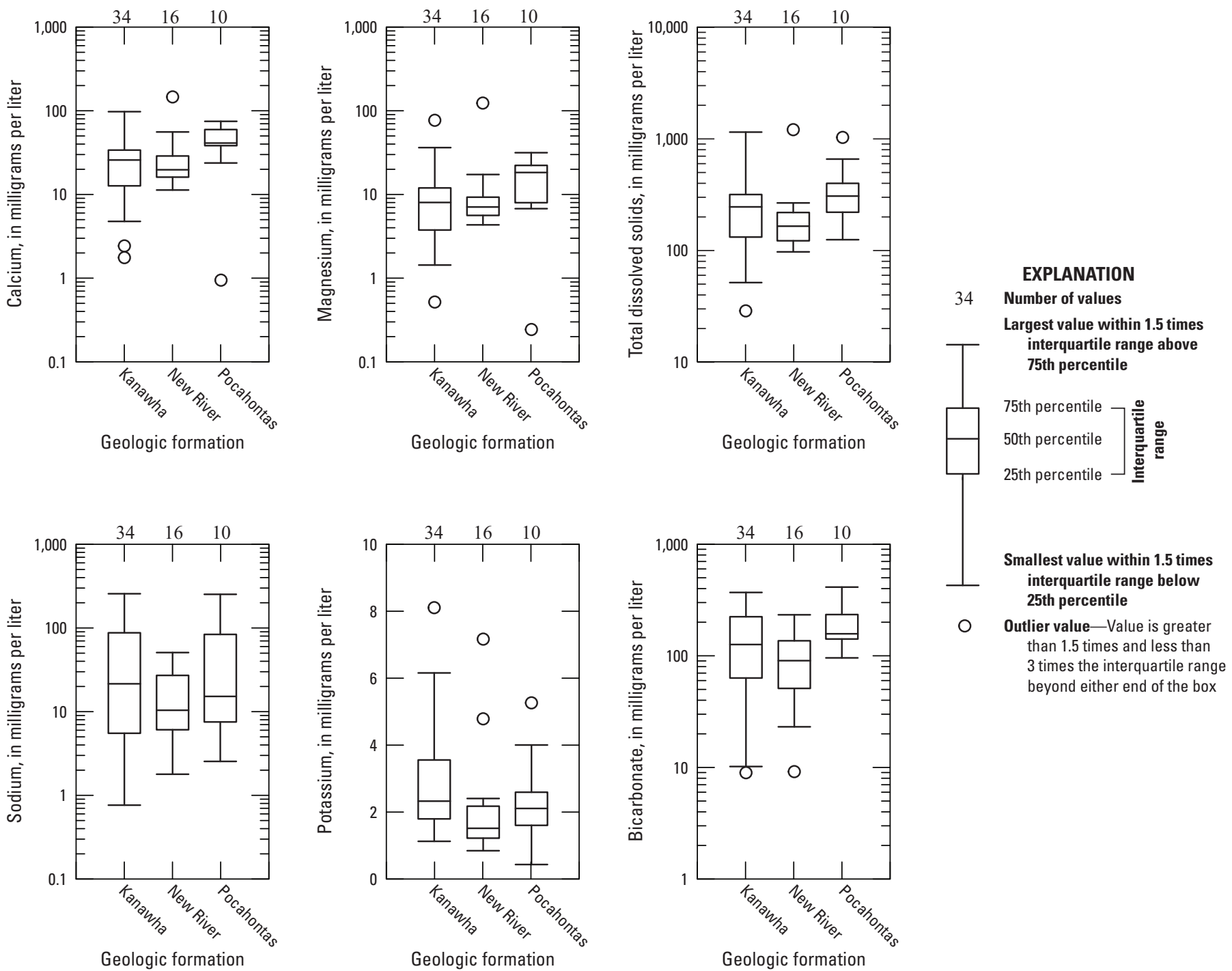

interquartile range below

1.5 times and less than

Figure 8. Distribution of major-ion concentrations responsible for most total dissolved solids in groundwater samples for 60 sites sampled in the West Virginia southern coal-field province, grouped by geologic formation. 
with respect to iron staining and aquatic effects on stream biota and resultant fish populations can occur.

Boxplots of iron, manganese, sulfate, and $\mathrm{pH}$ show that there are differences in the median concentrations for the sites in the various geologic formations (fig. 9). Median concentrations of iron, manganese, sulfate, and $\mathrm{pH}$ values for sites sampled in the Pocahontas Formation were $27.6 \mu \mathrm{g} / \mathrm{L}$, $2.28 \mu \mathrm{g} / \mathrm{L}, 64.0 \mathrm{mg} / \mathrm{L}$, and 6.5 standard units, respectively (table $7 A$ ). Median concentrations of iron, manganese, sulfate, and median $\mathrm{pH}$ values for sites sampled in the New River Formation were $2,440 \mu \mathrm{g} / \mathrm{L}, 482 \mu \mathrm{g} / \mathrm{L}, 21.15 \mathrm{mg} / \mathrm{L}$, and 6.35 standard units, respectively (table $7 B$ ). Median concentrations of iron, manganese, sulfate, and median $\mathrm{pH}$ values for sites sampled in the Kanawha Formation were $56.8 \mu \mathrm{g} / \mathrm{L}, 13 \mu \mathrm{g} / \mathrm{L}$, $25.30 \mathrm{mg} / \mathrm{L}$, and 6.8 standard units, respectively (table 7C). The concentrations of iron and manganese in the New River
Formation were statistically significantly higher than the concentrations in either the Pocahontas or Kanawha Formations.

Median concentrations of iron, manganese, sulfate, and median $\mathrm{pH}$ values for sites sampled in the western surfacemine-dominated part of the study area were $56.8 \mu \mathrm{g} / \mathrm{L}$, $13.1 \mu \mathrm{g} / \mathrm{L}, 24.5 \mathrm{mg} / \mathrm{L}$, and 6.8 standard units, respectively (table 6A), and median concentrations of the same constituents and median $\mathrm{pH}$ values sampled in the eastern surface-minedominated part of the study area were $338 \mu \mathrm{g} / \mathrm{L}, 184 \mu \mathrm{g} / \mathrm{L}$, $28.4 \mathrm{mg} / \mathrm{L}$, and 6.5 standard units, respectively (table $6 B$ ). Comparison of the distribution of common mining-related constituents between the western surface-mined areas and the eastern underground-mined areas (tables $6 A$ and $6 B$ ) indicates that chemical concentrations of iron and manganese were statistically significantly different. It is not clear, however, whether there is a significant difference in these constituents
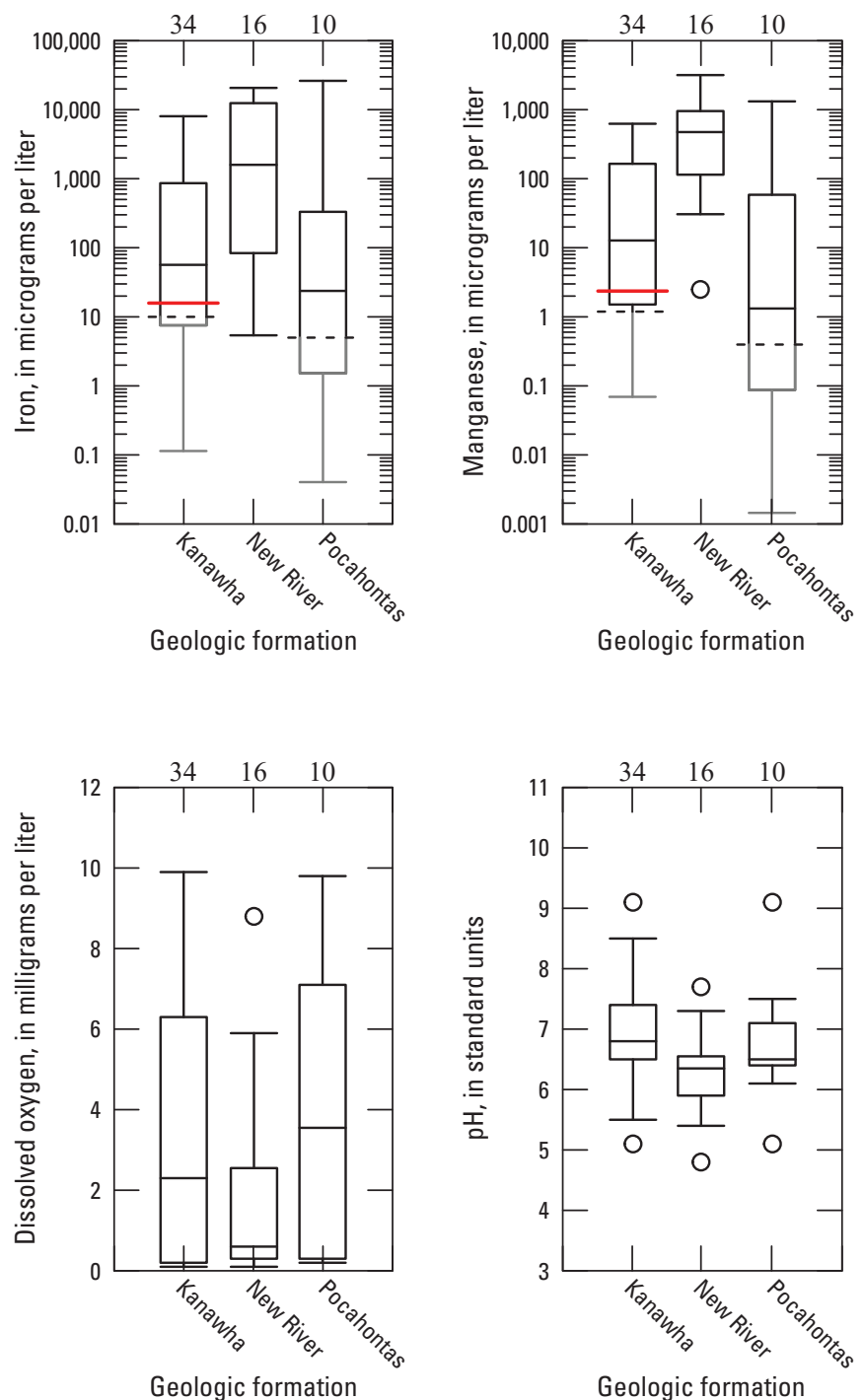

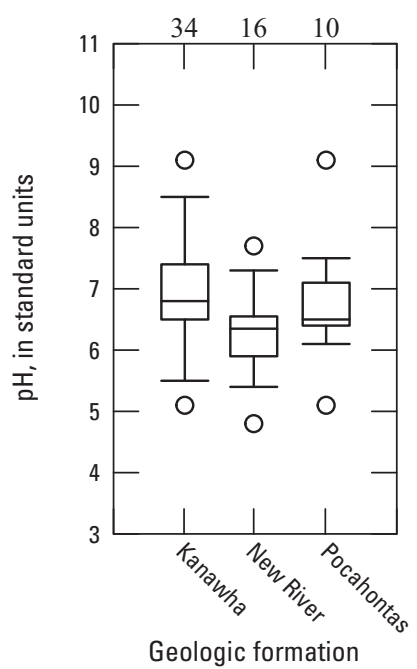

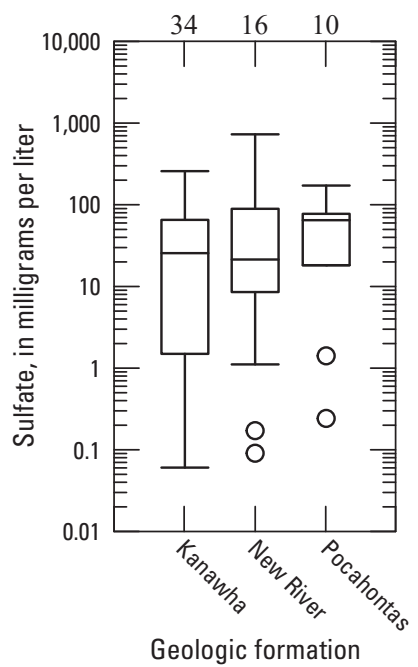

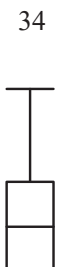

EXPLANATION

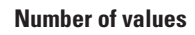

Largest value within 1.5 times interquartile range above

75th percentile

75th percentile $\neg$ 50th percentile

Imputed value

- - - - Detection limit

Smallest value within 1.5 times interquartile range below 25th percentile

$0 \quad$ Outlier value - Value is greater than 1.5 times and less than 3 times the interquartile range beyond either end of the box

Figure 9. Distribution of iron, manganese, sulfate, dissolved oxygen, and field $\mathrm{pH}$ in groundwater samples for 60 sites in the West Virginia southern coal-field province, grouped by geologic formation. 
with respect to the dominant type of mining activity in the eastern underground and western surface-mined areas, as the geology has been shown to affect the overall chemistry of the waters sampled.

Since the aquifer in the western surface-mine-dominated areas is composed primarily of water derived from the Kanawha Formation, and to a lesser extent, the Allegheny Formation, and the aquifer in the eastern underground-mine-dominated areas is composed primarily of water derived from the Pocahontas and New River Formations, and to a lesser extent, the Bluestone and Princeton Formations, the median chemical concentrations and overall chemistry of the groundwater in the study area are likely due to the composition of the rock in the various geologic formations rather than the type of mining. A previous study of groundwater-quality effects from reclaimed surface mines in West Virginia and Pennsylvania (McAuley and others, 2006) indicated that concentrations of mine-related constituents such as iron, manganese, sulfate, TDS, $\mathrm{pH}$, and other constituents rapidly returned to background concentrations within a $1,000-\mathrm{ft}$ distance of reclaimed surface mines. As most sites sampled were greater than $1,000 \mathrm{ft}$ from active or reclaimed surface mines, it is not likely that a signature related to the type of mining would be evident in the data collected for this study, and therefore, additional data would be needed to fully assess the difference in groundwater quality between areas dominated by surface mining and underground mining.

\section{Constituents of Brines and Sandstones}

A boxplot of the distribution of sodium, chloride, barium, bromide, and silica shows the distribution of constituents that are indicative of a brine signature (fig. 10). Generally, there is

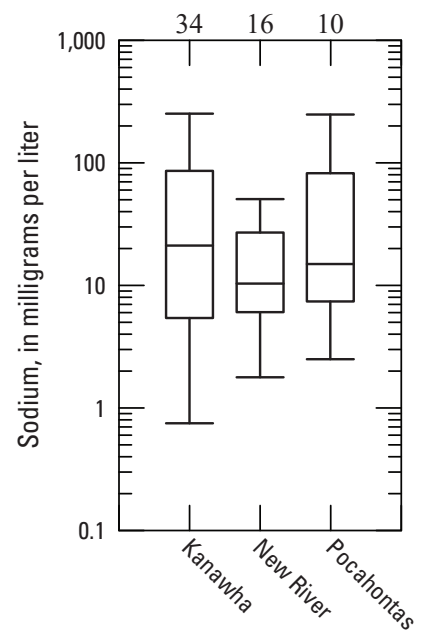

Geologic formation

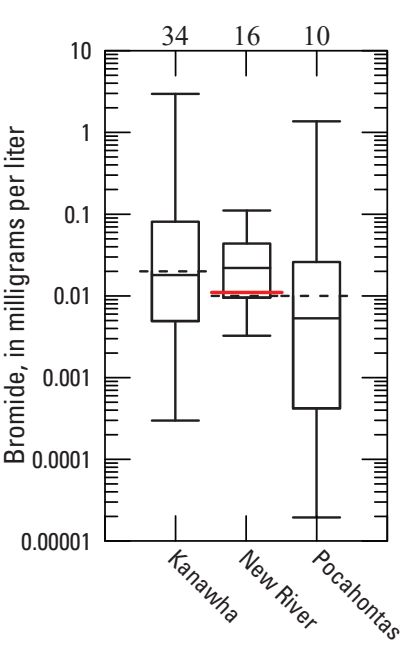

Geologic formation

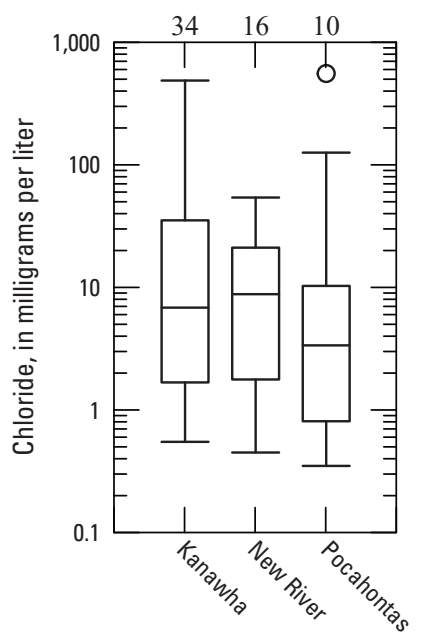

Geologic formation

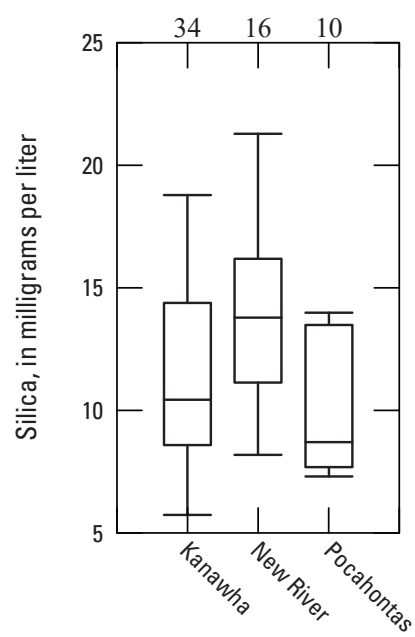

Geologic formation

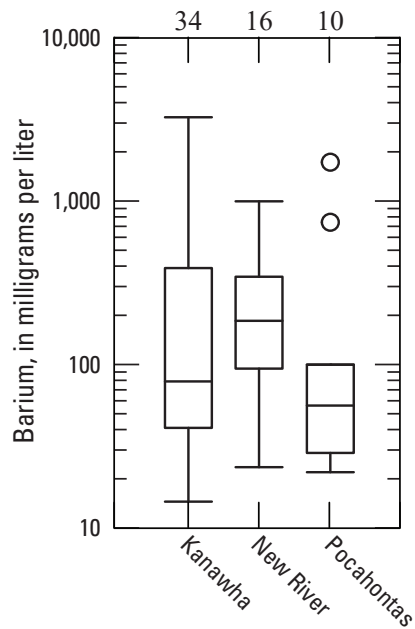

Geologic formation

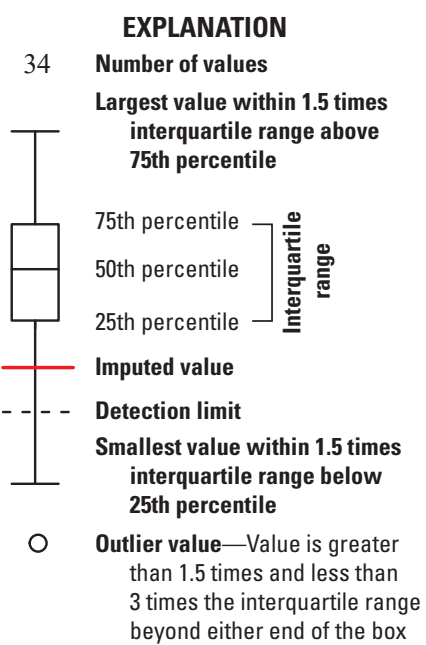

Figure 10. Distribution of major-ion concentrations, commonly found in brine or road salt, in groundwater samples for 60 sites in the West Virginia southern coal-field province, grouped by geologic formation. 
not a lot of variation with respect to concentrations of sodium, chloride, and bromide (fig. 10) in relation to geologic formation or topographic setting, and statistical comparisons of concentrations of these constituents with respect to geologic formations or topographic setting did not indicate any statistically significant relations for these constituents (table 5). The New River Formation did have higher median concentrations of barium and silica, however. The median barium concentration for the New River Formation was $184 \mu \mathrm{g} / \mathrm{L}$, whereas the median barium concentrations for the Kanawha and Pocahontas Formations were 78.4 and 55.9 and $\mu \mathrm{g} / \mathrm{L}$ respectively. The source of the barium is unknown, as there is little physical geochemical data for the study area, other than what was collected in McDowell County for a recent study (Kozar and others, 2012). In addition to sulfate minerals, such as barite and barite-celestite solid solutions, barium may be a trace component in carbonate minerals or adsorbed by manganese oxides (Hanshaw and Back, 1979). Regardless of the potential source, the New River Formation had higher median manganese and barium concentrations than either the Kanawha or Pocahontas Formations.

Silicon is second only to oxygen in abundance within the Earth's crust (Hem, 1992), and is commonly reported as silica in the form silicon oxide $\left(\mathrm{SiO}_{2}\right)$. Silica is therefore common in many silicate oxide and hydroxide minerals such as quartz, kaolinite, potassium feldspars, beryl, and forsterite (Hem, 1992). Quartz and other silicate minerals are commonly found in high proportions in sandstone. The New River Formation also had higher median silica concentrations than the Kanawha and Pocahontas Formations. The median silica concentration for the New River Formation (table 7B) was $13.8 \mathrm{mg} / \mathrm{L}$, and the median silica concentrations for the Kanawha and Pocahontas Formations (tables $7 C$ and $7 A$ ) were 10.45 and $8.72 \mathrm{mg} / \mathrm{L}$, respectively. It should be noted that petrographic data for samples collected as part of another investigation (Kozar and others, 2012) within the study area showed that silica is a dominant mineral in all the rock types analyzed, including shale, claystones and mudstones, as well as the sandstones.

\section{Radioactive Constituents}

Boxplots of the radionuclides, uranium and radon (fig. 11), showed that median radon concentrations were highest in the Kanawha Formation and lowest in the Pocahontas Formation; the concentrations in the New River Formation were in the intermediate range. There were no statistically significant differences in radon between any of the geologic formations, topographic settings, or the dominant mining types in the southeastern and northwestern regions of the study area. Of the 12 sites at or exceeding the $300-\mathrm{pCi} / \mathrm{L}$ drinking-water standard, 8 (67 percent of MCL exceedances) were for sites deriving water from the Kanawha Formation, 3 (25 percent of MCL exceedances) were for sites deriving water from the New River Formation, and only 1 site was for water deriving from the Pocahontas Formation (8 percent of proposed MCL exceedances). Uranium was statistically higher in the Pocahontas Formation when compared to concentrations for groundwater sampled in the Kanawha Formation, but the median values for both the Pocahontas and New River Formations were not high (0.055 and less than $0.01 \mu \mathrm{g} / \mathrm{L}$, respectively).

A correlation matrix (appendix 1) was developed and a multivariate statistical analysis of all available data was analyzed using PCA (PCA and correlation matrix are discussed in detail later in the Geochemistry section of this report). Radon had a very weak correlation with nitrate but did not correlate
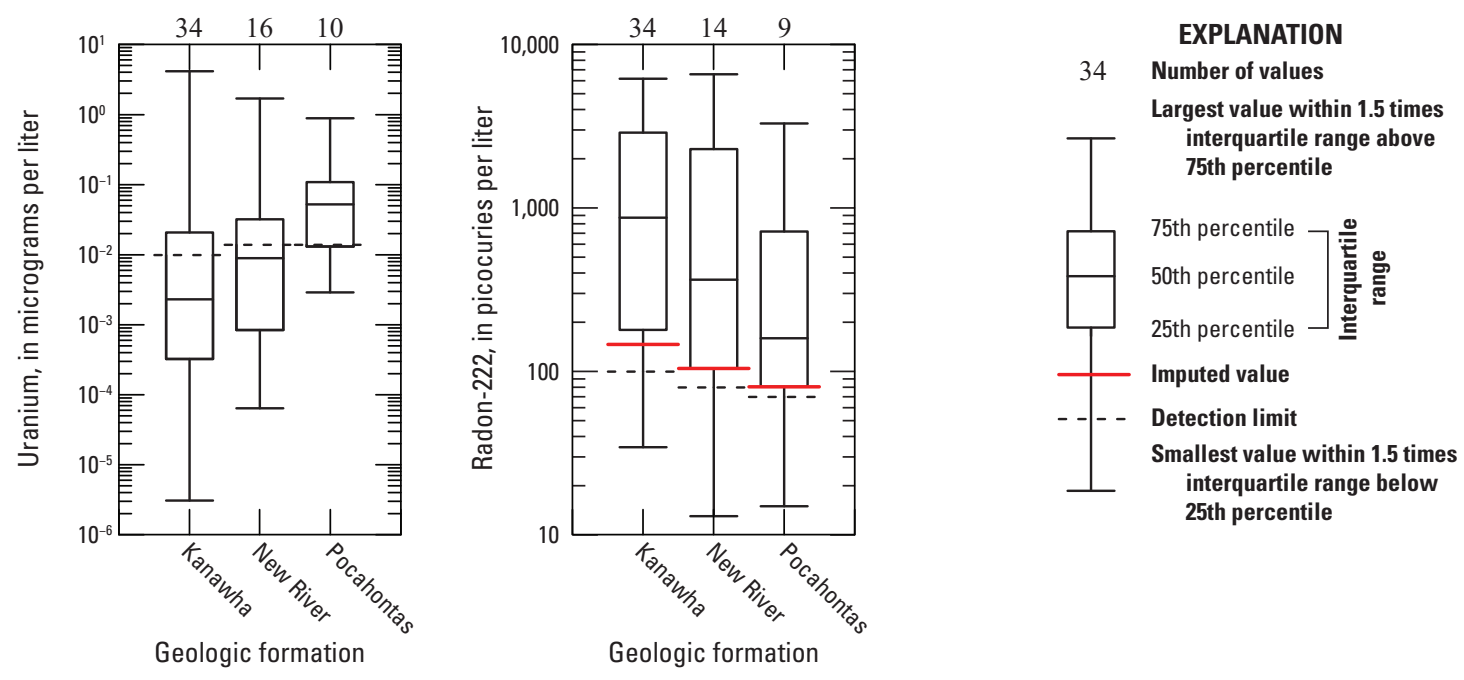

Figure 11. Uranium and radon concentrations in groundwater samples for 60 sites in the West Virginia southern coal-field province, grouped by geologic formation. 
with any other chemical constituent or physical variable, or with topographic setting, well depth, or other variables such as mining type (appendix 1). A previous statewide study of groundwater quality in West Virginia showed that radon concentrations are present in higher concentrations in the younger carboniferous units (Chambers and others, 2012), including the Allegheny Formation. Generally, the proportion of shale, siltstone, and mudstone decreases with geologic age, with the younger carboniferous geologic groups composed of a higher proportion of dark shales than older carboniferous geologic formations such as the Pocahontas and New River Formations. Radon is commonly derived from dark shales (Otton, 1992), and it is likely that the radon is derived from the geologic sequences with a higher proportion of dark shales, such as shale layers within the Kanawha Formation.

Uranium was positively correlated with dissolved oxygen, hardness, calcium, magnesium, potassium, sulfate, nitrate, and inversely correlated with barium, iron, manganese, ammonia, silica, chloride, and bromide. Due to the very low concentrations of uranium typically found in the sampled waters and because the median concentrations for uranium were at or below the method detection limit, correlation of the distribution of uranium with respect to geologic formation or other variables was deemed to be weak at best, except for uranium loads on a few of the principal components, which are discussed later in the Geochemistry section of this report.

\section{Groundwater Quality in Relation to Site Type and Topographic Setting}

A trilinear plot (fig. 7D) differentiating the sites sampled based on topographic position, either upland hillside and hilltop sites or lowland valley sites, did not reveal any obvious trends in chemistry with respect to topographic setting. Two upland wells ( 3.3 percent of the 60 sites sampled) had a sodium + potassium and sulfate + chloride water type, but these two sites appeared to be outliers within the data. Most sites sampled ( 40 of 60 sites or 66.7 percent) exhibited a calcium + magnesium bicarbonate type of water, 12 of 60 sites (20 percent) exhibited a sodium + potassium bicarbonate type of water, and 6 of 60 sites ( 10.0 percent) exhibited a calcium + magnesium sulfate + chloride type of water. Valley wells predominantly exhibited a calcium + magnesium bicarbonate type of water.

Examination of boxplots of constituents for upland wells and mine outfalls compared to valley wells and outfalls did not reveal any major differences in groundwater quality, other than some minor differences for bromide, manganese, radon, silica, and aluminum. It is unlikely that any of these constituents are statistically significant with the exception of possibly aluminum, which is several orders of magnitude higher in valleys than in uplands (fig. 12). The p-values for Wilcoxon signedrank tests (table 5) indicate that the only constituents that had a statistical difference between upland sites (hilltops and hillsides) and valley sites were silica and trace elements such as beryllium, cobalt, and nickel. The median silica concentrations for sites sampled in upland settings was $13.45 \mathrm{mg} / \mathrm{L}$, and the median silica concentration for sites sampled in valleys was $10.24 \mathrm{mg} / \mathrm{L}$.

Sites sampled for this study included 46 wells and 14 mine outfalls. The chemistry in outfalls and wells is often quite different, with outfalls being dominated by much higher dissolved oxygen content than deeper wells (fig. 13A). The dissolved oxygen content is the primary component driving the oxidation and reduction of minerals, and the precipitation of minerals that are saturated or supersaturated with respect to various cations and anions. This was the case for sites sampled for this study as the median dissolved oxygen concentration was $8.75 \mathrm{mg} / \mathrm{L}$ for the sampled outfalls and $0.4 \mathrm{mg} / \mathrm{L}$ for the sampled wells (tables $8 A$ and $8 B$, respectively). Median concentrations of sulfate and selenium were much higher in waters from the outfalls sampled (table $8 A$ ), with median concentrations of $73.8 \mathrm{mg} / \mathrm{L}$ and $2.35 \mu \mathrm{g} / \mathrm{L}$, respectively, than concentrations for the same constituents in waters from the wells sampled, which had median concentrations of $18.3 \mathrm{mg} / \mathrm{L}$ and less than the $0.05-\mu \mathrm{g} / \mathrm{L}$ method detection limit, respectively (table $8 B$ ). The maximum selenium concentration was for a well, with a concentration of $16.6 \mu \mathrm{g} / \mathrm{L}$, which was far below the $50-\mu \mathrm{g} / \mathrm{L}$ EPA SMCL drinking-water standard.

The p-values from the Wilcoxon signed-rank tests of statistical significance comparing wells to mine outfalls indicated that many constituents were statistically different between the two populations (table 5). Constituent concentrations that were statistically significantly higher in wells when compared to mine outfalls included barium, bromide, sodium, chloride, hydrogen sulfide, silica, iron, manganese, ammonia, and radon. Constituent concentrations that were statistically significantly higher in mine outfalls when compared to wells included dissolved oxygen, E. coli bacteria, nitrate, sulfate, magnesium, uranium, antimony, and selenium. These trends were expected as the mine outfalls represent highly oxygenated waters whereas the wells typically represent waters with low oxygen content. As a result, these statistical trends indicate that redox processes were active within the aquifers sampled.

The oxidation of sulfide minerals may account for sulfate and selenium concentrations in groundwater and concentrations in the mine outfalls sampled. In the presence of iron, selenium is commonly coprecipitated with pyrite, an iron sulfide mineral, or can be adsorbed by iron oxyhydroxide (Hem, 1992). Under oxidizing conditions, iron oxides may adsorb selenium (Cravotta, 2008; Chapman and others, 2013). Pyrite is a common source of the sulfur that oxidizes to form sulfate and is a source of the iron that oxidizes to form solid iron oxyhydroxide.

For the reduced waters, which are common in deep wells, concentrations of barium, chloride, iron, manganese, and radon were higher in the sampled wells than in the highly oxygenated sampled mine outfalls. Median concentrations of barium, chloride, iron, manganese, and radon were $188.5 \mathrm{mg} / \mathrm{L}, 11.4 \mathrm{mg} / \mathrm{L}, 369.5 \mu \mathrm{g} / \mathrm{L}, 124.5 \mu \mathrm{g} / \mathrm{L}$, and 


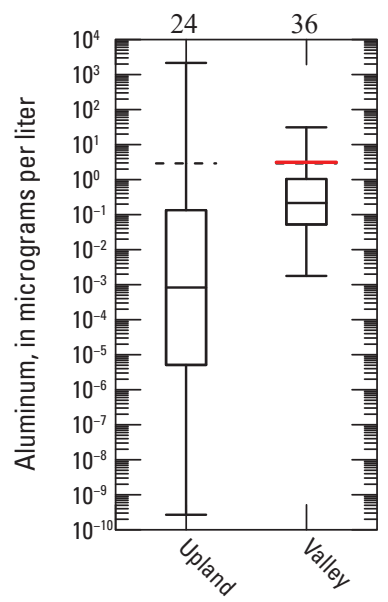

Topographic setting

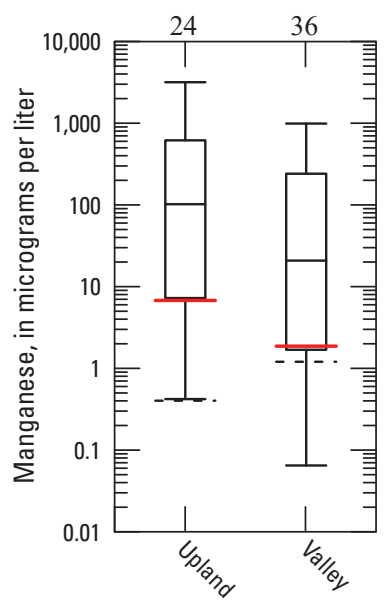

Topographic setting
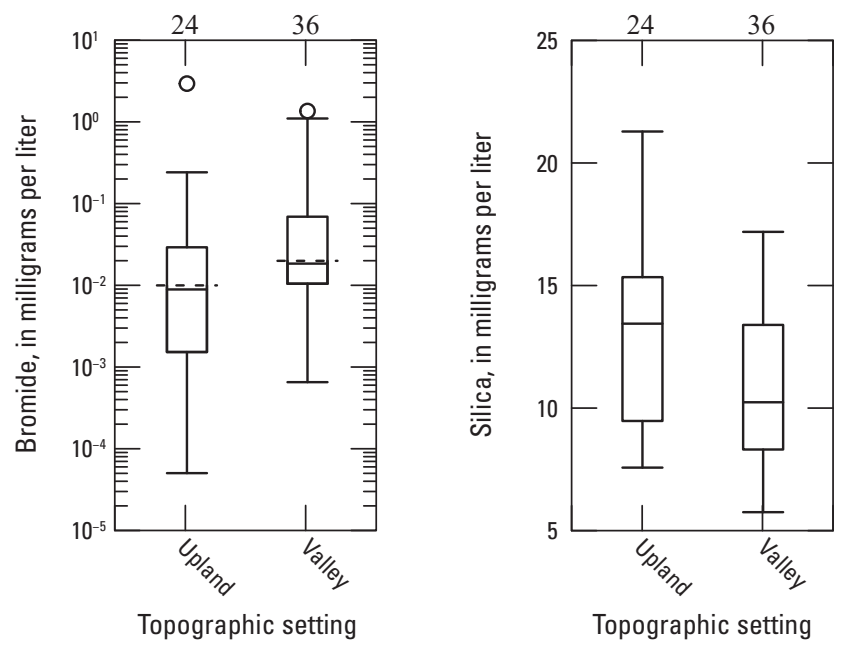

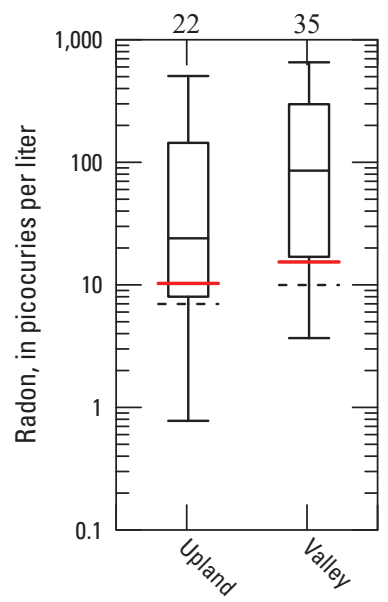

Topographic setting
EXPLANATION

24 Number of values

Largest value within 1.5 times

interquartile range above

75th percentile

75th percentile

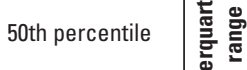

25th percentile - 틀

Imputed value

Detection limit

Smallest value within 1.5 times interquartile range below 25th percentile

O Outlier value-Value is greater than 1.5 times and less than 3 times the interquartile range beyond either end of the box

Figure 12. Constituents related to topographic setting in groundwater samples for 60 sites in the West Virginia southern coal-field province.

$82 \mathrm{pCi} / \mathrm{L}$, respectively, in the samples from the wells; median concentrations of the same constituents were $37.8 \mathrm{mg} / \mathrm{L}$, $1.2 \mathrm{mg} / \mathrm{L}$, less than $4.0 \mu \mathrm{g} / \mathrm{L}$, and less than $0.4 \mu \mathrm{g} / \mathrm{L}$ (both below method detection limits), and $16 \mathrm{pCi} / \mathrm{L}$, respectively, in the samples from the mine outfalls.

The significantly higher concentrations of iron and manganese in the wells sampled are a result of the reduction of iron- and manganese-bearing minerals, and the higher concentrations of barium and chloride are likely associated with comingling of deeper brackish or saline waters with shallow groundwater.

\section{Groundwater Quality in Relation to Well Construction}

As discussed in the previous section, site type and topographic position can influence the chemical composition of the groundwater sampled. The dissolved oxygen content of shallow groundwater, which is typically derived from mine outfalls or from wells less than $100 \mathrm{ft}$ in depth, often is high, so metals such as iron and manganese are commonly not detected in shallow groundwater emerging from outfalls within the study area. For this study, well depths were available for 45 of the 60 wells sampled, however, the outfalls were assigned a depth of $0.00 \mathrm{ft}$ as they emerge at land surface. Unfortunately, the distribution of wells available for sampling typically included older wells, as few new wells have been drilled in the study area in recent years due to declining population. Therefore, information on the lengths of well casing and whether the wells were grouted adequately was not available for this study; the discussion of well construction is based solely on the well depth data.

The correlation matrix developed as part of this study (appendix 1) indicated that well depth had a statistically significant inverse correlation with dissolved oxygen, nitrate, and selenium, and a positive correlation with manganese. Well 
A.
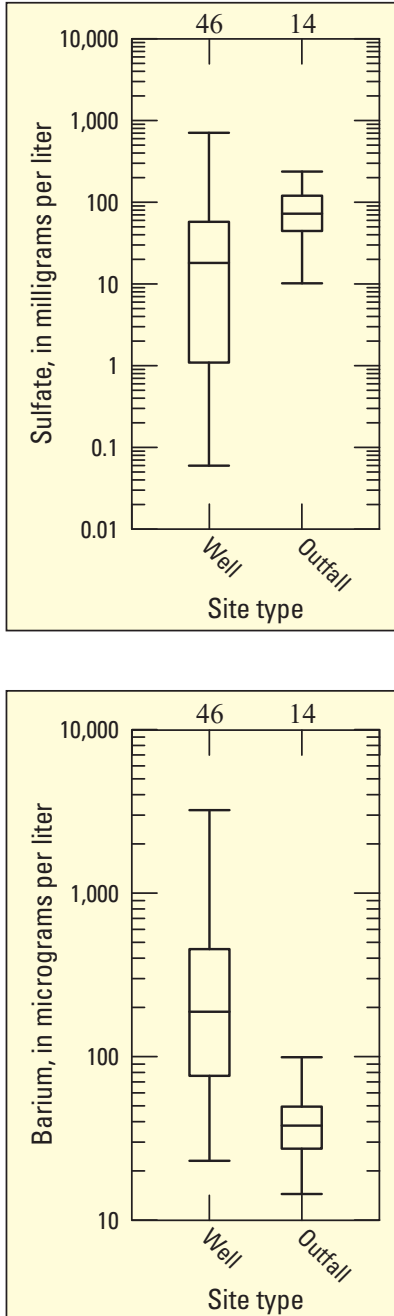

B.

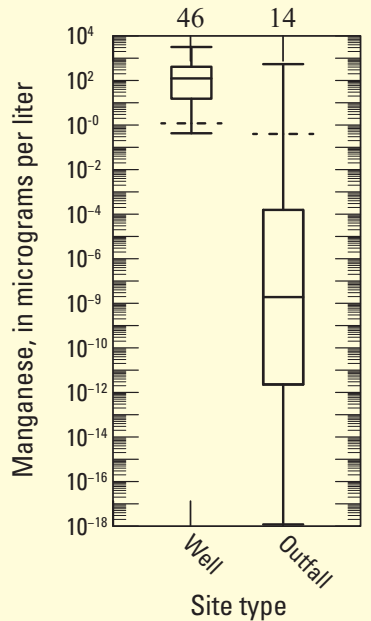

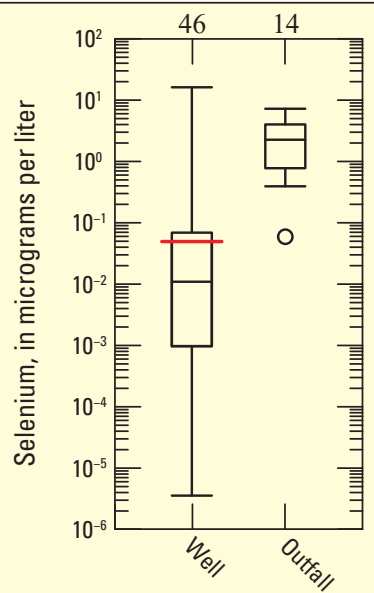

Site type
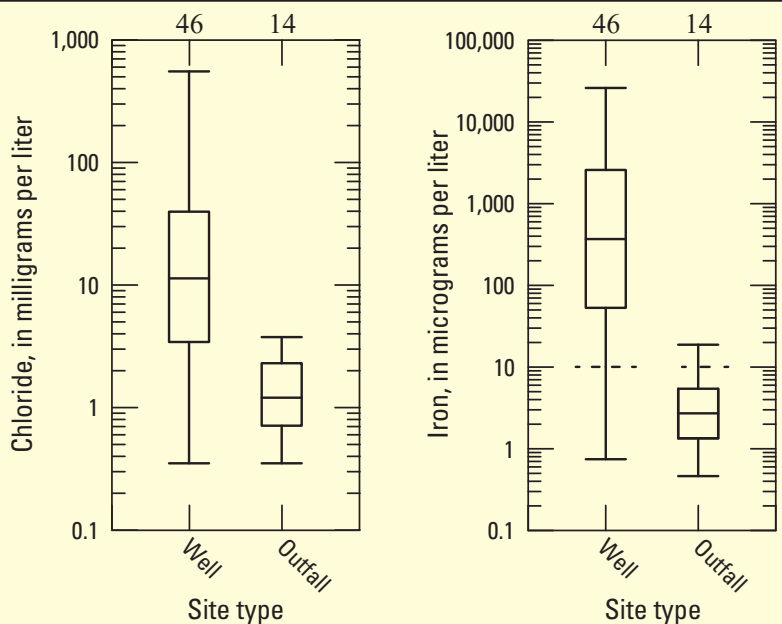

Site type
EXPLANATION

14 Number of values

Largest value within 1.5 times interquartile range above 75th percentile

75th percentile

50th percentile

25th percentile

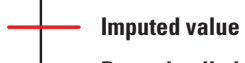

- - - - Detection limit

Smallest value within 1.5 time interquartile range below 25th percentile

O Outlier value - Value is greater than 1.5 times and less than 3 times the interquartile range beyond either end of the box

Figure 13. Distribution of $A$, sulfate and selenium with respect to dissolved oxygen and site type, either mine outfalls or wells, and $B$, barium, chloride, iron, manganese, and radon with respect to site type, either mine outfalls or wells, in groundwater samples for 60 sites in the West Virginia southern coal-field province. 
Table 8A. Statistical summary of analytical results for groundwater samples from the West Virginia southern coal-field province for 14 mine outfalls sampled in the study area.

[ft, feet; NAVD88, North American Vertical Datum of 1988; gal/min, gallons per minute; ${ }^{\circ} \mathrm{C}$, degrees Celsius; $\mathrm{mg} / \mathrm{L}$, milligrams per liter; std, standard; $\mu \mathrm{S} / \mathrm{cm}$, microsiemens per centimeter at $25^{\circ} \mathrm{C}$; NTRU, nephelometric turbidity ratio units; <, less than; nc, all values less than method detection limits therefore mean and median concentrations were not computed; $\mathrm{N}$, nitrogen; $\mathrm{NO}_{3}+\mathrm{NO}_{2}$, nitrate plus nitrite; $\mathrm{P}$, phosphorus; MPN/100 mL, most probable number per 100 milliliters of sample; $\mu \mathrm{g} / \mathrm{L}$, micrograms per liter; $\mathrm{pCi} / \mathrm{L}$, picocuries per liter; $\mathrm{mg} / \mathrm{kg}$, milligrams per kilogram; E, exponential value]

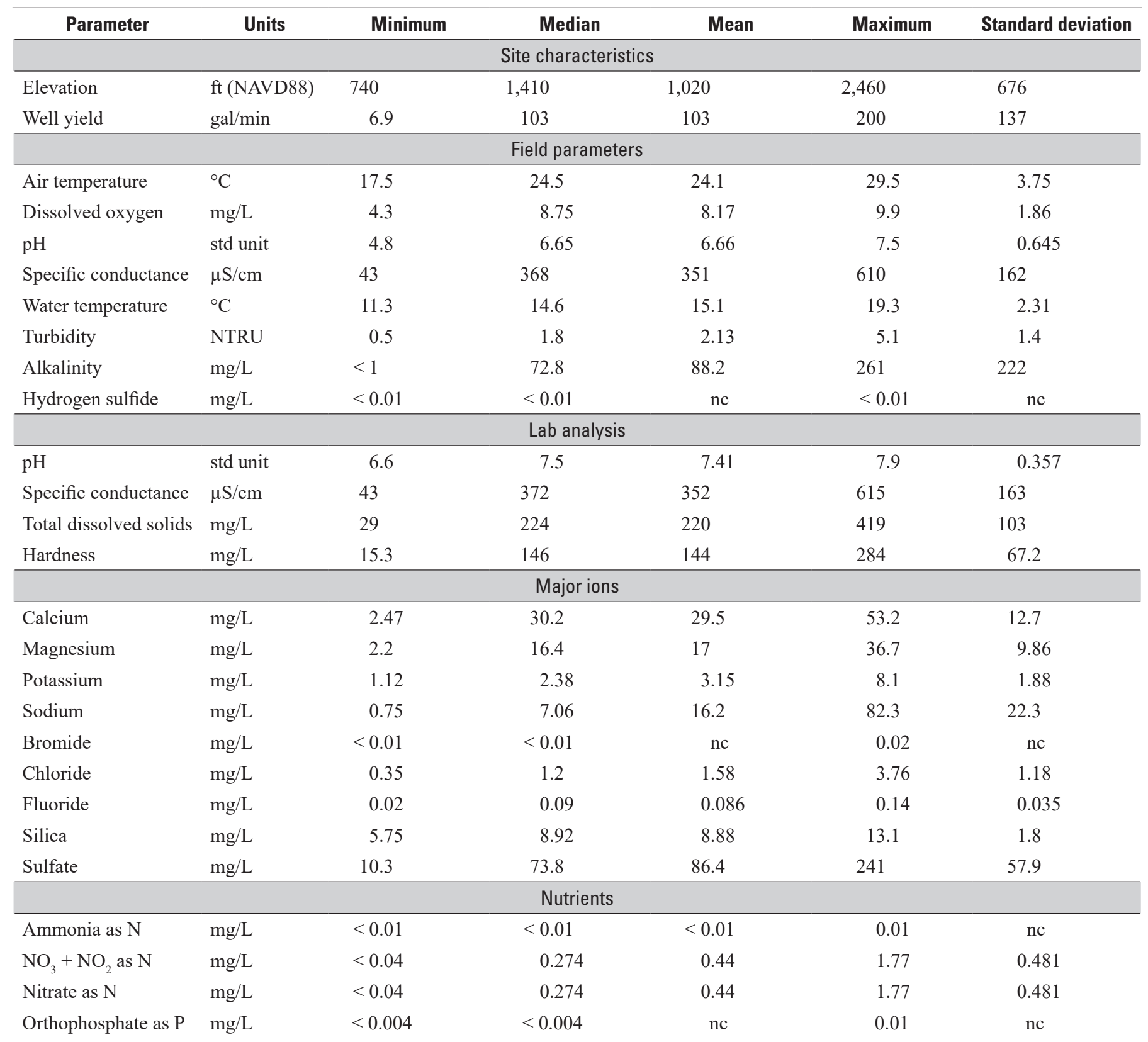


Table 8A. Statistical summary of analytical results for groundwater samples from the West Virginia southern coal-field province for 14 mine outfalls sampled in the study area.-Continued

[ft, feet; NAVD88, North American Vertical Datum of 1988; gal/min, gallons per minute; ${ }^{\circ} \mathrm{C}$, degrees Celsius; $\mathrm{mg} / \mathrm{L}$, milligrams per liter; std, standard; $\mu \mathrm{S} / \mathrm{cm}$, microsiemens per centimeter at $25^{\circ} \mathrm{C}$; NTRU, nephelometric turbidity ratio units; <, less than; nc, all values less than method detection limits therefore mean and median concentrations were not computed; $\mathrm{N}$, nitrogen; $\mathrm{NO}_{3}+\mathrm{NO}_{2}$, nitrate plus nitrite; $\mathrm{P}$, phosphorus; MPN/100 mL, most probable number per 100 milliliters of sample; $\mu \mathrm{g} / \mathrm{L}$, micrograms per liter; $\mathrm{pCi} / \mathrm{L}$, picocuries per liter; $\mathrm{mg} / \mathrm{kg}$, milligrams per kilogram; E, exponential value]

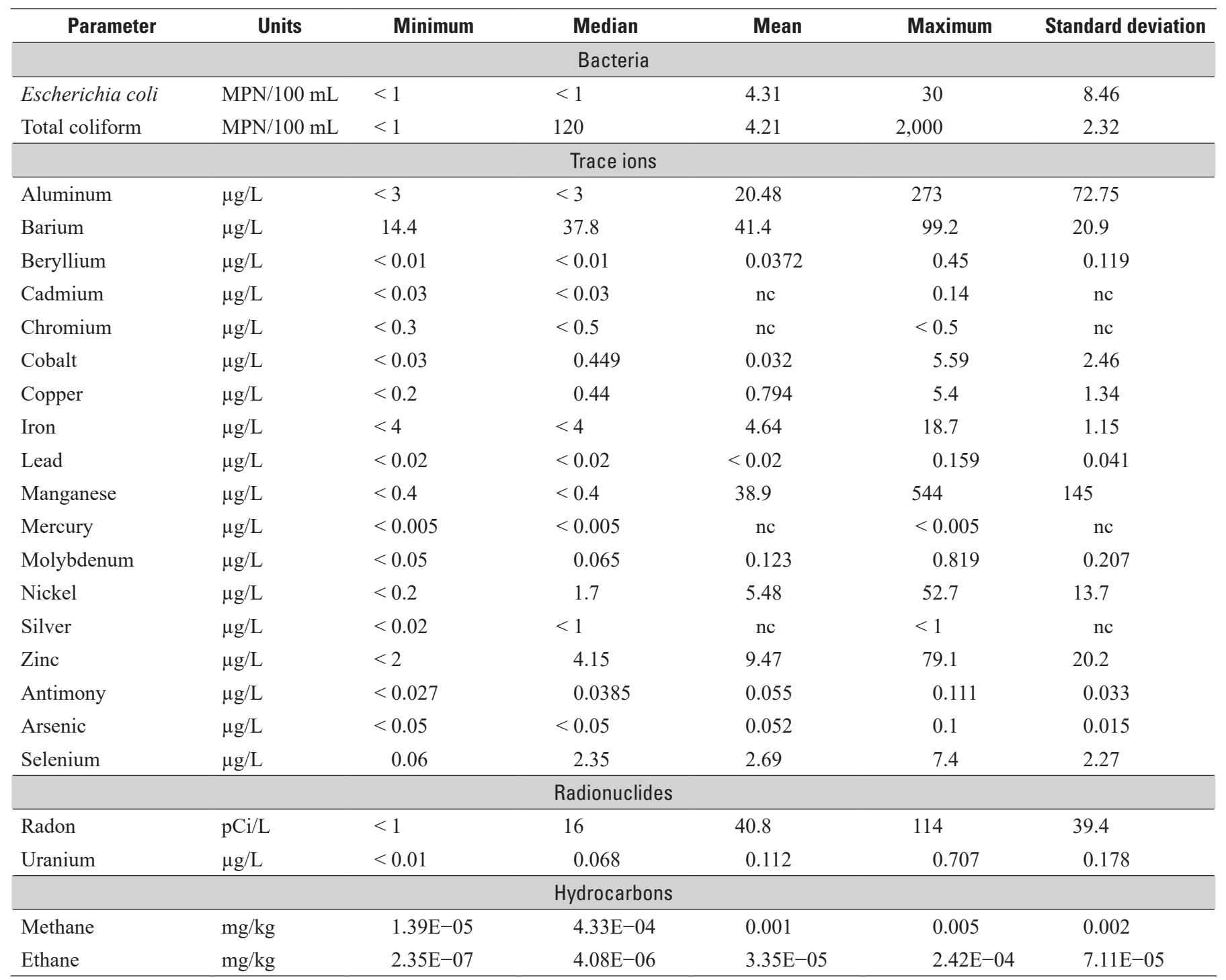


Table 8B. Statistical summary of analytical results for groundwater samples from the West Virginia southern coal-field province for 46 wells sampled in the study area.

[ft, feet; NAVD88, North American Vertical Datum of 1988; bls, below land surface; in., inches; gal/min, gallons per minute; ${ }^{\circ} \mathrm{C}$, degrees Celsius; mg/L, milligrams per liter; std, standard; $\mu \mathrm{S} / \mathrm{cm}$, microsiemens per centimeter at $25^{\circ} \mathrm{C} ; \mathrm{NTRU}$, nephelometric turbidity ratio units; <, less than; $\mathrm{N}$, nitrogen; $\mathrm{NO}_{3}+\mathrm{NO}_{2}$, nitrate plus nitrite; P, phosphorus; MPN/100 mL, most probable number per 100 milliliters of sample; >, greater than; $\mu \mathrm{g} / \mathrm{L}$, micrograms per liter; $\mathrm{pCi} / \mathrm{L}$, picocuries per liter; $\mathrm{mg} / \mathrm{kg}$, milligrams per kilogram; nc, all values less than method detection limits therefore mean and median concentrations were not computed; E, exponential value]

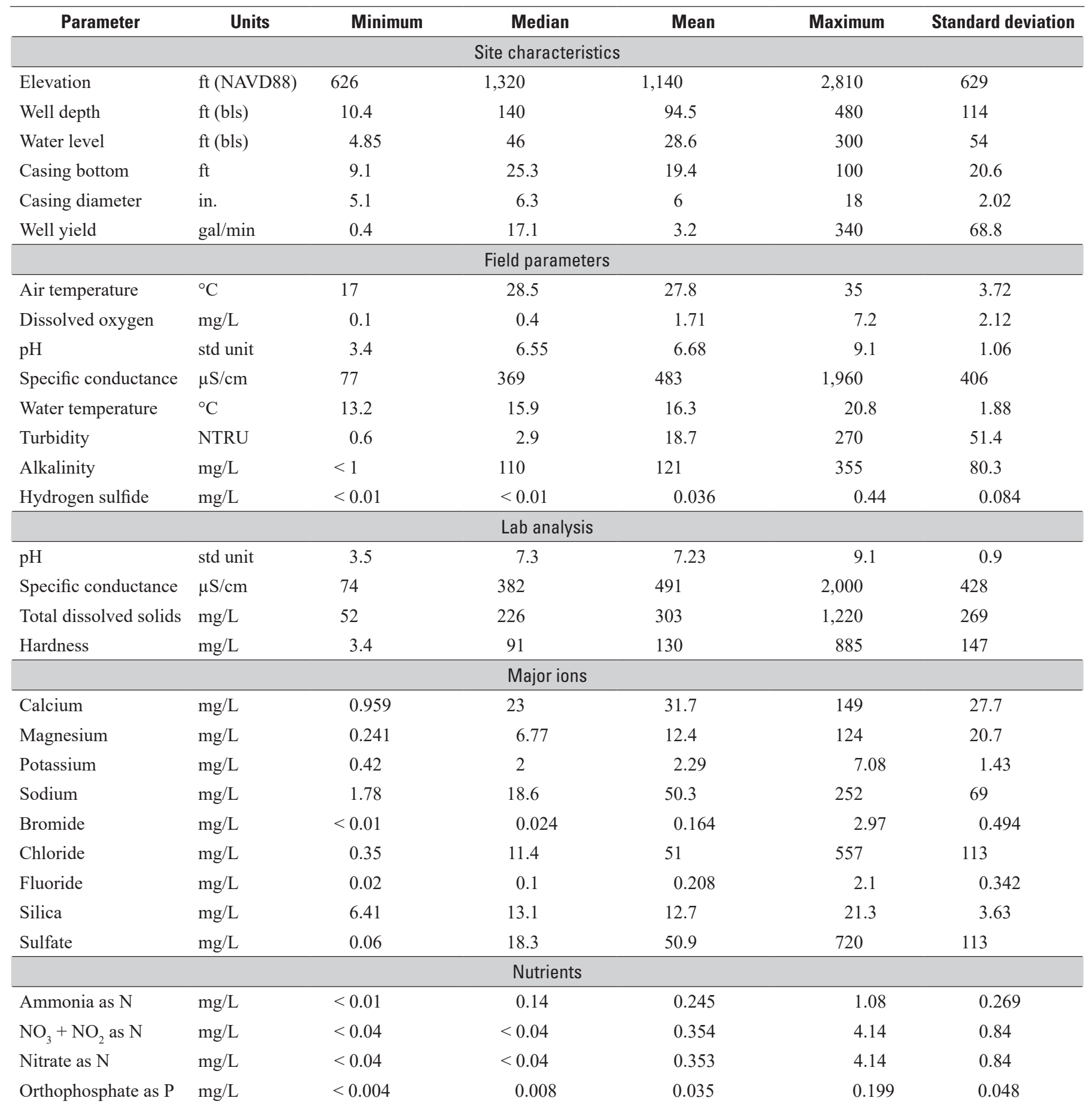


Table 8B. Statistical summary of analytical results for groundwater samples from the West Virginia southern coal-field province for 46 wells sampled in the study area.-Continued

[ft, feet; NAVD88, North American Vertical Datum of 1988; bls, below land surface; in., inches; gal/min, gallons per minute; ${ }^{\circ} \mathrm{C}$, degrees Celsius; mg/L, milligrams per liter; std, standard; $\mu \mathrm{S} / \mathrm{cm}$, microsiemens per centimeter at $25^{\circ} \mathrm{C} ; \mathrm{NTRU}$, nephelometric turbidity ratio units; <, less than; $\mathrm{N}$, nitrogen; $\mathrm{NO}_{3}+\mathrm{NO}_{2}$, nitrate plus nitrite; P, phosphorus; MPN/100 mL, most probable number per 100 milliliters of sample; >, greater than; $\mu \mathrm{g} / \mathrm{L}$, micrograms per liter; $\mathrm{pCi} / \mathrm{L}$, picocuries per liter; $\mathrm{mg} / \mathrm{kg}$, milligrams per kilogram; $\mathrm{nc}$, all values less than method detection limits therefore mean and median concentrations were not computed; $\mathrm{E}$, exponential value]

\begin{tabular}{|c|c|c|c|c|c|c|}
\hline Parameter & Units & Minimum & Median & Mean & Maximum & Standard deviation \\
\hline \multicolumn{7}{|c|}{ Bacteria } \\
\hline Escherichia coli & MPN/100 mL & $<1$ & $<1$ & 3.06 & 99 & 14.6 \\
\hline \multicolumn{7}{|c|}{ Trace ions } \\
\hline Aluminum & $\mu \mathrm{g} / \mathrm{L}$ & $<3$ & $<3$ & 49.95 & 2,240 & 330.1 \\
\hline Beryllium & $\mu \mathrm{g} / \mathrm{L}$ & $<0.01$ & $<0.01$ & 0.012 & 4.26 & 0.626 \\
\hline Cadmium & $\mu \mathrm{g} / \mathrm{L}$ & $<0.03$ & $<0.03$ & 0.016 & 0.4 & 0.070 \\
\hline Chromium & $\mu \mathrm{g} / \mathrm{L}$ & $<0.3$ & $<0.5$ & $\mathrm{nc}$ & $<1.5$ & $\mathrm{nc}$ \\
\hline Cobalt & $\mu \mathrm{g} / \mathrm{L}$ & $<0.03$ & 0.056 & 2.89 & 93.5 & 14 \\
\hline Copper & $\mu \mathrm{g} / \mathrm{L}$ & $<0.2$ & $<0.2$ & 5.21 & 67.7 & 11.9 \\
\hline Mercury & $\mu \mathrm{g} / \mathrm{L}$ & $<0.005$ & $<0.005$ & $\mathrm{nc}$ & 0.005 & $\mathrm{nc}$ \\
\hline Molybdenum & $\mu \mathrm{g} / \mathrm{L}$ & $<0.05$ & 0.103 & 0.153 & 0.96 & 0.168 \\
\hline Nickel & $\mu \mathrm{g} / \mathrm{L}$ & $<0.2$ & 0.58 & 4.38 & 107 & 16.2 \\
\hline Silver & $\mu \mathrm{g} / \mathrm{L}$ & $<0.02$ & $<0.02$ & 0.014 & $<3$ & 0.012 \\
\hline Zinc & $\mu \mathrm{g} / \mathrm{L}$ & $<2$ & 6.7 & 19.6 & 242 & 41.5 \\
\hline Antimony & $\mu \mathrm{g} / \mathrm{L}$ & $<0.027$ & 0.027 & 0.027 & 0.287 & 0.043 \\
\hline Arsenic & $\mu \mathrm{g} / \mathrm{L}$ & $<0.05$ & 0.11 & 0.726 & 6 & 4.93 \\
\hline Selenium & $\mu \mathrm{g} / \mathrm{L}$ & $<0.05$ & $<0.05$ & 0.807 & 16.6 & 2.8 \\
\hline
\end{tabular}


depth has a few of the same correlations as those indicated for redox processes, but the trends are not as strong statistically. Only 10 of 46 wells in this study had depths greater than or equal to $200 \mathrm{ft}$; median and mean well depths were 140 and $94.5 \mathrm{ft}$, respectively. The overall narrow range and average shallow depths of the wells sampled were not sufficient to allow a full statistical assessment of the effect of well depth on overall water quality.

In the study area, many households have septic systems and small gardens; agriculture is uncommon. Nitrate also may be transported to groundwater by leakage from streams, where surface water contaminated by nitrate from improper sewage disposal, which is common in the study area, crosses over active or abandoned underground mine workings. There is also abundant wildlife, ranging from small animals to deer and black bear. An additional potential source of nitrate and ammonia, in reduced form, is from an ANFO mixture, which is a common explosive used in the surface mining of coal. Atmospheric deposition is another potential minor source of nitrate in groundwater. The source of the nitrate detected in this study is not known. However, because of the large number of sites sampled containing either total coliform bacteria (65 percent of sites sampled tested positive for total coliform) or E. coli bacteria (23.3 percent of sites sampled contained E. coli bacteria), the correlation between shallow well depths and increasing dissolved oxygen and nitrate may indicate potential contamination by either residential septic systems, fecal material deposited by animals, or potential interaction of groundwater with nearby streams contaminated by fecal bacteria from inadequate sewage collection and treatment systems in the study area. The positive correlation between well depth and manganese and the negative correlation with dissolved oxygen is likely caused by more reducing conditions and limited atmospheric exchange with water in the deeper wells.

\section{Dissolved Hydrocarbons}

The origin of abundant methane and other dissolved hydrocarbons in groundwater in southern West Virginia's coalfield region has long been a subject of debate. An assessment of the role shallow coal beds and deeper thermogenic gases play is necessary. Dissolved hydrocarbon data collected for this study provide information with respect to the potential presence of methane and other dissolved hydrocarbons in relatively shallow groundwater in the southern West Virginia coal-field province. The dissolved hydrocarbon data collected for this study are publicly available in the USGS ScienceBase repository (Haase and others, 2018). The data were published as a data release summarizing data for several concurrent USGS studies to document dissolved hydrocarbon occurrence and distribution for various aquifers within the midwestern and northeastern parts of the United States. The data are presented in units of milligram per kilogram $(\mathrm{mg} / \mathrm{kg})$ which is equivalent to milligrams per liter $(\mathrm{mg} / \mathrm{L})$ at the temperature, pressure, and density of groundwater sampled for the study.

\section{Methane}

Dissolved methane is ubiquitous in groundwater and has been extensively studied by the USGS and others in West Virginia (Mathes and White, 2006; White and Mathes, 2006; Kozar and others, 2012; Chambers and others, 2015; Harkness and others, 2017; McAdoo and Kozar, 2017). The primary concern regarding the presence of methane in groundwater is the potential for the accumulation of flammable concentrations in enclosed spaces (homes, outbuildings, well casings), with secondary concerns arising from the qualitative characteristics of water (ebullition and clarity) and for its potential for co-occurrence with other contaminants that can negatively impact the safety and utility of the water. Although there are no regulatory action levels for methane in groundwater, the OSMRE recommends a concentration of greater than $10 \mathrm{mg} / \mathrm{L}$ as a LOC warranting investigation, and a concentration greater than $28 \mathrm{mg} / \mathrm{L}$ as an IAL at which mitigation strategies should be implemented (Eltschlager and others, 2001). In this study, 2 of the 59 samples collected for dissolved hydrocarbons, Mcd-0214 (greater than $40 \mathrm{mg} / \mathrm{kg}$, above the upper limit of quantification) and Fay-0281 (13.6 mg/kg), exceeded OSMRE recommended levels, and the most probable decadal concentration brackets were $1-10 \mathrm{mg} / \mathrm{kg}$ (12 samples, 20 percent) and 0.0001 to $0.001 \mathrm{mg} / \mathrm{kg}$ (18 samples, 31 percent) (fig. 14).

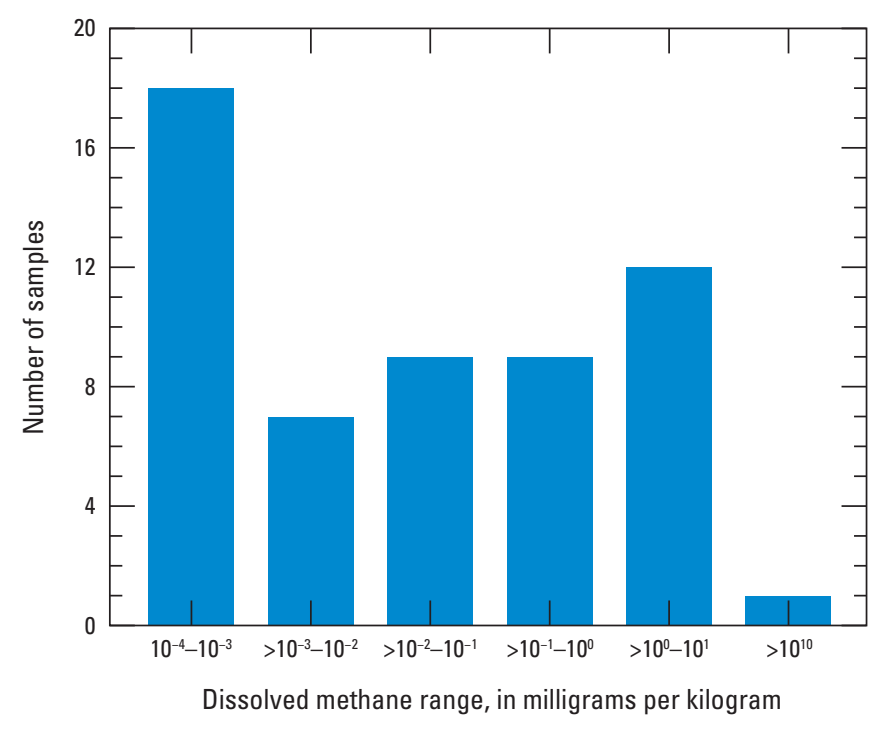

Figure 14. Decadal histogram of dissolved methane concentrations in groundwater samples from the West Virginia southern coal-field province. [>, greater than] 


\section{Ethane and Other Hydrocarbons}

Like methane, dissolved concentrations of ethane, ethene, ethyne, propane, propene, propyne, butanes, and butenes do not have regulatory action levels, but high concentrations warrant investigation and mitigation to prevent accidental combustion (Eltschlager and others, 2001). Pentanes and hexane similarly do not have action levels but have lower volatility and are listed as compounds of concern in EPA's Regional Screen at micrograms per liter levels (U.S. Environmental Protection Agency, 2019a). Benzene has an MCL of $0.005 \mathrm{mg} / \mathrm{L}$, with a MCLG of zero $(0.000) \mathrm{mg} / \mathrm{L}$. All the analyses reported here are on the order of $1 / 10,000$ th of the benzene MCL and are at trace levels that reflect the intent of the EPA MCLG (U.S. Environmental Protection Agency, 2019a). These benzene measurements are considerably lower than levels found in water in equilibrium with air (less than or equal to $10^{-5} \mathrm{mg} / \mathrm{kg}$ ), and could reflect residual levels from well, formation materials, or gases adsorbed to the sampling system.

\section{Dissolved Hydrocarbon Composition and Origin}

Dissolved hydrocarbons in groundwater are broadly characterized as either originating from biogenic bacterial activity or from thermogenic crustal sources. Biogenic gas can be generated in situ in anoxic systems, or have exogenous sources from brines, landfills, shale, and coalbeds (Schoell 1988; Colosimo and others, 2016). Thermogenic hydrocarbons originate from the breakdown of organic compounds at high temperatures and pressures and can enter the groundwater either through some combination of chemical weathering of the host rock, transport upgradient of a fault from a reservoir, coalbeds, along well cases that cross confining layers, and (or) leaks from petroleum production wells and pipes. Biogenic sources of hydrocarbons have relatively high proportions of methane $\left(\mathrm{C}_{1}\right)$ relative to the higher chain hydrocarbons $\left(\mathrm{C}_{2}\right.$ to $\mathrm{C}_{6}$ ) (usually by a factor of 1,000 or more), and are isotopically light, whereas thermogenically produced hydrocarbons have a low proportion of methane compared to other hydrocarbons, and tend to be isotopically heavy (Schoell, 1983; Taylor and others, 2000). The chemical and isotopic composition of thermogenic gas itself is a function of thermal maturity of the originating formation, as well as any transport (fractionation) processes that the hydrocarbons have experienced, with ratios of methane to total hydrocarbons ranging from 100 to 1,000 for gases of increasing thermal maturity (Schoell, 1983; Whiticar, 1999). Thermogenic gases also have other chemical characteristics that are unique to their formation and transport history, including low concentrations of light alkenes and alkynes, the presence of higher alkanes in sequentially decreasing concentrations in a characteristic cracking pattern, and distinct ratios of structural isomers such as iso- and $n$-pentane and iso- and $n$-butane.

The relation between methane concentration and the ratio of methane $\left(\mathrm{C}_{1}\right)$ to ethane $\left(\mathrm{C}_{2}\right)$ can be an indicator of the source of dissolved hydrocarbon gases in water. In groundwater, where biogenic sources are the dominant contributor to dissolved methane, the ratio of methane/ethane increases with methane concentration, as any weak in situ thermogenic sources are diluted. In groundwater where there are thermogenic sources of gas, the ratio of methane to ethane does not change as much, resting on a mixing line between the biogenic emission ratio and the ratio in the composite hydrocarbon gas source (Molofsky and others, 2013). However, microbial oxidation of natural gas also can result in higher methane to ethane ratios, and so, additional indicators are needed to assess the source of these gases in water (Whiticar, 1999; Révész and others, 2010).

The relation of methane/ethane to methane is shown in figure 15. The black lines in the graph indicate hypothetical addition of biogenic gas at a 1,000:1 and 10,000:1 methane/ethane ratios into groundwater with low background methane and ethane concentrations. The green line at the bottom right of the graph represents the detection limit of the method. Using the relation of methane/ethane compared to methane (fig. 15), most samples reflect a biogenic gas production into water with a low-methane $\left(<10^{-3} \mathrm{mg} / \mathrm{kg}\right)$ and low-hydrocarbon background (methane/ethane ratio of 17 to $1,000)$. The sample results show methane/ethane ratios that increase rapidly with methane concentration. Many samples lie in or near a region defined by biogenic gas additively mixing into a low-methane and low-ethane background.

Additionally, there is an enrichment gradient from the low methane and high methane/ethane samples to high methane and low methane/ethane samples with the increased abundance of branched alkanes (isobutane $/ n$-butane greater than 1 and isopentane $/ n$-pentane greater than 2.5) relative to the straight chain isomers (figs. 16 and 17). There is little information available about the root cause of the isobutane $/ n$-butane and isopentane $/ n$-pentane ratios in biogenic natural gas sources, but these have been useful for source apportionment in air quality studies and for understanding the source and geochemistry of thermogenic gases. As natural gas is transported and modified by biogenic activity, the ratio of branched to straight chain isomers $(i-/ n-)$ increases. Here, the unmodified gases (high methane, high methane/ ethane) have isobutane $/ n$-butane ratios of approximately 0.3 and isopentane $/ n$-pentane ratios of approximately 0.6 , whereas the most modified (high methane, low methane/ethane) have an isobutane $/ n$-butane ratio on the order of approximately 3 , and isopentane $/ n$-pentane ratios of approximately 3 . These gradients are another indicator that the gas in these samples is 
of biogenic origin and has undergone subsequent microbial modification and oxidation processes (Prinzhofer and others, 2000; Igari and others, 2007).

Further evidence of biogeochemical processing is shown in figure 18. In this figure, the ratio of ethane to propane is plotted against the ratio of methane to ethane. Unmodified thermogenic gas typically has a methane to ethane ratio in the range of 50 to 100 (dark purple band), with examples of very dry gases of high thermal maturity reaching nearly 1,000 (light purple band). An unmodified thermogenic gas will have a propane/ethane ratio in the range of 2-5 (green band). In this study, no samples fell into the intersection of methane/ethane and ethane/propane ratios that reflect an unmodified thermogenic source, indicating post production processing of all samples, including those with high methane concentrations and low methane to ethane ratios.
These signatures may arise as biogenic gas in groundwater transitions between methanotrophic (hydrocarbon-oxidizing) and methanogenic (methane-producing) regimes, which preferentially consume methane (fig. 18) (Schoell, 1983, 1988; Whiticar, 1999). Many of the high (greater than $1 \mathrm{mg} / \mathrm{kg}$ ) methane samples have chlorine to bromine mass ratios in the range of 0-500 (fig. 19), and they are characterized by low nitrate and sulfate levels. These samples are characteristic of valley bottom samples and the presence of Appalachian Basin brines into the surficial aquifer that either could carry (meaning they are the source of the gas) or co-occur (meaning they are governed by separate processes that result in coincidental observations) with biogenic gas (Heisig and Scott, 2013; Llewellyn and others, 2015; Colosimo and others, 2016; Molofsky and others, 2016; Yan and others, 2017, Harkness and others, 2017).

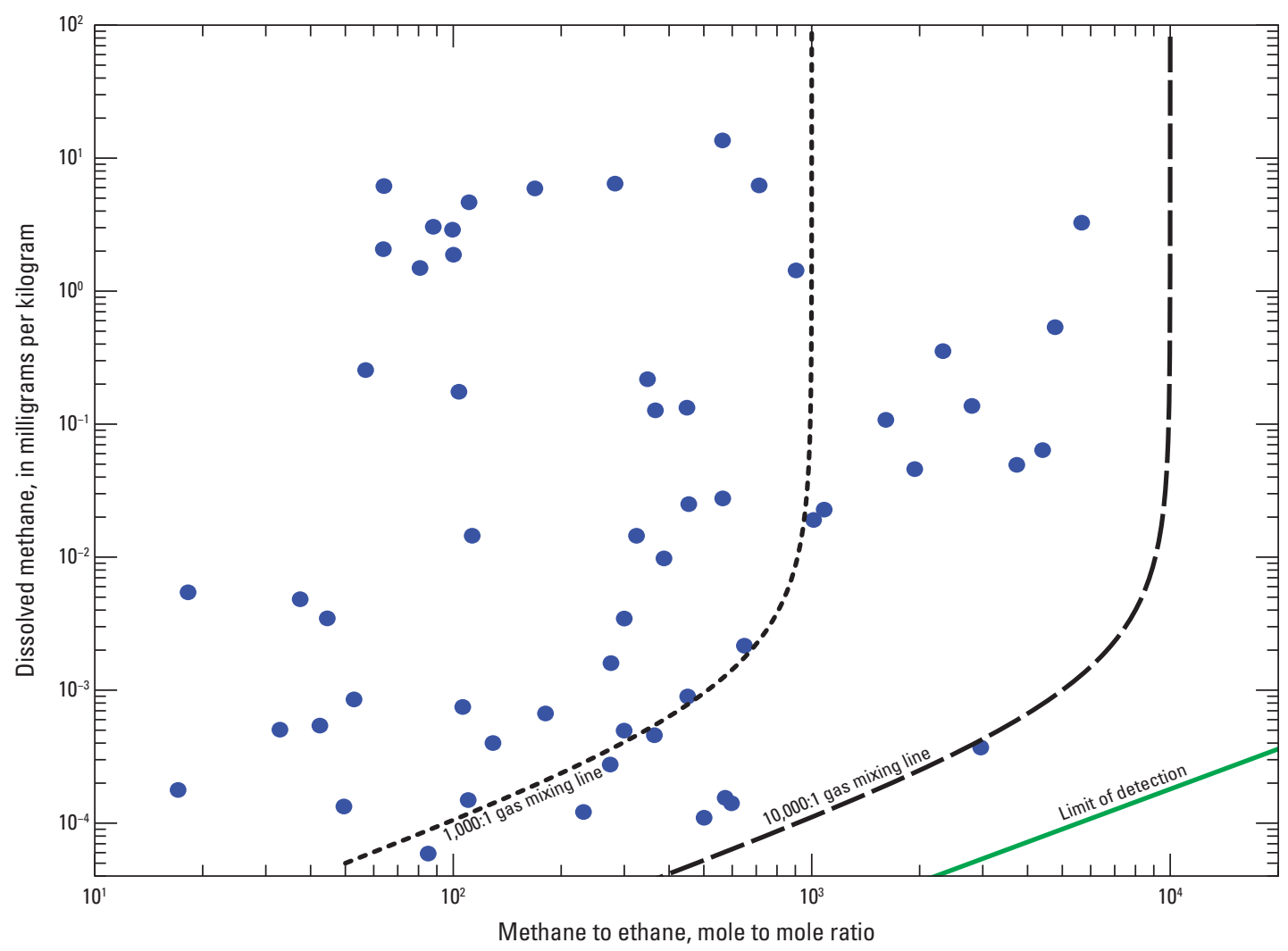

Figure 15. Relation between methane concentration and the methane/ethane ratio in groundwater samples from the West Virginia southern coal-field province. 


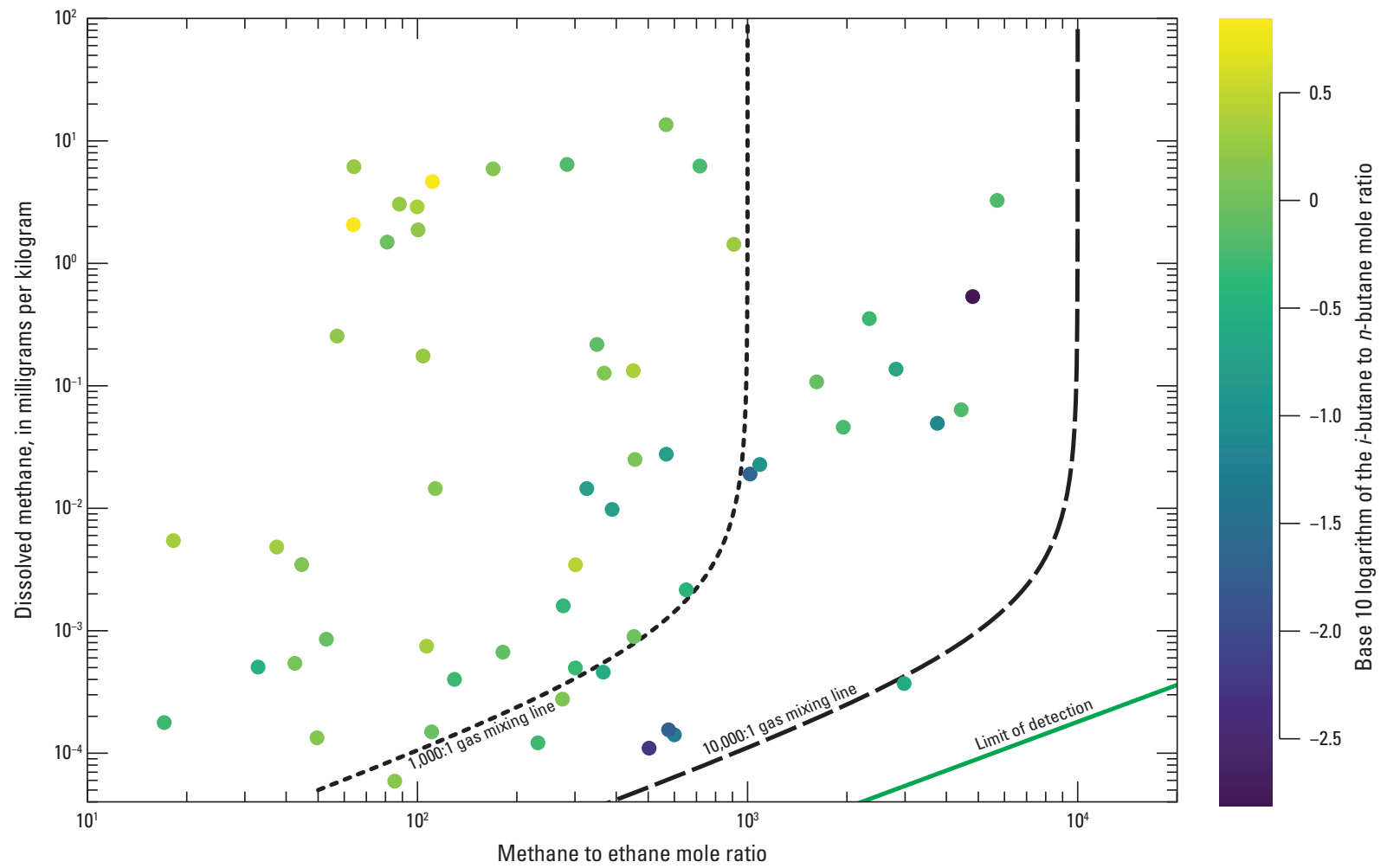

Figure 16. Dissolved methane concentration and the methane/ethane ratio, with a color scale of the enrichment gradient of isobutane over $n$-butane for samples with high methane and low ethane/methane ratio.

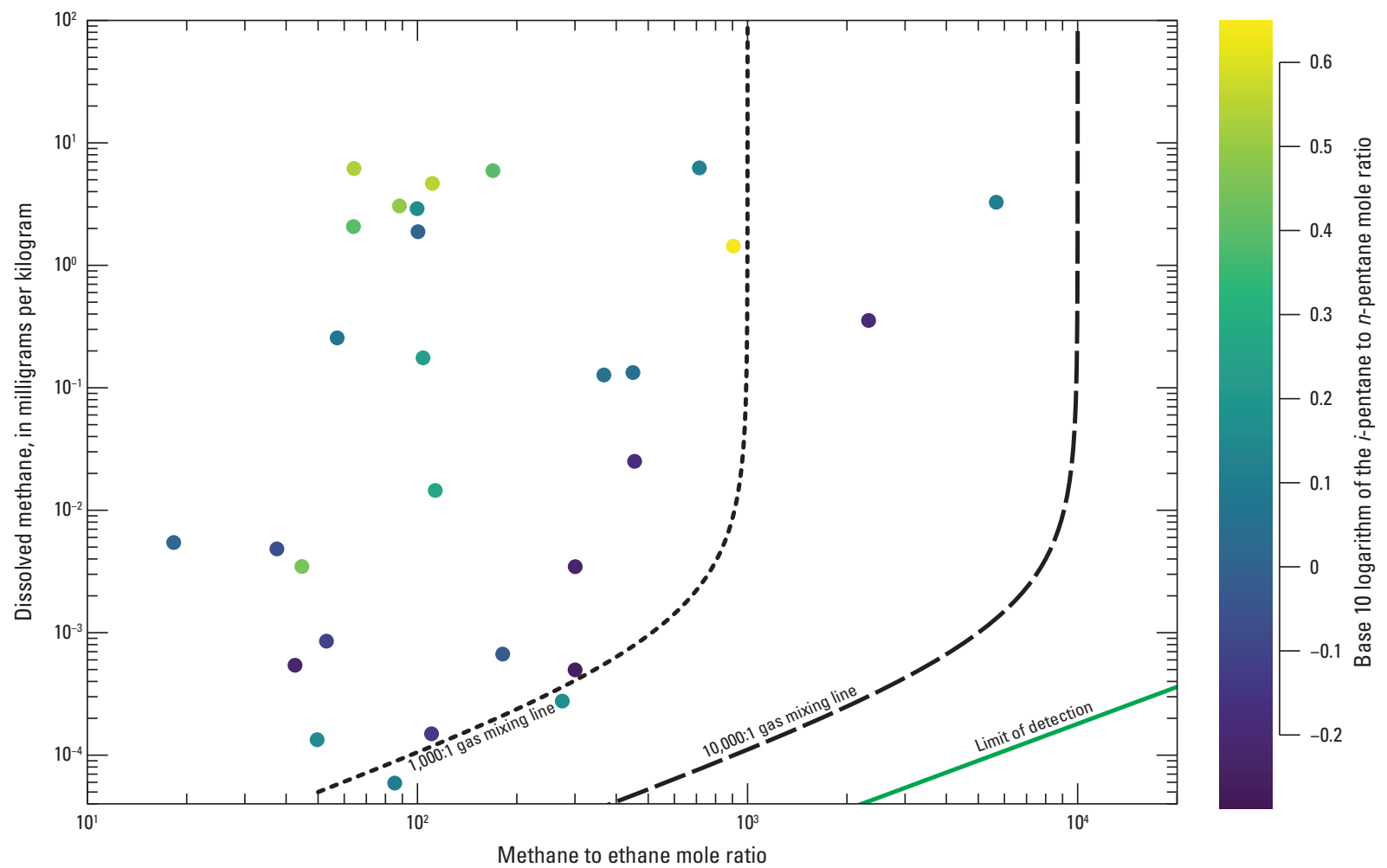

Figure 17. Dissolved methane concentration and the methane/ethane ratio, with a color scale of the enrichment gradient of isopentane over $n$-pentane for samples with high methane and low ethane/methane ratio. 


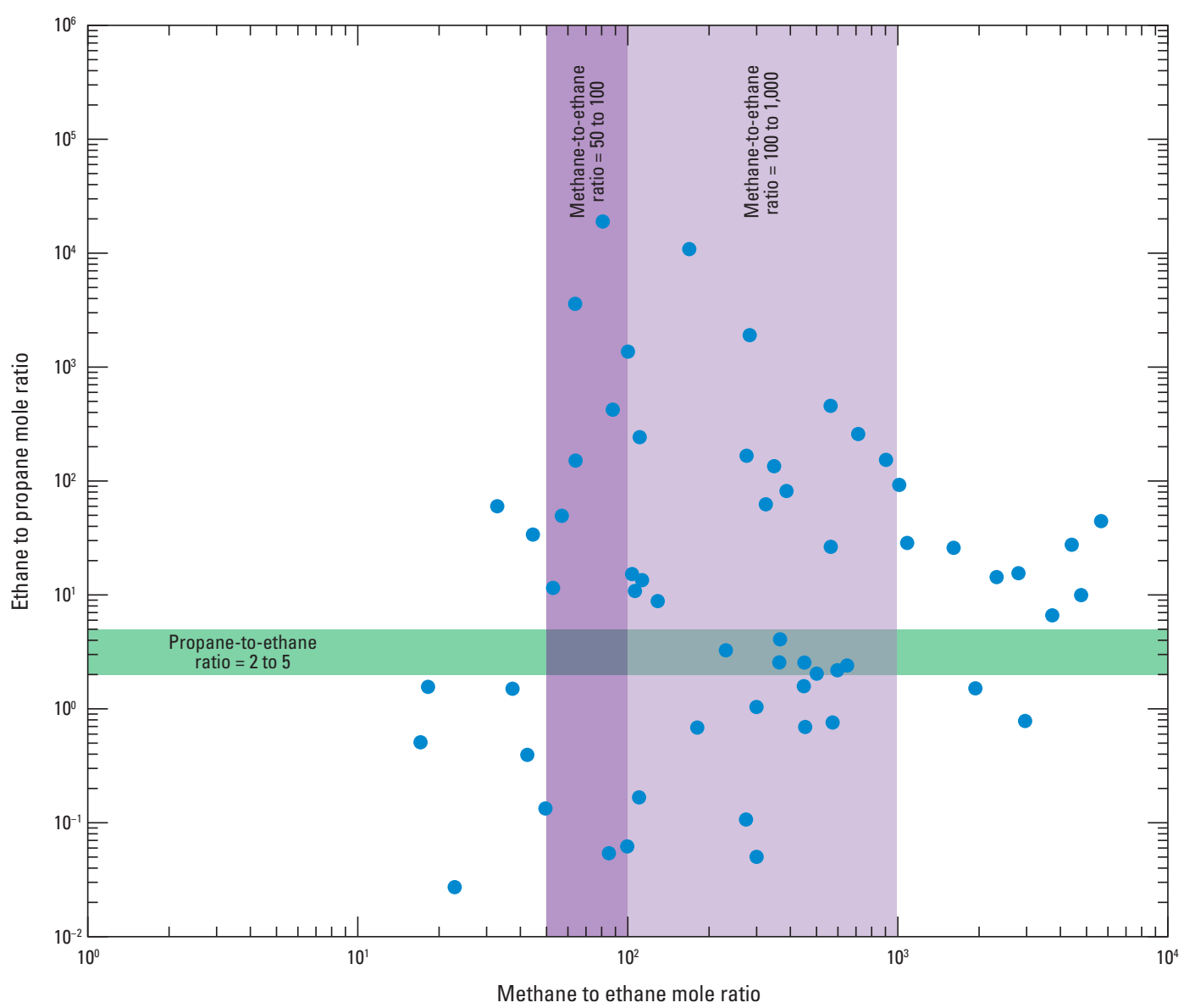

Figure 18. Ratios of methane/ethane and ethane/propane in natural gas indicative of origin and processes that have acted on the sample.

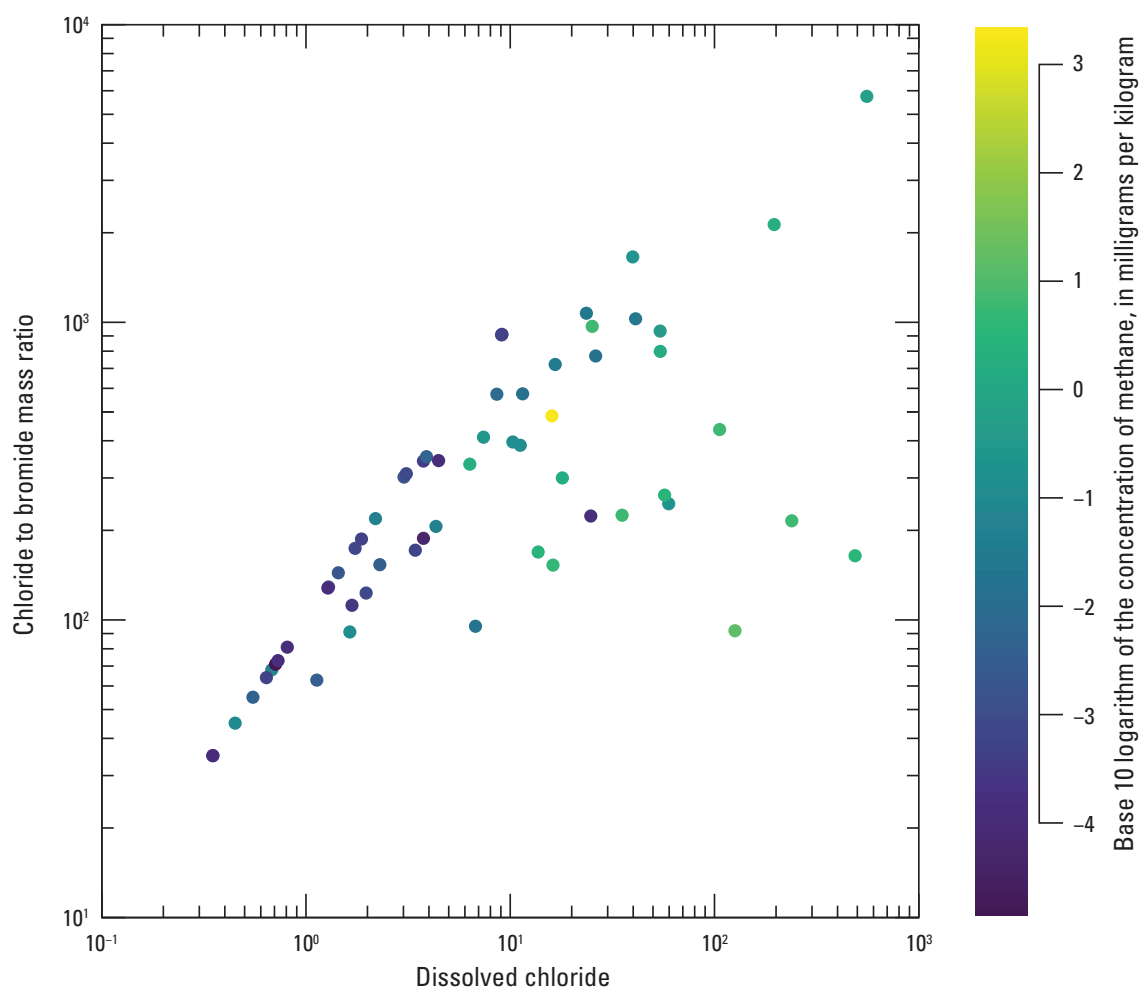

Figure 19. Methane concentration versus chloride to bromide mass ratio and chloride concentration. 


\section{Geochemistry}

Geochemistry was evaluated by multivariate statistical analysis of the available chemical data for the 60 sites sampled using PCA, comparing significant Spearman correlation coefficients, and by computation of SIs for mineral species. PCA is a multivariate statistical analysis method that allows rapid analysis of large datasets and extracts the eigenvectors and eigenvalues from a variance covariance matrix. PCA can be used to understand the intercorrelations of many variables and provide insight into the underlying hydrochemical processes (Davis, 1986). The results of the PCA model (table 9) show five major hydrogeologic variables controlling the system. In this study, PCA indicated that 58 percent of the total variance in the dataset could be explained by the first three principal components, and an additional 22 percent of the variance in the dataset could be explained by principal components four (16 percent) and five ( 6 percent). Spearman rho correlation coefficients were found to be significant $(\mathrm{p}<0.001)$ in this study for values greater than 0.41 and less than -0.41 (appendix 1; table 9).

\section{Mineral Controls on Solute Concentrations}

Mineral phases present within the bedrock and soil zones near a sample site are important in controlling solute concentrations in groundwater. Various sulfate, sulfide, carbonate, oxide, and aluminosilicate minerals have been identified in the bedrock of southern West Virginia and were used to calculate SIs even though the presence of these minerals can vary spatially with depositional environment. If a mineral is present in a sample, the SI indicates the potential of that mineral to precipitate or dissolve in solution. SIs were computed using the USGS geochemical model, PHREEQC (Parkhurst and Appelo, 2013), and plotted against pH (fig. 20) to identify mineral phases that may affect the solute concentrations if the mineral is present.

Carbonate minerals in the study area provide an important source of alkalinity that buffers acid-producing sulfide oxidation reactions and are associated with limestone units and clastic rocks that contain calcareous cement. Calcite $\left(\mathrm{CaCO}_{3}\right)$ and dolomite $\left(\mathrm{CaMg}\left[\mathrm{CO}_{3}\right]\right)$ are two major constituents of limestone, are generally dissolved at low $\mathrm{pH}$, and are an important source of calcium and magnesium in the system. Calcite and dolomite are undersaturated at low $\mathrm{pH}$, eventually come into equilibrium at $\mathrm{pH}$ greater than 7.5 , and may precipitate at $\mathrm{pH}$ greater than 9 (fig. 20). Other important carbonate minerals include siderite $\left(\mathrm{FeCO}_{3}\right)$, rhodochrosite $\left(\mathrm{MnCO}_{3}\right)$, and witherite $\left(\mathrm{BaCO}_{3}\right)$ because of their possible control on the presence of iron, manganese, and barium in solution. These three elements have a significant inverse correlation with dissolved oxygen (appendix 1; table 9) and are highly dependent on redox as well as dissolved carbonate. Siderite is undersaturated in this groundwater system and may dissolve, which means it may be an important source of iron.
Another source of iron comes from the dissolution of sulfide minerals that also produce dissolved sulfate. Sulfate concentrations can decrease through physical dilution and chemical reduction of sulfate to hydrogen sulfide, or precipitation of sulfate minerals such as barite. Although those processes can decrease sulfate concentrations, sulfate is still much higher than iron in the study area, which means that the precipitation of ferric oxyhydroxides or siderite may be acting as a sink for iron in southern West Virginia. Barium has a significant inverse correlation with low dissolved oxygen (appendix 1; table 9) and the SI for barite ranged from undersaturated to supersaturated (fig. 20). The inverse correlation between barium and dissolved oxygen indicates that barium may be released to solution by the reductive dissolution of barite. Sulfide mineral dissolution and the subsequent oxidation to sulfate occurs in more oxic settings (shallow aquifers), whereas in environments where there is low dissolved oxygen (deeper aquifers), sulfate reduction can be an important process to remove sulfate from solution (Ouyang and others, 2017; Renock and others, 2016). Sulfide mineral dissolution and the subsequent formation of sulfate occurs in more oxic settings (shallow aquifers), and in environments where there is low dissolved oxygen (deeper aquifers), sulfate reduction can be an important process to remove sulfate from solution. These processes can effectively increase the possibility of barite precipitation in oxic aquifers that have high sulfate concentrations and decrease precipitation of barium in anoxic aquifers experiencing sulfate reduction.

Other factors that may affect major and trace constituents include exchange reactions, adsorption, and dissolution of aluminosilicate minerals. Chlorite $\left.\left(\mathrm{Mg}_{5} \mathrm{Al}_{2} \mathrm{Si}_{3} \mathrm{O}_{10}[\mathrm{OH}]\right)_{8}\right)$ and feldspars such as albite $\left(\mathrm{NaAlSi}_{3} \mathrm{O}_{8}\right)$ are both undersaturated for the range of $\mathrm{pH}$ (fig. 20) and would be expected to dissolve in the study area, which would release aluminum and silica. Incongruent dissolution of unstable aluminosilicates likely results in the secondary solid phases of kaolinite $\left(\mathrm{Al}_{2} \mathrm{Si}_{2} \mathrm{O}_{5}[\mathrm{OH}]_{4}\right)$ and quartz $\left(\mathrm{SiO}_{2}\right)$. These two minerals are supersaturated under most of the $\mathrm{pH}$ range (fig. 20) and identified in the petrographic analysis of the Elkhorn study (Kozar and others, 2012). Illite $\left(\mathrm{K}_{0.6} \mathrm{Mg}_{0.25} \mathrm{Al}_{2.3} \mathrm{Si}_{3.5} \mathrm{O}_{10}[\mathrm{OH}]_{2}\right)$ was undersaturated below a $\mathrm{pH}$ of 6 , supersaturated between a $\mathrm{pH}$ of 6 to a $\mathrm{pH}$ of 8 , and undersaturated at higher $\mathrm{pH}$. Under conditions where illite is undersaturated, it may dissolve and be an important source of ions. Under conditions where illite is supersaturated, it may be an important mineral phase or a participant in ion exchange processes.

\section{Reduction and Oxidation Processes}

The first principal component (table 9) has significant positive loadings for iron, manganese, arsenic, barium, silica, ammonia, chloride, and bromide, and significant negative loadings for nitrate $\left(\mathrm{NO}_{3}\right)$, dissolved oxygen, uranium, and potassium. This principal component reflects redox processes, explains 23 percent of the variance, and is likely related to 
Table 9. Principal component analysis showing distribution of eigenvector loadings and significant Spearman correlation coefficients for variables not included in the principal component analysis model.

[Shading indicates significant loadings on each component ( $\mathrm{p}<0.001$ ); PC, principal component; redox, reduction oxidation potential; $\mathrm{Cl}-\mathrm{Br}$, chloride-bromide; --, Spearman correlation coefficient not significant $(\mathrm{p}<0.001)]$

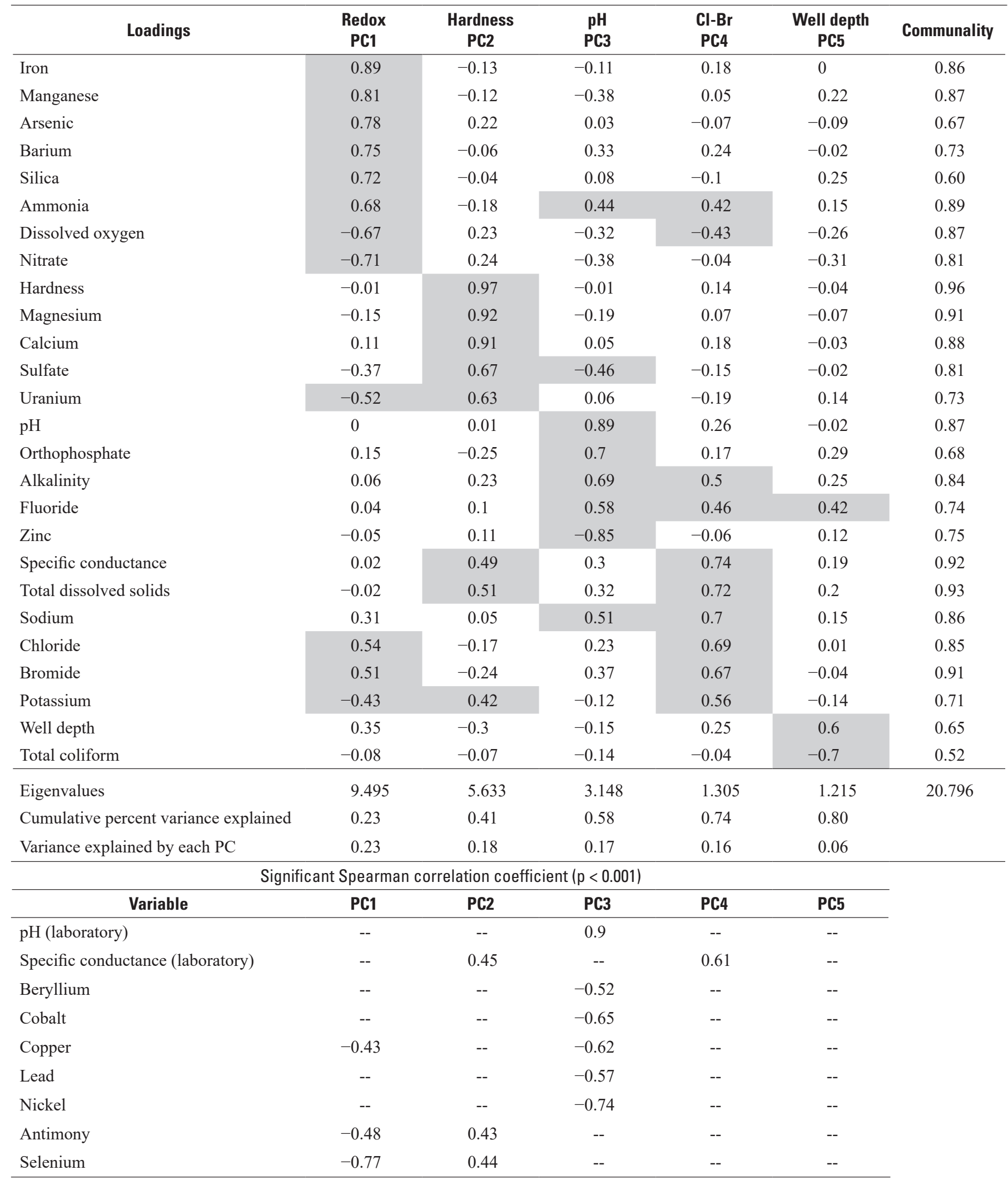



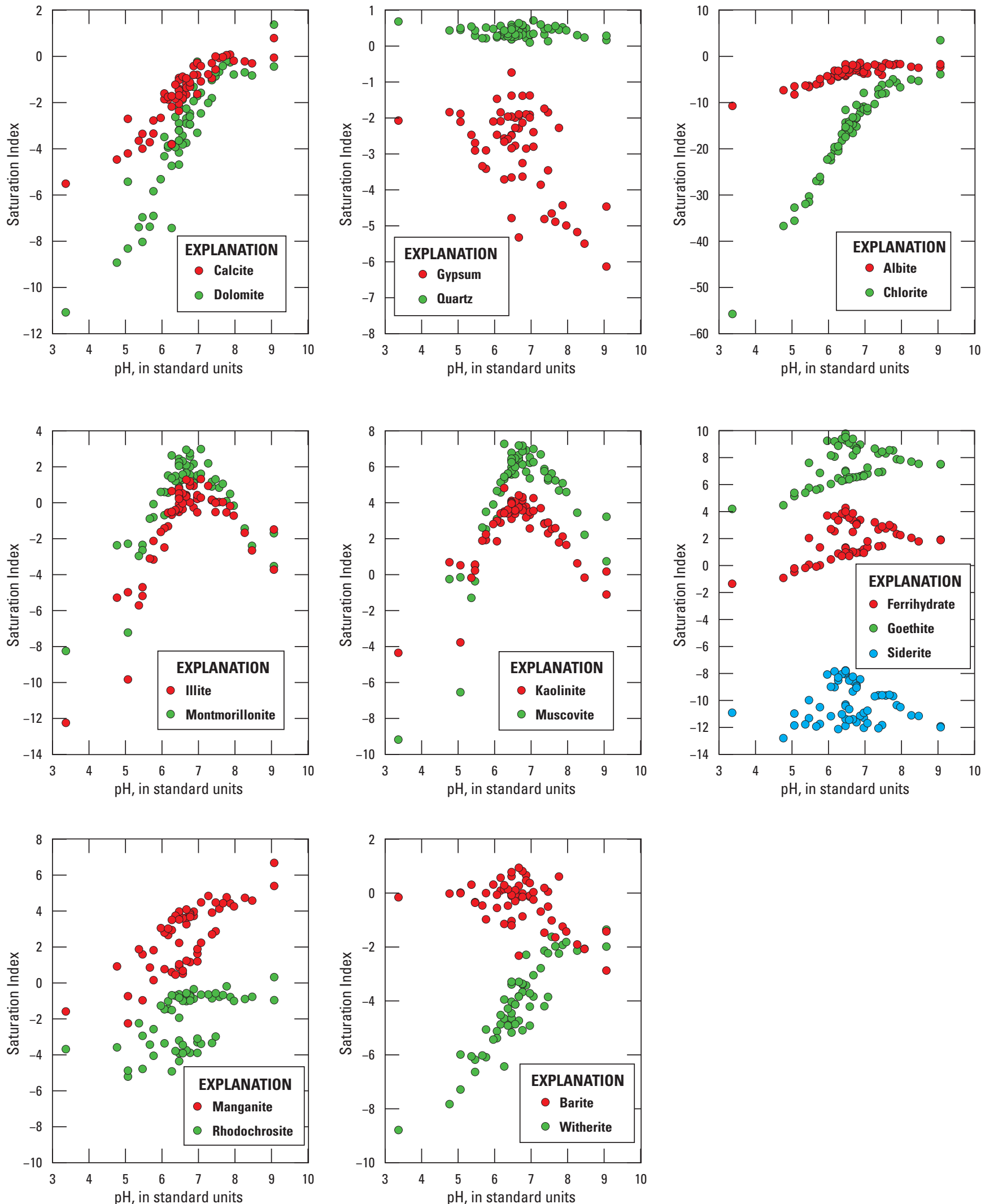

Figure 20. Saturation indices for selected mineral phases computed using the geochemical model, PHREEOC. 
geochemical processes occurring in shallow oxic groundwater or deeper anoxic groundwater. The strong positive loadings for iron, manganese, barium, and arsenic are correlated with reducing conditions often found deeper in the aquifer. More oxic water is correlated with the oxidation of nitrogen to nitrate and environmental mobilization of uranium (Jurgens and others, 2010; Langmuir, 1978), which is indicative of oxic, shallow groundwater systems. Hydrous iron oxides such as ferrihydrite and goethite are supersaturated in this system (fig. 20) and are expected to be a controlling factor in oxic conditions for the trace metals iron and manganese.

\section{Hardness}

The second principal component has significant positive loadings for specific conductance, total dissolved solids, hardness, calcium, magnesium, potassium, sulfate, and uranium (table 9). This component explains 18 percent of the variance and is indicative of constituents that contribute to hardness in groundwater with the highest loadings in dissolved calcium, magnesium, sulfate, and uranium. High concentrations of calcium and magnesium are associated with the undersaturation and dissolution of calcite and dolomite (fig. 20) from limestones in shallow parts of the aquifer at lower $\mathrm{pH}$. This part of the aquifer also is associated with higher sulfate concentrations where sulfide oxidation is important and sulfate reduction is less prevalent. Uranium mobilization also is more common in the shallow, oxic parts of the aquifer and increases with uranyl-carbonate complexation (Langmuir, 1978; Chapman and others, 2013; Fox and others, 2006).

\section{pH}

The third principal component had significant positive loadings for $\mathrm{pH}$, alkalinity, sodium, ammonia, fluoride, and orthophosphate, and significant negative loadings for sulfate and zinc. This component explains 17 percent of the variance, and has very strong loadings for $\mathrm{pH}$, alkalinity, orthophosphate, and zinc, which is indicative of $\mathrm{pH}$ control on these variables. Alkalinity is the acid-neutralizing capacity of the sample and it decreases with increasing acidity and subsequently decreasing $\mathrm{pH}$. Orthophosphate has a high capacity for sorption onto hydrous iron oxides and this process is dependent on $\mathrm{pH}$. As $\mathrm{pH}$ decreases, oxide surfaces become more positively charged and have a greater capacity to adsorb orthophosphate; as $\mathrm{pH}$ increases, hydrous iron oxides have less capacity to adsorb orthophosphate (Domagalski and Johnson, 2011). Orthophosphate is positively correlated with $\mathrm{pH}$ and $\mathrm{pH}$ is most likely an important control on orthophosphate mobility (appendix 1; table 9). Sorption on oxide surfaces also is most likely affecting zinc concentrations. In this case, it is an inverse relation where decreased $\mathrm{pH}$ decreases oxide surfaces and hydrous iron oxides have less capacity to adsorb zinc, resulting in higher dissolved zinc concentrations (Kent and others, 2007).

\section{Total Dissolved Solids, Chloride, Bromide, and Sodium}

The fourth principal component has significant positive loadings for specific conductance, total dissolved solids, alkalinity, potassium, sodium, bromide, chloride, and fluoride, and it has significant negative loadings for dissolved oxygen. This principal component explains 16 percent of the variance and is indicative of variables that control the introduction of the relatively conservative constituents, chloride and bromide. The chloride and bromide mass ratio $(\mathrm{Cl} / \mathrm{Br})$ is useful in understanding possible sources of chloride, bromide, and sodium in aquifers. These constituents can come from multiple sources including natural brines, cation exchange processes, and anthropogenic influence such as wastewater or road deicing salts. When the $\mathrm{Cl} / \mathrm{Br}$ mass ratio is large, it indicates lower values of bromide and greater influence from anthropogenic sources. When the $\mathrm{Cl} / \mathrm{Br}$ mass ratio is small, it indicates that natural brines may have more influence on chloride and bromide concentrations. A plot of the $\mathrm{Cl} / \mathrm{Br}$ mass ratio and chloride concentration is shown in figure 21. Many of the samples have a $\mathrm{Cl} / \mathrm{Br}$ ratio that is close to 100 , which is indicative of influence from deeper groundwater brine sources. The samples that have $\mathrm{Cl} / \mathrm{Br}$ ratio values close to and above 1,000 have lower concentrations of bromide and most likely have some influence from anthropogenic activities. Sodium has a relatively higher molar concentration than chloride and could have multiple sources including the dissolution of clay minerals, cation exchange processes, and wastewater. These results indicate that chloride, bromide, and sodium concentrations are likely controlled by multiple anthropogenic and natural sources in southern West Virginia.

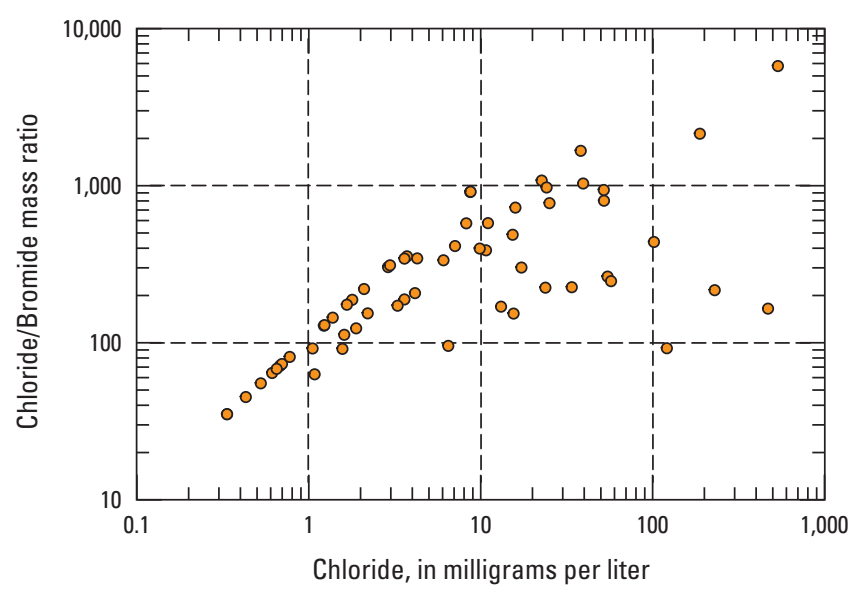

Figure 21. Chloride to bromide mass ratio and chloride concentration for 60 sites in the West Virginia southern coal-field province. 


\section{Well Depth}

The fifth principal component has significant positive loadings for well depth and fluoride and significant negative loadings for total coliforms. This principal component explains 6 percent of the variance and is indicative of variables that are affected by well depth. Springs and mine outfalls were considered to have a well depth of zero as samples were collected at the land surface. These sites also had a high occurrence of total coliforms and $E$. coli bacteria. Conversely, the wells that were sampled had a lower occurrence of bacteria that generally decreased with increasing well depth. This inverse correlation of well depth and bacteria indicates that deeper wells generally have less bacterial contamination and outfalls generally have more bacterial contamination in southern West Virginia.

\section{Summary}

West Virginia's southern coal-field province is composed of parts of 10 counties in the southern part of the State of West Virginia and has been and continues to be extensively mined for coal. The area is part of the Central Appalachian Basin Coal Province and coal mining activity in the area dates to the mid-1800s. The area is one of the most intensely mined areas within the United States with respect to the extraction of coal, both by surface and underground methods. Recent studies by the Centers for Disease Control and Prevention and other entities have shown that mortality rates for a variety of serious chronic conditions, such as diabetes, heart disease, and some forms of cancer in Appalachian coal mining regions, are higher than national averages.

To assess the potential of groundwater quality being a contributor to increased mortality and morbidity in West Virginia's southern coal-field province, water-quality samples were collected from 60 sites in a 10-county area in southern West Virginia, in areas with a high density of current or past coal mining. The 60 sites sampled included 46 rural-residential homeowner wells and 14 mine outfall discharges. Mine outfall discharges, commonly referred to as mine outfalls, are a common and unregulated source of water for residents of southern West Virginia. As rural-residential wells and mine outfalls are unregulated, and since there was a lack of available groundwater-quality data for the study area, the 60 sites were sampled for a broad range of common constituents including nitrate, nitrite, iron, manganese, sulfate, methane and radon gases, dissolved hydrocarbon gases, trace elements, common ions, and indicator bacteria. The objective of this study was to assess groundwater quality of source water from the aquifers sampled. Data used for analysis in this report were based on raw water samples collected prior to any water treatment systems, and prior to entry into rural-residential homeowners' plumbing systems; therefore, these data may not be reflective of water chemistry derived from the tap.
Generally, data for the 60 sites sampled indicate that most sites did not exceed drinking-water standards for many of the various U.S. Environmental Protection Agency (EPA) drinking-water standards and U.S. Geological Survey (USGS) health-based screening levels (HBSLs). However, there were several notable exceptions. Iron, manganese, turbidity, and total dissolved solids (TDS) were the most common contaminants to exceed drinking-water standards.

Turbidity exceeded the 5-Nephelometric Turbidity Unit (NTU) EPA treatment technique (TT) drinking-water standard in 14 of 60 (23 percent) sites sampled and exceeded the 1-NTU TT standard in 51 of 60 ( 85 percent) sites sampled. Turbidity is common in many wells in southern West Virginia and may be related to iron oxyhydroxide precipitates, sediment carried into the aquifer from the shallow soil zone due to improperly constructed or cased wells or transported to the aquifer in shallow stress-relief fracture zones.

The Langelier Saturation Index (LSI) and the potential to promote galvanic corrosion (PPGC) were used as indicators of the corrosivity of the water. Based on the LSI, 82 percent of the sites had waters that were classified as potentially corrosive. Only one of the sites (1.7 percent) sampled had a PPGC that was considered high, and the remaining sites were classified as having either a moderate (53.3 percent) or low (45 percent) PPGC.

Total coliform bacteria and Escherichia coli (E. coli) were detected in groundwater samples. Total coliforms are common in groundwater in southern West Virginia and were detected in 39 of the 60 sites ( 65 percent) sampled. The presence of total coliform bacteria is an indicator of potential surface contamination caused by improperly constructed or cased wells or by infiltration of soil or other surface contaminants into the aquifer or well bore. The presence of total coliform bacteria is not necessarily an indicator of potential pathogens but indicates that the well may be subject to bacterial and viral pathogens. E. coli bacteria, however, are indicative of direct fecal contamination. Fourteen of the 60 ( 23 percent) sites sampled contained E. coli; their presence in groundwater may be an indicator of other pathogens and should be regarded as a serious issue requiring treatment to kill any pathogens that may be present in the source water.

Manganese and iron were the second and third most prevalent contaminants detected in the groundwater samples collected for this study, with 30 of 60 (50 percent) sites analyzed for manganese and 25 of 60 (42 percent) sites analyzed for iron exceeding the proposed EPA 50- and 300-micrograms per liter $(\mu \mathrm{g} / \mathrm{L})$ Secondary Maximum Contaminant Level (SMCL) drinking-water standards, respectively, for aesthetic criteria such as taste, odor, or staining of plumbing fixtures. Fourteen of the 60 sites sampled ( 23 percent) had concentrations of manganese that exceeded the $300-\mu \mathrm{g} / \mathrm{L}$ USGS HBSL, and 1 site exceeded the 1,600- $\mu \mathrm{g} / \mathrm{L}$ EPA drinking-water equivalent level, which is based on a lifetime exposure level. Sodium has an EPA health-based value (HBV) of 20 milligrams per liter $(\mathrm{mg} / \mathrm{L})$ for individuals who are on a sodium-restricted diet for blood pressure or other health reasons. Sodium is another 
common constituent in groundwater within the study area. Sodium concentrations were elevated in a large proportion of the sites sampled, with 27 of 60 (45 percent) exceeding the 20-mg/L EPA HBV.

Some trace metals can present health risks or cause aesthetic problems if present in drinking water at elevated concentrations. The EPA Maximum Contaminant Levels (MCLs) for barium $(2,000 \mu \mathrm{g} / \mathrm{L})$ and beryllium $(4 \mu \mathrm{g} / \mathrm{L})$ were respectively exceeded at 2 (3.3 percent) and 1 (1.7 percent) of the 60 sites sampled. The EPA TT and MCL drinkingwater standards for lead and arsenic are 15 and $10 \mu \mathrm{g} / \mathrm{L}$, respectively; none of the 60 sites sampled had lead or arsenic concentrations in excess of these standards. However, the EPA Maximum Contaminant Level Goal drinking-water standards for lead and arsenic are both $0 \mu \mathrm{g} / \mathrm{L}$, and 25 (41.7 percent) and 32 (53.3 percent) of the 60 sites sampled had detectable concentrations of lead and arsenic. The maximum lead and arsenic concentrations were 3.37 and $6.0 \mu \mathrm{g} / \mathrm{L}$, respectively. Aluminum does not have an EPA MCL but the SMCL for aluminum is $0.05-2.0 \mu \mathrm{g} / \mathrm{L}$, and 8 of 60 (13 percent) sites sampled had aluminum concentrations in excess of the EPA SMCL.

Radon, a carcinogenic radioactive gas known to cause lung cancer, was detected at concentrations at or exceeding the proposed 300-picocuries per liter (pCi/L) EPA MCL in 12 of the 60 (21.1 percent) sites sampled. Sites with radon gas concentrations exceeding the $300-\mathrm{pCi} / \mathrm{L}$ proposed MCL have the potential for airborne concentrations of radon to exceed the $4-\mathrm{pCi} / \mathrm{L}$ indoor air standard. Inhalation of radon can cause lung cancer, and the 4-pCi/L indoor air standard is based on an inhalation standard. Therefore, homeowners whose wells have radon gas concentrations exceeding $300 \mathrm{pCi} / \mathrm{L}$ may be advised to have their indoor air tested to determine if indoor air concentrations exceed the 4-pCi/L indoor air standard established by the EPA. Of the 12 sites at or exceeding the $300-\mathrm{pCi} / \mathrm{L}$ drinking-water standard, 8 (67 percent of MCL exceedances) were for sites deriving water from the Kanawha Formation, 3 (25 percent of MCL exceedances) were for sites deriving water from the New River Formation, and only 1 site was for water deriving from the Pocahontas Formation ( 8 percent of proposed MCL exceedances).

Various factors were analyzed statistically and graphically to determine whether they have an influence on groundwater quality within the study area, including topographic setting, well depth, type of mining (surface or underground), type of site (well or mine outfall), and geologic formation. None of the factors assessed were shown to affect the overall water chemistry of the sites sampled except for geologic formation and the type of sites sampled.

Sites sampled for this study included 46 wells and 14 mine outfalls. The overall chemistry of outfalls and wells was quite different, with outfalls being dominated by much higher dissolved oxygen content than deeper wells. The dissolved oxygen content is the primary component driving the oxidation and reduction of minerals, and the precipitation of minerals that are saturated or supersaturated with respect to various cations and anions. This was the case for the sites sampled for this study as median dissolved oxygen concentrations were $8.75 \mathrm{mg} / \mathrm{L}$ for the outfall samples and $0.4 \mathrm{mg} / \mathrm{L}$ for the well samples. Median concentrations of sulfate and selenium were much higher in waters from the outfalls sampled, with median concentrations of $73.8 \mathrm{mg} / \mathrm{L}$ and $2.35 \mu \mathrm{g} / \mathrm{L}$, respectively, when compared to concentrations for the same constituents in waters from the wells sampled, which had median concentrations of $18.3 \mathrm{mg} / \mathrm{L}$ and less than the $0.05-\mu \mathrm{g} / \mathrm{L}$ method detection limit, respectively. The maximum selenium concentration was for a well, with a concentration of $16.6 \mu \mathrm{g} / \mathrm{L}$, far below the $50-\mu \mathrm{g} / \mathrm{L}$ EPA SMCL drinking-water standard. The geochemical processes responsible for sulfate and selenium concentrations in groundwater are similar and are a result of oxidation of sulfide minerals such as pyrite and ferroselite.

The overall water chemistry for the three principal geologic formations assessed for this study, the Pocahontas, New River, and Kanawha Formations, varied significantly with respect to several constituents. Median concentrations of calcium, magnesium, sodium, potassium, and TDS for sites in the Pocahontas Formation were 41.8, 18.6, 15.0, 2.10, and $312 \mathrm{mg} / \mathrm{L}$, respectively. The distribution of major ions was similar for the New River and Kanawha Formations. Sites in the New River Formation had median calcium, magnesium, sodium, potassium, and TDS concentrations of 20.2, 7.18, $10.4,1.43$, and $166 \mathrm{mg} / \mathrm{L}$, respectively; sites in the Kanawha Formation had median concentrations of $26.4,8.14,21.2,2.32$, and $248 \mathrm{mg} / \mathrm{L}$ for the same respective constituents.

For those constituents commonly associated with mining activity, the highest concentrations were for sites sampled in the New River Formation. Median concentrations of iron, manganese, sulfate, and median $\mathrm{pH}$ values for sites sampled in the New River Formation were 2,440 $\mu \mathrm{g} / \mathrm{L}, 482 \mu \mathrm{g} / \mathrm{L}$, $21.2 \mathrm{mg} / \mathrm{L}$, and 6.35 standard units, respectively. Median concentrations of iron, manganese, sulfate, and median $\mathrm{pH}$ values for sites sampled in the Pocahontas Formation were $27.6 \mu \mathrm{g} / \mathrm{L}, 2.28 \mu \mathrm{g} / \mathrm{L}, 64.0 \mathrm{mg} / \mathrm{L}$, and 6.5 standard units, respectively. Median concentrations of iron, manganese, sulfate, and median $\mathrm{pH}$ values for sites sampled in the Kanawha Formation were $56.8 \mu \mathrm{g} / \mathrm{L}, 13.0 \mu \mathrm{g} / \mathrm{L}, 25.3 \mathrm{mg} / \mathrm{L}$, and 6.80 standard units, respectively. The concentrations of iron and manganese in the New River Formation were statistically significantly higher than concentrations in either the Pocahontas or Kanawha Formations.

Dissolved hydrocarbons, including methane, ethane, propane, propene, $n$ - and $i$-butane, 1 -butene, $n$ - and $i$-pentane, pentane, 2- and 3-ethyl pentane, hexane, and benzene were analyzed in samples collected from 59 of the 60 sites to evaluate the potential for methane in groundwater and to identify the potential sources of methane and other gases in groundwater within the study area. Results of the analysis indicated that most of the gas is of shallow, biogenic origin, possibly associated with coal-bed methane, but a subset of samples had a gas signature and chloride to bromide ratios indicative of potential mixing with deeper thermogenic gases. Only 2 of the 59 (3.4 percent) sites sampled had concentrations of methane gas, which is a highly combustible and explosive gas exceeding the 
10-mg/L level of concern established by the Office of Surface Mining Reclamation and Enforcement (OSMRE), and only 1 of the 59 (1.7 percent) sites sampled had a methane concentration in excess of the $28-\mathrm{mg} / \mathrm{L}$ criteria, the level at which OSMRE recommends implementing mitigation strategies to remediate the explosion hazard.

Mineral phases present within the bedrock and soil zones near a sample site are important in controlling solute concentrations in groundwater. The presence of minerals can vary spatially with depositional environment and were assessed by calculating saturation indices using geochemical modeling software. Results of the geochemical modeling indicate that calcite and dolomite, which are the major constituents of limestone and may also be present as cements in calcareous clastic rocks, are generally undersaturated and may dissolve at low $\mathrm{pH}$. Consequently, these carbonate minerals are an important source of calcium and magnesium in the study area. Other carbonate minerals including siderite, rhodochrosite, and witherite also may be important because of their possible control on the trace elements iron, manganese, and barium. These three elements have a significant inverse correlation with dissolved oxygen and are highly dependent on redox processes as well as dissolved carbonate. Siderite is undersaturated in groundwater in the study area and may dissolve, which means it may be an important source of dissolved iron concentrations. The oxidation of pyrite and other sulfide minerals, which produce dissolved sulfate $\left(\mathrm{SO}_{4}\right)$, could be another source of iron plus sulfate. Sulfate concentrations can decrease in this environment through dilution, reduction of sulfate to hydrogen sulfide, or precipitation of sulfate minerals. Although those processes can decrease sulfate concentrations, sulfate is still much higher than iron in the study area, which means that the precipitation of iron minerals may be acting as a sink for iron in southern West Virginia. Barium has a significant inverse correlation with low dissolved oxygen, and the SI for barite ranged from undersaturated to supersaturated. The inverse correlation between barium and dissolved oxygen indicates that barium may be released to solution by the reductive dissolution of barite. Sulfide mineral dissolution and subsequent oxidation to sulfate occurs in more oxic settings (shallow aquifers), whereas in groundwater systems where there is low dissolved oxygen (deeper aquifers), sulfate reduction can be an important process to remove sulfate from solution. These processes can effectively increase the possibility of barite precipitation in oxic aquifers that have high sulfate concentrations and decrease precipitation of barium in anoxic aquifers experiencing sulfate reduction.

Other factors that may affect the concentrations of major and trace constituents in groundwater in the study area include exchange reactions, adsorption, and dissolution of aluminosilicate minerals. Albite $\left(\mathrm{NaAlSi}_{3} \mathrm{O}_{8}\right)$ and chlorite $\left(\mathrm{Mg}_{5} \mathrm{Al}_{2} \mathrm{Si}_{3} \mathrm{O}_{10}[\mathrm{OH}]_{8}\right)$ are both undersaturated for the range of $\mathrm{pH}$ and would be expected to dissolve at low $\mathrm{pH}$ in the study area, which could release aluminum ( $\mathrm{Al}$ ) and silica $(\mathrm{Si})$ into solution. Silica and aluminum most likely are retained as kaolinite $\left(\mathrm{Al}_{2} \mathrm{Si}_{2} \mathrm{O}_{5}[\mathrm{OH}]_{4}\right)$, gibbsite $\left(\mathrm{Al}[\mathrm{OH}]_{3}\right)$, and quartz $\left(\mathrm{SiO}_{2}\right)$. These minerals are supersaturated over most of the $\mathrm{pH}$ range and they were identified in the petrographic analysis of rock samples for a previous study conducted in the study area. Illite $\left(\mathrm{K}_{0.6} \mathrm{Mg}_{0.25} \mathrm{Al}_{2.3} \mathrm{Si}_{3.5} \mathrm{O}_{10}[\mathrm{OH}]_{2}\right)$ was undersaturated below a $\mathrm{pH}$ of 6 , supersaturated between a $\mathrm{pH}$ of 6 to 8 , and undersaturated at high $\mathrm{pH}$. Under conditions where illite is undersaturated, it may dissolve and be an important source of ions. Under conditions where illite is supersaturated, it may be an important mineral phase or contribute to ion exchange processes.

Principal components analysis of the data collected during the study was used to assess the primary geochemical processes occurring in the aquifers sampled. Results of the analysis indicate that iron, manganese, barium, and arsenic are correlated with reducing conditions that are commonly found deeper in the aquifer. More oxic water is correlated with oxidation of nitrogen to nitrate and environmental mobilization of uranium, which is indicative of oxic, shallow groundwater systems. High concentrations of calcium and magnesium are associated with the undersaturation and dissolution of calcite and dolomite from limestones in shallow parts of the system at lower $\mathrm{pH}$. This zone in the aquifer also is associated with higher sulfate concentrations where sulfide oxidation is important and sulfate reduction is less prevalent. Uranium mobilization also is more common in the shallow, oxic parts of the aquifer and uranium has been shown to increase in mobility in the presence of calcium ions where sorption onto hydrous iron oxides $\left(\mathrm{Fe}[\mathrm{OH}]_{3}[\mathrm{a}]\right)$ is decreased. As $\mathrm{pH}$ decreases, oxide surfaces become more positively charged and have a greater capacity to adsorb orthophosphate; as $\mathrm{pH}$ increases, hydrous iron oxides have less capacity to adsorb orthophosphate. A similar sorption effect on oxides is most likely affecting zinc concentrations, but is an inverse relation where $\mathrm{pH}$ decreases, hydrous iron oxides have less capacity to adsorb zinc and more zinc is released into solution. The chloride-bromide mass ratio is useful in understanding possible sources of chloride, bromide, and sodium in systems. These constituents can come from multiple sources including natural brines, cation exchange processes, and anthropogenic influence such as wastewater or road deicing salts. Many of the sites sampled had a chloride-bromide mass ratio that was close to 100 , which is indicative of influence from deeper groundwater brine sources. A few samples had chloride-bromide mass ratio values close to and above 1,000 , indicative of anthropogenic influences such as road salt and wastewater. 


\section{References Cited}

American Public Health Association, American Water Works Association, Water Environment Foundation, 2017, Standard methods for the examination of water and wastewater. Enzyme Substrate Coliform Test: accessed February 5, 2018, at https://www.standardmethods.org/action/doSearch? AllField $=$ Enzyme + Substrate + Coliform + Test.

Arkle, T., Jr., Beissel, D.R., Larese, R.E., Nuhfer, E.B., Patchen, D.G., Smosna, R.A., Gillespie, W.H., Lund, R., Norton, C.W., and Pfefferkorn, H.W., 1979, section D, U.S. Geological Survey Professional Paper 1110 A-L, p. D1-D26.

Back, W., 1966, Hydrochemical facies and ground-water flow patterns in northern part of Atlantic Coastal Plain: U.S. Geological Survey Professional Paper 498-A, p. A1-A42, accessed February 7, 2019, at https://pubs.er.usgs.gov/ publication/pp498A.

Bader, J.S., Mathes, M.V., and Runner, G.S., 1989, Water resources of the Tug Fork River Basin, West Virginia, Kentucky, and Virginia and Twelvepole Creek Basin, West Virginia: Morgantown, West Virginia, West Virginia Geological and Economic Survey River Basin Bulletin RBB-8, 113 p.

Belitz, K., Jurgens, B.C., and Johnson, T.D., 2016, Potential corrosivity of untreated groundwater in the United States: U.S. Geological Survey Scientific Investigations Report 2016-5092, 16 p., accessed February 7, 2019, at https:// doi.org/10.3133/sir20165092.

Benjamin, M.M., 2002, Water chemistry: Long Grove, Illinois, Waveland Press, $668 \mathrm{p}$.

Berg, T.M., Edmunds, W.E., Geyer, A.R., Glover, A.D., Hoskins, D.M., MacLachlan, D.B., Root, S.I., Sevon, W.D., Socolow, A.A., Miles, C.E., and Kuchinski, J.G., 1980, Geologic Map of Pennsylvania: Pennsylvania Department of Environmental Resources, Bureau of Topographic and Geologic Survey State Geologic Map, 2 sheets, scale $1: 250,000$.

Borchers, J.W., Ehlke, T.A., Mathes, M.V., Jr., and Downs, S.C., 1991, The effects of coal mining on the hydrologic environment of selected stream basins in southern West Virginia: U.S. Geological Survey Water-Resources Investigations Report 84-4300, 119 p., accessed February 7, 2019, at https://pubs.er.usgs.gov/publication/wri844300.

Bruhn, R.W., 1985, A note on ground movements and associated ground water responses at an underground Appalachian mine: Society for Mining, Metallurgy and ExplorationAmerican Institute of Mining, Metallurgical and Petroleum Engineers reprint 85-63, $10 \mathrm{p}$.
Callaghan, T., Fleeger, G.M., Barnes, S., and Dalberto, A., 1998, Groundwater flow on the Appalachian Plateau of Pennsylvania, chap. 2 of Brady, K.B.C., Smith, M.W., and Schueck, J., eds., Coal mine drainage prediction and pollution prevention in Pennsylvania: Harrisburg, Pennsylvania, Pennsylvania Department of Environmental Protection, 5600-BK-DEP2256 8/98, p. 2-1 to 2-39, accessed June 7, 2019, at http://files.dep.state.pa.us/Mining/ BureauOfMiningPrograms/BMPPortalFiles/Coal_Mine_ Drainage_Prediction_and_Pollution_Prevention_in_Pennsylvania.pdf.

Cardwell, D.H., Erwin, R.B., and Woodward, H.P., 1968, Geologic map of West Virginia: West Virginia Geological and Economic Survey, 2 sheets, scale 1:250,000.

Cecil, C.B., Stanton, R.W., Neuzil, S.G., DuLong, F.T., Ruppert, L.F., and Pierce, B.S., 1985, Paleoclimate controls on late paleozoic sedimentation and peat formation in the central appalachian Basin (USA): International Journal of Coal Geology, v. 5, nos. 1-2, p. 195-230, accessed February 7, 2019, at https://doi.org/10.1016/0166-5162(85)90014-X.

Chambers, D.B., Kozar, M.D., Messinger, T., Mulder, M.L., Pelak, A.J., and White, J.S., 2015, Water quality of groundwater and stream base flow in the Marcellus Shale Gas Field of the Monongahela River Basin, West Virginia, 2011-12 (ver. 1.1, June 25, 2015): U.S. Geological Survey Scientific Investigations Report 2014-5233, 75 p., accessed February 7, 2019, at https://doi.org/10.3133/sir20145233.

Chambers, D.B., Kozar, M.D., White, J.S., and Paybins, K.S., 2012, Groundwater quality in West Virginia, 1993-2008: U.S. Geological Survey Scientific Investigations Report 2012-5186, 47 p., accessed February 7, 2019, at https:// pubs.usgs.gov/sir/2012/5186/.

Chapman, M.J., Cravotta, C.A., III, Szabo, Z., and Lindsey, B.D., 2013, Naturally occurring contaminants in the Piedmont and Blue Ridge crystalline-rock aquifers and Piedmont Early Mesozoic Basin siliciclastic-rock aquifers, Eastern United States, 1994-2008: U.S. Geological Survey Scientific Investigations Report 2013-5072, 74 p., accessed February 7, 2019, at http://pubs.usgs.gov/sir/2013/5072/.

Colosimo, F., Thomas, R., Lloyd, J.R., Taylor, K.G., Boothman, C., Smith, A.D., Lord, R., and Kalin, R.M., 2016, Biogenic methane in shale gas and coal bed methane: A review of current knowledge and gaps: International Journal of Coal Geology, v. 165, p. 106-120, accessed February 7, 2019, at https://doi.org/10.1016/j.coal.2016.08.011. 
Cozzarelli, I.M., Skalak, K.J., Kent, D.B., Engle, M.A., Benthem, A., Mumford, A.C., Haase, K., Farag, A., Harper, D., Nagel, S.C., Iwanowicz, L.R., Orem, W.H., Akob, D.M., Jaeschke, J.B., Galloway, J., Kohler, M., Stoliker, D.L., and Jolly, G.D., 2017, Environmental signatures and effects of an oil and gas wastewater spill in the Williston Basin, North Dakota: Science of The Total Environment, v. 579, p. 1781-1793, accessed February 8, 2019, at https://doi.org/10.1016/j.scitotenv.2016.11.157.

Cravotta, C.A., III, 2008, Dissolved metals and associated constituents in abandoned coal-mine discharges, Pennsylvania, USA. Part 2: Geochemical controls on constituent concentrations: Applied Geochemistry, v. 23, no. 2, p. 203-226, accessed February 7, 2019, at https:// doi.org/10.1016/j.apgeochem.2007.10.003.

Cravotta, C.A., III, Sherrod, L., Galeone, D.G., Lehman, W.G., Ackman, T.E., and Kramer, A., 2017, Hydrological and geophysical investigation of streamflow losses and restoration strategies in an abandoned mine lands setting: Environmental \& Engineering Geoscience, v. 23, no. 4, p. 243-273, accessed February 7, 2019, at https://pubs.er.usgs. gov/publication/70193819.

Davis, J.C., 1986, Statistics and data analysis in geology (2d ed.): New York, John Wiley \& Sons, 646 p.

Domagalski, J.L., and Johnson, H.M., 2011, Subsurface transport of orthophosphate in five agricultural watersheds, USA: Journal of Hydrology, v. 409, nos. 1-2, p. 157-171, accessed February 7, 2019, at https:// doi.org/10.1016/j.jhydrol.2011.08.014.

Ehlke, T.A., Bader, J.S., Puente, C., and Runner, G.S., 1982a, Hydrology of Area 12, Eastern Coal Province, West Virginia: U.S. Geological Survey Water-Resources Investigations Report 81-902, 75 p.

Ehlke, T.A., Runner, G.S., and Downs, S.C., 1982b, Hydrology of Area 9, Eastern Coal Province, West Virginia: U.S. Geological Survey Water-Resources Investigations Report 81-803, 63 p.

Eltschlager, K.K., Hawkins, J.W., Ehler, W.C., and Baldassare, F., 2001, Technical measures for the investigation and mitigation of fugitive methane hazards in areas of coal mining: Pittsburgh, Pennsylvania, Office of Surface Mining Reclamation and Enforcement, 124 p., accessed June 7, 2019, at https://www.osmre.gov/resources/blasting/docs/ MineGasesDust/Methane.pdf.

ESRI, 2015, ArcGIS for Desktop Release 10.3.1, Redlands, California, Environmental Systems Research Institute, accessed November 15, 2019, at https://desktop.arcgis.com/ en/arcmap/10.3/get-started/quick-start-guides/arcgis-desktop-quick-start-guide.htm.
Fenneman, N.M., 1938, Physiography of Eastern United States: New York, McGraw-Hill, 714 p.

Fenneman, N.M., and Johnson, D.W., 1946, Physiographic divisions of the conterminous United States: U.S. Geological Physiography Committee Special Map, 1 sheet, scale $1: 7,000,000$.

Ferguson, H.F., 1967, Valley stress relief in the Allegheny Plateau: Association of Engineering Geologists Bulletin, v. 4 , no. 1 , p. $63-71$.

Ferrell, G.M., 1992, Hydrologic characteristics of abandoned coal mines used as sources of public water supply in McDowell County, West Virginia: U.S. Geological Survey Water-Resources Investigations Report 92-4073, 37 p., accessed February 7, 2019, at https://doi.org/10.3133/ wri924073.

Foster, J.B., 1980, Fresh and saline ground-water map of West Virginia: West Virginia Geological and Economic Survey Map Report WV-12, 4 sheets, scale 1:250,000.

Fox, P.M., Davis, J.A., and Zachara, J.M., 2006, The effect of calcium on aqueous uranium (VI) speciation and adsorption to ferrihydrite and quartz: Geochimica et Cosmochimica Acta, v. 70, no. 6, p. 1379-1387, accessed February 8, 2019, at https://doi.org/10.1016/j.gca.2005.11.027.

Haase, K.B., Busenberg, E., Plummer, L.N., Casile, G., and Sanford, W.E., 2014, Measurements of HFC-134a and HCFC-22 in groundwater and unsaturated-zone air: Implications for HFCs and HCFCs as dating tracers: Chemical Geology, v. 385, p. 117-128, at https:// doi.org/10.1016/j.chemgeo.2014.07.016.

Haase, K.B., Kozar, M.D., McAdoo, M.A., Casile, G.C., Steffy, L., Risser, D.W., Heilweil, V.M., and Mumford, A.C., 2018, Dataset of trace dissolved hydrocarbons in surface water and groundwater in North Dakota, Pennsylvania, Virginia, and West Virginia between 2014 and 2017: U.S. Geological Survey data release, accessed February 12, 2019 at https://doi.org/10.5066/P9RDPWXO.

Hach, 2019, Documentation of Hach product 223801, which uses a modified version of EPA Method 376.2, which is a rapid colorimetric reagent-based analytical method for determination of hydrogen sulfide in water: Hach Corporation web site, accessed February 12, 2019, at https://www. hach.com/hydrogen-sulfide-color-disc-test-kit-model-hs-wr/ product $? \mathrm{id}=7640219544 \&$ callback $=\mathrm{qs}$.

Hanshaw, B.B., and Back, W., 1979, Major geochemical processes in the evolution of carbonate-aquifer systems: Journal of Hydrology, v. 43, p. 287-312. 
Harkness, J.S., Darrah, T.H., Warner, N.R., Whyte, C.J., Moore, M.T., Millot, R., Kloppmann, W., Jackson, R.B., and Vengosh, A., 2017, The geochemistry of naturally occurring methane and saline groundwater in an area of unconventional shale gas development: Geochimica et Cosmochimica Acta, v. 208, p. 302-334, accessed February 8, 2019, at https://doi.org/10.1016/j.gca.2017.03.039.

Harlow, G.E., Jr., and LeCain, G.D., 1993, Hydraulic characteristics of, and ground-water flow in, coal-bearing rocks of southwestern Virginia: U.S. Geological Survey Water-Supply Paper 2388, 36 p., accessed February 8, 2019, at https:// pubs.usgs.gov/wsp/wsp_2388/.

Hawkins, J.W., 1998a, Hydrogeologic characteristics of surface-mine spoil, in Brady, K.B.C., Smith, M.W., and Schueck, J., eds., Coal mine drainage prediction and pollution prevention in Pennsylvania: Harrisburg, Pennsylvania, Pennsylvania Department of Environmental Protection, 5600-BK-DEP2256 8/98, p. 3-1 to 3-11.

Hawkins, J.W., 1998b, Remining, in Brady, K.B.C., Smith, M.W., and Schueck, J., eds., Coal mine drainage prediction and pollution prevention in Pennsylvania: Harrisburg, Pennsylvania, Pennsylvania Department of Environmental Protection, 5600-BK-DEP2256 8/98, p. 17-1 to 17-6.

Helsel, D.R., 2012, Statistics for censored environmental data using Minitab and R (2d ed.): Hoboken New Jersey, John Wiley \& Sons, $343 \mathrm{p}$.

Hem, J.D., 1992, Study and interpretation of the chemical characteristics of natural water: U.S. Geological Survey Water Supply Paper 2254, 264 p, accessed February 8, 2019, at https://pubs.usgs.gov/wsp/wsp2254/.

Heisig, P.M., and Scott, T.-M., 2013, Occurrence of methane in groundwater of south-central New York State, 2012Systematic evaluation of a glaciated region by hydrogeologic setting: U.S. Geological Survey Scientific Investigations Report 2013-5190, 32 p., accessed February 8, 2019, at https://doi.org/10.3133/sir20135190 .

Hendryx, M. and Ahern, M.M., 2009, Mortality in Appalachian coal mining regions: The value of statistical life lost: Public Health Reports, v. 124, no. 4, p. 541-550, accessed February 8, 2019, at https://www.ncbi.nlm.nih.gov/pmc/ articles/PMC2693168/.

IDEXX, 2019, Overview and resources for the Colilert method for processing and quantification of total coliform and $E$. coli bacteria: IDEXX corporation online web page, accessed May 15, 2018, at https://www.idexx.com/en/water/ water-products-services/colilert/.
Igari, S.-I., Maekawa, T., and Suzuki, Y., 2007, Pentane and hexane isomers in natural gases from oil and gas fields in Akita, Niigata and Hokkaido, Japan: Determination factor in their isomer ratios: Geochemical Journal, v. 41, no. 1, p. 57-63, accessed February 8, 2019, at https://www.jstage. jst.go.jp/article/geochemj/41/1/41_1_57/_article/-char/en.

Jurgens, B.C., Fram, M.S., Belitz, K., Burow, K.R., and Landon, M.K., 2010, Effects of groundwater development on uranium: Central Valley, California, USA: Groundwater, v. 48, no. 6, p. 913-928, accessed February 8, 2019, at https://doi.org/10.1111/j.1745-6584.2009.00635.x.

Kent, D.B., Wilkie, J.A., and Davis, J.A., 2007, Modeling the movement of a $\mathrm{pH}$ perturbation and its impact on adsorbed zinc and phosphate in a wastewater-contaminated aquifer: Water Resources Research, v. 43, no. 7, 17 p., accessed February 8,2019 , at https://doi.org/10.1029/2005WR004841.

Kiesler, J., Quinones, F., Mull, D.S., and York, K.L., 1983, Hydrology of Area 13, Eastern Coal Province, West Virginia: U.S. Geological Survey Water-Resources Investigations Report 82-505, $112 \mathrm{p}$.

Kozar, M.D., 1998, Ground-water age data applied to understanding fractured bedrock aquifers in West Virginia: Proceedings of the West Virginia Non-Point Source Conference, October 1-3, 1998, Charleston, West Virginia, p. 13.

Kozar, M.D., and Mathes, M.V., 2001, Aquifer-characteristics data for West Virginia: U.S. Geological Survey Water-Resources Investigations Report 01-4036, 74 p., accessed February 11, 2019, at https://pubs.usgs.gov/wri/ wri01-4036/.

Kozar, M.D., McCoy, K.J., Britton, J.Q., and Blake, B.M.B., Jr., 2012, Hydrogeology, groundwater flow, and groundwater quality of an abandoned underground coal-mine aquifer, Elkhorn Area, West Virginia: West Virginia Geological and Economic Survey Bulletin B-46, 103 p., accessed February 11, 2019, at http://downloads.wvgs.wvnet.edu/pubcat/ docs/Bulletin_46_Hydrogeology,\%20Groundwater\%20 Abandoned $\% 20$ Coal $\% 20$ Mine $\% 20$ Aquifer, $\% 20$ Elkhorn,\%20WV_(2012).pdf.

Kozar, M.D., and Paybins, K.S., 2016, Assessment of hydrogeologic terrains, well-construction characteristics, groundwater hydraulics, and water-quality and microbial data for determination of surface-water-influenced groundwater supplies in West Virginia: U.S. Geological Survey Scientific Investigations Report 2016-5048, 55 p., accessed February 11, 2019, at https://doi.org/10.3133/sir20165048.

Langmuir, D., 1978, Uranium solution-mineral equilibria at low temperatures with applications to sedimentary ore deposits: Geochemica et Cosmochimica Acta, v. 42, no. 6, part A, p. 547-569, accessed February 11, 2019, at https://www.sciencedirect.com/science/article/ pii/0016703778900017. 
Llewellyn, G.T., Dorman, F., Westland, J.L., Yoxtheimer, D., Grieve, P., Sowers, T., Humston-Fulmer, E., and Brantley, S.L., 2015, Evaluating a groundwater supply contamination incident attributed to Marcellus Shale gas development: Proceedings of the National Academy of Sciences of the United States of America (PNAS), v. 112, no. 20, p. 6325-6330, accessed February 11, 2019, at https://doi. org/10.1073/pnas. 1420279112 .

Lorenz, D.L., 2018, USGS-R/smwrQW: Tools for censored data analysis, Version 0.7.14: at https://rdrr.io/github/USGSR/smwrQW/.

Lorenz, D.L., and Diekoff, A.L., 2017, smwrGraphs-An R package for graphing hydrologic data, version 1.1.2: U.S. Geological Survey Open-File Report 2016-1188, 17 p., accessed February 11, 2019, at https://doi.org/10.3133/ ofr20161188.

Mathes, M.V., Jr., Kozar, M.D., and Brown, D.P., 1998, Summary of ground-water quality in West Virginia: West Virginia Division of Environmental Protection, Office of Water Resources, Ground-Water Program, 54 p.

Mathes, M.V., and White, J.S., 2006, Methane in West Virginia ground water: U.S. Geological Survey Fact Sheet 2006-3011, 2 p., accessed February 11, 2019, at https:// pubs.usgs.gov/fs/2006/3011/.

McAdoo, M.A., and Kozar M.D., 2017, Groundwaterquality data associated with abandoned underground coal mine aquifers in West Virginia, 1973-2016: Compilation of existing data from multiple sources: U.S. Geological Survey Data Series 1069, 7 p., accessed February 11, 2019, at https://doi.org/10.3133/ds1069.

McAuley, S.D., and Kozar, M.D., 2006, Ground-water quality in unmined areas and near reclaimed surface coal mines in the northern and central Appalachian coal regions, Pennsylvania and West Virginia: U.S. Geological Survey Scientific Investigations Report 2006-5059, 57 p., accessed February 11, 2019, at https://pubs.usgs.gov/sir/2006/5059/.

Milici, R.C., and Polyak, D.E., 2014, Bituminous coal production in the Appalachian Basin: Past, present, and future, chap. D.3 of Ruppert, L.F., and Ryder, R.T., eds., Coal and petroleum resources in the Appalachian basin: Distribution, geologic framework, and geochemical character: U.S. Geological Survey Professional Paper 1708, 13 p., accessed February 11, 2019, at https://doi.org/10.3133/pp1708D.3.

Molofsky, L.J., Connor, J.A., McHugh, T.E., Richardson, S.D., Woroszylo, C., and Alvarez, P.J., 2016, Environmental factors associated with natural methane occurrence in the Appalachian Basin: Groundwater, v. 54, no. 5, p. 656-668, accessed February 11, 2019, at https://doi.org/10.1111/ gwat.12401.
Molofsky, L.J., Connor, J.A., Wylie, A.S., Wagner, T., and Farhat, S.K., 2013, Evaluation of methane sources in groundwater in Northeastern Pennsylvania: Groundwater, v. 51, no. 3, p. 333-349, accessed February 11, 2019, at https:// doi.org/10.1111/gwat.12056.

Myers, D.N., Stoeckel, D.M., Bushon, R.N., Francy, D.S., and Brady, A.M.G., 2014, Fecal indicator bacteria (ver. 2.1): U.S. Geological Survey Techniques of Water-Resources Investigations, book 9, chap. A7, section 7.1, May 2014, accessed February 12, 2018, at http://pubs.water.usgs.gov/ twri9A/.

National Oceanic and Atmospheric Administration, 2018, Station Normals for West Virginia, 1981-2010, accessed September 20, 2019, at https://www.ncdc.noaa.gov/cdo-web/ datasets/NORMAL_ANN/locations/FIPS:54/detail.

Nguyen, C.K., Clark, B.N., Stone, K.R., and Edwards, M.A., 2011, Role of chloride, sulfate, and alkalinity on galvanic lead corrosion: Corrosion, v. 67, no. 6, 9 p., accessed February 11, 2019, at https://doi.org/10.5006/1.3600449.

Norman, J.E., Toccalino, P.L., Morman, S.A., 2018, HealthBased Screening Levels for evaluating water-quality data (2d ed.): U.S. Geological Survey web page, accessed February 11, 2019, at https://doi.org/10.5066/F71C1TWP.

Orem, W., Varonka, M., Crosby, L., Haase, K., Loftin, K., Hladik, M., Akob, D.M., Tatu, C., Mumford, A., Jaeschke, J., Bates, A., Schell, T., and Cozzarelli, I., 2017, Organic geochemistry and toxicology of a stream impacted by unconventional oil and gas wastewater disposal operations: Applied Geochemistry, v. 80, p. 155-167, accessed February 8, 2019 at https://doi.org/10.1016/j.apgeochem.2017.02.016.

Otton, J.K. 1992, The geology of radon: U.S. Geological Survey Special Publications pamphlet: U.S. Government Printing Office 1192 0-326-248, 30 p.

Ouyang, B., Akob, D.M., Dunlap, D., and Renock, D., 2017, Microbially mediated barite dissolution in anoxic brines: Applied Geochemistry, v. 76, p. 51-59, accessed February 11, 2019, at https://doi.org/ 10.1016/j.apgeochem.2016.11.008.

Parkhurst, D.L., and Appelo, C.A.J., 2013, Description of input and examples for PHREEQC version 3-A computer program for speciation, batch-reaction, one-dimensional transport, and inverse geochemical calculations: U.S. Geological Survey Techniques and Methods 6-A43, 497 p. accessed February 11, 2019, at https://pubs.usgs.gov/tm/06/ a43/.

Piper, A.M., 1944, A graphic procedure in the geochemical interpretation of water-analyses: Eos, Transactions, American Geophysical Union, v. 25, no. 6, p. 914-923, accessed February 11, 2019, at https://doi.org/10.1029/ TR025i006p00914. 
Prinzhofer, A., Mello, M.R., and Takaki, T., 2000, Geochemical characterization of natural gas: A physical multivariable approach and its applications in maturity and migration estimates: AAPG Bulletin, v. 84, no. 8, p. 1152-1172, accessed February 11, 2019, at https://doi.org/10.1306/ A9673C66-1738-11D7-8645000102C1865D.

Puente, C., 1985, West Virginia ground water resources, in National Water Summary-1984, Hydrologic events, selected water-quality trends, and ground water resources: U.S. Geological Survey Water-Supply Paper 2275, p. 439-446.

Puente, C., and Atkins, J.T., Jr., 1988 Simulation of rainfallrunoff response in small coal mined and undisturbed watersheds in West Virginia: U.S. Geological Survey WaterSupply Paper 2298, 106 p.

R Core Team., 2017, R: A language and environment for statistical computing: Vienna, Austria, R Foundation for Statistical Computing, accessed February 11, 2019, at https:// www.R-project.org/.

Renock, D., Landis, J.D., and Sharma, M. 2016, Reductive weathering of black shale and release of barium during hydraulic fracturing: Applied Geochemistry, v. 65, p. 73-86, accessed February 11, 2019, at https://doi.org/10.1016/ j.apgeochem.2015.11.001.

Revelle, W., 2019, Package 'psych': Procedures for psychological, psychometric, and personality research: Evanston, Illinois, Northwestern University, 445 p., accessed February 11, 2019, at https://cran.r-project.org/web/packages/ psych/psych.pdf.

Révész, K.M., Breen, K.J., Baldassare, A.J., and Burruss, R.C., 2010, Carbon and hydrogen isotopic evidence for the origin of combustible gases in water-supply wells in northcentral Pennsylvania: Applied Geochemistry, v. 25, no. 12, p. 1845-1859, accessed February 11, 2019, at https://doi. org/10.1016/j.apgeochem.2010.09.011.

Schoell, M., 1983, Genetic characterization of natural gases, AAPG Bulletin, v. 67 , no. 12 , p. 2225-2238.

Schoell, M., 1988, Multiple origins of methane in the Earth: Chemical Geology, v. 71, nos. 1-3, p. 1-10, accessed February 11, 2019, at https://doi.org/10.1016/ 0009-2541(88)90101-5.

Sheets, C.J., and Kozar, M.D., 2000, Ground-water quality in the Appalachian Plateaus, Kanawha River Basin, West Virginia: U.S. Geological Survey Water-Resources Investigations Report 99-4269, 25 p.

Stoner, J.D., 1982, Groundwater hydrology and probable hydrologic effects of subsurface mining in southwestern Pennsylvania: Groundwater Monitoring \& Remediation, v. 3, no. 1, p. 128-137.
Taylor, S.W., Lollar, B.S., and Wassenaar, I., 2000, Bacteriogenic ethane in near-surface aquifers: Implications for leaking hydrocarbon well bores: Environmental Science \& Technology, v. 34, no. 22, p. 4727-4732, accessed February 11, 2019, at https://pubs.acs.org/doi/10.1021/es001066x.

Tully, J., 1996, Coal resource regions of the conterminous United States: U.S. Geological Survey Open-File Report 96-279, 2 p.

U.S. Department of Labor, 2018, Hydrogen sulfide: U.S. Department of Labor Occupational Safety and Health Administration web site, accessed February 12, 2018, at https://www.osha.gov/SLTC/hydrogensulfide/hazards.html.

U.S. Environmental Protection Agency, 2019a, Drinking Water Contaminants-Standards and Regulations: U.S. Environmental Protection web site, accessed February 12, 2019, at https://www.epa.gov/dwstandardsregulations.

U.S. Environmental Protection Agency, 2019b, Drinking Water Contaminants-Standards and Regulations for Turbidity, accessed June 7, 2019, at https://safewater.zendesk.com/ hc/en-us/sections/202346167.

U.S. Geological Survey, 1970, The National Atlas of the United States of America: Washington, D.C., U.S. Geological Survey, $417 \mathrm{p}$.

U.S. Geological Survey, 2006, Collection of water samples (ver. 2.0): U.S. Geological Survey Techniques of WaterResources Investigations, book 9, chap. A4, September 2006, accessed February 12, 2018, at http://pubs.water.usgs. gov/twri9A4.

U.S. Geological Survey, 2018a, Water-use data for West Virginia-2015: U.S. Geological Survey National Water Information System database, accessed February 5, 2018, at https://doi.org/10.5066/F7P55KJN. [Site information directly accessible at https://waterdata.usgs.gov/wv/nwis/ water_use/.]

U.S. Geological Survey, 2018b, Water-quality data for West Virginia: U.S. Geological Survey National Water Information System database, accessed February 5, 2018, at https:// doi.org/10.5066/F7P55KJN. [Site information directly accessible at https://waterdata.usgs.gov/wv/nwis/qw.]

West Virginia Geological and Economic Survey, 2019, Coal Bed Mapping Project (CBMP: mapping progress and interactive mapping service for the Coal Bed Mapping Project): West Virginia Geological and Economic Survey, online interactive web service, accessed February 12, 2019, at http://www.wvgs.wvnet.edu/www/coal/cbmp/coalims.html.

White, J.S., and Mathes, M.V., 2006, Dissolved-gas concentrations in ground water in West Virginia, 1997-2005: U.S. Geological Survey Data Series 156, 8 p., accessed February 12, 2019, at https://pubs.usgs.gov/ds/2005/156/. 
Whiticar, M.J., 1999, Carbon and hydrogen isotope systematics of bacterial formation and oxidation of methane: Chemical Geology, v. 161, nos. 1-3, p. 291-314, accessed February 12, 2019, at https://doi.org/10.1016/ S0009-2541(99)00092-3.

Wilde, F.D., Radtke, D.B., Gibs, J., and Iwatsubo, R.T., eds., 2004, with updates through 2009, Processing of water samples (ver. 2.2): U.S. Geological Survey Techniques of Water-Resources Investigations, book 9, chap. A5, April 2004, accessed February 12, 2018, at http://pubs.water.usgs. gov/twri9A5/.

Wyrick, G.G., and Borchers, J.W., 1981, Hydrologic effects of stress-relief fracturing in an Appalachian Valley: U.S. Geological Survey Water-Supply Paper 2177, 51 p.

Yan, B., Stute, M., Panettieri, R.A., Jr., Ross, J., Mailloux, B., Neidell, M.J., Soares, L., Howarth, M., Liu, X., Saberi, P., and Chillrud, S.N., 2017, Association of groundwater constituents with topography and distance to unconventional gas wells in NE Pennsylvania: Science of The Total Environment, v. 577, p. 195-201, accessed February 12, 2019, at https://doi.org/10.1016/j.scitotenv.2016.10.160. 


\section{Appendix 1}

Correlation matrix showing Spearman correlation coefficients of statistical significance at a confidence interval of 99.9 percent for 46 variables, including 41 chemical constituents and 5 principal component analysis scores. 
Appendix 1. Correlation matrix showing Spearman correlation coefficients of statistical significance at a confidence interval of 99.9 percent for 46 variables, including 41 chemical constituents and 5 principal component analysis scores.

[Only values significant at a $=0.001$ shown; --, not significant; PC, principal component; DO, dissolved oxygen; SC, specific conductance; TDS, total dissolved solids; P, phosphorus; N, nitrate]

\begin{tabular}{|c|c|c|c|c|c|c|c|c|c|c|c|c|c|c|c|c|c|c|c|c|c|c|c|}
\hline & Position & 1 & 2 & 3 & 4 & 5 & 6 & 7 & 8 & 9 & 10 & 11 & 12 & 13 & 14 & 15 & 16 & 17 & 18 & 19 & 20 & 21 & 22 \\
\hline 흘 & Variable & $\overline{\underline{L}}$ & ণั่ & 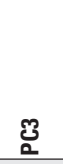 & d্ & 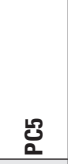 & 옴 & 즘 & 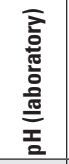 & us & 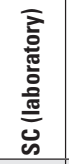 & 足 & 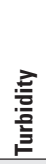 & 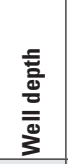 & 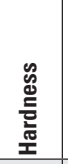 & 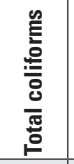 & 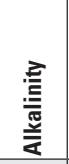 & 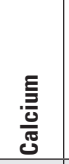 & 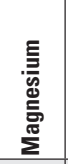 & 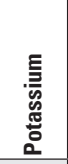 & 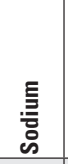 & 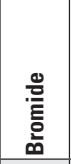 & 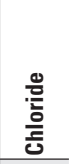 \\
\hline 1 & PC1 & 1 & -- & -- & -- & -- & -0.67 & -- & -- & -- & -- & -- & -- & -- & -- & -- & -- & -- & -- & -0.43 & -- & 0.51 & 0.54 \\
\hline 3 & PC3 & -- & -- & 1 & -- & -- & -- & 0.89 & 0.9 & -- & -- & -- & -- & -- & -- & -- & 0.69 & -- & -- & -- & 0.51 & -- & -- \\
\hline 4 & PC4 & -- & -- & -- & 1 & -- & -0.43 & -- & -- & 0.74 & 0.61 & 0.72 & -- & -- & -- & -- & 0.5 & -- & -- & 0.56 & 0.7 & 0.67 & 0.69 \\
\hline 5 & PC5 & -- & -- & -- & -- & 1 & -- & -- & -- & -- & -- & -- & -- & 0.6 & -- & -0.69 & -- & -- & -- & -- & -- & -- & -- \\
\hline 8 & pH (laboratory) & -- & -- & 0.9 & -- & -- & -- & 0.93 & 1 & 0.45 & 0.43 & 0.47 & -- & -- & -- & -- & 0.71 & -- & -- & -- & 0.55 & -- & -- \\
\hline 9 & sc & -- & 0.49 & -- & 0.74 & -- & -- & 0.47 & 0.45 & 1 & 0.83 & 0.99 & -- & -- & 0.54 & -- & 0.74 & 0.55 & 0.42 & 0.47 & 0.73 & 0.5 & 0.48 \\
\hline 10 & SC (laboratory) & -- & 0.45 & -- & 0.61 & -- & -- & 0.47 & 0.43 & 0.83 & 1 & 0.83 & -- & -- & 0.47 & -- & 0.59 & 0.45 & -- & 0.42 & 0.54 & -- & -- \\
\hline 11 & TDS & -- & 0.51 & -- & 0.72 & -- & -- & 0.49 & 0.47 & 0.99 & 0.83 & 1 & -- & -- & 0.56 & -- & 0.73 & 0.56 & 0.44 & 0.48 & 0.71 & 0.48 & 0.45 \\
\hline 12 & Turbidity & -- & -- & -- & -- & -- & -- & -- & -- & -- & -- & -- & 1 & -- & -- & -- & -- & -- & -- & -- & -- & -- & -- \\
\hline 13 & Well depth & -- & -- & -- & -- & 0.6 & -0.49 & -- & -- & -- & -- & -- & -- & 1 & -- & -- & -- & -- & -- & -- & -- & -- & -- \\
\hline 14 & Hardness & -- & 0.97 & -- & -- & -- & -- & -- & -- & 0.54 & 0.47 & 0.56 & -- & -- & 1 & -- & -- & 0.96 & 0.91 & 0.5 & -- & -- & -- \\
\hline 19 & Potassium & -0.43 & 0.42 & -- & 0.56 & -- & -- & -- & -- & 0.47 & 0.42 & 0.48 & -- & -- & 0.5 & -- & -- & 0.45 & 0.51 & 1 & -- & -- & -- \\
\hline 20 & Sodium & -- & -- & 0.51 & 0.7 & -- & -0.7 & 0.58 & 0.55 & 0.73 & 0.54 & 0.71 & -- & -- & -- & -- & 0.8 & -- & -- & -- & 1 & 0.77 & 0.79 \\
\hline 21 & Bromide & 0.51 & -- & -- & 0.67 & -- & -0.79 & 0.51 & -- & 0.5 & -- & 0.48 & -- & -- & -- & -- & 0.53 & -- & -- & -- & 0.77 & 1 & 0.87 \\
\hline 22 & Chloride & 0.54 & -- & -- & 0.69 & -- & -0.74 & -- & -- & 0.48 & -- & 0.45 & -- & -- & -- & -- & 0.48 & -- & -- & -- & 0.79 & 0.87 & 1 \\
\hline
\end{tabular}


Appendix 1. Correlation matrix showing Spearman correlation coefficients of statistical significance at a confidence interval of 99.9 percent for 46 variables, including 41 chemical constituents and 5 principal component analysis scores. - Continued

[Only values significant at a $=0.001$ shown; --, not significant; PC, principal component; DO, dissolved oxygen; SC, specific conductance; TDS, total dissolved solids; P, phosphorus; $\mathrm{N}$, nitrate]

\begin{tabular}{|c|c|c|c|c|c|c|c|c|c|c|c|c|c|c|c|c|c|c|c|c|c|c|}
\hline & Position & 23 & 24 & 25 & 26 & 27 & 28 & 29 & 30 & 31 & 32 & 33 & 34 & 35 & 36 & 37 & 38 & 39 & 40 & 41 & 42 & 43 \\
\hline 高 & Variable & $\begin{array}{l}\stackrel{ }{\frac{\pi}{2}} \\
\text { 흔 }\end{array}$ & 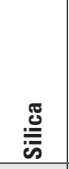 & 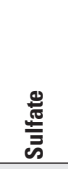 & 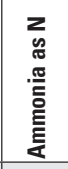 & 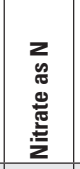 & 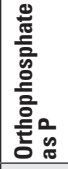 & $\begin{array}{l}\text { 흘 } \\
\underset{\check{c}}{\pi}\end{array}$ & $\begin{array}{l}\text { 壱 } \\
\text { 壹 } \\
\end{array}$ & $\begin{array}{l}\text { 竞 } \\
\text { 窇 } \\
\end{array}$ & 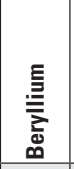 & $\begin{array}{l}\frac{5}{\pi} \\
\overline{0} \\
0\end{array}$ & $\begin{array}{l}\text { むँ } \\
\text { 흥 }\end{array}$ & 흔 & 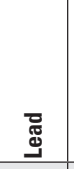 & 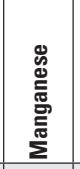 & 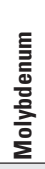 & 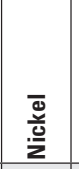 & $\stackrel{\varrho}{N}$ & $\begin{array}{l}\text { 言 } \\
\text { 裹 } \\
\text { 产 }\end{array}$ & 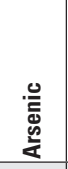 & 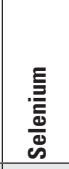 \\
\hline 1 & PC1 & -- & 0.72 & -- & 0.68 & -0.71 & -- & -- & $-0.52 \mid$ & 0.75 & -- & -- & -0.43 & 0.89 & -- & 0.81 & -- & -- & -- & -0.48 & 0.78 & -0.77 \\
\hline 2 & PC2 & -- & -- & 0.67 & -- & -- & -- & -- & 0.63 & -- & -- & -- & -- & -- & -- & -- & -- & -- & -- & 0.43 & -- & 0.44 \\
\hline 3 & PC3 & 0.58 & -- & -0.46 & 0.44 & -- & 0.7 & -- & -- & -- & -0.52 & -0.65 & -0.62 & -- & -0.57 & -- & -- & -0.74 & -0.85 & -- & -- & -- \\
\hline 4 & PC4 & 0.46 & -- & -- & 0.42 & -- & -- & -- & -- & -- & -- & -- & -- & -- & -- & -- & -- & -- & -- & -- & -- & -- \\
\hline 5 & PC5 & 0.42 & -- & -- & -- & -- & -- & -- & -- & -- & -- & -- & -- & -- & -- & -- & -- & -- & -- & -- & -- & -- \\
\hline 6 & DO & -0.5 & -0.51 & 0.62 & -0.86 & 0.75 & -0.53 & -- & 0.52 & -0.71 & -- & -- & 0.57 & -0.69 & -- & -0.52 & -- & 0.55 & -- & 0.51 & -- & 0.79 \\
\hline 7 & $\mathrm{pH}$ & 0.63 & -- & -- & 0.54 & -- & 0.65 & -- & -- & -- & -0.5 & -0.5 & -0.62 & -- & -0.58 & -- & -- & -0.67 & -0.72 & -- & -- & -- \\
\hline 8 & pH (laboratory) & 0.65 & -- & -- & 0.42 & -- & 0.69 & -- & -- & -- & -0.56 & -0.57 & -0.58 & -- & -0.54 & -0.44 & -- & -0.7 & -0.72 & -- & -- & -- \\
\hline 9 & sc & 0.66 & -- & -- & -- & -- & -- & -- & -- & -- & -- & -- & -- & -- & -- & -- & -- & -- & -- & -- & -- & -- \\
\hline 10 & SC (laboratory) & 0.56 & -- & -- & -- & -- & -- & -- & -- & -- & -- & -- & -- & -- & -- & -- & -- & -- & -- & -- & -- & -- \\
\hline 11 & TDS & 0.66 & -- & -- & -- & -- & -- & -- & -- & -- & -- & -- & -- & -- & -- & -- & -- & -- & -- & -- & -- & -- \\
\hline 12 & Turbidity & -- & -- & -- & -- & -- & -- & -- & -- & -- & -- & -- & -- & -- & -- & -- & -- & -- & -- & -- & -- & -- \\
\hline 13 & Well depth & -- & -- & -- & -- & -0.44 & -- & -- & -- & -- & -- & -- & -- & -- & -- & 0.5 & -- & -- & -- & -- & -- & -0.53 \\
\hline 14 & Hardness & -- & -- & 0.58 & -- & -- & -- & -- & 0.55 & -- & -- & -- & -- & -- & -- & -- & -- & -- & -- & 0.45 & -- & 0.44 \\
\hline 15 & Total coliforms & -- & -- & -- & -- & -- & -- & -- & -- & -- & -- & -- & -- & -- & -- & -- & -- & -- & -- & -- & -- & -- \\
\hline 16 & Alkalinity & 0.71 & -- & -- & 0.53 & -- & 0.54 & -- & -- & -- & -0.55 & -0.42 & -- & -- & -- & -- & -- & -0.6 & -0.53 & -- & -- & -- \\
\hline 17 & Calcium & -- & -- & 0.43 & -- & -- & -- & -- & 0.46 & -- & -- & -- & -- & -- & -- & -- & -- & -- & -- & -- & -- & -- \\
\hline 18 & Magnesium & -- & -- & 0.77 & -- & -- & -- & -- & 0.57 & -- & -- & -- & -- & -- & -- & -- & -- & -- & -- & 0.47 & -- & 0.56 \\
\hline 19 & Potassium & -- & -- & -- & -- & 0.52 & -- & -- & -- & -- & -- & -- & -- & -- & -- & -- & -- & -- & -- & -- & -- & 0.54 \\
\hline 20 & Sodium & 0.67 & -- & -0.43 & 0.7 & -0.5 & 0.48 & -- & -- & 0.53 & -- & -- & -0.49 & -- & -- & -- & -- & $-0.64 \mid$ & -0.47 & -- & -- & -0.46 \\
\hline 21 & Bromide & 0.5 & -- & -0.59 & 0.82 & -0.56 & 0.51 & -- & -0.49 & 0.68 & -- & -- & $-0.51 \mid$ & 0.57 & -- & -- & -- & -0.61 & -0.42 & -0.42 & -- & -0.65 \\
\hline 22 & Chloride & -- & -- & -0.55 & 0.75 & -0.49 & 0.42 & -- & -0.48 & 0.69 & -- & -- & -- & 0.53 & -- & -- & -- & -0.58 & -- & -- & -- & -0.61 \\
\hline
\end{tabular}


Appendix 1. Correlation matrix showing Spearman correlation coefficients of statistical significance at a confidence interval of 99.9 percent for 46 variables, including 41 chemical constituents and 5 principal component analysis scores.-Continued

[Only values significant at a $=0.001$ shown; --, not significant; PC, principal component; DO, dissolved oxygen; SC, specific conductance; TDS, total dissolved solids; P, phosphorus; N, nitrate]

\begin{tabular}{|c|c|c|c|c|c|c|c|c|c|c|c|c|c|c|c|c|c|c|c|c|c|c|c|}
\hline & Position & 1 & 2 & 3 & 4 & 5 & 6 & 7 & 8 & 9 & 10 & 11 & 12 & 13 & 14 & 15 & 16 & 17 & 18 & 19 & 20 & 21 & 22 \\
\hline 袬 & Variable & $\bar{d}$ & ণ్ర & শ્ּ & త্రి & 놈 & 옴 & 돌 & 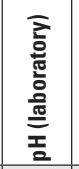 & us & 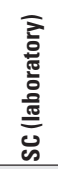 & 吕 & 吾 & 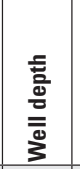 & 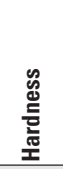 & 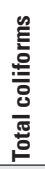 & 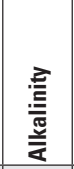 & 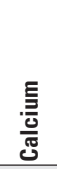 & 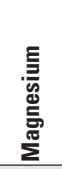 & 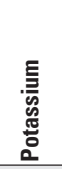 & 吾 & 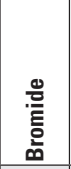 & $\begin{array}{l}\frac{0}{0} \\
\frac{0}{5}\end{array}$ \\
\hline 23 & Fluoride & -- & -- & 0.58 & 0.46 & 0.42 & -0.5 & 0.63 & 0.65 & 0.66 & 0.56 & 0.66 & -- & -- & -- & -- & 0.71 & -- & -- & -- & 0.67 & 0.5 & -- \\
\hline 25 & Sulfate & -- & 0.67 & -0.46 & -- & -- & 0.62 & -- & -- & -- & -- & -- & -- & -- & 0.58 & -- & -- & 0.43 & 0.77 & -- & -0.43 & -0.59 & -0.55 \\
\hline 26 & Ammonia as $\mathbf{N}$ & 0.68 & -- & 0.44 & 0.42 & -- & -0.86 & 0.54 & 0.42 & -- & -- & -- & -- & -- & -- & -- & 0.53 & -- & -- & -- & 0.7 & 0.82 & 0.75 \\
\hline 27 & Nitrate as $\mathbf{N}$ & -0.71 & -- & -- & -- & -- & 0.75 & -- & -- & -- & -- & -- & -- & -0.44 & -- & -- & -- & -- & -- & 0.52 & -0.5 & -0.56 & -0.49 \\
\hline 30 & Uranium & -0.52 & 0.63 & -- & -- & -- & 0.52 & -- & -- & -- & -- & -- & -- & -- & 0.55 & -- & -- & 0.46 & 0.57 & -- & -- & -0.49 & -0.48 \\
\hline 31 & Barium & 0.75 & -- & -- & -- & -- & -0.71 & -- & -- & -- & -- & -- & -- & -- & -- & -- & -- & -- & -- & -- & 0.53 & 0.68 & 0.69 \\
\hline 32 & Beryllium & -- & -- & -0.52 & -- & -- & -- & -0.5 & -0.56 & -- & -- & -- & -- & -- & -- & -- & -0.55 & -- & -- & -- & -- & -- & -- \\
\hline 33 & Cobalt & -- & -- & -0.65 & -- & -- & -- & -0.5 & -0.57 & -- & -- & -- & -- & -- & -- & -- & -0.42 & -- & -- & -- & -- & -- & -- \\
\hline 34 & Copper & -0.43 & -- & $-0.62 \mid$ & -- & -- & 0.57 & -0.62 & -0.58 & -- & -- & -- & -- & -- & -- & -- & -- & -- & -- & -- & -0.49 & -0.51 & -- \\
\hline 35 & Iron & 0.89 & -- & -- & -- & -- & -0.69 & -- & -- & -- & -- & -- & -- & -- & -- & -- & -- & -- & -- & -- & -- & 0.57 & 0.53 \\
\hline 36 & Lead & -- & -- & -0.57 & -- & -- & -- & -0.58 & -0.54 & -- & -- & -- & - & -- & -- & -- & -- & -- & -- & -- & -- & -- & -- \\
\hline 41 & Antimony & -0.48 & 0.43 & -- & -- & -- & 0.51 & -- & -- & -- & -- & -- & -- & -- & 0.45 & -- & -- & -- & 0.47 & -- & -- & -0.42 & -- \\
\hline 42 & Arsenic & 0.78 & -- & -- & -- & -- & -- & -- & -- & -- & -- & -- & -- & -- & -- & -- & -- & -- & -- & -- & -- & -- & -- \\
\hline 43 & Selenium & -0.77 & 0.44 & -- & -- & -- & 0.79 & -- & -- & -- & -- & -- & -- & -0.53 & 0.44 & -- & -- & -- & 0.56 & 0.54 & -0.46 & $-0.65 \mid$ & -0.61 \\
\hline
\end{tabular}


Appendix 1. Correlation matrix showing Spearman correlation coefficients of statistical significance at a confidence interval of 99.9 percent for 46 variables, including 41 chemical constituents and 5 principal component analysis scores.—Continued

[Only values significant at a $=0.001$ shown; --, not significant; PC, principal component; DO, dissolved oxygen; SC, specific conductance; TDS, total dissolved solids; P, phosphorus; N, nitrate]

\begin{tabular}{|c|c|c|c|c|c|c|c|c|c|c|c|c|c|c|c|c|c|c|c|c|c|c|}
\hline & Position & 23 & 24 & 25 & 26 & 27 & 28 & 29 & 30 & 31 & 32 & 33 & 34 & 35 & 36 & 37 & 38 & 39 & 40 & 41 & 42 & 43 \\
\hline 高 & Variable & $\begin{array}{l}\text { 픔 } \\
\text { 흔 }\end{array}$ & 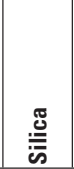 & 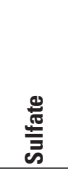 & 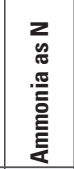 & 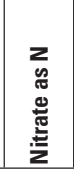 & 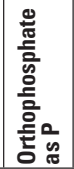 & 흠 & 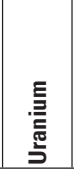 & 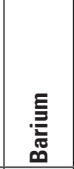 & 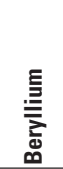 & $\begin{array}{l}\frac{ \pm}{\pi} \\
\text { हैं }\end{array}$ & $\begin{array}{l}\text { む্ } \\
\text { 응 }\end{array}$ & 호 & 胥 & 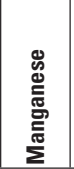 & 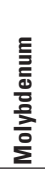 & $\begin{array}{l}\bar{\Phi} \\
\frac{\bar{\omega}}{2}\end{array}$ & $\stackrel{\mathscr{N}}{N}$ & $\begin{array}{l}\text { 言 } \\
\text { 言 } \\
\text { 妾 }\end{array}$ & 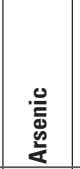 & 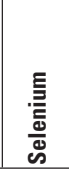 \\
\hline 23 & Fluoride & 1 & -- & -- & 0.53 & -0.43 & 0.6 & -- & -- & -- & -- & -- & -- & -- & -- & -- & -- & -0.52 & $-0.42 \mid$ & -- & -- & -- \\
\hline 24 & Silica & -- & 1 & -- & 0.49 & -0.55 & -- & -- & -- & 0.59 & -- & -- & -- & 0.56 & -- & 0.56 & -- & -- & -- & -0.47 & -- & -0.7 \\
\hline 25 & Sulfate & -- & -- & 1 & -0.59 & 0.55 & -0.56 & -- & 0.56 & -0.59 & -- & -- & 0.48 & -- & -- & -- & -- & 0.62 & 0.48 & -- & -- & 0.69 \\
\hline 26 & Ammonia as $\mathrm{N}$ & 0.53 & 0.49 & -0.59 & 1 & -0.79 & 0.55 & -- & -0.56 & 0.75 & -- & -- & -0.67 & 0.65 & -- & 0.47 & -- & -0.64 & -0.44 & -0.48 & 0.45 & -0.77 \\
\hline 27 & Nitrate as $\mathbf{N}$ & -0.43 & -0.55 & 0.55 & -0.79 & 1 & -- & -- & 0.43 & -0.6 & -- & -- & 0.61 & $-0.67 \mid$ & -- & -0.58 & -- & 0.45 & -- & 0.47 & $-0.44 \mid$ & 0.87 \\
\hline 28 & $\begin{array}{l}\text { Orthophosphate } \\
\text { as P }\end{array}$ & 0.6 & -- & -0.56 & 0.55 & -- & 1 & -- & -- & 0.43 & -- & -0.55 & -- & -- & -- & -- & -- & -0.72 & -0.48 & -- & -- & -- \\
\hline 29 & Radon & -- & -- & -- & -- & -- & -- & 1 & -- & -- & -- & -- & -- & -- & -- & -- & -- & -- & -- & -- & -- & -- \\
\hline 30 & Uranium & -- & -- & 0.56 & -0.56 & 0.43 & -- & -- & 1 & -0.44 & -- & -- & -- & -0.57 & -- & -0.46 & -- & -- & -- & 0.57 & -- & 0.62 \\
\hline 31 & Barium & -- & 0.59 & -0.59 & 0.75 & -0.6 & 0.43 & -- & -0.44 & 1 & -- & -- & -0.49 & 0.58 & -- & 0.47 & -- & -0.5 & -- & -- & 0.47 & -0.69 \\
\hline 32 & Beryllium & -- & -- & -- & -- & -- & -- & -- & -- & -- & 1 & 0.52 & -- & -- & -- & 0.48 & -- & 0.45 & 0.44 & -- & -- & -- \\
\hline 33 & Cobalt & -- & -- & -- & -- & -- & -0.55 & -- & -- & -- & 0.52 & 1 & -- & -- & -- & 0.46 & -- & 0.67 & 0.59 & -- & -- & -- \\
\hline 34 & Copper & -- & -- & 0.48 & -0.67 & 0.61 & -- & -- & -- & -0.49 & -- & -- & 1 & -- & 0.6 & -- & -- & 0.64 & 0.66 & -- & -- & 0.52 \\
\hline 35 & Iron & -- & 0.56 & -- & 0.65 & -0.67 & -- & -- & -0.57 & 0.58 & -- & -- & -- & 1 & -- & 0.82 & -- & -- & -- & -0.57 & $\mid 0.66$ & -0.73 \\
\hline 36 & Lead & -- & -- & -- & -- & -- & -- & -- & -- & -- & -- & -- & 0.6 & -- & 1 & -- & -- & -- & 0.59 & -- & -- & -- \\
\hline 37 & Manganese & -- & 0.56 & -- & 0.47 & -0.58 & -- & -- & -0.46 & 0.47 & 0.48 & 0.46 & -- & 0.82 & -- & 1 & -- & -- & -- & -0.45 & 0.51 & -0.69 \\
\hline 38 & Molybdenum & -- & -- & -- & -- & -- & -- & -- & -- & -- & -- & -- & -- & -- & -- & -- & 1 & -- & -- & -- & -- & -- \\
\hline 39 & Nickel & -0.52 & -- & 0.62 & -0.64 & 0.45 & -0.72 & -- & -- & -0.5 & 0.45 & 0.67 & 0.64 & -- & -- & -- & -- & 1 & 0.73 & -- & -- & 0.48 \\
\hline 40 & Zinc & -0.42 & -- & 0.48 & -0.44 & -- & -0.48 & -- & -- & -- & 0.44 & 0.59 & 0.66 & -- & 0.59 & -- & -- & 0.73 & 1 & -- & -- & -- \\
\hline 41 & Antimony & -- & -0.47 & -- & -0.48 & 0.47 & -- & -- & 0.57 & -- & -- & -- & -- & -0.57 & -- & -0.45 & -- & -- & -- & 1 & -- & 0.63 \\
\hline 42 & Arsenic & -- & -- & -- & 0.45 & -0.44 & -- & -- & -- & 0.47 & -- & -- & -- & 0.66 & -- & 0.51 & -- & -- & -- & -- & 1 & -0.42 \\
\hline 43 & Selenium & -- & -0.7 & 0.69 & -0.77 & 0.87 & -- & -- & 0.62 & $|-0.69|$ & -- & -- & 0.52 & -0.73 & -- & -0.69 & -- & 0.48 & -- & 0.63 & $|-0.42|$ & 1 \\
\hline
\end{tabular}


For additional information, contact:

Director, Virginia/West Virginia Science Center U.S. Geological Survey

11 Dunbar Street

Charleston, WV 25301

or visit our website at: https://www.usgs.gov/centers/va-wv-water

Publishing support provided by the West Trenton Publishing Service Center 


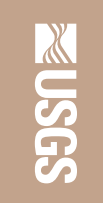

종 